- Networkshop 2019

NWS
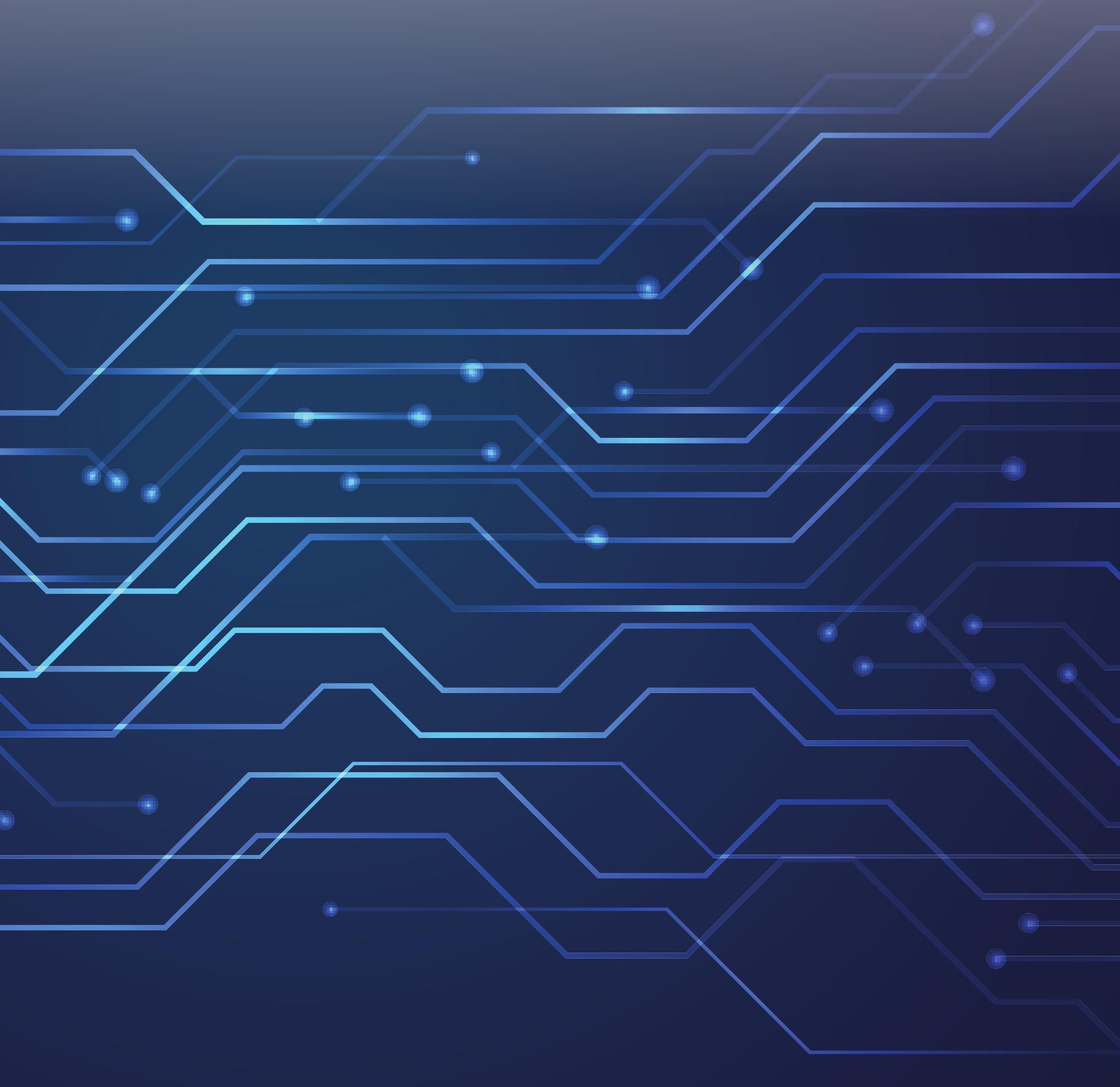

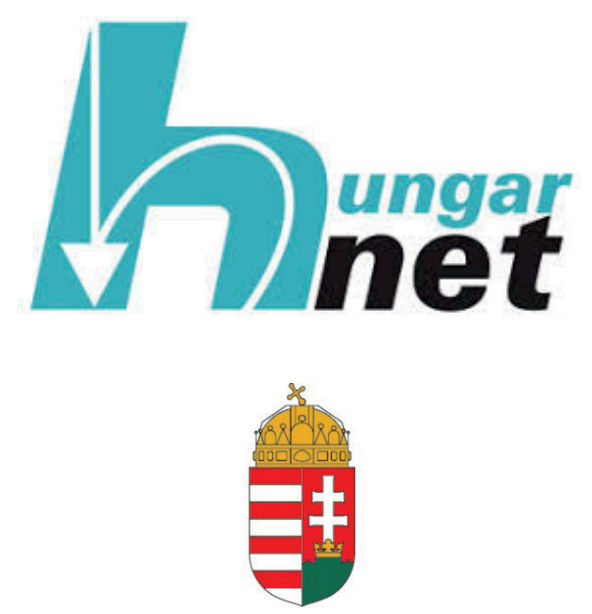

INNOVÁCIÓS ÉS TECHNOLÓGIAI

MINISZTÉRIUM
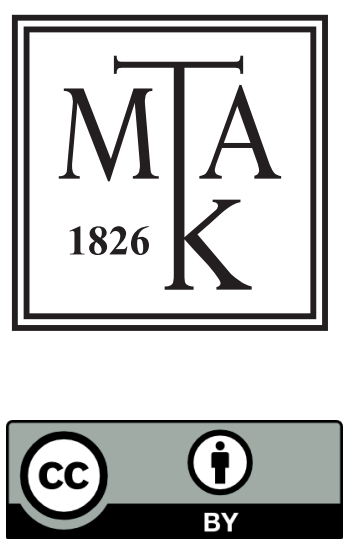

Szerkesztette: Tick József, Kokas Károly, Holl András

Tipográfia és tördelés: Vas Viktória

Networkshop

2019. április 23-26. Széchenyi istván Egyetem, Győr konferencia elöadásainak közleményei

ISBN 978-615-00-7260-9

DOI: $10.31915 / N W S .2019$

Kiadja a HUNGARNET Egyesület

az MTA Könyvtár és Információs Központ közremüködésével

Budapest

2019 


\section{TARTALOMJEGYZÉK}

Elöszó

SMART TECHNOLÓGIÁK, AI, IOT

Berki Borbála: Humán kognitiv jellemzők szerepe a virtuális terek használata során............. 7

Nacsa János - Hajós Mátyás - Komáromi Gergely - Horváth Gergely - Pataki Balázs:

Gömbcsap szerelése ember-robot kollaborációban ........................................................................13

Paniti Imre - Nacsa János - Abai Kristóf:

Robotos szerelési kisérletek háromujjas megfogóval

\section{TARTALOMSZOLGÁLTATÁSOK: KÖNYVTÁRAK, LEVÉLTÁRAK, MÚZEUMOK}

Albert Ágota: GDPR és a köznevelési intézmények

- a GDPR bevezetésének 13+1 lépése a köznevelési intézményekben .....................................31

Bobák Barbara - Gábori Kovács József: Kézírásfelismerés Arany János levelein ..................38

Haász Antal: Áttérés a Primo New User Interface használatára

a Magyar Tudományos Akadémia Könyvtár és Információs Központban ................................45

Holl András - Bilicsi Erika: Nyílt publikálási szoftverek és platformok ...........................................54

Hubay Miklós - Gyuricza Andrea:

Új könyvtári fogalmak gyakorló könyvtárosok szemszögéböl

Juhász Attila - Szabó Dóra: Parazita folyóiratok, a tudományos világ élősködői ....................68

Kovács Béla Lóránt:

Egészségügyi informatikai adatbázisban való szöveges keresés

mesterséges intelligenciával támogatott szemantikus keresővel

Kovács László - Micsik András: MTA SZTAKI DSD

- 25 éve a digitális könyvtárak szolgálatában

Kómár Éva: A múzeumi adatreprezentáció és közzététel formái

a Közgyüjteményi Digitalizálási Stratégia keretében

Lencsés Ákos: A nyílt hozzáférés kérdése a hivatalos statisztikában ...........................................96

Lendvay Miklós: Entitások és kapcsolódások

a könyvtári rendszerekben és azokon túl

Muzs Kriszina - Molnár Tamás - Hoczopán Szabolcs: Open Access pályázati rendszer technikai megvalósítása és a szerzők támogatása a Szegedi Tudományegyetemen

Nagy Dóra - Nagy Gyula:

Haladó funkciók és innovatív fejlesztések az EPrints és Omeka szoftverek körében ....121

Nagy Gyula - Nagy Dóra - Sándor Ákos: Tömeges adatkonverzió és rugalmas export-import lehetőségek az EPrints, OJS és Omeka szoftverek körében ...........................131

Németh Tibor: Magánvállalkozás és közszolgálat: A biográfiai index múfaji megújitása a Magyar Életrajzi Kalauzban

Sütő Péter: Az elektronikus szakirodalmi információforrások hazai lelőhelyadatbázisa, a COMPASS

Szepesi Judit: E-Learning rendszer és elektronikus tananyagfejlesztés

a Könyvtári Intézetben

Ungváry Rudolf: Besorolási, szabványositott, normativ vagy „autorizált” 163

\section{KÖZNEVELÉS, FELSÖOKTATÁS, ELEKTRONIKUS TANULÁSI KÖRNYEZETEK}

Antal Péter: Digitalizáció és sport: az IKT kihivásai a testnevelö képzésben .............................172

Csernai Zoltán: Az informatikai gondolkodás (computational thinking) fogalmi keretei ...181 Leitold Ferenc: A felhasználói viselkedés,

mint információbiztonsági kockázat becslése 
DR. BÁLINT LAJOS (1946-2019) EMLÉKÉRE 


\section{ELőszó}

\section{Tisztelt Olvasó!}

A huszonnyolcadik Networkshop konferenciakötetét ajánljuk szives figyelmébe. Bár a hazai kutatási és felsőoktatási informatikai hálózatot épitő, müködtető és felhasználó szakmai közösség konferenciái hosszú múltra tekintenek vissza, ez a második alkalom, hogy szerkesztett, lektorált tanulmányokból kötetet jelentettünk meg. Minden tanulmány DOI azonositót kapott, és bibliográfiai adataikat az MTMT-ben is rögzítettük. A kötet csak digitális formában kerül terjesztésre - megtalálható lesz az MTA Könyvtár és Információs Központ Open Conference Systems rendszerében, és a REAL-ban - de várhatólag más hazai repozitóriumokban is.

2019-es konferencia 24 elöadása jelenik meg ebben a kötetben - több, mint a tavalyiban, de kevesebb, mint ahány elöadás szerepelt a programban. Köszönjük az Információs és Technológiai Minisztérium támogatását, amellyel a kiadást segitette.

Budapest, 2019

A szerkesztők 
Smart technológiák, AI, loT 
DOI: $10.31915 / N W S .2019 .1$

\title{
Humán kognitív jellemzők szerepe a virtuális terek használata során
}

\author{
Berki Borbála \\ Multidiszciplináris Müszaki Tudományi Doktori Iskola \\ Széchenyi István Egyetem \\ berki.borbala@sze.hu
}

\begin{abstract}
Role of human cognitive characteristics in the use of virtual spaces Virtual realities are used by human beings; thus, their cognitive characteristics are closely related to the user experience. This paper shows the contributing human characteristics and the results of a connecting research about human spatial abilities and the use of virtual realities. For measuring the spatial abilities, the Corsi-test and the mental rotation task were used. Based on the data of 31 people, no significant relationship was found between the measured spatial abilities and the performance on the VR task or the navigational experience. Thus, individual spatial memory and mental rotation skills do not affect the use of this type of desktop VR.
\end{abstract}

Keywords: desktop VR, human cognition, MaxWhere, virtual reality

\section{Bevezetés}

A virtuális valóságokra gyakran egy technológiai termékként gondolunk, amelynél a felhasználói élményt a különbözö újitások és fejlesztések határozzák meg. Azonban mivel ezeket az eszközöket emberek használják, ezért elengedhetetlen a humán jellemzök figyelembevétele. Jelen esetben itt nem klasszikus ergonómiai szempontokat értem, mint például, hogy fizikailag kényelmesen kezelhetö legyen az eszköz, és nem is egy tipikus szoftverergonómiai szempontot, hanem hogy az emberi gondolkodási folyamatokhoz hogyan kapcsolódik egy virtuális tér. Ehhez egy mérést is bemutatok, amely a MaxWhere virtuális valóságban zajlott. Ez egy ún. asztali virtuális valóság, amely a 3D térben elhelyezett okostáblákon jelenít meg weblapokat, dokumentumokat vagy egyéb fájlokat.

\section{Humán kognitív jellemzök és VR}

A kognitiv kifejezés a latin cognosco igéböl származik, jelentése megért, felfog. A megismerési és gondolkodási tevékenységeket jelenti. Ide tartozik az észlelés, figyelem, végrehajtó funkciók, emlékezeti folyamatok, illetve egyéb magasabb rendü gondolkodási feladatok, mint a tervezés, döntéshozás, problémamegoldás. A virtuális terek alkalmazása során a különböző kognitiv funkciók segítenek megérteni a felhasználónak, hogy mi is az a szimuláció, amit látnak, és hogy hogyan tudják használni a teret. Virtuális valóság megismerésekor az alábbi kérdések merülhetnek fel a felhasználóban: elsöként talán az, hogy: mi az, amit látok? Hol vagyok a virtuális valóságon belül, illetve merre tartok, hová megyek? Majd ezután a többi lehetséges cselekvés is sorra kerül. Ehhez elengedhetetlen a pontos észlelés és a figyelem. A virtuális térben való navigálás a perceptuális- 
motoros koordináció megfelelő müködésén alapszik. Emellett a munkamemória, a már meglévő tudásbázis is szerepet játszik a virtuális valóság. ${ }^{1}$

Virtuális valóságok esetében leggyakrabban a téri képességek vizsgálata kerül elötérbe a kognitiv jellemzők közül, hiszen a virtuális valóság térszerüségét a kognitiv funkcióknak köszönhetően tudja megtapasztalni a felhasználó. A téri képességek a kognitiv funkciók és adottságok egy csoportja, amelyek meghatározók a térivizuális információk feldolgozásában. Illetve az olyan problémák megoldása során, ahol téri jellegü információk manipulációjára van szükség.

A virtuális valóságok számos tekintetben különböznek: eltérök lehetnek a navigációs lehetöségek és eszközök, a tér elrendezései, tárgyai, egyszóval komplexsége is különféle lehet; valamint a tér célja, felhasználási módja is sokféle lehet. Ezeket az eltéréseket figyelembe véve, talán nem is olyan meglepö, hogy eltérők a kutatási eredmények a tekintetben, hogy az erősebb vagy a gyengébb téri képességekkel rendelkező felhasználók profitálnak többet a virtuális terek alkalmazásával. Egyes eredmények szerint a téri képességeknek van egy minimális szintje, amely szükséges a résztvevők jó teljesitményéhez a kisérleti feladatban, de ezen szint fölött az eltérő téri képességek nem magyarázzák az eltérő teljesítményeket. ${ }^{2}$

Más kutatások szerint anatómiai modellek tanulásakor a többféle irányból való bemutatás nem segitette, hanem tovább nehezitette a gyengébb téri képességü résztvevők tanulását. ${ }^{3}$ Más kutatási eredmények azonban ennek az ellenkezőjét állitják, vagyis, hogy a rosszabb téri adottságokkal rendelkezök jutottak elönyhöz, ha a virtuális teret használtak a tanulás során. ${ }^{4.5}$

\section{Asztali virtuális valóság}

A virtuális valóság (VR) nemcsak piaci, hanem tudományos szempontból is egyre nagyobb figyelmet kap az utóbbi években. Legtöbb embernek a virtuális valóság szó hallatán a népszerü VR szemüveges megoldások jutnak eszébe, azonban a virtuális valóság megtapasztalásához egy laptop is elegendö lehet. Ebben az esetben kétdimenziós kijelzőn jelenik meg a háromdimenziós virtuális tér. Az ilyen típusú virtuális valóságokat asztali VR-nak (angolul: desktop-VR), vagy nem belemerülő (angolul: non-immersive) virtuális valóságnak nevezik, mivel teljes $360^{\circ}$ helyett, csak a képernyö keretein belül jelenik meg a szimuláció.

\footnotetext{
1 Wickens, C. D., Baker P.: Cognitive Issues in Virtual Reality. In Barfield W., Furness T. A. (szerk.), Virtual environments and advanced interface design. New York, NY, US: Oxford University Press. 1995. 514-541.

2 Modjeska, D., Chignell, M.: Individual differences in exploration using desktop VR, in Journal of the American Society for Information Science and Technology, 2003/54/3. szám, 216-228.

3 Levinson, A. J., Weaver, B., Garside, S., McGinn, H., Norman, G. R.: Virtual reality and brain anatomy: a randomised trial of elearning instructional designs, in Medical Education, 41(5), 495-501

$4 \quad$ Lee, E. A., Wong, K. W.: Learning with Desktop Virtual Reality: Low Spatial Ability Learners Are More Positively Affected, in Computers \& Education, 2014/79. szám, 49-58.

5 Jang, S., Vitale, J. M., Jyung, R. W., Black, J. B.: Direct manipulation is better than passive viewing for learning anatomy in a three-dimensional virtual reality environment, in computers \& Education, 2017/106. szám, 150-165.
} 
Az asztali virtuális valóságok elönye az alacsonyabb eszközigény és hogy nem okoznak szimulációs rosszullétet. Könnyebben kezelhetők, mivel a navigációhoz már ismert eszközöket (egér, billentyüzet) kell használni. Emiatt az oktatás területén is népszerüek ezek a virtuális valóságok, hiszen egy új és látványos felületet biztosít a tudás átadására. Magyarországon például a Széchenyi István Egyetem is alkalmazzák már az oktatás során a MaxWhere ${ }^{6}$ asztali virtuális valóságot. Egy-egy oktatási térben a klasszikus szövegböl és képekböl álló tananyag mellett, helyet kapnak a kapcsolódó videó- és hanganyagok, gyakorló feladatok, vagy akár teljes 3D-modellek is. Továbbá virtuális laboratóriumok is vannak egy-egy ilyen térben, amelyet a hallgatók bármikor elérhetnek, akár otthonról is.7

Tudományos vizsgálatokban is alkalmazták már a MaxWhere virtuális valóságot. Ez alapján hatékonyabban oszhatóak meg segítségével a digitális tananyagok, mint a klasszikus e-learning rendszerekkel (e-mail, Moodle), illetve összetettebb munkafolyamatokat gyorsabban hajtanak végre a felhasználók. ${ }^{8}$ A gyorsaság hátterében az állhat, hogy azonos digitális munkafolyamat végrehajtásához kevesebb felhasználói beavatkozás, illetve gépi müvelet szükséges a virtuális térben, mint klasszikus kétdimenziós interfészeken. ${ }^{9} \mathrm{Az}$ oktatási területen további előny, hogy a közvetlenül 3D térbe beillesztett képekre több felhasználó emlékezett, mint a beillesztett weblapokon megjelenő azonos képekre. ${ }^{10}$

\section{Téri képességek és virtuális valóság kapcsolatának mérése ${ }^{11}$ 3.1. Virtuális tér és a kapcsolódó feladatok}

A teljes kisérlet a MaxWhere virtuális valóságban futott, amely képes megjeleníteni weblapokat, dokumentumokat, képeket, illetve hangfájlokat a háromdimenziós virtuális térben elhelyezett, úgynevezett okostáblákán. Az okostáblák egy 4:3 arányú kijelzőnek felelnek meg, amelyre a korábban felsorolt tartalmak behivhatóak.

A vizsgálat a Glassy elnevezésü térben zajlott, amelyet prezentációs, illetve online kiállitási térnek terveztek. Egy modern, üveg és látszóbeton felületekből álló háromszintes, nyitott épület oldalfalain van elhelyezve 40 okostábla (1. ábra). A résztvevök a legfelső szintröl indulnak, ahol olvashatóak az instrukciók, valamint itt található meg az a weblap, amely végigvezeti öket a feladaton, és ahová a válaszaikat kell beírniuk. A többi okostáblán fényképeket helyeztünk el (forrás: unsplash.com),

\footnotetext{
6 Maxwhere, hozzáférés: 2019.06.25. https://www.maxwhere.com/

7 Budai T., Kuczmann M.: Towards a Modern, Integrated Virtual Laboratory System, in Acta Polytechnica Hungarica, 2018/15/3. szám. 191-204.

8 Lampert B., Pongrácz A., Sipos J., Vehrer A., Horváth I.: MaxWhere VR-Learning Impro ves Effectiveness over Classical Tools of E-learning, in Acta Polytechnica Hungarica, 2018/15/3. szám,125-147.

$9 \quad$ Horváth I., Sudár A.: Factors Contributing to the Enhanced Performance of the MaxWhere 3D VR Platform in the Distribution of Digital Information, in Acta Polytechnica Hungarica. 2018/15/3. szám, 149-173.

10 Berki B.: Better Memory Performance for Images in MaxWhere 3D VR Space than in Website, in Proceedings of the gth IEEE International Conferenc on Cognitive Infocommunications (CoglnfoCom 2018), 281-284. 
amelyeken különböző tárgyak láthatóak semleges háttér elött, néhány esetben feliratok vagy számok. Emellett két okostáblán egy-egy pdf dokumentum volt. A feladat megoldásához a térben kellett mozogniuk, és a digitális tartalmakkal, azok elrendezésével kapcsolatos kérdésekre válaszolniuk. A feladatokkal összesen 12 pontot szerezhettek. A térben való hatékony feladatvégzést a megszerzett pontok száma, valamint az ehhez szükséges idő jelzi. A válaszokat a legfölső szinten elhelyezett kérdöívben kellett rögziteniük, ahová a TAB billentyü megnyomásával visszaugorhattak.

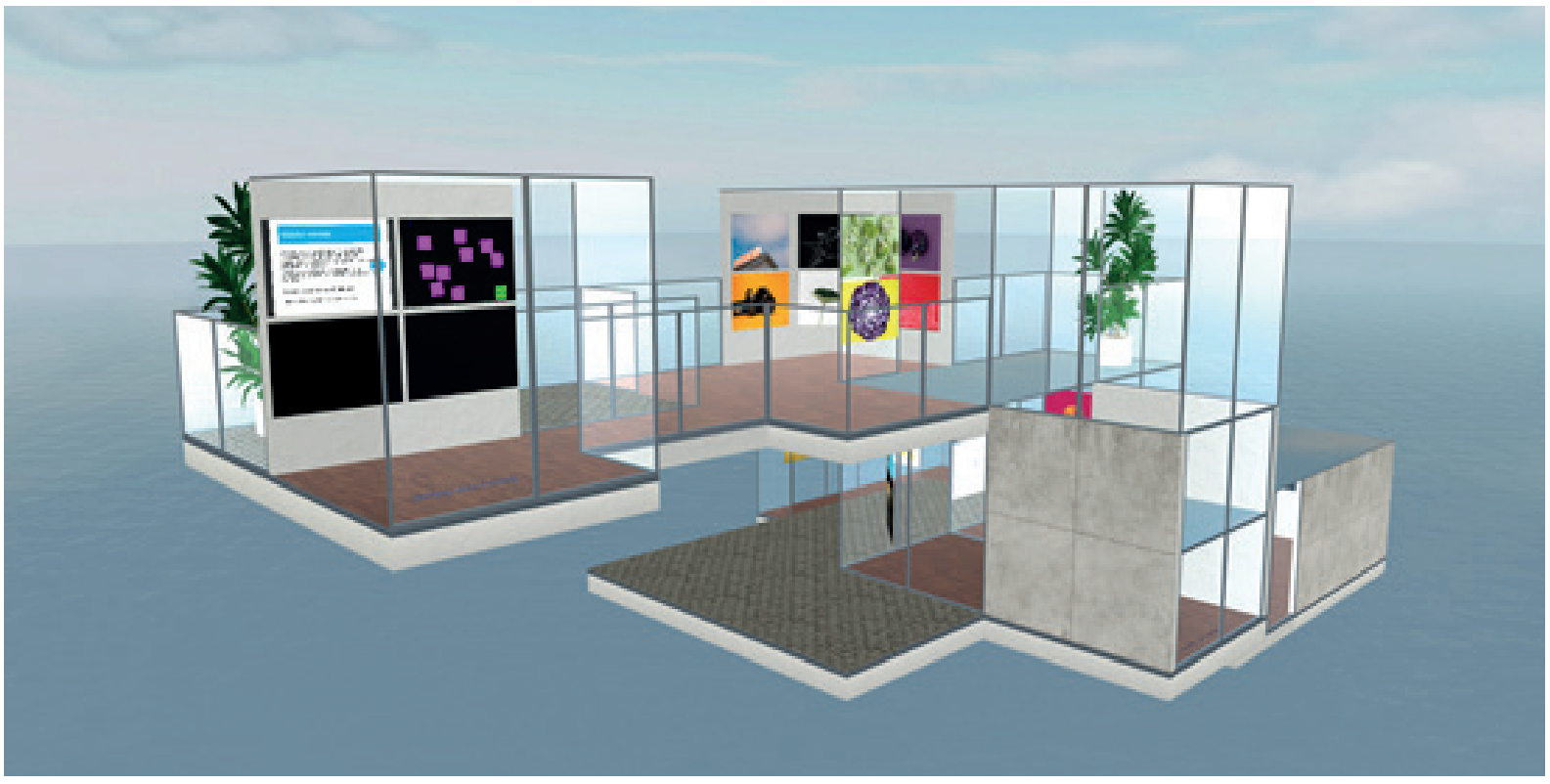

1. ábra: A kutatásban alkalmazott virtuális tér

\subsection{Téri képességmérö eljárások a kutatásban}

A Corsi-tesz $\mathrm{t}^{12}$ a téri információk rövid távú kódolását és megtartását mérő eljárás, amelynek a számitógépes verzióját alkalmaztuk. A képernyön kilenc négyzet látható, amelyek közül néhány egymás után eltérö színben villan fel. A résztvevő feladata, hogy a felvillanás sorrendjében rákattintson a megfelelő négyzetekre. A felvillanó négyzetek száma egyre növekszik a feladat során, amennyiben a kitöltő helyesen válaszolt. Hibázás esetén újra azonos hosszúságú szekvenciát kell megjegyeznie, ha a második sem sikerül, akkor vége a feladatnak, és az utolsó sikeresen megjegyzett szekvencia hossza adja meg a Corsi-terjedelmet.

A mentális forgatás feladat ${ }^{13}$ során egy formának az elforgatott verzióját kell felismerni, két lehetséges ábra közül. A jelen kutatásban egy számitógépes verziót használtam, kétdimenziós ingerekkel. Elöször öt gyakorlófeladatot oldottak meg a résztvevők, majd a teszt során tíz ábrát láttak.

\footnotetext{
12 Corsi, P. M.: Human memory and the medial temporal region of the brain, 1972, Doktori értekezés: McGill University (Kanada)

13 Shepard, R. N., Metzler, J.: Mental Rotation of Three-Dimensional Objects, in Science 1971/171/3972. szám, 701-703.
} 


\subsection{Navigációs élmény mérése}

A résztvevőknek értékelniük kellett a virtuális térben való navigációt, azt, hogy mennyire mozgott magabiztosan a térben, mennyire érezte automatikusnak, természetesnek az irányítást. Ehhez tízes skálán kellett kifejezni az egyetértésüket öt kapcsolódó állítással.

\subsection{Résztvevök és mérés menete}

A vizsgálatban 31 fö vett részt (átlagos életkor 20,5 év; szórás: 3,4). A résztvevők között 25 férfi és 6 nö volt.

A vizsgálat vezetője először röviden szóban ismertette az instrukciókat, amelyeket a résztvevök a virtuális térben is láthattak. A feladatok a virtuális térben egyweboldalon jelentek meg és ott is kellet megadni a válaszokat. Amennyiben a résztvevök kattintással jelezték, hogy részt kivánnak venni a mérésben, akkor elsőként a Corsi feladatot oldották meg, majd a mentális forgatást. Ezután már nem volt szükséges, hogy az okostábla teljes méretben jelenjen meg. Ezután következtek a virtuális térben végzendő feladatok, majd a navigáció szubjektív értékelése és egyéb általános kérdések következtek.

\subsection{Mérés eredményei}

A téri képességek (Corsi-teszt, mentális forgatás) és a hatékonyság (megszerzett pontok) kapcsolatát Spearman-féle rangkorrelációval vizsgáltam. A hipotézisemnek megfelelően a megszerzett pontok nem mutattak szoros együttjárást sem a Corsiterjedelemmel $\left(r_{s}(28)=0.09, p=0.635\right)$, sem a mentális forgatás eredményeivel $\left(r_{s}(29)=-0.174, p=0.351\right)$. Vagyis nem volt szignifikáns kapcsolat a különbözö téri képességek és a 3D virtuális térben végzett feladatok között. A navigációs teljesitmény és a hatékonyság kapcsolatát a Spearman-féle rangkorrelációval vizsgáltam. Azonban hipotézisemmel ellentétben, nem volt szignifikáns kapcsolat a két változó között $\left(r_{s}(29)=0,068, p=0,718\right)$.

\section{4. Összefoglalás}

A fentebb bemutatott kutatás a virtuális térben való feladatvégzés és a kognitiv jellemzők közül a téri képességek kapcsolatának feltárása volt. A vizsgált két téri képességmérő teszt (Corsi-feladat, mentális forgatás) eredményei és a kisérleti feladaton elért pontszám teljesitménye között nem volt statisztikailag szignifikáns kapcsolat, amelyböl arra lehet következtetni, hogy az egyéni téri képességek nem befolyásolják a virtuális térben való feladatvégzést. Ezen eredmények alapján a MaxWhere VR használata elönyös, mivel a térben való hatékony feladatvégzéshez nem szükségesek kiemelkedő téri képességek.

A humán kognitiv jellemzök közül tehát a téri képességeknek nincsen kiemelt szerepe a MaxWhere virtuális valóság használata során.

\section{Köszönetnyilvánítás}

A kutatás az Emberi Erőforrások Minisztériuma ÚNKP-18-3 kódszámú Új Nemzeti Kiválóság Programjának támogatásával készült. 


\section{Bibliográfia}

Berki B.: Better Memory Performance for Images in MaxWhere 3D VR Space than in Website, in Proceedings of the gth IEEE International Conferenc on Cognitive Infocommunications (CoglnfoCom 2018), 281-284.

Berki B.: Kognitiv jellemzők a 3D virtuális terek hatékonyságának hátterében, in Új Nemzeti Kiválóság Program 2018/2019 Tanulmánykötet, 2019, 107-115.

Budai T., Kuczmann M.: Towards a Modern, Integrated Virtual Laboratory System, in Acta Polytechnica Hungarica, 2018/15/3. szám. 191-204.

Corsi, P. M.: Human memory and the medial temporal region of the brain, 1972, Doktori értekezés: McGill University (Kanada).

Horváth I., Sudár A.: Factors Contributing to the Enhanced Performance of the MaxWhere 3D VR Platform in the Distribution of Digital Information, in Acta Polytechnica Hungarica, 2018/15/3. szám, 149-173.

Lampert B., Pongrácz A., Sipos J., Vehrer A., Horváth I.: MaxWhere VR-Learning Improves Effectiveness over Classical Tools of E-learning, in Acta Polytechnica Hungarica, 2018/15/3. szám,125-147.

MaxWhere, hozzáférés: 2019.06.25. https://www.maxwhere.com/

Jang, S., Vitale, J. M., Jyung, R. W., Black, J. B.: Direct manipulation is better than passive viewing for learning anatomy in a three-dimensional virtual reality environment, in Computers \& Education, 2017/106. szám, 150-165.

Lee, E. A., Wong, K. W.: Learning with Desktop Virtual Reality: Low Spatial Ability Learners Are More Positively Affected, in Computers \& Education, 2014/79. szám, 49-58.

Levinson, A. J., Weaver, B., Garside, S., McGinn, H., Norman, G. R.: Virtual reality and brain anatomy: a randomised trial of elearning instructional designs, in Medical Education, 41(5), 495-501.

Modjeska, D., Chignell, M.: Individual differences in exploration using desktop VR, in Journal of the American Society for Information Science and Technology, 2003/54/3. szám, 216-228.

Shepard, R. N., Metzler, J.: Mental Rotation of Three-Dimensional Objects, in Science, 1971/171/3972. szám, 701-703.

Wickens, C. D., Baker P.: Cognitive Issues in Virtual Reality. In Barfield W., Furness T. A. (szerk.), Virtual environments and advanced interface design. New York, NY, US: Oxford University Press. 1995, 514-541. 


\title{
Gömbcsap szerelése ember-robot kollaborációban
}

\author{
Nacsa János ${ }^{1,2}$ \\ 1: Mérnöki és Üzleti Intelligencia Kutatólaboratórium, SZTAKI \\ nacsa.janos@sztaki.hu \\ 2: Jármüipari Kutatóközpont, Széchenyi István Egyetem \\ Hajós Mátyás, Komáromi Gergely, Horváth Gergely \\ Mérnöki és Üzleti Intelligencia Kutatólaboratórium, SZTAKI \\ hajos.matyas | komaromi.gergely | horvath.gergely@sztaki.hu \\ Pataki Balázs \\ Elosztott Rendszerek Osztály, SZTAKI \\ pataki.balazs@sztaki.hu
}

Assembly of ball valve in human-robot collaboration: A ball valve assembly task, as an example, was analysed and solved with a collaborative way, when a cobot and a human operator can work together. A human assistance system (HMIC) was intoduced to lead and help the operator to process the different assembly steps.

\section{Bevezetés}

Az Ipar 4.0 koncepció megjelenése radikálisan megváltoztatta az egész társadalomban az ipari termelésről alkotott képet. A lehetőségek és ígéretek mögötti valóban elérhetö valóság kutatására és a hazai fejlesztések támogatására jött létre a Stratégiai K+F mühelyek kiválósága pályázat keretében az Ipar 4.0 kutatási és innovációs kiválósági központ, melynek megvalósulási helyszíne a SZTAKI györi telephelye, amely a Széchenyi Egyetem területén müködik. A kiválósági központban a megcélzott eredmények három pontban foglalhatók össze:

- Az 14.0 elveinek, a kiber-fizikai gyártórendszer paradigma háttértechnológiáinak kutatása.

- Egyetemi és ipari oktatás, tesztkörnyezet létrehozása ötletek kipróbálására, problémák feltárására.

- $\quad$ 4.0 szakértői támogatást igénylő ipari megbizások vállalása és teljesítése.

A háromféle és egymást kiegészitve erősitő eredményt az alábbi kutatási területekre összpontositva reméljük elérni:

- Szituáció-tudatos, erőforrás-hatékony és robusztus termeléstervezés és irányítás.

- Kooperativ és adaptív termelési és logisztikai hálózatok tervezése és müködtetése.

- Robusztus kooperatív kontrol kiber-fizikai rendszerekben.

- $\quad 14.0$ megoldások az energia-hatékony és fenntartható gyártás támogatására.

- Számítási felhő alapú termelésinformatikai szolgáltatások.

- 14.0 megoldásokat használó, demonstrációs mini gyártó- és logisztikai rendszer létrehozása. 
Jelen dolgozat az utolsó pontként említett mintarendszer egyik első eredményét ismerteti. Pontosabban a mintarendszer három fókuszából (kiber-fizikai gyártó rendszer, digitális iker és kollaborativ robotos szerelés) a legutolsóban született megoldást mutatja be: egy általánosan használt alkatrész, az egy colos gömbcsap szerelésének kollaboratív megoldását.

\section{Kollaboratív robotos szerelés}

A robotos szerelés és általában az ipari robotok használata olyan környezetben valósul meg a mai napig, ahol a gyorsan mozgó robot egy körültekintően lehatárolt térben dolgozik, ahova ember nem léphet be, amikor a robot mozog. Hagyományosan mechanikusan lezárt tereket képeznek (pl. fémketrecek) vagy speciális mozgásérzékelökkel (pl. lézerfüggönyökkel) biztositják, hogy a mozgó robot és az ember ne kerüljön közel egymáshoz.

Ugyanakkor egyre több olyan feladat kerül megfogalmazásra, ahol a robot és az ember közös munkája sok előnnyel kecsegtet. Pl. egy nehezebb alkatrész pontos elhelyezése, majd rögzítése soránjó, ha egy robot tartja az alkatrészt, az ember pedig finom pici mozgásokkal tudja a helyére pozícionálni. Általában fogalmazódik meg az igény az emberi rugalmasság és problémamegoldó képesség kombinálására a robot precizitásával, kitartásával és akár erejével.

A lehetöség megteremtése azonban rögtön sokféle problémát felvet, amit röviden úgy lehetne jellemezni, hogyan lehet biztonságos, félelmek nélküli munkakörnyezetet megvalósítani. Részletezve ez a robottal dolgozó ember szempontjából azt jelenti, hogy:

- a robot olyan pályán mozog, amire az ember számít: „tudom, hogy mit fog csinálni"

- a robot felismeri az ember tevékenységét: „tudom, hogy érzékel engem”

Ez a két egyszerünek tünő elvárás megvalósitandó müszaki feladattá átfogalmazva komoly kihívásokat jelent, melyek közül a legfontosabbak az alábbiak:

- intuitiv ember-robot interfész,

- érzékelés dinamikusan változó környezetben,

- adaptivitás a robot vezérlésében,

- interoperabilitás,

- elegendően pontos modellezés és szimuláció.

Érdemes megemliteni, hogy ezek az elvárások nagyon sokféle szabványban (EN ISO 12100, EN ISO 13949-1/2, EN 60204-1, EN 62061, EN ISO 10218, ISO/PDTS 15066, ISO 10075-1, ISO 26000 stb.) is megfogalmazódnak, melyeket meglehetősen nehéz maradéktalanul teljesíteni [1],[2].

\section{A kollaboratív szerelési környezet}

A szerelési környezet (1. ábra) központi eleme a robot, mely egy mobil állványon áll. Az állvány súlya olyan, hogy biztositja, hogy a robot bázisa ne mozdulhasson el. A robot ill. az állvány köré több szerelő asztal helyezhető el, amely biztositja hogy (1) egyidöben több helyen levö palettáról lehessen szerelni vagy (2) többféle szerelési feladathoz szükséges munkakörnyezetet lehessen kialakitani. Az asztalok 
lábain olyan kerekek vannak, amelyeket fel lehet emelni és akkor az asztal fixen megáll, ráadásul az asztalok egymáshoz és a robotállványhoz oldható kötéssel vannak összeépitve. A kialakitás elönye, hogy egyszerüen átépithető, egy robot környezete könnyedén megváltoztatható, de kb. egy nap alatt a teljes 14.0 labor munkahelyeinek az elhelyezése átkonfigurálható.

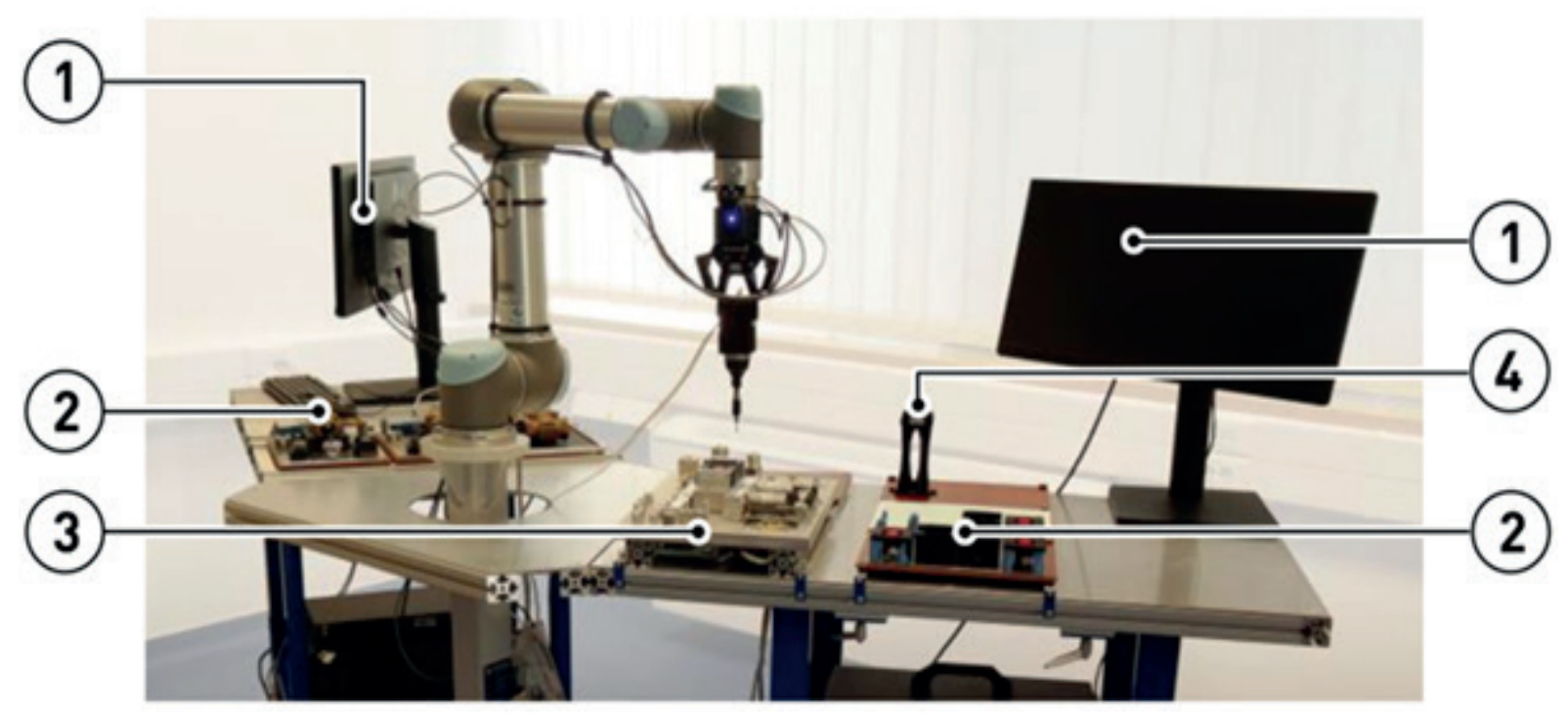

1. ábra A gömbcsap szerelés robotos környezete

Az asztalok alatti tálcákon helyezkednek el a szerelési környezet IT eröforrásai a robotvezérlő és egy számítógép, amely biztosítja az ember és a robot valamint a teljes rendszer és a laborszintü vezérlés MESS [4| közötti kapcsolatot. Az emberrel sokféle módon képes a rendszer kommunikálni (4. fejezet), de különösen a fejlesztéskor a hagyományos monitorok (1) az elsődlegesek. A szerelendő munkadarabok ún. palettákon (2) találhatók, melyeken az alkatrészek strukturáltan, szerelésre előkészitve találhatók. A palettákat mobilrobot (AGV) vagy operátor szállitja a munkahelyre és lyuk-csap illesztéssel kerülnek pontos pozícióba vagy a robot vagy az ember közremüködésével. A szerelési készüléket (3) kézzel kell átállitani (megfelelö ülékek ki/be szerelésével, pozicionálásával), hogy alkalmas legyen pl. az egy colos gömbcsap szerelésére. A legtöbb szerelési lépés a robot megfogójával végrehajtható, kivéve a csavarozás, amikor egy csavarozó szerszámot kell a robotnak megfognia. A speciálisan tervezett szerszám egy rögzített állványon (4) található, innen veszi fel a robot, amikor a csavarozás következik.

\section{Az egy colos gömbcsap szerelési modellje}

A gömbcsap, amely alapvetöen egy egyszerü tárgy, összesen 13 alkatrészböl áll, melyek sok szempontból különböznek: müanyag - fém, alaktartó - alakváltozó; speciális elem - tömeg alkatrész stb. A 2. ábra bal felén a gömbcsap egy ún. „robbantott alkatrészrajza látható”, míg a jobb oldalon a gráf mutatja az egyes alkatrészek kapcsolódását (vastag vonalak). Látható az ábrán, hogy a négy csavar egymással felcserélhetö, hogy melyiket melyik menetbe csavarjuk be a fedélen. Elméleti módszerek is léteznek [5] az összeállitott CAD modellböl közel 
automatikusan generálni a szerelési sorrendtervet, a gömbcsap esetében ez a módszer ellenőrzésre szolgált és ugyanazt eredményezte, mint a szerzők által kialakitott sorrend. Fontos megjegyezni, hogy a robotos szerelés nem lett volna lehetséges, ha a robot megfogójának a pofájába nem került volna egy speciális profilú elem, melynek segítségével a robot megbízhatóan fel tudta venni a kisebbik O gyürüt. Az eredeti - univerzálisabb - elem ezzel nem boldogult.

A szerelés lépéseinek a programozásánál több olyan mikro operációt is be kellett építeni a robot programba, amelyet az elméleti modellböl nem lehetséges meghatározni. Pl. a fröccsöntött müanyag tömítések méretének szórása miatt a fedélbe helyezett tömitésekkel körülvett gömböt kétféleképpen is „meg kellett nyomni", hogy biztosan belekerüljön a tömités pereme a fedélen erre a célra kialakitott vájatba. A kézi szerelések is azt mutatták, hogy ugyanezzel a problémával az ember is gyakran találkozott.
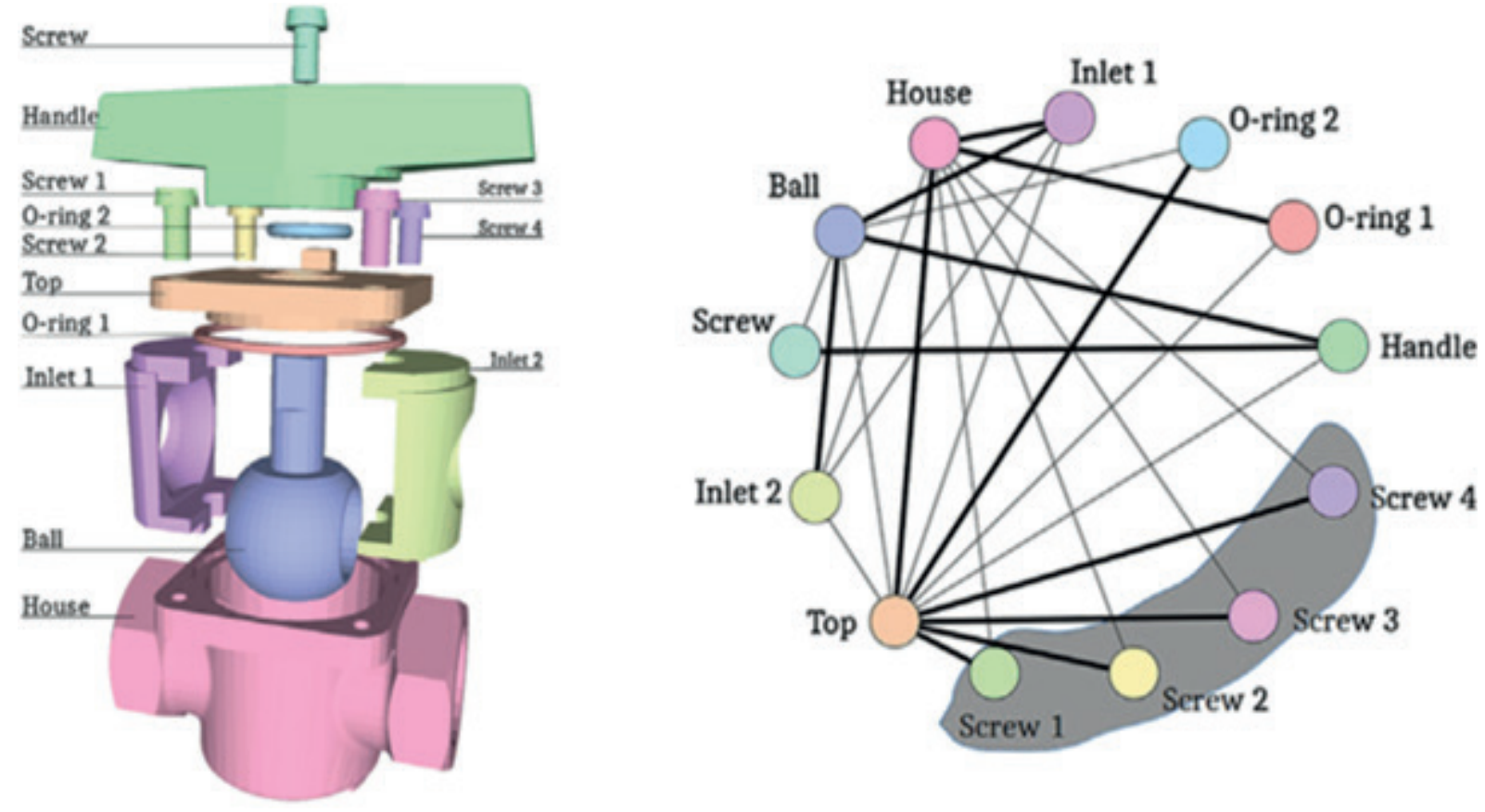

2. ábra A gömbcsap alkatrészei és szerelési kapcsolatuk

\section{Multi-modális kommunikáció a robot és az ember között}

Ipari környezetben valamilyen IT eszköz (pl. számítógép) vagy gép (pl. robot) és az ember közötti kommunikációt hagyományosan monitor és billentyüzet/egér eszközökkel valósitják meg. A multimodális kommunikáció arra szolgál, hogy kiszélesitse a lehetséges kommunikációs csatornákat, hogy mindig azon a csatornán és abban a formában kommunikáljon az ember és a gép, amely az adott feladathoz és környezethez, sőt az adott emberhez a leginkább megfelelö. Rögtön a vizuális megjelenités formája lehet többféle - például szöveg, kép, videó, virtuális valóság, kiterjesztett valóság stb. - de más módon is közölhetünk információkat az emberrel (beszédszerü hang, speciális fényjelzés, hangeffektusok, rezgés a telefonon stb.) Még nagyobb a skála, hogy az ember hogyan küldhet üzeneteket: a billentyü, 
egér, a napjainkban igen elterjedt érintőképernyő mellett szóban elmondott parancsokkal, különféle nyomógombokkal (pl. vészstop), de akár testhelyzetével, kar vagy kézmozdulataival.

Ugyanilyen fontos a kommunikáció tartalma is, ami sokkal többet jelent, mint pl. az üzenet nyelve. Más információra van szüksége egy gyakorlott szakembernek, mint egy kezdönek vagy egy frissen a feladathoz állitott munkásnak. Egy fiatalabb ember általában jobban érti a vizuális jelzéseket, míg az idösebbek inkább a szöveges magyarázatokhoz vannak hozzászokva. Van, aki igényli, hogy sok ellenörzési pont legyen, mert ez megnyugtatja, mig másokat ezek inkább idegesitenek. Olyan eszközre van szükség, amelyben ez a sokféle kommunikációs csatorna és igény egyszerüen konfigurálva megvalósitható.

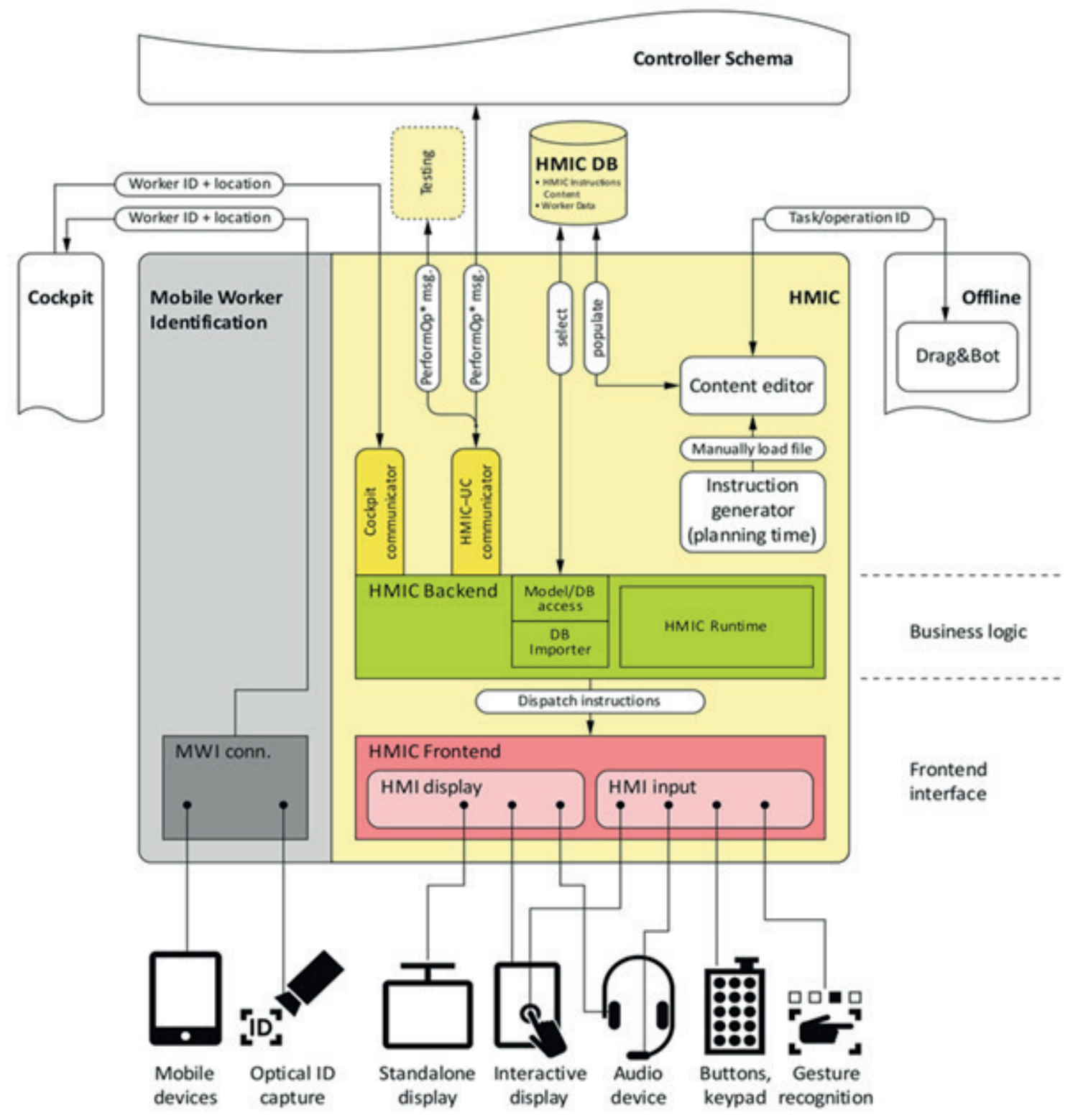

3. ábra Sematikus ábra a HMIC architektúrájáról 


\section{HMIC}

Szerelés közben a felhasználót utasitásokkal kivánjuk ellátni, de nem szeretnénk korlátozni magunkat abban, hogy erre milyen eszközt használjunk. Az elöző fejezetben bemutatott eszközök egységes kezelése érdekében kidolgozásra került a Human Machine Interface Controller (HMIC) [3]. Elvárás, hogy a kommunikáció kétirányú legyen, tehát felhasználói beavatkozásra is legyen lehetőség. Mivel nincs szükség arra, hogy a felhasználó által használt eszköz komplex logikát implementáljon, ezért logikus döntésnek bizonyult a szerver-kliens megvalósitás és a népszerü és széles körben elterjedt sztenderdek használata (például HTML5). Ez lehetőséget biztosit arra, hogy a megjelenítő eszközök flexibilisen változtathatók legyenek, illetve tetszöleges új eszközt használhassunk. A rendszer eredetileg egy komplex rendszer részeként készült, igy fel lett készítve külsö komponensekkel való kommunikációra, szabványositott interfészen keresztül. Ennek részleteit a 3. ábra szemlélteti.

\section{Kollaboratív gömbcsap szerelés állapotgépi leírása}

A szerelés sok apró lépése öt komplex müveletbe lett összevonva. Ezek a lépések, bár különböző komplexitásúak, a tapasztalatok szerint minden operátor számára érthetö feladatokat jelentenek:

- A gömb és a tömítések összeállitása.

- A szükséges két O gyürü felhelyezése a fedélre.

- A ház összeállitása, amikor először a fedél közepén levő lyukba kell helyezni az első lépésben összeállitott gömböt a tömitésekkel együtt, majd az egészre rányomni a házat.

- A fogantyú ráhelyezése a házra.

- A fedél és a ház összecsavarozása, valamint a fogantyú csavarozása.

Az elsö két müvelet a strukturált palettán történik, a harmadik a szerelési készülék egy külön területén, melyet megfelelö ülékek szolgálnak. Illetve a müvelet végén a házat megfordítva a készülék satujába kerül a munkadarab. Itt kerül rá a negyedik lépésben a fogantyú illetve történik a csavarozás.

Mindegyik szerelési müveletet a kollaboratív környezetben az operátor is és a robot is végre tudja hajtani, ugyanakkor a müveletek közötti ellenörzést azonban csak az ember, amely feladatok elsősorban a robot müveletei miatt szükségesek, de fel kell készülni képzetlen és így gyakorlatlan operátor támogatására is. Ezekböl a megfontolásokból alakult ki az alábbi állapotgépi leírás, ahol soronként kell végrehajtani a müveleteket: 


\begin{tabular}{|l|l|l|}
\hline Feladat & Emberi müvelet & Robot müvelet \\
\hline Kiindulási feltételek ellenörzése & O1_C & \\
\hline $\begin{array}{l}\text { A gömb és a tömítések } \\
\text { osszeállítása }\end{array}$ & O2_M & O2_R \\
\hline A gömb tömités ellenörzése & O2_C & \\
\hline O gyürük fedélbe helyezése & O3_M & O3_R \\
\hline $\begin{array}{l}\text { Fedélben levő O gyürük } \\
\text { ellenörzése }\end{array}$ & O3_C & \\
\hline Ház összeállitása & O4_M & O4_R \\
\hline Az összeállitott ház ellenörzése & O4_C & \\
\hline Fogantyú felhelyezése & O5_M & O5_R \\
\hline Az fogantyús ház ellenörzése & O5_C & \\
\hline Csavarozás & O6_M & O6_R \\
\hline A kész gömbcsap ellenörzése & O6_C & \\
\hline Hiba & O0_X & \\
\hline
\end{tabular}

Az állapotleírásban az utolsó sor kivételt jelent, hiszen ide akkor ugrik a vezérlés, ha valahol hiba történt. Ekkor a félig kész alkatrészt eltávolítva a szerelési készülékböl és palettát cserélve egy új munkadarab szerelése kezdhető meg.

\section{Az operátor támogatása a HMIC környezetben}

Az állapotleirás nyomán készülhetett el az operátor munkáját segítő rendszer, amely - valós ipari tesztek (Volvo, Aciturri) tapasztalatai [6] alapján a szöveges információ mellett videót vagy képet tartalmaz. Az ellenörzési pontokon az operátor két képet lát a szöveg mellett: az alkatrészek palettáját és a szerelési készüléket, mindkettőt abban az állapotban, ahogy az adott ponton ki kell nézniük. Az emberi szerelés választása esetén a feladat ismertetése mellett egy többször is megtekinthető videó mutatja a tennivalót. A robotos szerelés választásakor látható, hogy a robot hogyan végzi el a szerelési lépést (egy korábbi felvétel), majd a szerelés végeztével a rendszer tovább lép a következő - ellenörzési - lépésre (4. ábra). 


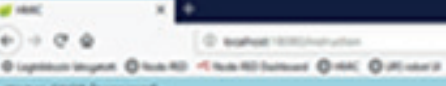

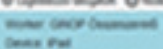

contsons

0.03 .49 .98

A robot a nagy $O$ gyürüt az fedélre helyezi, majd behelyezi a kis $\mathbf{O}$ gyürüt is. A szerelési mũvelete videón is megtekinthetō. Az összeállitott elem a fedél eredeti helyén várja a szerelés folytatását. Ha inditja szerelést lépjen hátra, amig a robot szerel, semmiképpen se avatkozzon közbe, amig a robot vissza nem tér jelenlegi pozíciójába!

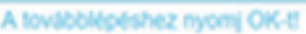

4. ábra A 02_R müvelet a HMIC-ben

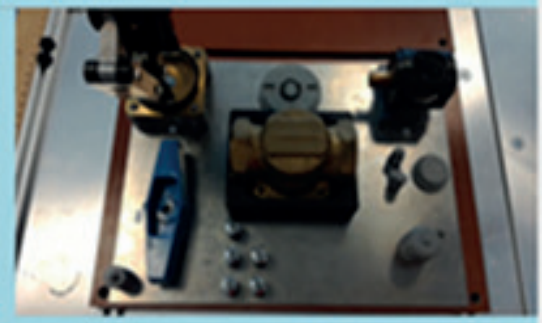

\section{Köszönetnyilvánítás}

A bemutatott kutatás „|par 4.0 kutatási és innovációs kiválósági központ" projekt (GINOP-2.3.2-15-2016-00002) keretében valósult meg, és az EU Horizon 2020-as EPIC projektje (No. 739592) is támogatta, mivel bekerült a projekt esettanulmányai közé.

\section{Összegzés}

Kollaboratív szerelési munkakörnyezetben, amely az Ipar 4.0 kutatások egyik fókusza, egy kisérleti rendszer került ismertetésre, ahol az egy colos gömbcsapot robot és/vagy ember szereli össze 5 lépésben. Röviden bemutatásra került az együttmüködést biztositó HMIC rendszer is.

\section{Hivatkozások}

[1] Zsolt Kemény, Richárd Beregi, János Nacsa, Csaba Kardos, Dániel Horváth: Example of a problem-to-course life cycle in layout and process planning at the MTA SZTAKI learning factories; 9th Conference on Learning Factories 2019

[2] L. Wang, R. Gao, J. Váncza, J. Krüger, X.V. Wang, S. Makris, G. Chryssolouris: Symbiotic humanrobot collaborative assembly; CIRP Annals -- Manufacturing Technology, Vol. 68. No. 2. (2019)

[3] Cs. Kardos, Zs. Kemény, A. Kovács, B. E. Pataki, J. Váncza: Context-dependent multimodal communication in human-robot collaboration; 51st CIRP Conference on Manufacturing Systems, Procedia CIRP 72 (2018) p. 15-20 
[4] Pedone Gianfranco, Beregi Richárd, Erdös Gábor: Manufacturing Execution and Support System (MESS) for Future Intelligent Factory Architecture (FIFA), Functional Specification, Kutatási jelentés (IPAR 4.0 Kutatási és Innovációs Kiválósági Központ, GINOP-2.3.2-15-2016-00002), SZTAKI, 2018

[5] Kardos, Cs., Kovács, A., Váncza, J.: Decomposition approach to optimal feature-based assembly planning. CIRP Annals - Manufacturing Technology, 66(1), 2017

[6] SYMBIO-TIC Final Video

http://Www.symbio-tic.eu/index.php?option=com_k2\&view=item\&id=734:symbio-tic-finalvideo\&ltemid $=33$ 


\title{
Robotos szerelési kísérletek háromujjas megfogóval
}

\author{
Paniti Imre ${ }^{1,2}$, Nacsa János ${ }^{1,2}$, Abai Kristóf ${ }^{1,2}$ \\ 1: Termelésinformatikai és Termelésirányitási Kiválósági Központ (EPIC), \\ Számitástechnikai és Automatizálási Kutatóintézet (SZTAKI), \\ 2: Jármüipari Kutatóközpont (JKK), Széchenyi István Egyetem (SZE) \\ paniti.imre@sztaki.hu, nacsa.janos@sztaki.hu, abai.kristof@sztaki.hu
}

\section{Robotic assembly experiments with three-finger gripper}

The article introduces a collaborative workspace built around the Industry 4.0 Sample System with a Collaborative Robot (a so called Cobot) using a 3-finger gripper. It describes in detail the developments that allow independent movement of the 3 fingers. It shows what kind of force sensors are used in the system and the capabilities of them. The Virtual Reality (VR) model of the system is also presented, where the model follows the movements of the system in real-time by continuously reading the Kinect sensor (RGB camera and depth sensor) input and the joint coordinates of the robot. Finally, three demonstration applications are described.

Keywords: Robotised assembly, Industry 4.0, VR modelling

\section{Bevezetés}

Az ipar folyamatos fejlödésének köszönhetöen az elterjedt és széles körben alkalmazott technológiák kereteit lassan kinőtték az egyre növekvő és szerteágazó igények. Ezek a változások olyan jelentősek, hogy új ipari korszaknak tekinthető ezek bevezetése, igy joggal mondhatjuk, hogy napjainkban is zajlik a negyedik ipari forradalom, vagy ismertebb szóhasználattal élve, az Ipar 4.0 korát éljük. Ez az átalakulás jól szemléltethető az 1. ábrán látható virtuális és fizikai világ konvergenciájával.
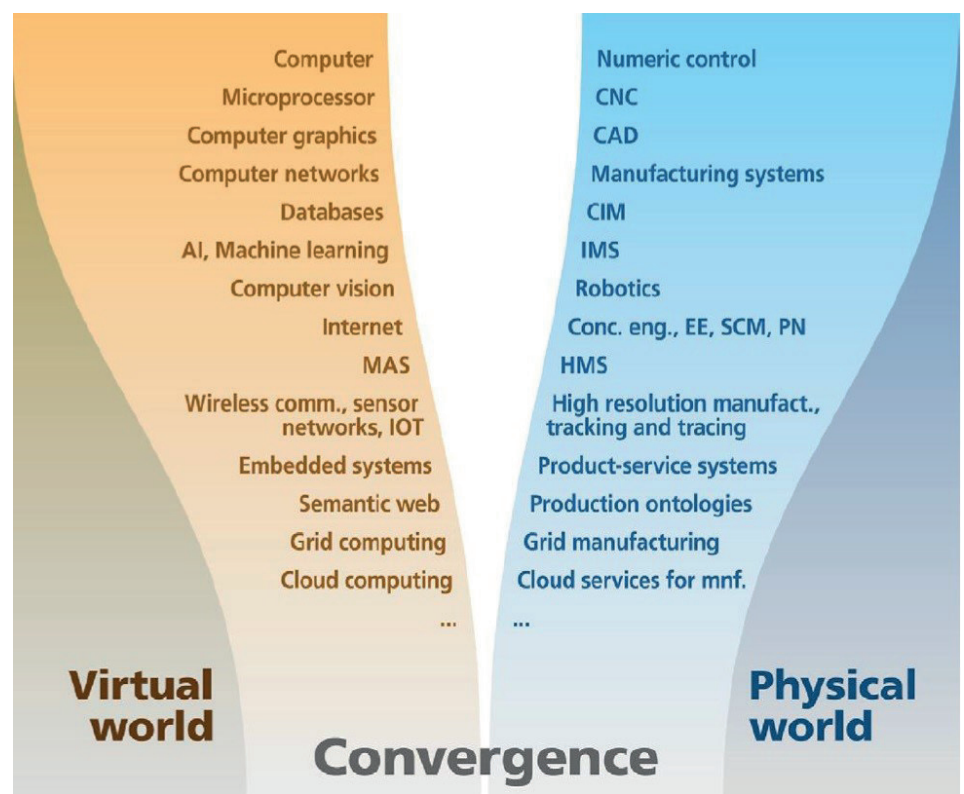

Virtual world

\section{Convergence}

world

1. ábra: A virtuális és fizikai világ konvergenciája [1] 
Mivel rengeteg kérdés merül fel az új technológiákkal kapcsolatban, és számos még megoldásra váró feladat áll elöttünk, szükségét láttuk egy olyan laboratórium létrehozásának, melyben megépithető egy olyan kis ipari környezet, egy mintarendszer, melyben lehetőség van az újitások kipróbálására, tesztelésére, összetettebb rendszerek tervezésére és implementálására, illetve lehetöség van új felmerülő problémák megoldására és a megoldások bemutatására is. Ezen felül a rendszer az oktatásban is jelentős szerepet vállalhat, lehetőséget nyújt arra, hogy a hallgatók, már az egyetemi tanulmányaik alatt megismerhessék a fejlődési irányokat, találkozzanak az új technológiákkal.

A 4. Ipari forradalom magába foglalja a robotok fejlődését is, igy a hagyományos ipari robotok mellett megjelentek a könnyüsúlyú kollaborativ (együttmüködö) robotok, amelyek mozgásától már nem kell megvédeni az embereket különböző ipari biztonságtechnikai eszközökkel, mivel felépítésükböl és vezérlésükből adódóan nem árthatnak különösebben az azokkal kapcsolatba kerülöknek.

A Fraunhofer Institute for Industrial Engineering (FhG IAO) készitett egy tanulmányt [2], melyben arra mutat rá, hogy az ember-robot együttmüködés hatékonyan alkalmazható, az automatizált és tisztán humán munkaerőt foglalkoztató termelésben is. A tanulmány célja továbbá az volt, hogy megmutassa a kis- és középvállalatoknak, hogy a könnyüsúlyú robotok alkalmazása számukra is megtérülö beruházás lehet, növelheti a termelékenységet még abban az esetben is, ha kis sorozatnagyságokat gyártanak nagyszámú termékváltozat mellett. Az eddigi nagy beruházást igénylő automatizálás most a relatív olcsó könnyűsúlyú robotoknak köszönhetöen nemcsak a nagyvállalatok privilégiuma.

A felmérésben feltárták, hogy a cégek miért választották az adott alkalmazás tervezésekor, a könnyüsúlyú robotok alkalmazását, azember-robot együttmüködést (2. ábra). A megkérdezett vállalatok $80 \%$-a számított arra, hogy ezzel a beruházással hatékonyabb lesz a termelés. Sok cég innovációs céllal fogott bele a kollaborativ munkavégzésbe, és a cégek több mint felénélszempont volt az ergonómia növelése, ezzel a dolgozók munkájának kényelmesebbé és biztonságosabbá tétele. Ezen kivül még sok más indokot felsoroltak a gyártók, mint például az összeszerelési idő csökkentése, monotonitás csökkentése, rugalmasság növelése.

A 3. ábrán látható, hogy a felmérésben szereplő alkalmazásokban milyen típusú múvelet végrehajtására alkalmazták a robotokat. 


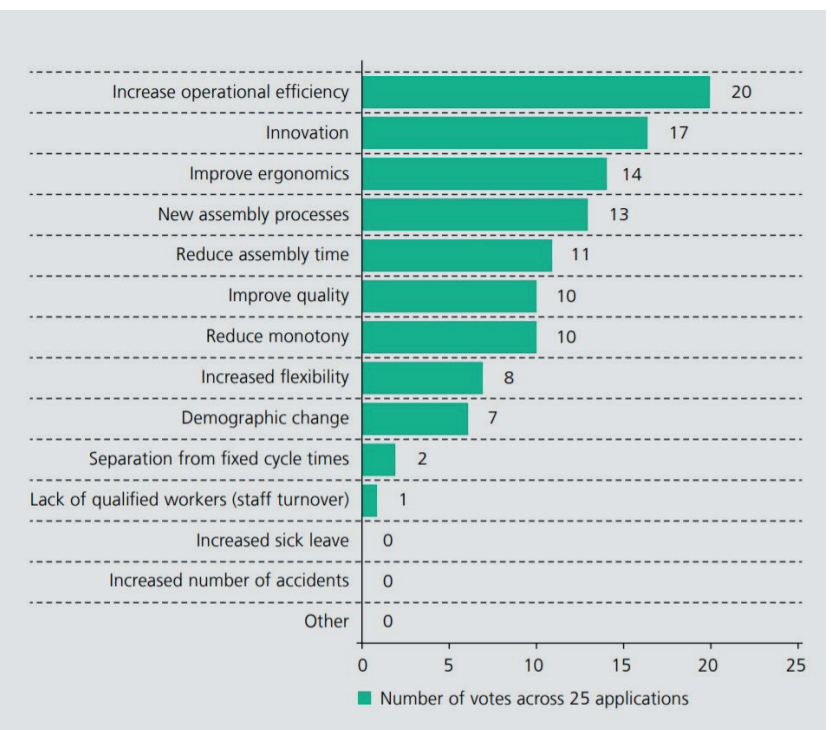

2. ábra: könnyüsúlyú robotok alkalmazásának okai [2]

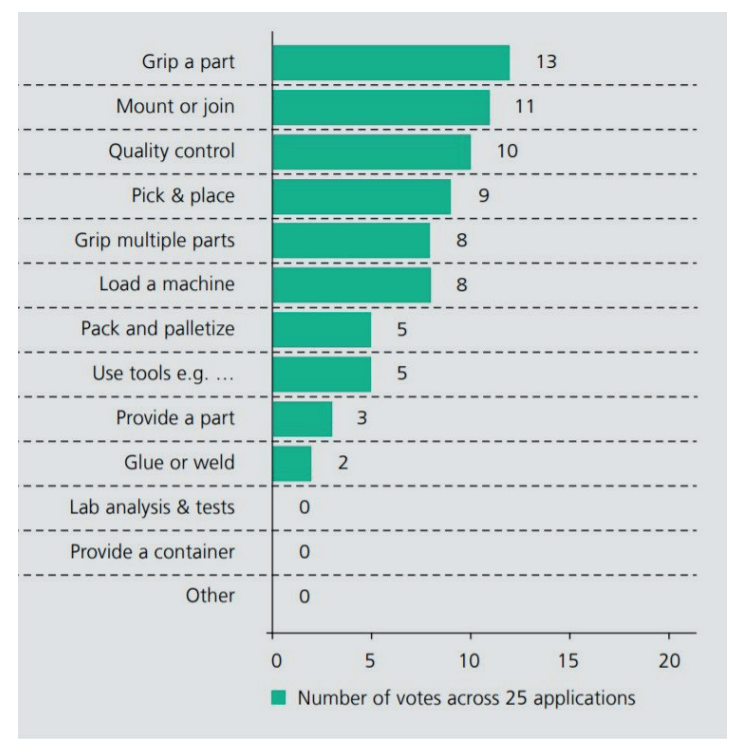

3. ábra: felmérésben szereplő robotok alkalmazásának típusai [2]

A felmérésböl látszik, hogy a robotok nagy százalékban valamilyen megfogó segítségével alkatrész manipulációt végeznek. Ehhez általában vákuumos megfogót, vagy kétujjas megfogót alkalmaznak.

\section{Kobotos szerelésben alkalmazott kétujjas megfogók és korlátaik}

Az iparban használatos kétujjas megfogóknak a költsége sok esetben egy nagyságrendbe eshet a robot költségével, továbbá ahhoz, hogy a megfogó egy adott termék megfogására alkalmas legyen megfogópofa tervezése és gyártása is szükséges, amely sok esetben nem egyszerü, gyakran költséges feladat és a termék esetleges változása, vagy egy másik termékre való átállás másik megfogópofa alkalmazását igényli. Ennek ára bizonyos esetekben minimálisra csökkenthetö, amennyiben a megfogópofa 3D nyomtatás segítségével elöállitható. Előfordulhat, hogy egyes alkalmazásoknál komplexebb megfogást kell alkalmazni, ami már a két ujjas megfogóval nem kivitelezhető. Ezekben az esetekben jöhetnek szóba a háromujjas megfogók.

\section{Háromujjas megfogó alkalmazási módjai és vezérlésének továbbfejlesztése}

A 4. ábra bal oldalán a "pinch" módban a megfogó 2 ujjasként müködik, mivel az egyező oldalon levő "B" és "C" ujja összezárva együtt mozog. A következő mód az "scissor", amikor pont ezt az összezáró-szétnyiló képességet használjuk egy tárgy felcsippentésére. A harmadik "wide" módban a "B" és "C" ujjak legyezőszerüen szétnyilva széles megfogást biztositanak hosszabb tárgyak biztos megfogására. A bal szélső "normal" megfogás esetén a három ujj az összezáródás síkjában párhuzamosan mozog és a tárgy relatív helyzetétöl függően rá is fordulnak az ujjpercek a tárgyra. 

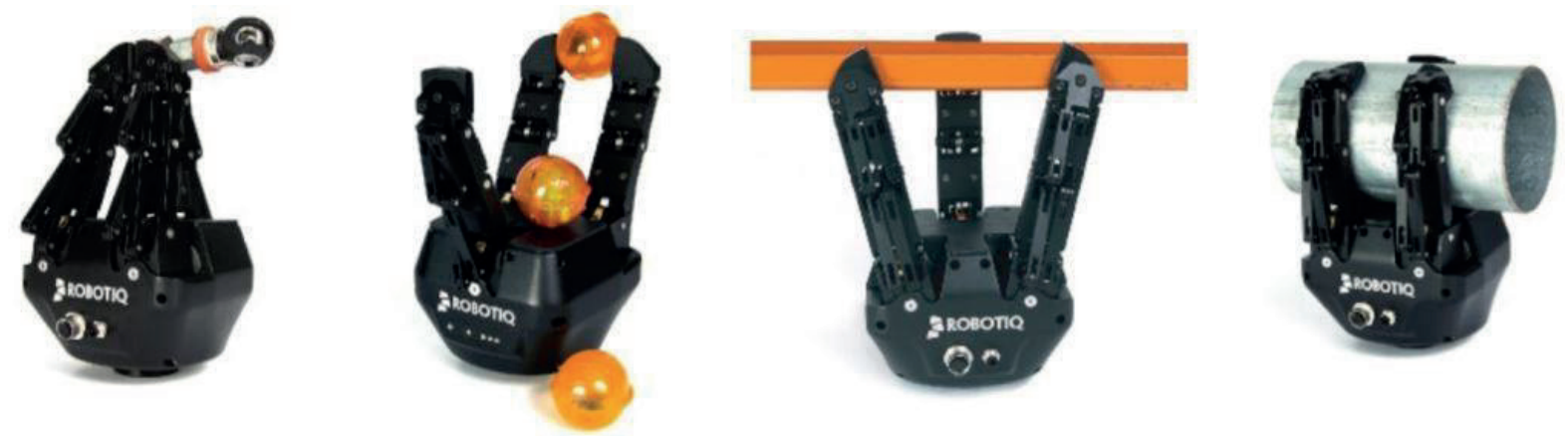

4. ábra: A Robotiq háromujjas megfogójának fogástípusai

Ilyen típusú megfogót alkalmazott négy csapat (köztük a gyöztes is) a DARPA 2013as robotikai versenyén [3].

A LinkageDesigner [4] a Wolfram Mathematica egy add-in csomagja, amely mechanizmusok tervezésre, modellezésre, valamint szimulációra alkalmazható. 2006-óta a Wolfram Research terméklistáján is szerepel. Ennek a programcsomagnak a használatával képesek vagyunk egész ipari cellák modelljeinek előállítására, segítségével létrehozhatjuk a cella digitális ikerpárját. Ahhoz, hogy el tudjuk készíteni a megfogó „Linkage" modelljét, pontos geometriai modellre volt szükség. Mivel a gyártó csak befoglaló geometriát ad közre, így "Reverse engineering" módszerrel elkészitettük a megfogó pontos geometriai modelljét (5. ábra), igy a Linkage skeleton modellje már pontos geometriai paraméterekkel is feltölthettük.

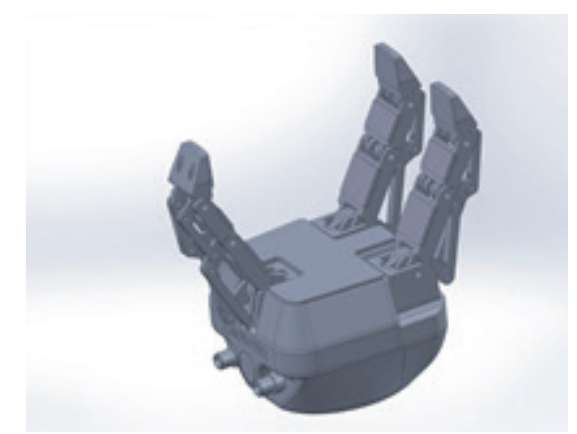

5. ábra: A háromujjas megfogó 3D modellje

Az így kapott megfogó modell integrálható egy robotos cella modelljébe, mely mint digitális ikerként pl. az ApertusVR segitségével megjelenithető.

Az ApertusVR [5] egy MIT licenszü, nyiltt forráskódú, platformfüggetlen programozói könyvtár, amit az SZTAKI megosztott virtuális valóság csoportja fejleszt, többek között azzal a céllal, hogy az iparban alkalmazott merev, vizualizációs célokra használt szoftvereket kiváltsa. Külső szenzorok jeleinek beágyazása és megjelenitése sokkal egyszerübb ezzel a rendszerrel, mint a hagyományos, többnyire 3D-játékok fejlesztésére használt programokkal. Virtuális, kiterjesztett és kevert valóság integrálására egyaránt használható, így a robotos környezetünkben is kiválóan tudjuk alkalmazni a mélységi kamerából nyert adatok és a 3D modell "összefésülésénél". Skálázhatósága és elosztottsága révén könnyen illeszthető már 
meglévő alkalmazásokhoz (mint például az IBM Node-RED [6] nevü programjához), egy új alapvetően vizuális absztrakciós réteget képezve a hardverek és a szoftverek között.

Az elöbb emlitett Node-RED-et kifejezetten loT alkalmazások gyors prototipusfejlesztéséhez találták ki, ahol különböző típusú rendszereket kell összekapcsolni.

Mi az ApertusVR könyvtárat kapcsoltuk össze a magas szintü robotvezérlésünkkel (az URSZTAKI-val), amiben a 3 ujjas megfogó is helyet kapott. Az URSZTAKI keretrendszer létrehozásának több célja is volt.

Egyrészt egy olyan felület létrehozása, ami lehetővé teszi a robotok moduláris programozását, hogy a robot-programnyelv-függetlenités mellett a késöbbiekben magasabb szintü vezérlöhöz (pl. MES-hez) lehessen csatlakoztatni a rendszert.

Másrészt olyan keretrendszer kidolgozása, amelyben könnyen lehet létrehozni új alprogramokat (feladatokat) és ezeket egyszerüen el lehet juttatni további robotokra.

Harmadrészt olyan modularitás kidolgozása, amellyel könnyedén kezelhetőek a különböző felszereltségü robotok.

Ezen célok elérése érdekében a program script fájlokra épül, amelyek beágyazódnak a robotprogramba, majd onnan néhány függvény hivásával indulnak. Ezáltal a módosításokhoz csak szöveges fájlokat kell átírni, azok frissitése könnyen automatizálható és verziójuk követhetö. A megvalósitás esetünkben UR robotkarokkal történt.

A Robotiq 3 ujjas megfogója kifejezetten támogatja UR kobotokra való felszerelését, mind hardveresen, mind a kobot script nyelvébe ágyazódó speciális utasitáskészlettel. A részletes dokumentáció azonban megmutatta, hogy az UR script szoftver nem használja ki a megfogó összes képességét (4. ábra), csak egy limitált elemkészlet került implementálásra. Ebböl az okból kifolyólag saját fejlesztéssel a scriptet bővitettük, mely már lehetővé teszi az egyes ujjak független mozgatást mind a négy mozgási irányba ("A", "B" és "C" ujjak valamint a "B" és "C" ujj egymás felé való "S" mozgását). A saját fejlesztésü script mozgásonként megadja a müvelet után a fenti négy pontos pozíciót, valamint azt, hogy egy megfogási müvelet során melyik ujj érte el a programozott értéket, vagy tárgyat érzékelve korábban állt-e meg. Ezzel a bővített scripttel fut az URSZTAKI.

A csukló-koordinátáinak a robotvezérlö egységétöl TCP/IP protokollt és egy belső hálózatot használva jutnak el a 3D-s megjelenitöhöz, ami szinte valós időben tudja követni a robot mozgását, egyfajta digitális ikert, vagy más néven árnyékot képezve (6. ábra). 


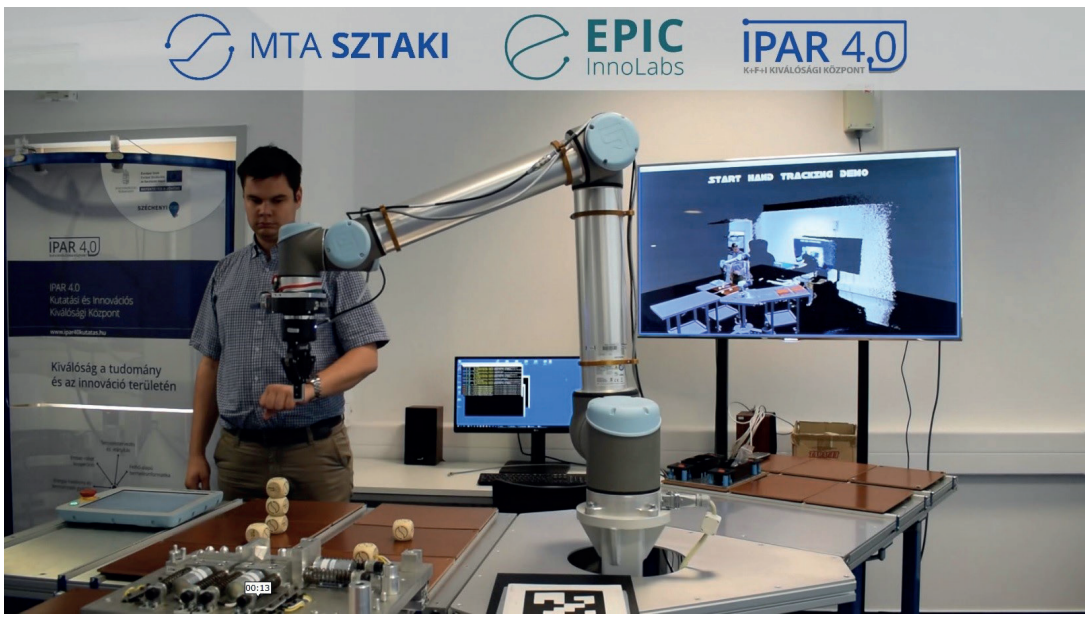

6. ábra: UR10-es kobotos környezet és a digitális iker megjelenitése a háttérben

\section{Példák bemutatása}

Ebben a részben három példán keresztül szeretnénk bemutatni az eddigi fejlesztéseinket.

\section{1. példa: 3D szkennelés robottal - 7. ábra}

A kollaboratív munkakörnyezethez véleményünk szerint hozzátartozik, hogy az emberekés a kobotok osztozzanak a munkaeszközökön is. Ez csakakkor lehetséges, ha mindkét fél meg tudja fogni a tárgyalt eszközt. Az embereknek szánt termékek esetében az ergonómia már alap terméktervezési követelmény, de amennyiben azt szeretnénk, hogy a kobot is meg tudja fogni ugyan azt az eszközt, akkor gyártásnál erre is figyelni kell, vagy ki kell egészitenünk egy adapterrel a terméket, aminek a csatlakozását biztositani kell. Esetünkben az utóbbit választottuk, hogy egy állványra is rögzithető kézi szkennert a kobot mozgatni tudjon. Az optimális szkennelés céljából a TCP (Tool Center Point) értékét (ami a robot „munkapontja”, egy relatív pozíció az utolsó csukló végéhez viszonyitva) a szkennelési távolságnak megfelelően kellett beállítani, amit azáltalunk használt Artec Space Spider technikai specifikációja [7] határozott meg.

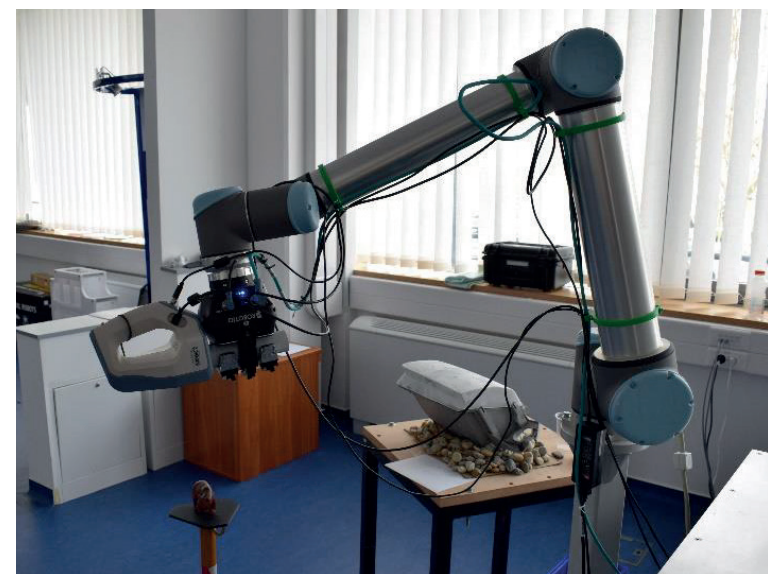

7. ábra: UR10-es kobotos szkennelés

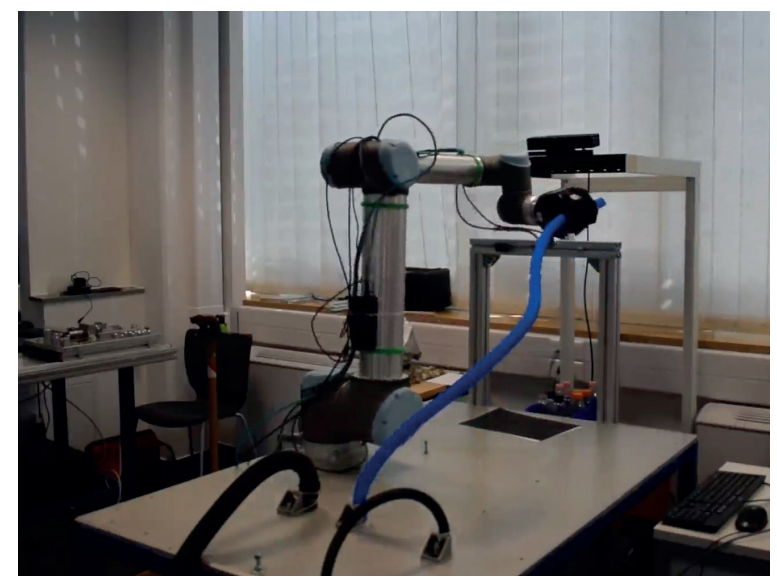

8. ábra: Rugalmas cső manipuláció UR10-es kobottal 
2. példa: Rugalmas csövek csatlakoztatása - 8. ábra

Az iparban egy nem szokványos és kihivásokkal teli feladat a rugalmas csövek manipulációja, ami egy háromujjas megfogóval stabilabb megvalósítást eredményezhet. Esetünkben nem csak a megfogó normál megfogását alkalmaztuk, de a megfogási detektálást is. A robot megfelelő mozgáspályájának programozása történhet kizárólag az egyik rögzitett csövég, a csőhossz és a csatlakozási pozíció ismeretében, vagy a késöbb akár az ArtiMinds RPS [8] és egy erő-nyomatékmérö cella segitségével.

\section{Példa: Müanyag palack felemelése - 9(c) ábra}

Robotos környezetben sok olyan feladat létezik, ahol valamilyen kis mechanikai teherbírással rendelkezö, törékeny vagy könnyen deformálható tárgyat kell manipulálni a robot segítségével. Már tárgyaltuk, hogy milyen sok megfogási módot alkalmazhatunk, azonban egyiknél sem tudunk valós idejü és pontos visszajelzést kapni a megfogott teströl.

Ahhoz, hogy a megfogónkat minél összetettebb és egy egyszerü megfogó képességeit meghaladó feladatok megoldására is képessé tegyük, az ujjak utolsó tagjára (az ún. "Distal Phalanx” részre) egy-egy erőmérő szenzort - 9(a) ábra rögzitettünk 3D nyomtatott adapter - 9(b) ábra - segítségével [9], így pontosan mérhetjük, hogy a megfogási pontokban mekkora eröhatás éri a megfogott tárgyat. A kisérletek várakozásunkkal ellentétben azt mutatták, hogy a pontos erőhatás mérése mellett nem becsülhetö jól a felemelt tárgy tömege, mert az ismétléses mérések nagy szórást mutattak.

Ugyanakkor sikeres volt a feladat abból a szempontból, hogy ezzel a rendszerrel képesek vagyunk felemelni egy üres PET palackot, annak megroppantása nélkül, amit abban az esetben is megtart a robot, ha azt emelés közben megtöltjük vízzel.

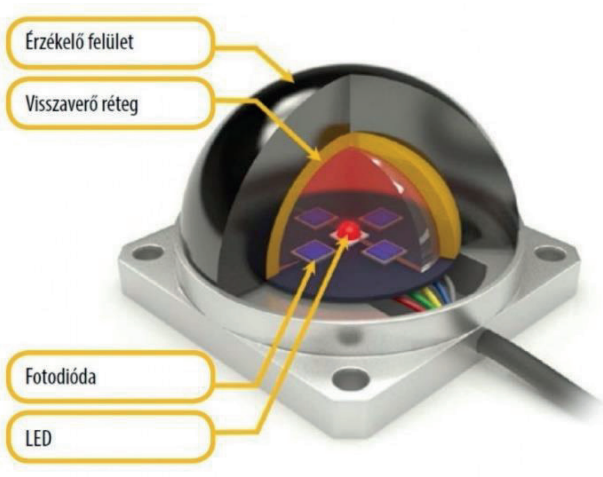

(a) [10]

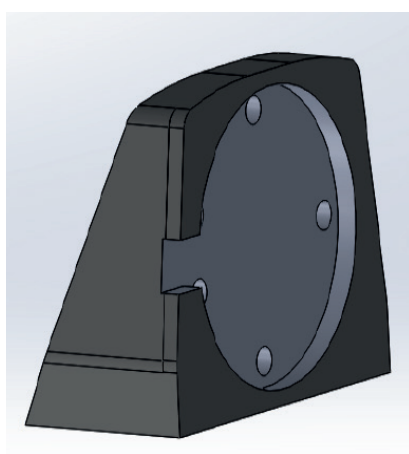

(b)

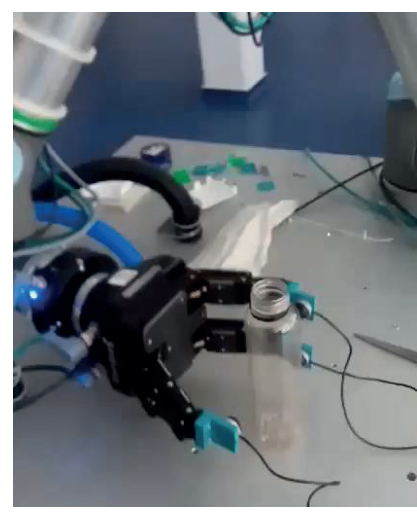

(c)

9. ábra: Erőmérő szenzorokkal kiegészitett megfogó alkalmazása

Hasonló kísérleteket végzett KABOLI kollégáival együtt [11]. 


\section{Összegzés}

Az ismertetett környezet alkalmas arra, hogy gyorsan újabb példaalkalmazásokat fejlesszünk, az Ipar 4.0 elveinek megfelelően az alkalmazások digitális ikerpárját is létrehozva, valamint egyedi feladatokra is egységesitett környezetben dolgozhassunk.A három példa mutatjaa 3ujjas megfogósokrétükihasználhatóságát. Ugyanakkor a tapasztalatunk azt mutatja, hogy a megfogó sokféle üzemmódjának elönyeit jelentősen korlátozza a megfogó relativ nagysága a robotkarhoz viszonyitva. Sok alkalmazás, amely felmerült, a megfogó mérete és kábeligénye miatt (3 csatlakozása van) nem valósitható meg. Az ujjakra szerelt erőszenzorok helyett a közeljövöben a kar és a megfogó közé illesztett hagyományos 6 tengelyes eröszenzorral kivánjuk a kisérleteket folytatni.

\section{Köszönetnyilvánitás}

A bemutatott kutatást a „Felsőoktatási Intézményi Kiválósági Program - Digitális ipari technológiák kutatása a Széchenyi István Egyetemen" projekt (20523-3/2018/ FEKUTSTRAT) támogatta. A kutatáshoz szükséges infrastruktúra pedig az „Ipar 4.0 kutatási és innovációs kiválósági központ" projekt (GINOP-2.3.2-15-2016-00002) keretében valósult meg.

\section{Irodalomjegyzék}

[1] Monostori, L., Kádár, B., Bauernhansl, T., Kondoh, S., Kumara, S., Reinhart, G., Sauer, O., Schuh, G., Sihn, W. and Ueda, K., 2016. Cyber-physical systems in manufacturing. Cirp Annals, 65(2), pp.621-641.

[2] Bauer, W., Bender, M., Braun, M., Rally, P. and Scholtz, O., 2016. Lightweight robots in manual assembly - best to start simply. Frauenhofer-Institut für Arbeitswirtschaft und Organisation IAO, Stuttgart.

https://www.produktionsmanagement.iao.fraunhofer.de/content/dam/ produktionsmanagement/de/documents/LBR/Studie-LeichtbauroboterFraunhofer-IAO-2016-EN.pdf, utolsó letöltés: 2019.10.16.

[3] https://blog.robotiq.com/bid/69213/DARPA-Robotic-Challenge-2013-WonUsing-Robotiq-Adaptive-Grippers, utolsó letöltés: 2019.10.16.

[4] www.linkagedesigner.com/, utolsó letöltés: 2019.10.16.

[5] http://apertusvr.org/, utolsó letöltés: 2019.10.16.

[6] https://nodered.org/, utolsó letöltés: 2019.10.16.

[7] https://www.artec3d.com/portable-3d-scanners/artec-spider\#specifications, utolsó letöltés: 2019.10.16.

[8] https://www.artiminds.com/, utolsó letöltés: 2019.10.16.

[9] Bencze Kristóf: Eröszenzor alkalmazása robotos környezetben, Diplomaterv, BME GTT, 2018

[10] http://www.techmonitor.hu/piacmonitor/elemezes-velemeny/az-ero-legyenveled-20161001, utolsó letöltés: 2019.10.16.

[11] Kaboli, M., Yao, K. and Cheng, G., 2016, November. Tactile-based manipulation of deformable objects with dynamic center of mass. In 2016 IEEE-RAS 16th International Conference on Humanoid Robots (Humanoids), IEEE, pp. 752-757. 
Tartalomszolgáltatások: könyvtárak, levéltárak, múzeumok 


\title{
GDPR és a köznevelési intézmények - a GDPR bevezetésének 13+1 lépése a köznevelési intézményekben
}

\author{
Albert Ágota \\ adatvédelmi tisztviselö \\ dralbertagota @gdprszakszeruen.hu
}

\section{GDPR in the institutions of public education}

The topic of this presentation is the steps of the formation of an adequate data protection of the GDPR instructions in the institutions of public education and the discussion of the most important problems, which are particularly related to these institutions: how can we start becoming GDPR-compatible? What are the greatest obstacles (besides the issue of how to take pictures) and "how we can put out the fire"? How does an institution of public education differ from a "simple" member of any market?

Since the 25th of May, 2018, these institutions - independent from their maintainer - are being regulated by the GDPR, which means a great challange to them. Apart from the vast amount of data that has to be processed daily, they face situations like

- the processing of data is regulated by a number of sector laws (law on educational register, law on public education, Public Servants' Act, Labour Code, law on taxes, etc.)

- the special composition of the data subjects (children, parents, employees, other data subjects)

- as data controllers they have complex social network (maintainer, local authority, community of parents, student organizations, churches, supervising organs, different authorities, business partners, foreign partner intitutions etc.), through which significant transfers of personal data happen

- they can process data not only as data controllers but also as data processors, (e.g.: secondary school entrance exams, organizing high level „érettségi" etc.) and

- the supervision of employees and students requires a different approach from schools than from a traditional member of the market (using the followings (e.g.): register of working hours, video monitoring system, smart devices and internet in the possession of institutions).

Keywords: GDPR, public education, data protection

Hogyan válhat egy intézmény GDPR-kompatibilissé?

\section{1. lépés}

Tudatositsuk, a GDPR igen is vonatkozik az intézményünkre. Ha homokba dugjuk a fejünket és azt mondjuk hogy nem, attól még igen. Söt, mindenért az adatkezelö, azaz az intézményvezető a felelős egyszemélyben. Azonban nem elég, ha csak az igazgató érzi úgy, a nyakába szakadt még egy teljesitendő feladat, hanem az 
iskola minden alkalmazottjának tudnia kell, ha adatot kezel, azt a GDPR elöírásainak megfelelően kell tennie. Vonatkozik ez az osztályfönökökre, a rendszergazdára, az iskolapszichológusra és a portásra is, mindenkire, aki valamilyen módon személyes adattal kapcsolatba kerül. Természetesen más adatokhoz fér hozzá egy gazdaságis és másokhoz a könyvtáros, éppen ezért fontos, hogy mindenki tisztában legyen a jogosultságával és felelősségi körével.

\section{2. lépés}

Vegyünk igénybe szakembert. A rendelet alkotói úgy gondolták, az iskolák mint közérdek alapján közfeladatot végrehajtó intézmények az adatvédelem szempontjából „veszélyes üzemek”, ezért kötelező adatvédelmi tisztviselőt (a szakzsargonban DPO-t) kinevezniük. Ez a fenntartó kötelessége, a kinevezés elmaradása GDPR-ellenes. Az adatvédelem speciális ismereteket követel, amelyek nem lesznek meg attól, hogy például egy pedagógusra rátestáljuk ezt a feladatot. Söt, elötanulmányok nélkül egy-két napos intenziv GDPR kurzus is maximum annyira elég, hogy az áldozatban tudatosuljon, mennyi mindent nem tud. Olyan személy sem lehet DPO, aki munkaköréböl adódóan felelös az adatvédelmi szabályozás betartásáért (pl. az intézmény vezetője).

Az adatvédelmi tisztviselő csak tanácsokat adhat, a döntés az adatkezelőé, ahogy a felelösség is.

\section{3. lépés}

Térképezzük fel, milyen személyes adatokat kezel az iskolánk. Ahogy az egészségügy, úgy a köznevelés is elképzelhetetlen adathegyek nélkül.

Az adatok feltérképezéséhez elkerülhetetlen az olyan alapfogalmak megismerése, pl. mi a személyes adat és mit jelentenek a személyes adat különleges kategóriái, hiszen ezek pontos behatárolása nélkül elsikkadhatnak igen fontos adatkezelések. Személyes adat egy osztályzat? Igen. És különleges személyes adat az, hogy Bence vagy Hanna mogyoróallergiás? Igen. És az személyes adat, hogy az ötödikesek közül a magas vörös kölyök intőt kapott? Igen, amennyiben az ötödikesek között annyi magas vörös kölyök van, hogy már ennyi információval is beazonositható az adott diák.

A harmadik lépés tehát fellelniaz intézménybena személyes adatokat, beazonositani az adatkezeléseket és olyan adattérképeket gyártani, amelyek alapján tisztázható egy-egy adat életútja, azaz

- melyik adat honnan és hogyan érkezett be (szülőtől, tanulótól, fenntartótól stb.),

- ki kezeli azt házon belül (titkárság, osztályfönök, gazdaságis kolléga stb.),

- hol és hogyan tároljuk (papíron, elektronikusan vagy mindkettőn),

- hogyan, hova és mi alapján továbbítjuk (lásd a köznevelési törvény felsorolását) és

- mikor kell leselejtezni (megsemmisiteni) azt. 


\section{4. lépés}

Tisztítsuk meg az adatvagyont. A felesleges munka elkerülése érdekében el kell döntenünk, hogy mely adatot kezelhetjük tovább és melyet nem. Föbb szempontok:

- azadott adat kezelése megfelelazalapelveknek? Jogszerüen, tisztességesen és átláthatóan kezeljük?

- van jogalapunk az adott személyes adat kezelésére? Ha nincs, akkor vagy teljesiteni kell a hivatkozott jogalaphoz szükséges feltételt (pl. be kell szerezni a hozzájárulást), vagy kiméletlenül ki kell selejtezni (meg kell semmisiteni) azt. A "mindig így szoktuk” jogalapot a GDPR nem ismeri, a hozzájárulás pedig - a közhiedelemmelellentétben - nem univerzálisan használhatójogalap, mivelaz bármikor visszavonható, illetve egyes helyzetekben (pl. alá- és fölérendeltségi viszonyban, megkérdőjelezhetö önkéntesség esetén) nem alkalmazható.

- idöben szavatos még az adott adat? A vonatkozó jogszabályok (pl. 20/2012. (VIII. 31.) EMMI rendelet 1. sz. melléklete), illetve az intézményünk irattári terve tájékoztatást nyújt, hogy melyik adat meddig örizhetö. Ha lejárt a megörzési idö, a kezelés nem jogszerü.

- szükség van az adott adatkezelésre? Van konkrét cél vagy csak raktározzuk az adatot, majd csak jó lesz valamire? Ha nincs cél, az adat kezelése nem jogszerü.

- az adatkezelés céljának eléréséhez feltétlen szükség van az adott adatra? A GDPR elkötelezett hive az adattakarékosságnak, azaz nem támogatja olyan adat kezelését, amely nem szükséges az adott cél eléréséhez. A felesleges adatoktól szintén meg kell szabadulnunk.

- helyes, pontos az adat? Ha nem az, akkor kijavitható, helyesbithetö? Ha nem, döntenünk kell a sorsáról. A pontatlan, hibás személyes adat is személyes adat.

- megfelelő biztonságot biztosítunk az adatnak?

Minél nagyobb és minél régebbi az intézményünk, annál nagyobb a feltérképezés és kiválogatás munkaigénye, ráadásul nem ez az a feladat, amit gyakornokokra felelösen rá lehetne bízni.

Ha lekarcsúsitottuk az adatvagyonunkat, jöhet az adattérképek újrarajzolása. Ezek már alkalmas kiinduló pontjai az iskola adatkezelési nyilvántartásának, amely a GDPR alapján kötelező, és amelyet egy adatvédelmi hatósági ellenőrzés során az elszámoltathatóság elvének megfelelően - be kell tudni mutatnunk. Ahogy az iskola leltározza a számítógépeit, labdáit meg csontvázait, úgy az adatkezeléseit is leltároznia kell.

\section{5. lépés}

Határozzuk meg az egyes adatkezelések követelményeit. Az adatkezelések döntő többségében jogszabályok határozzák meg, hogy milyen adatot kezelhet, hova továbbithat az iskola. Az iskolák közérdekü feladataik végrehajtásához szükséges adatkezeléseknél a jogalap a GDPR 6. cikk (1) bekezdés e) pontjában meghatározott közérdek lesz és ez a jogalap - a felügyeleti hatóság álláspontja szerint - elnyeli a 
további adatkezelési jogalapokat, valamint be kell tartani a GDPR alapelveit is.

Vannak olyan adatkezelések, amelyek bonyolultabbak, mint egy átlag munkáltató adatkezelései. Egy iskolában pl. sokkal nehezebb a munkahelyiés magánhasználatot elkülöníteni - decemberben a pedagógus használatában lévő számítógépröl keresettbeigli receptakarácsonyivacsoráhozkellvagyahagyományokkalfoglalkozó osztályfönöki órára? A cicalány007@ e-mail cím a titkos barátnő címe vagy egy diák anyukájáé, netalán magáé a diáké? Talán nincs még egy olyan munkáltató, ahol a magánszférát olyan nehéz elválasztani a munkahelyi kötelezettségek teljesítésétől, mint egy átlagos iskola.

Lehet még „problémás” adatkezeléseket sorolni, pl. a "normál” körülmények között általában jogos érdekre hivatkozó adatkezelésekhez milyen jogalap használható az iskolákban? Például:

- az intézményben felszerelt kamerák felvételeivel,

- a diákok internethasználatának ellenörzésével,

- az iskolai rendezvényen készült tömegfelvételekkel kapcsolatos adatkezelés, amelyeken nemcsak a ballagó diák van, hanem közeli és távoli rokonsága nullától száz éves korig, és amely képek a modern technikának köszönhetően bármikor portréfotó minőségre nagyithatók.

Az adattovábbitások vizsgálata is szükséges, hiszen az iskola nemcsak jogszabály alapján továbbit adatokat harmadik személyeknek, hanem pl. testvériskolai kapcsolattartás vagy versenyekre jelentkezés keretében is. Söt, iskolai kórustalálkozót szervezhetnek pl. Kinában, amely harmadik országnak számít, szállást pedig oda is foglalni kell sok-sok személyes adat megadásával. Ráadásul az adattovábbítást nyilván kell tartanunk, különben hogyan fogjuk tudni megmondani az érintettnek, hogy mikor, hova, kinek, mi alapján és milyen garanciákkal továbbitottuk a személyes adatait?

Kétségeink eldöntésében segitséget nyújthatnak a NAlH anyagai. ${ }^{1}$

\section{6. lépés}

Igazítsuk a belső szabályzatainkat és utasításainkat a GDPR elöírásaihoz. Az iskoláknak kötelező adatvédelmi szabályzatot késziteniük, a GDPR azonban a konkrét tartalmat az adatkezelöre bízza.

Mi legyen benne? Amit fontosnak tartunk, pl::

- adatkezelések részletes leírása, különösen a speciális eseteké (pl. tanulmányi és tantestületi kirándulással, iskolaújsággal, intézményi honlappal kapcsolatos adatkezelések, dokumentum másolatok kezelése stb.)

- adatfeldolgozókkal kapcsolatos rendelkezések, illetve az olyan adatkezelések leírása, amelyek esetében az iskolánk adatfeldolgozó (pl. központi felmérések, tanulmányi versenyek stb.) 
- érintetti jogok leirása és a jogok érvényesitésének módja (az érintetti tájékoztatás formái és kötelező tartalma, érintetti kérelmekre válaszadásnak, a hozzájárulás visszavonásának, az adatkezelés ellen tiltakozásnak, törlési kérelemnek adminisztrációja stb.)

- kötelező, illetve elszámoltathatósági szempontból fontos nyilvántartások tartalma (pl. az adatkezelések, adattovábbitások és adatvédelmi incidensek nyilvántartása stb.)

- adatvédelmi incidens esetén követendő protokoll elöre elkészített nyomtatványokkal, nehogy a nagy kapkodásban kimaradjon valami,

- olyan speciális adatkezelések, mint osztálycsoport létrehozása közösségi oldalon, oktatással kapcsolatos appok használata (pl. Kahoot!), tanárok-diákok saját loT-eszközeinek használata stb.

- beépitett adatvédelem érvényesitéséhez szükséges eljárások (pl. adatok biztonságos tárolásának, továbbitásának módja, jogosultságok kiosztásának elvei stb.)

- az adatvédelmi tisztviselö feladatai és hatásköre.

- Az adatvédelmi és adatbiztonsági szabályzaton kivül szükségünk van még egyéb dokumentumokra is, $\mathrm{pl}$.

- speciális szabályzatok megalkotása (kameramüködtetési, beléptetési, informatikai, információ biztonsági, image policy stb.)

- érdekmérlegelési tesztek végzésének eljárásrendje, kockázatfelmérés és kezelés módszerei stb.

\section{7. lépés}

Készitsük el az adatkezelési tájékoztatókat. A GDPR sarkalatos pontja az érintettek tájékoztatása, ennek elmaradása komoly szankciókat vonhat maga után annyi kedvezménnyel, hogy költségvetési intézmény esetén a maximális közigazgatási bírság 20 millió forint.

Milyen tájékoztatókra van szükség? Célszerü minimum három adatkezelési tájékoztatót késziteni, egyet a diákoknak, egyet a szülöknek, egyet pedig az alkalmazottaknak. A fenntartónak gondolnia kell még olyan egyéb érintettekre is, mint pl. a szerződéses partnerek, nekik is kell késziteni tájékoztatót.

Az általános adatkezelési tájékoztató általában az iskola honlapján kap helyet, de mindenképpen kell nyomtatott verzió is, amely az intézmény titkárságán bármikor elérhető. A speciális, egy-egy adatkezelésre vonatkozó tájékoztatók helyet kaphatnak pl. a beiratkozási és hozzájárulást kérő nyomtatványokon is, így késöbb nincs vita a tekintetben, hogy megtörtént-e az érintettek szükséges tájékoztatása.

\section{8. lépés}

Ültessük át a gyakorlatba a gyerekekkel kapcsolatos eltéréseket. Pl. mi legyen a 14-18 év közötti gyerekkel illetve akkor, ha nagykorú lesz a diák? Ki férhet hozzá a tanuló adataihoz, ki gyakorolja a szülöi felügyeleti jogot? A szülőnek mindenröl joga van tudni, vagy adott esetben a szülövel szemben is védeni kell a gyermek jogait? Elmondhatja-e az iskola, hogy informatika órán milyen témákra keresett 
rá a tinédzser a neten, vagy jobb ezekröl hallgatni? Milyen plusz garanciákat kell beépíteni az adatkezelésekbe akkor, ha az érintett 18 éven aluli?

A GDPR alapján a diákoknak szóló adatkezelési tájékoztatót úgy kell megfogalmazni, hogy korosztályuknak megfelelő mértékben ők is megérthessék az abban foglaltakat és legyenek tisztában pl. azzal, hogy nem kell nekik olyan fotót eltürniük az iskola honlapján, amelyen nagyon nem tetszenek maguknak. A tájékoztató készülhet sok oldalas írásos verzióban, de érdemes megfontolni a videofilm vagy képregény formátumot is.

\section{9. lépés}

Tegyünk azért, hogy az érintettek gyakorolhassák jogaikat, betartva a jogszabályban foglalt határidőt. Nem szabad elfelejtenünk, hogy a szülök speciális érintettek egyrészt saját jogon, másrészt gyermekeik miatt, frusztrációjuk pedig az egeket verheti pl. azért, mert a fiuk vagy lányuk egyfolytában a fülüket rágja, milyen elönytelen kép van róluk az iskola honlapján és legyenek szivesek, intézkedjenek a kép eltávolíttatása érdekében. Éppen ezért célszerü az érintetti kérelmek megfelelő rendezése érdekében a belsö adatkezelési szabályzatban részletesen rögzíteni az eljárásrendet és minden esetben bevonni az adatvédelmi tisztviselőt is.

\section{0. lépés}

Alakitsuk ki az adatvédelmi incidens protokollunkat - és nemcsak a leírása fontos, hanem a begyakorlása is, akár próbaincidens keretében. A 72 órás hatósági bejelentési határidő nagyon rövid és minden egyes bejelentés egyben önfeljelentés is, amely vizsgálatot von maga után. Az incidenskezelés pedig nem annyi, hogy széttárjuk a kezünket, ez most igy sikerült, máskor majd biztos gondosabbak leszünk és kicsit nehezebben lopják majd el a tanáriból a nyitott ablakon keresztül azt a laptopot, amely titkositás nélkül tartalmazott adatot több száz gyerekröl és szüleikröl.

\section{1. lépés}

$\mathrm{Ne}$ felejtkezzünk el a beépített adatvédelemröl. A GDPR összetolja az adatkezelést és az adatvédelmet, az adatkezelőnek pedig mindent meg kell tennie annak érdekében, hogy az érintettek a lehető legnagyobb biztonságban tudják a személyes adataikat. Az adatbiztonság fontos része pl. a számítógépes rendszer védelme, de ide tartoznak olyan triviális dolgok is, mint a jogosultságok kiosztása, a jelszavakkal kapcsolatos elöírások betartatása, a rendszeres biztonsági mentés, a tiszta asztal politika, a szekrények és fiókok zárása, a leselejtezett papírok megsemmisitése stb. Ajánlatos megismerkednünk olyan technikákkal is, mint az álnevesités, az anonimizálás és a titkositás és figyelembe kell venni mindezeket már az adatkezelések megtervezése folyamán is.

\section{2. lépés}

Oktatás és bevezetés. A polcra feltett 500 oldalnyi szabályzat még nem jelenti azt, hogy az iskolánk megfelel a GDPR követelményeinek. Az adatvédelmi kultúrának be kell épülnie a mindennapokba, és nemcsak beépülnie kell, hanem bizonyítanunk 
is tudni kell, hogy a rendeletnek megfelelöen jártunk el. Ehhez szükséges az alkalmazottak képzése, hiszen nem egy személyben az igazgató kezeli az adatokat, hanem minden egyes tanár, pedagógiai asszisztens és még a portás is. Ez nem azt jelenti, hogy mindenkinek tudnia kell mindent, hanem azt, hogy a saját területén mindenki sajátítsa el a szükséges ismereteket, és ne csak bemagolja, hanem alkalmazza is az előírásokat. Az elvileg és általában képzéseknek semmi értelme, csakis annak, ha az alkalmazottak munkaköri szintjükhöz kapcsolódva szereznek értelmezhetö tudást.

\section{3. lépés}

Nemzetközi kapcsolatok. Az iskoláknak szerteágazó nemzetközi kapcsolatai lehetnek, és nemcsak a nemzetiségi iskoláknak, hanem a két tanitási nyelvüeknek, nyelvtagozatosoknak és a "sima" intézményeknek is. A nemzetközi kapcsolatok elengedhetetlen része az adattovábbitás külföldi illetőségü adatkezelő vagy nemzetközi szervezet számára, akár személyes adatok, akár különleges adatok formájában. A GDPR alapján az Európai Gazdasági Térség országai belföldnek számitanak és vannak olyan országok is, amelyek a Bizottság véleménye szerint garantálják az uniós védelemnek megfelelő védelmi szintet, ilyen pl. Svájc, Japán és Uruguay, míg olyan országok, mint az Egyesült Államok, Ukrajna vagy Szerbia harmadik országnak számítanak. Ezekbe az országokba irányuló adattovábbitás esetén speciális feltételeknek kell teljesülnie, amelyek fennállását az iskolának kell bizonyitania akkor is, ha csak Kárpátaljára ruccan ki egy pár napra a 10/a. osztály.

\section{3 + 1. lépés}

Kövessünk nyomon az eseményeket és reagáljunk, ha szükséges. Kétszer ugyanabba a folyóba nem lehet belelépni és ez igaz az adatvédelemre is. Még ha az uniós rendelet maga nem is változik gyakran, a hazai ágazati jogszabályok bármikor módosulhatnak, ahogy várhatóan a jogértelmezés is idővel egyre kifinomultabb lesz. Nemcsak arra van szükség, hogy az iskola ellenörizze a saját adatvédelmi gyakorlatát és folyamatosan az újabb és újabb igényekhez igazitsa azt, hanem arra is, hogy a jogértelmezésnek megfelelö irányvonalat kövesse. Ez az a terület, ahol szintén elengedhetetlenül szükséges az adatvédelmi tisztviselö közremüködése. 


\title{
Kézírásfelismerés Arany János levelein
}

\author{
Bobák Barbara \\ Magyar Tudományos Akadémia Bölcsészettudományi Kutatóközpont \\ Irodalomtudományi Intézet \\ bobak.barbara@btk.mta.hu \\ Gábori Kovács József ${ }^{1}$ \\ Magyar Tudományos Akadémia Bölcsészettudományi Kutatóközpont \\ Irodalomtudományi Intézet \\ kovacs.jozsef@btk.mta.hu
}

Arany János 1865-1869 között titoknoki, majd 1870-1877 között fötitkári minőségben segitette az MTA munkáját. Az író tehát csaknem másfél évtizeden keresztül látott el fontos tudományszervezési feladatokat. ${ }^{2}$ Életművének kutatása ezért elképzelhetetlen hivatali iratainak, levelezésének feltárása és publikálása nélkül. E dokumentumok vizsgálata kiegészitheti olvasmányainak listáját, tisztázhatja, hogy milyen mértékben vett részt az Akadémia kiadványainak elkészitésében, valamint segitséget nyújthat annak felismerésében, hogy a hivatali foglalatosság milyen, eddig nem ismert kapcsolatokat teremthetett az ő költészetével. Továbbá ezek a dokumentumok kulcsszerepet játszhatnak az Akadémia szervezeti rendszerének leirásában, az 1870-es átszervezés okainak, az Akadémia hazai és külföldi intézményes kapcsolatainak feltárásában; reprezentációs szerepének, illetve tudományszervezésben elfoglalt pozíciójának meghatározásában. Az intézmény sokfelé ágazó tudományszervezési feladatait alapvetően meghatározta az a tény, hogy az Akadémia számos tudományterület képviselöit - nyelvés széptudományok, bölcseleti tudományok, törvénytudományok, történeti tudományok, matematikai tudományok és természettudományok - fogta össze a korszakban. E tudományterületek külső - hazai és külföldi - intézményekkel és kutatókkal való kapcsolattartása pedig rendszerint a mindenkori titoknok, illetve az általa vezetett Titoknoki, később Fötitkári Hivatal közvetítésével történt, így Arany János hivatali levelezésének kiadása az emlitett tudományterületek és a hozzájuk a korszakban sorolt tudományágak történetének, fejlödésének, hazai és külhoni intézmény- és kapcsolatrendszerének vizsgálatához is nélkülözhetetlen adatokat nyújthat.

\footnotetext{
1 Gábori Kovács József a tanulmány írásának ideje alatt MTA Prémium Posztdoktori Ösztöndij támogatásban részesült.

2 Gergely Pál. „Bevezetés”. In: Arany János. „Hivatali iratok 2.: Akadémiai évek (1859-77)”. szerk. jegyz. Gergely Pál. Bp. Akadémiai K. (1964) (Arany János összes müvei, 14.): 602-604. ; Arany akadémiai feladatairól lásd még Gergely Pál. „Arany János és az Akadémia." Bp. MTA Irodalomtudományi Intézete - Akadémiai K. (1957). (Irodalomtörténeti füzetek, 11.) ; Keresztury Dezsö. „Csak hangköre más: Arany János 1857-1882." Bp. Szépirodalmi K. (1987): 468-480. Voinovich Géza. „Arany János életrajza 1860-1882.” Bp. Magyar Tudományos Akadémia (1938): 205-214.
} 
Korábban, az Arany János összes müvei címü kritikai kiadás XIV. kötetének összeállítása során Gergely Pál elkészitette Arany akadémiai iratainak jegyzékét. Ö körülbelül 2500 dokumentumot sorolt fel, ám ennek csak kisebb részét - 717 - tette közzé. ${ }^{3}$ Ez a tény és a kötet megjelenése óta eltelt több mint ötven év eredményei szükségessé tették Gergely jegyzékének felülvizsgálatát és kiegészitését. Föként mivel a kötet összeállítása során a szerkesztő szinte csak az Arany által írott hivatali iratok közül válogatott, míg az Akadémia titoknokához írott levelek közül csak a legfontosabbak kerültek a gyüjteménybe. ${ }^{4}$

Mindezeket szem elött tartva vált indokolttá, hogy Arany János hivatali levelezésére essen a választás a gépi kézírásfelismerés és átírás tesztelésére, valamint fejlesztésére. A papíralapú dokumentumok digitalizálásának fontossága kétségbevonhatatlan. A tartós megörzés, az egyszerübb tárolhatóság, a könnyebb és sokrétübb feldolgozhatóság mind indokolja azt. Függetlenül attól, hogy a humán tudományok területén munkálkodó kutatók a mai napig print kiadásokat, továbbá kéziratokat használnak munkájukhoz, egyre több írásos anyag rendelkezik elektronikus verzióval is, az újonnan születő müvek jelentős hányada pedig már eleve digitális formában jön létre. A technika fejlödésével és térhóditásával tehát megváltozott a tudásanyag megszerzésének - és létrehozásának - a módja, megváltoztak az információhoz való hozzáférésre vonatkozó igények, ami szintén a digitalizálás elkerülhetetlensége felé mutat.

Egy szöveges dokumentum digitalizálásának legföbb lépései a szkennelés és a karakterfelismerés, legyen szó akár nyomtatott, akár kézzel irt szövegröl. Nyomtatott szövegek esetén az optikai karakterfelismerés (OCR), írott szövegek esetén pedig a kézirásfelismerés (HTR) technológiáját alkalmazzuk.

\section{Az OCR}

A digitalizálási folyamat első lépése a szkennelés, amikor a papíralapú dokumentumokról jó minőségü, magas pontsürüségü (min. 600 dpi5) szkennelt képek készülnek. Ezt követöen a képeken valamilyen OCR program kerül futtatásra, amellyel további információt tudunk kinyerni a szkennelt anyagból. Az optikai karakterfelismerés (Optical Character Recognition - OCR) olyan technológia, amely felismerhetővétesziegyképenvagyszkenneltdokumentumonszereplökaraktereket, számokat és központozási jeleket. A folyamatban nehézséget jelentenek azok a zajnak nevezett elemek, amelyek egy nyomtatott dokumentumban elöfordulhatnak, például egy folt vagy gyürődés a papíron, homályos háttér, tintafoltok stb. A karakterfelismerö teljesitményét tanulással lehet fejleszteni, így idővel képessé válik olyan karakterek és minták azonositására is, amelyekkel korábban nem találkozott. ${ }^{6}$

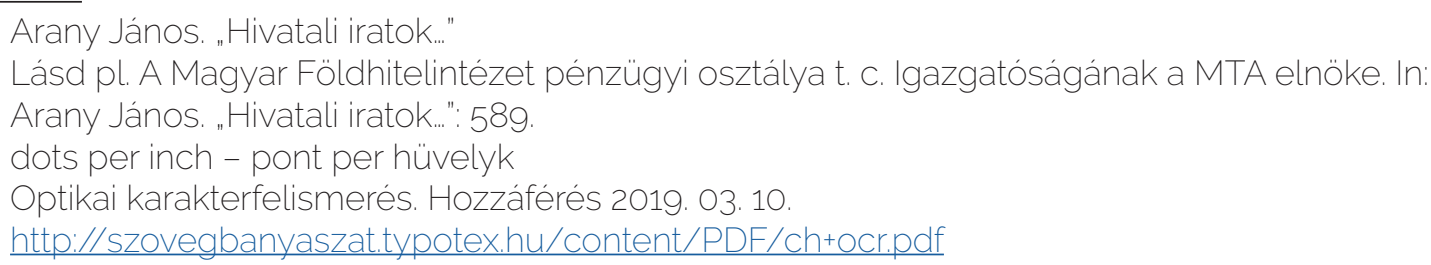




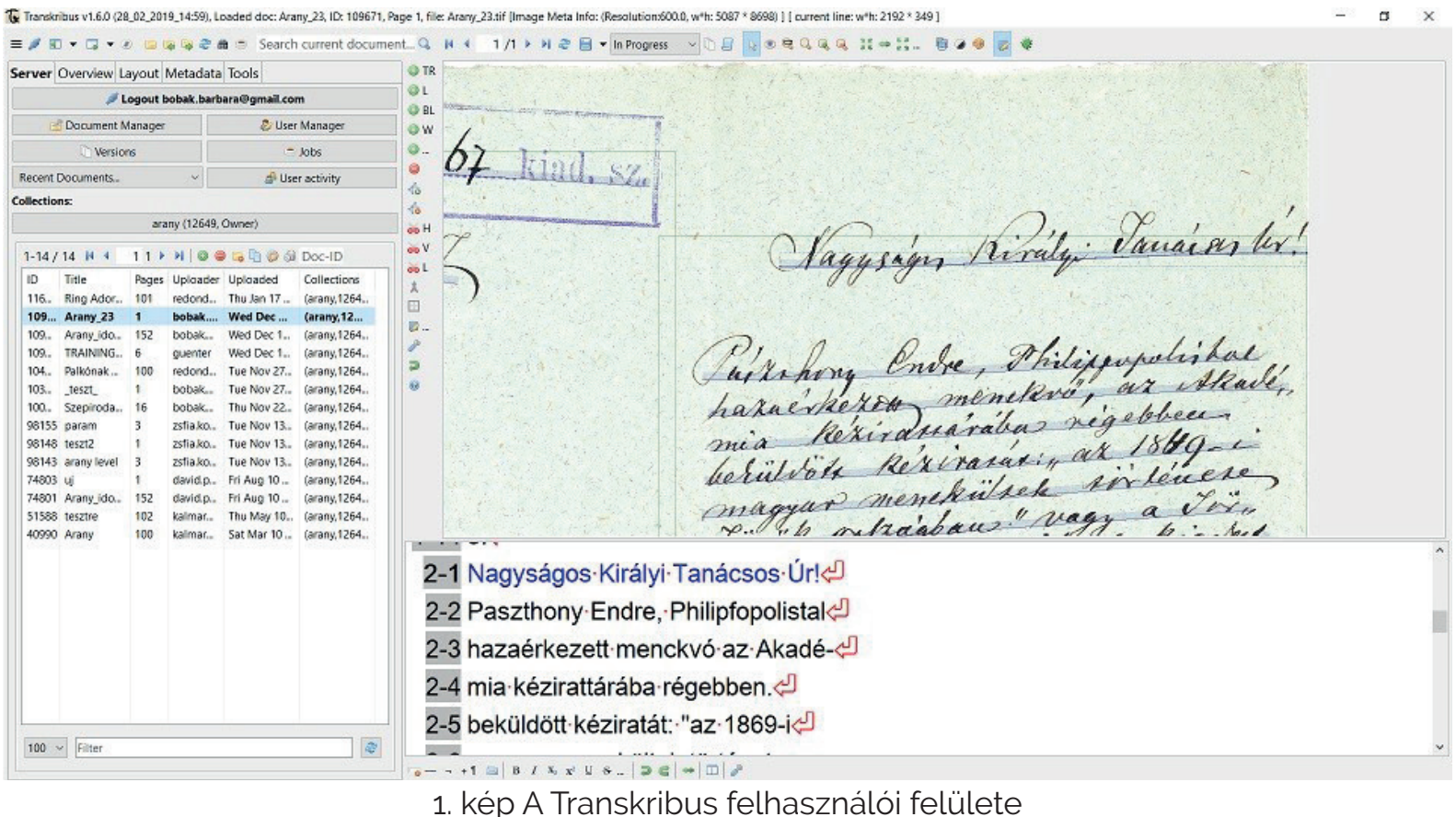

Az OCR alkalmazása által tehát a képekböl szövegfájl formátumok jönnek létre, amelyek szerkeszthetők és kereshetők, vagyis alkalmasak a feldolgozásra.

\section{A HTR}

Ha a digitalizálni kivánt dokumentum nem nyomtatott, hanem kézírásos, abban az esetben kézírásfelismerő (Handwritten Text Recognition - HTR) programra van szükség. A cél ugyanaz, mint a nyomtatott szövegek esetében, azaz a kéziratról készült szkennelt képfájlból feldolgozásra alkalmas szövegfájl formátum létrehozása. A folyamatot itt is nehezitik mindazok a zajelemek, amik a nyomtatott dokumentumokban is elöfordulhatnak, kézirásnál azonban a személyiségjegyekkel is számolni kell, hiszen ahány ember, annyiféle kézírás létezik. Az OCR technológiájához hasonlóan a HTR is tanulási fázison megy keresztül, ami alkalmassá teszi a szöveget alkotó karakterek felismerésére, később pedig új minták azonosítására is.

Az OCR és a HTR térhóditásával olyan számítógépes alkalmazások és online szolgáltatások is megjelentek, amelyek képesek mindkét technológiát alkalmazni a feltöltött dokumentumokon.

\section{Transkribus $^{7}$}

A Transkribus online szolgáltatás, amellyel nyomtatott szövegek és kéziratok felismertetését és átírását végezhetjük, jelentős mennyiségü munkaórát megspórolva. 2016-ban az Innsbruck Egyetem Digitalizálás és Digitális Archiválás 
kutatócsoportja $(D E A)^{8}$ hozta létre a READ ${ }^{9}$ projekt részeként, és azóta is folyamatosan fejlesztés alatt áll. A szolgáltatás, melynek jelentős része nyilt forráskódú, mindenki számára ingyenesen elérhető. A Transkribus, a szolgáltatás honlapjáról egy regisztrációt követően letölthetö és telepithető, használatához azonban internetelérés szükséges.

Az alkalmazás felülete rendkivül felhasználóbarát, logikusan felépitett és tagolt, az egyes funkciók könnyen elérhetök. A kialakításnál láthatóan fontos szempont volt, hogy azok is könnyen boldogulhassanak vele, akik a technológiára kevésbé fogékonyak. A könnyen kezelhetőség célkitüzését az is bizonyitja, hogya szolgáltatás wiki oldalán számos, részletesen leírt és képekkel illusztrált .pdf, valamint videó formátumú használati útmutató tölthető le angol és német nyelven. ${ }^{10}$

\begin{tabular}{|c|c|}
\hline Első modell & Második modell \\
\hline $\begin{array}{l}\text { fo .lf-én - } \\
\text { re. oldy F. } \\
\text { ezennele } \\
\text { Tidlobb } \\
\text { zklá sz. } \\
\text { zoalaááédáéb } \\
\text { eMI. } \\
\text { MM865... } \\
186186 \mathrm{j} \text { é aa } \\
\text { zos. m á a a } \\
\text { s } \\
\text { Nagysags Krályi Taneilcr } \\
\text { aszthoy Endre, Phdifyopolisbol } \\
\text { hazaészezett. menckvö, az Akadé- } \\
\text { mia kezrdttárába régebben. } \\
\text { beküldött keziratati, ,az } 1869-i \\
\text { magyar menekültet törtenéte } \\
\text { Török országban vagy a For- } \\
\text { ténelmi Bizottsag últal kiadat- } \\
\text { m vagy, högy ő maga kiadhasa } \\
\text { mg } \\
\text { s ez autal sányorú helyzeten } \\
\text { valamit könyéthessem, el nmn- } \\
\text { fogadás esetere visszakerven. } \\
\text { a folyó hó 9-én tartott } \\
\text { ostályúles határozatából } \\
\text { szerencsém van. e dolyozatot } \\
\text { aztenni a mondott Bizott } \\
\text { sághozs véleményada } \\
\text { vegon .A menmngrvea jedig elö } \\
\text { re lavható volaa, hogy e kez }\end{array}$ & $\begin{array}{l}5 . \\
7301867 \text { kiad. sz. } \\
720 \text { Toldy J. } \\
\text { ezennel } \\
\text { millobb } \\
\text { iejellilölböz } \\
\text { t i ibi. } \\
\text { 1é851771 } \\
\text { MMAÉL.7. } 1885 \\
136 / 1867 \text { levélt. szám. } \\
\text { G } \\
\text { 99t175 d. rérééj8 tá. } \\
3 \\
\text { Nagyságos Királyi Tanácsos Úr! } \\
\text { aszthony Endre, Philipgopolisból } \\
\text { hazaérkezett, ménckvő, az Akadé- } \\
\text { mia kézirdttárába régebben } \\
\text { beküldött kéziratát: "az 1869-i } \\
\text { magyar menekültek története } \\
\text { Török országban" vagy a Tor- } \\
\text { ténelmi Bizottság által kiadat- } \\
\text { m vagy, hogy ő maga kiadhatsa } \\
\text { s ez által sanyára helyzeten } \\
\text { valamit könyethessen, el nem, } \\
\text { fogadás esetére visszak érvén; } \\
\text { a folyó hó 9-én tartott } \\
\text { osztályáles határozatábal } \\
\text { szerincsém vann e dolgozatat } \\
\text { áttenni a mondott Bizott- } \\
\text { sághozg véleményada } \\
\text { algosy. A nenyren pedig elö }\end{array}$ \\
\hline
\end{tabular}

2. kép Az első és a második modellel felismertetett levélrészlet

\footnotetext{
8 Digitalisierung \& Elektronische Archivierung (DEA). Hozzáférés: 2019. 03. 10. https://www.uibk.ac.at/germanistik/einrichtungen/dea.html

9 Recognition and Enrichment of Archival Documents. Hozzáférés: 2019. 03. 10 https://read.transkribus.eu/about/

10 Transkribus - How to Guides. Hozzáférés: 2019. 03. 10.

https://transkribus.eu/wiki/index.php/How_to_Guides
} 
Az átírásra szánt dokumentumokat kollekciókba kell gyüjteni, az egyes kollekciók igy számos dokumentumot tartalmazhatnak, mennyiségükre nincs megkötés.

A Transkribus - lehetöségeiböl és funkcióiból adódóan - tartalmaz optikai karakterfelismerő és kézírásfelismerő modult is. Egy feltöltött dokumentum feldolgozásának első lépése a megfelelő szegmentálás, azaza képfájlon lévőszöveg sorainak a beazonosítása és kijelölése. Megadható, hogy a dokumentum egészén vagy csak bizonyos oldalain menjen végbe a szegmentálás. A végeredmény szabad

\begin{tabular}{|l|c|c|}
\hline & Token & Karakter \\
\hline Elsỗ modell & $128 / 200$ & $276 / 954$ \\
\hline & $64 \%$ & $29 \%$ \\
\hline
\end{tabular}

\begin{tabular}{|l|c|c|}
\hline Második modell & $48 / 200$ & $116 / 954$ \\
\hline & $24 \%$ & $12 \%$ \\
\hline
\end{tabular}

1. táblázat A modellek tesztelésének hibaszázalékai

kézzel javitható, vagy teljes egészében pótolható, amennyiben az automatikus azonositás nem ment végbe megfelelően. Következő lépésként a kijelölt szegmentumokon futtatható az OCR vagy HTR, a feltöltött dokumentum jellegétöl függően. Kézirásfelismerés esetén szükséges egy modell kiválasztása is, amely az adott nyelv karakterkészleti sajátosságainak felismerésére lett létrehozva, és ami tanitható további feltöltött és hibátlanul átírt dokumentumok révén, ezzel növelve a hatékonyságát. A Transkribus angol és német nyelvre tartalmaz beépitett modellt, azonban kérhető bármely más nyelvre is, amennyiben megfelelő mennyiségü (min. 15000 átírt szó) ${ }^{11}$ és minőségü átírt dokumentum áll rendelkezésére. Az átírt szöveg végül számos formátumban exportálható: kétrétegü PDF, TEI, DOCX, TXT, stb.

\section{A korpusz}

Arany János hivatali iratainak összegyüjtése és feldolgozása az Arany János munkái kritikai kiadáshoz kapcsolódva 2014 szeptemberében vette kezdetét. A munka során eddig hol két, hol egy munkatárs tevékenysége révén kb. 2000 dokumentum betühiv, nyers átirata készült el, nagyjából 2400 oldal terjedelemben, részben .docx formátumban, részben a LyX dokumentum előkészitő rendszer kritikai kiadás készitésére alkalmassá tett, Hegedüs Béla által fejlesztett verziójában. Eközben befejezödött a hivatali iratok túlnyomórészt az MTA Könyvtár és Információs Központ Kézirattárában található anyagának szkennelése is, amely kb. 9200 dokumentumról nagyjából 30000 felvételt eredményezett. A Transkribus teszteléséhez ebből a jelentős mennyiségü anyagból került felhasználásra - ezen szöveg megírásáig 200 oldalnyi kézirat az Eötvös Loránd Tudományegyetem Bölcsészettudományi Kar Digitális Bölcsészet Központ kezdeményezésére és együttmüködésében.

11 Transkribus - Questions and Answers. Hozzáférés: 2019. 03. 10.

https://transkribus.eu/wiki/index.php/Questions_and_Answers 


\section{Tesztelés}

A teszteléshez két lépésben, 100-100 oldalnyi kézzel átírt - pontosabban a HTR eredményén javitott - levelet biztositottunk a szolgáltatás fejlesztőinek, a magyar nyelvre vonatkozó modell létrehozására és tanitására. Bár a Transkribus hivatalos leírása szerint már kb. 75 oldalnyi szöveg is elegendő lehet a tanulási fázishoz, a magyar nyelv esetében az első 100 oldalt követően csekély sikerrel tudott a modell boldogulni a kézírással. Teljesitménye összességében körülbelül 30\%-ra volt tehetö, ha nem vesszük figyelembe például a leveleken szereplö pecsétek szövegeit. Ezeket a modell szintén próbálta kiolvasni, gyakorlatilag eredménytelenül, amiben közrejátszott a pecsétek elhelyezkedése és árnyalata is.

A második körben biztosított további 100 oldalnyi átirattal azonban számottevően javult a modell teljesitménye. Nagyságrendileg csupán egy hibásan átírt szó fordult elő soronként. Fontos ugyanakkor megjegyezni, hogy mindegyikalkalommalazonos személytöl származó kéziratok átirataival ment végbe a fejlesztés. A cél viszont az, hogy a modell képessé váljon bármilyen magyar nyelvü kézírás felismerésére a lehető legkisebb hibázási aránnyal. Ennélfogva a tesztelés következő szakaszában egy másik személytöl származó, de időben ugyanakkor keletkezett kéziratok átiratát szolgáltatjuk a tanulási fázishoz.

Az 1. táblázat a két modell teljesitménybeli különbségeit mutatja számszerü és százalékos formában is. Egy tetszölegesen kiválasztott levélen le lett futtatva mindkét modell, a végeredményül kapott átiratokból pedig véletlenszerüen ki lett emelve ugyanaza 200 db token ${ }^{12}$. A táblázatból kiolvasható, hogy a modellek mennyi hibát ejtettek a tokenek szintjén, valamint a tokeneken belül a karakterek szintjén. Míg az első modell a mintának több mint felét (64\%) elrontotta, a karaktereknek pedig majd harmadát (29\%) nem tudta felismerni, addig a második modellnél ezek a hibaértékek valamivel több mint felére csökkentek. Fontos azonban megjegyezni, hogy ezek az arányok nagyon kis méretü mintát jelképeznek, nagyobb méretü, vagy akár a teljes átiratok összehasonlitása ezeket az arányokat valamelyest módosithatják.

\section{Konklúzió}

Az eddig összegyüjtött 9200 hivatali irat kiadása, nyomtatott kötetenként 700 dokumentummal számolva, 13-14 kötetben valósulhatna meg, ami a kritikai kiadások elkészitésének szokásos időtartamával - 8-10 év - kalkulálva, minimum 104 munkaévet venne igénybe. Ezt az időt pedig lerövidithetné egy kéziratátíróprogram használata, még akkor is, ha a program által elkészitett nyers átiratok ellenörzése, a hivatalos átírási elveknek való megfeleltetése, valamint a kritikai és magyarázó jegyzetek elkészitése továbbra is a textológusok feladata lenne. A kézzel irt karaktereket tehát némi betanitás után nagy hatásfokkal felismerni képes programjelentős segítséget nyújthat a szövegkiadásokelkészitésében, ám ez föként akkor lehet igaz, ha a szövegkiadó az eredeti írásképet leginkább megörző betühü

12 Szóköztöl szóközig tartó karaktersorozat 
átiratok készitésére törekszik, illetve, ha az átíró program felhasználói felületén a gép által készitett nyers átiraton a kivánt változtatások rögtön el is végezhetök, azaz az emlitett szövegszerkesztő alkalmas kritikai szöveg készitésére is.

Mindazonáltal a jelenleg - ingyenesen - elérhető online kézírásfelismerő és átíró szolgáltatásokközüla Transkribus bizonyula leghasznosabbnakaszövegfeldolgozás területén. Szabadon hozzáférhető, a lényeges eszközöket magába foglaló, nagyfokú teljesítményjavulásra képes szolgáltatás, amellyel még úgy is jelentős mennyiségü munkaórát tud megspórolni egy kutató, hogy az automatikus átírás végeredménye továbbra is ellenörzést igényel. Felhasználóbarát kialakitásának köszönhetően pedig egyedülálló a maga kategóriájában, szemben azokkal a szövegfeldolgozó alkalmazásokkal, amelyek informatikai és/vagy programozási háttértudást igényelnek a müködtetésükhöz, valamint grafikus felülettel sem rendelkeznek.

\section{Bibliográfia}

Arany János. „Hivatali iratok 2.: Akadémiai évek (1859-77)”. szerk., jegyz. Gergely Pál. Bp. Akadémiai K. (1964) (Arany János összes müvei, 14.)

Digitalisierung \& Elektronische Archivierung (DEA). Hozzáférés: 2019. 03. 10. https://www.uibk.ac.at/germanistik/einrichtungen/dea.html

Gergely Pál. „Arany János és az Akadémia.” Bp. MTA Irodalomtudományi Intézete Akadémiai K. (1957). (Irodalomtörténeti Füzetek, 11.)

Keresztury Dezső. „Csak hangköre más: Arany János 1857-1882.” Bp. Szépirodalmi K. (1987)

Optikai karakterfelismerés. Hozzáférés 2019. 03. 10.

http://szovegbanyaszat.typotex.hu/content/PDF/ch+ocr.pdf

Recognition and Enrichment of Archival Documents. Hozzáférés: 2019. 03. 10. https://read.transkribus.eu/about/

Transkribus. Hozzáférés: 2019. 03. 10. https://transkribus.eu/Transkribus/

Transkribus - How to Guides. Hozzáférés: 2019. 03. 10.

https://transkribus.eu/wiki/index.php/How_to_Guides

Transkribus - Questions and Answers. Hozzáférés: 2019. 03. 10.

https://transkribus.eu/wiki/index.php/Questions_and_Answers

Voinovich Géza. „Arany János életrajza 1860-1882.” Bp. Magyar Tudományos Akadémia (1938) 


\title{
Áttérés a Primo New User Interface használatára a Magyar Tudományos Akadémia Könyvtár és Információs Központban
}

\author{
Haász Antal \\ Magyar Tudományos Akadémia Könyvtár és Információs Központ \\ Szakinformatikai Osztály \\ haasz.antal@konyvtar.mta.hu
}

After the almost one year test-period, we have started to use the Primo NEW UI at the beginning of this year. The NEW UI is based on the modern web technologies. The study is about the main steps of migration: customizing of the opening page, and operational changes to the new library services.

Keywords: Primo, discovery system, web technology, API

\section{Bevezetés}

A Primo New UI bevezetésére - mintegy egy éves előkészitő fázis után - 2019 februárjában került sor az MTA KIK-ben.

A Primo használata nem volt előzmény nélküli könyvtárunkban, hiszen annak "classic" felülete már 2015 novembere óta elérhető volt felhasználóink számára. A rendszer általános jellemzőiröl illetve a 2015-ös bevezetés tanulságairól már egy korábbi tanulmányban beszámoltunk, ${ }^{1}$ ezért ezekröl itt most nem szólunk.

A továbbiakban részletesen ismertetjük az új verzióra (New UI) történő átállás meghatározó pontjait. Bemutatjuk a nyitóoldal - modern webes technológiákon alapuló - egyedi konfigurálásának föbb lépéseit, valamint azokat a müködéssel kapcsolatos fejlesztéseket, amelyekkel a hatékonyabb rendszerhasználatot igyekeztünk elősegíteni.

\section{A nyitóoldal kialakítása}

A munka kezdetekor az Ex Libris által biztositott, standard, minimális szerkezetiés dizájn- elemeket tartalmazó nyitóoldal állt rendelkezésünkre. A kitüzött cél az volt, hogy ezt a kezdetleges és „semleges” felületet egy egyedi, az intézményre jellemző szín- és formavilággal, valamint a felhasználói igényeket eredményesen kiszolgáló, dinamikusan müködő szolgáltatásokkal töltsük meg.

A munka elsősorban a szakinformatikusok és - a felhasználói szokásokat és igényeket leginkább ismerő - olvasószolgálati munkatársak együttmüködésében folyt. Folyamatos volt az egyeztetés a két osztály munkatársai között: ötletbörzék,

$1 \quad$ Haász, Antal. 2017. "A Primo használata a Magyar Tudományos Akadémia Könyvtár és Információs Központban." In Hagyományok és kihívások V. Múlt és Jövő, 167-178. doi: https://doi.org/10.21862/HagyKihiv_2016.167 
látványtervek elkészitése és véleményezése, hibalisták összeállítása, majd azok alapján történő javítások jellemezték ezt az időszakot.

A nyitóoldal konfigurálására a Primo Back Office felületén elérhető Customization Manager ad lehetőséget.

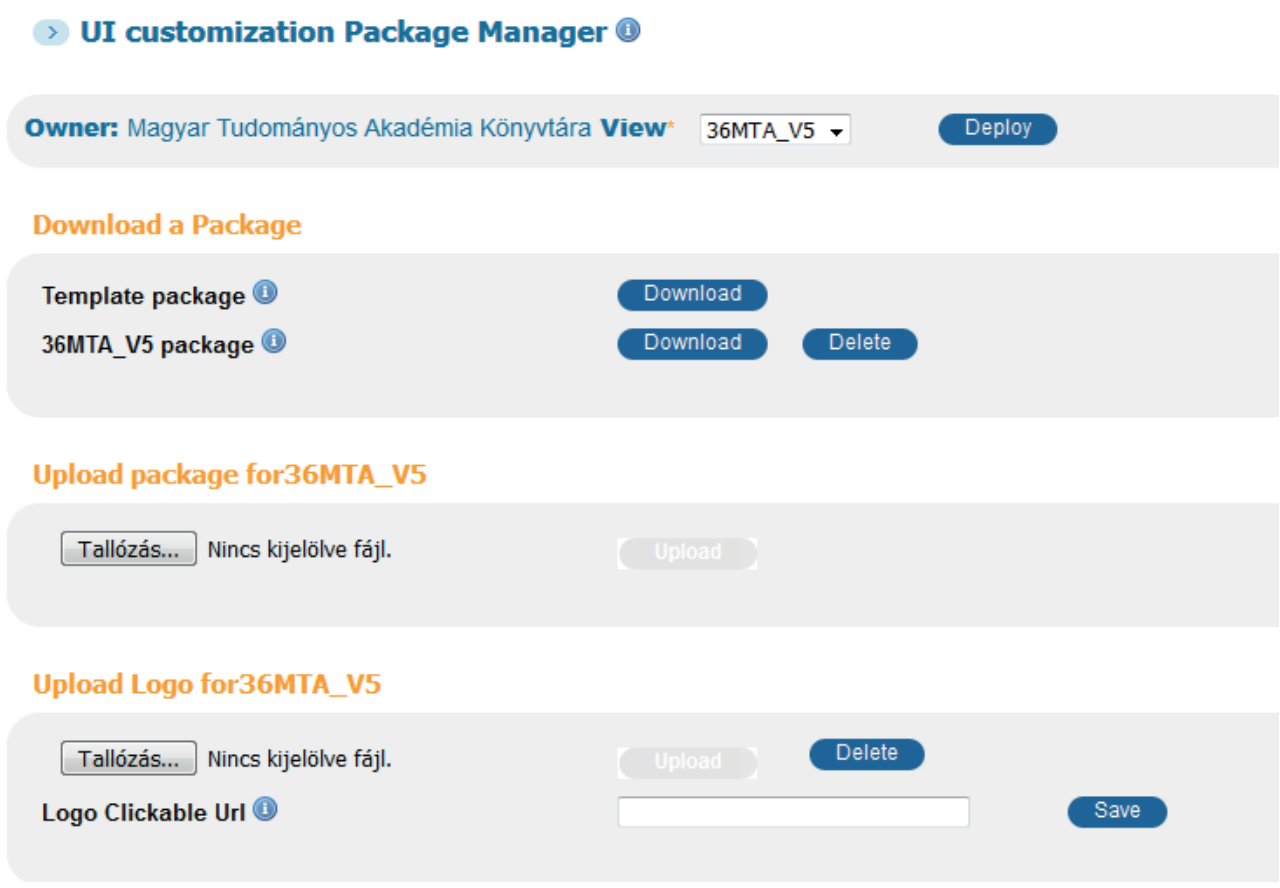

1. ábra A Customization Manager a Primo Back Office-ban

A Customization Manager-rel lehet az egyedi szerkesztéshez szükséges konfigurációs fájlokat és stíluslapokat letölteni, illetve a módosítás után azokat visszatölteni. Az úgynevezett Customization Package négy mappát tartalmaz. A HTML mappában érhetőek el nyelvenként a törzsoldal szerkezeti elemei (pl.: home_hu_HU.html), a CSS mappában található custom1.css fájl használatával lehet az egyedi szín- és formavilágot kialakitani. Az IMG mappába szükséges feltölteni a nyitóoldalon, illetve keresési felületeken használni kivánt képi elemeket (pl. librarylogo.png), továbbá a JS mappában található custom.js fájlban lehet JavaScript kódokat rögzíteni bonyolultabb webes megoldások alkalmazására.

Elsőként az egyedi fejléc kialakitásához fogtunk hozzá.

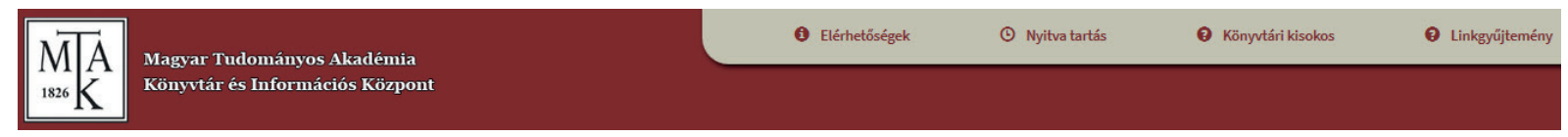

2. ábra A Primo egyedi fejléce az MTA KIK-ben 


\section{Haász Antal: Áttérés a Primo New User Interface használatára a Magyar Tudományos Akadémia Könyvtár és Információs Központban}

A munkát megkönnyitette, hogy a GitHub-on egy számunkra megfelelő menüszerkezetet leíró alap-kódkészlet volt elérhetö. ${ }^{2}$

A letöltött kód-részletet a custom.js fájlban kellett beilleszteni. Ugyanitt kellett létrehozni - html-kódolással - a megjelenitendö menüpontokat is. A könyvtári logo feltöltésével (IMG mappa) majd a könyvtári honlappal korreláló szinvilág kialakitásával (custom1.css) véglegesitettük az új verzió egyedi fejlécét.

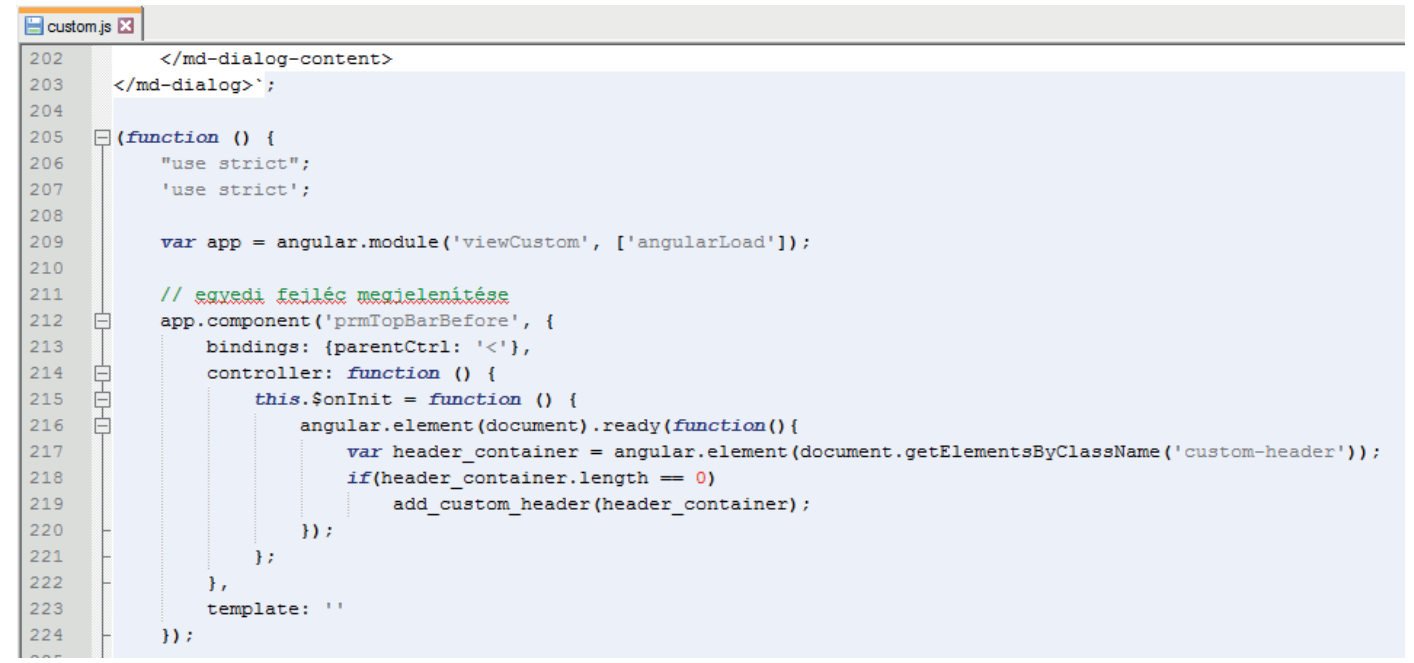

3. ábra A GitHub-ról letötltött kódrészlet a custom.js fájlban

Fontos szerepet szántunk az oldalon a hírblokknak, hiszen felhasználóink ezen keresztül tájékozódhatnak a könyvtárral kapcsolatos aktualitásokról. ${ }^{3}$

A „classic” felületre éveken keresztül "manuálisan”, egyenként megszerkesztve tettük fel a híreket. Ennek kiváltására kerestünk egy olyan új módszert, amely a meglévö hírforrások (könyvtári honlap, könyvtári hírlevél) alapján automatikus hírmegjelenést eredményez. A lehetöségek áttekintése után a megoldást a Primo és a könyvtári hírlevél (WordPress) közötti RESTful API-n alapuló kommunikációban találtuk meg. A müködés alapfeltétele volt, hogy a WordPress oldalon telepitve és engedélyezve legyen a REST API. A WordPress oldal kezelöjének továbbá feladata, hogy a Primo-n is megjeleniteni kivánt hírt egy meghatározott kategóriába (Primo) sorolja. A müködés során a Primo-ból egy úgynevezett HTTP GET kérés indul a Hírlevél felé, amely úgy van megírva, hogy az utolsó három, Primo-kategóriába sorolt hirt vegye át, majd jelenitse meg a kezdőoldal hir szekciójában. Mindezek eredményeképpen a Primo-ban folyamatos az automatikus hirátvétel a könyvtár hírleveléböl.

\footnotetext{
2 Hozzáférés: 2019.06.24. https://github.com/pdxlibrary/Custom-Header-for-Primo-Explore-Primo-NUI-

3 Mivel a könyvtári honlapon (https://konyvtar.mta.hu/) is folyamatos a könyvtárral kapcsolatos híradás, ezért megegyezés született arról, hogy a Primo-n elsösorban a katalógussal, az új könyvtári beszerzésekkel, adatbázisokkal kapcsolatos híreket szerepeltetjük, illetve csak a fontosabb nyitva tartási (pl. nyári szünet) információkat közöljük.
} 


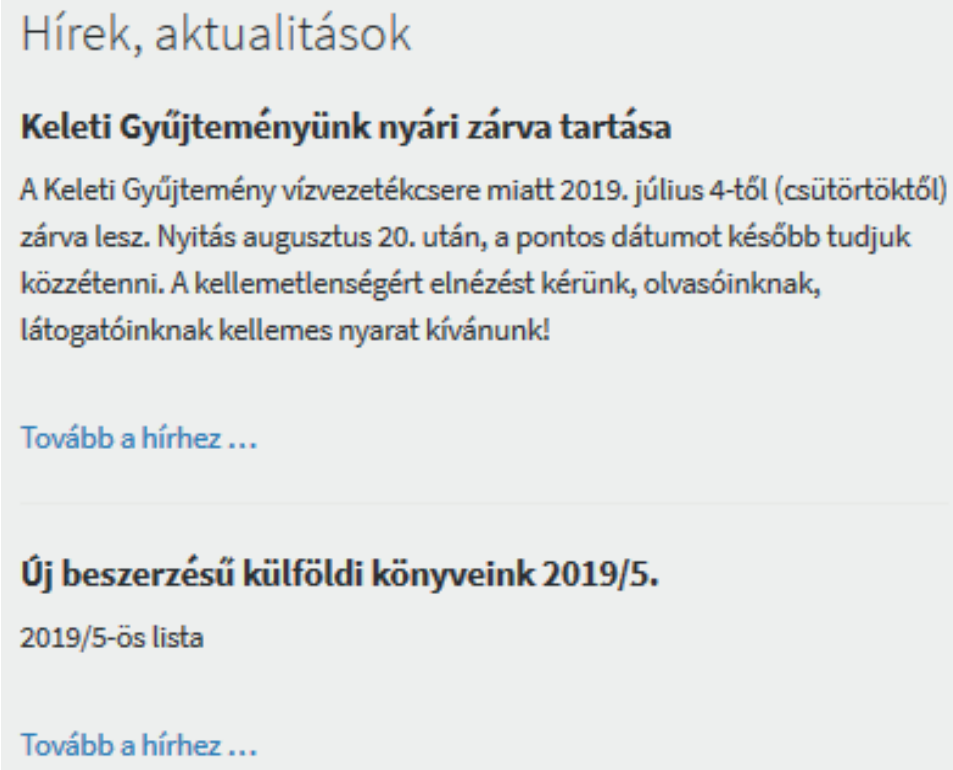

4. ábra Hírmegjelenítés a Primo-n

Könyvtárunkban folyóiratokra és különgyüjteményi dokumentumokra elökészitési igényeket lehet leadni. Igyekeztünk az igénylés folyamatát minél inkább leegyszerüsiteni. Ennek érdekében könnyen kezelhető ürlapokat terveztünk, amelyek révén olvasóink már a nyitóoldalról intézhetik lefoglalási kéréseiket.

Az ürlap kitöltése és elküldése után, a Primo HTTP POST kérést küld egy másik URL-re (work.mta.hu) JSON formátumban. A megszólitott szerveren a kérés hatására lefutnak a megfelelő php-scriptek, amelyek feldolgozzák a beérkező adatokat és e-mail értesítéseket küldenek ki egyrészt az olvasószolgálati munkatársaknak az új kérésről, másrészt a felhasználónak arról, hogy a kérés teljesitése folyamatban van.

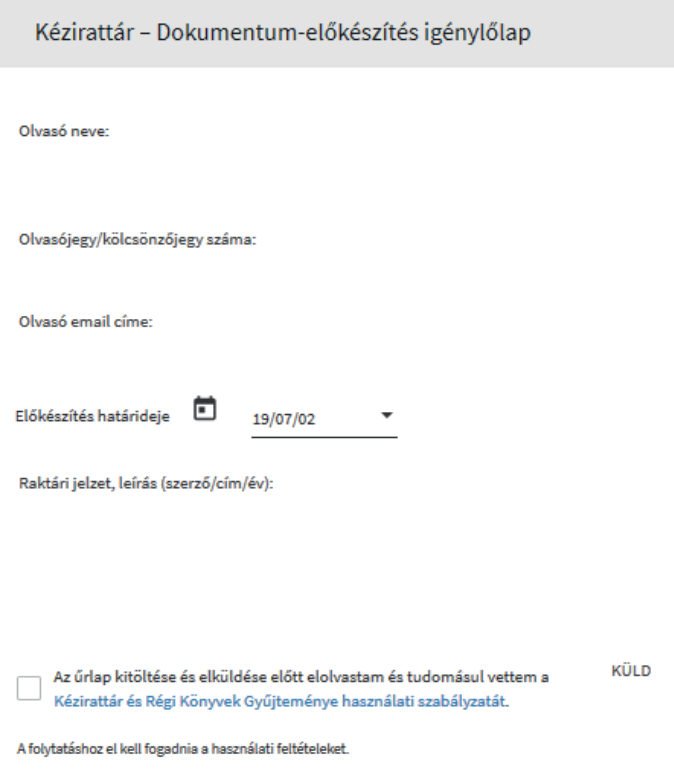


A fent bemutatott fejlesztések eredményeképpen megszületett a nyitóoldal azon verziója, ami most is - néhány kisebb módositással - használatban van.

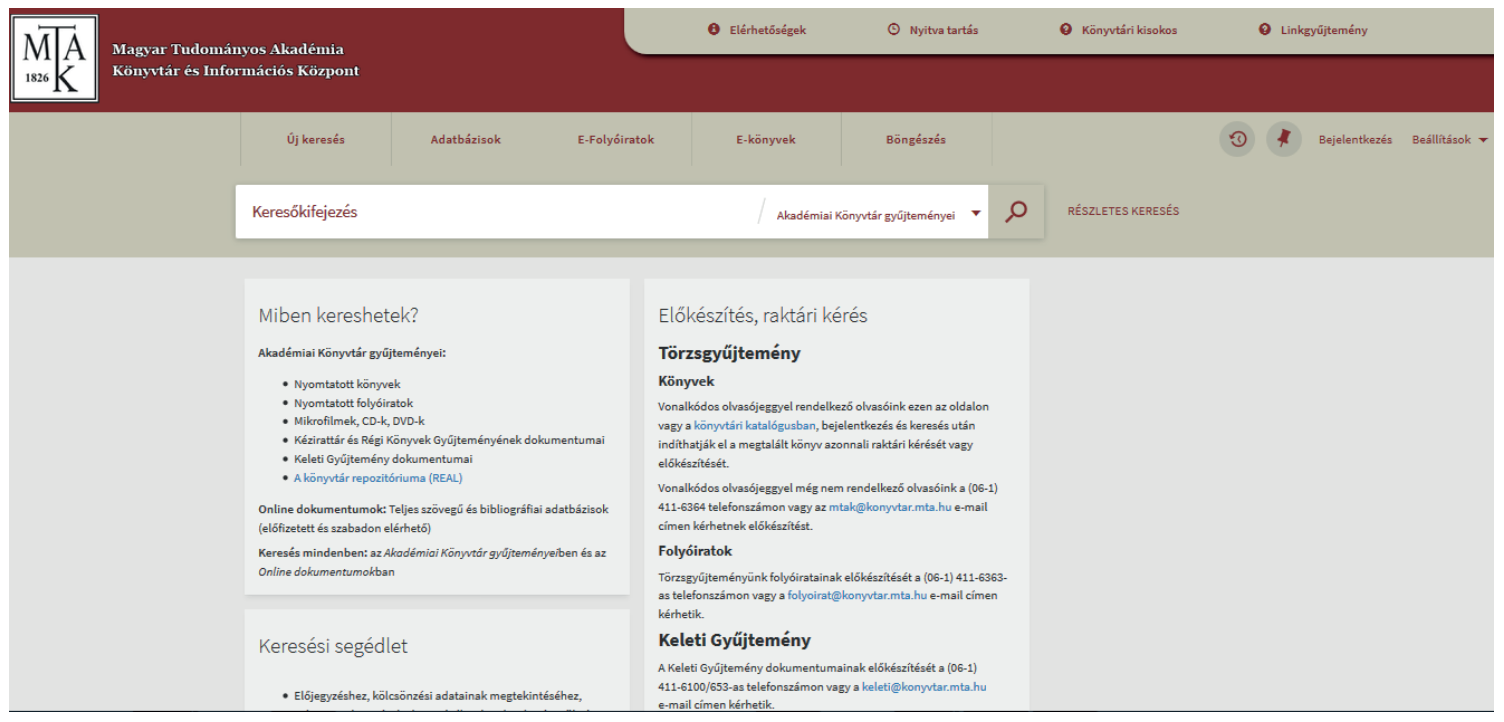

6. ábra Részlet a Primo nyitóoldalából

\section{A keresés és az adatmegjelenítés fejlesztése}

A Primo - mint a discovery rendszerek általában - lehetövé teszi a könyvtár teljes (hagyományos, elektronikus, illetve digitális) gyüjteményének egyidejü lekeresését. Az egyszerü (egymezős) keresés mellett lehetöségünk van részletes keresési adatok megadására, valamint böngészésre is. Kereshetünk csak valamely rész adatbázisban (scope) ${ }^{4}$ vagy választhatjuk az összes gyüjteményben való keresést.

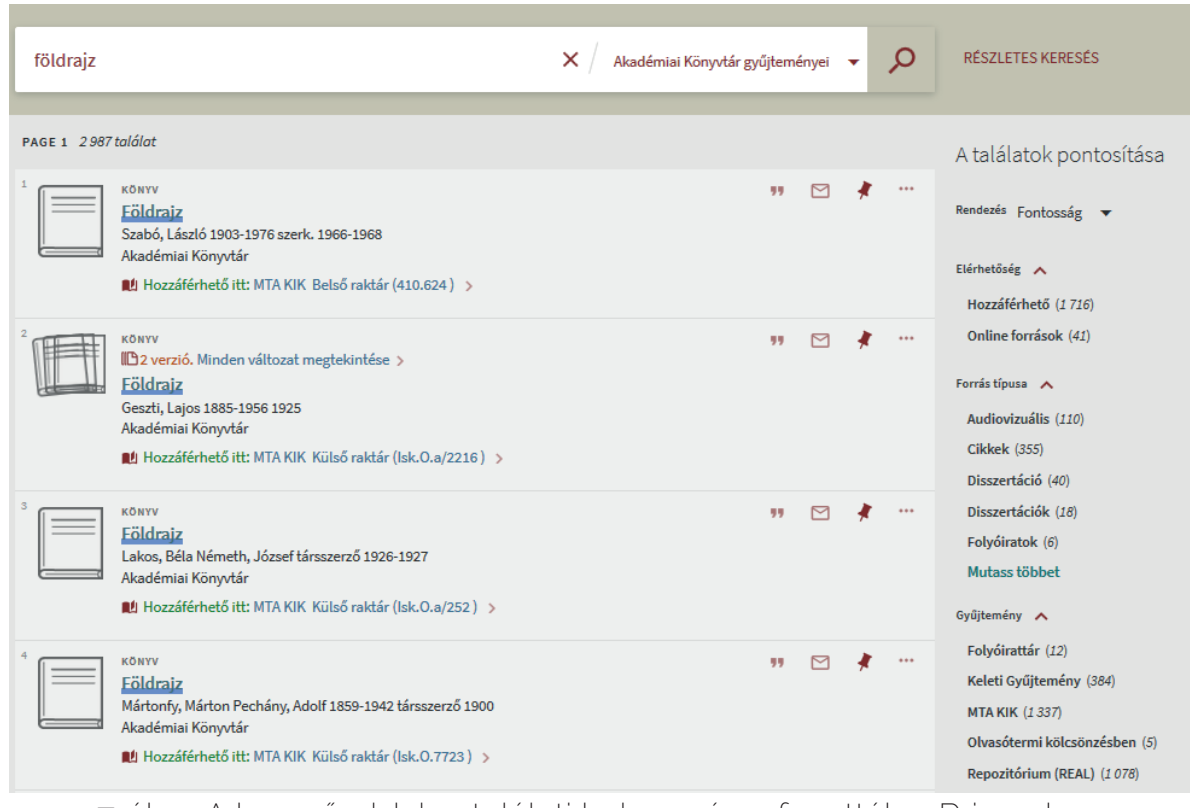

7. ábra A kereső oldal, a találati halmaz és a facetták a Primo-ban

4 Az MTA KIK Primo-jában két keresőcsoportot hoztunk létre: az Akadémiai Könyvtár gyüjteményei (ebben benne vannak a repozitóriumi dokumentumok is), valamint az Online dokumentumok csoportokat. 
A keresés lefolytatása után a Primo úgynevezett facetták alkalmazásával a találatokat rendezi, csoportosítja, ami - különösen a nagyszámú találati lista esetén - jelentősen növelheti a keresés hatékonyságát.

Tapasztalataink alapján a felhasználóink számára fontos szempont a dokumentum típusa alapján történő szükitési lehetöség. Ezért a New UI elinditásakor egy új, a dokumentum típusára utaló facetta bevezetését határoztuk el, amelyet "Forrás típusa" megjelöléssel használunk.

Könyvtári integrált rendszerünkben $(A L E P H)^{5} 2017$ márciusában tértünk át egy új dokumentumtipológia ${ }^{6}$ használatára. Az addig használt 7 formátum mellett, azok differenciált bontásával további 23 formátumot kezdtünk el használni.

Az új facetta müködését az átdolgozott dokumentumtipológia alapján kivántuk felépiteni.

Aleph-ben alapértelmezetten az FMT-mezöben jelenik meg egy adott bibliográfiairekord vonatkozásában a típus-információ. Emellett a rendszer lehetőséget kinál arra is, hogy ugyanezt az információt egy másik, úgynevezett TYP virtuális mezöben is tároljuk. A TYP mező a rekordok LDR, illetve 008-as mezőinek értéke alapján épül fel. ${ }^{7}$

A TYP-mező a rendszer-beállitások alapján az Aleph-rekordok publikálásakor átkerül a Primo-ba, így az MARC21/PNX8 mezömegfeleltetés alapjává tehető.

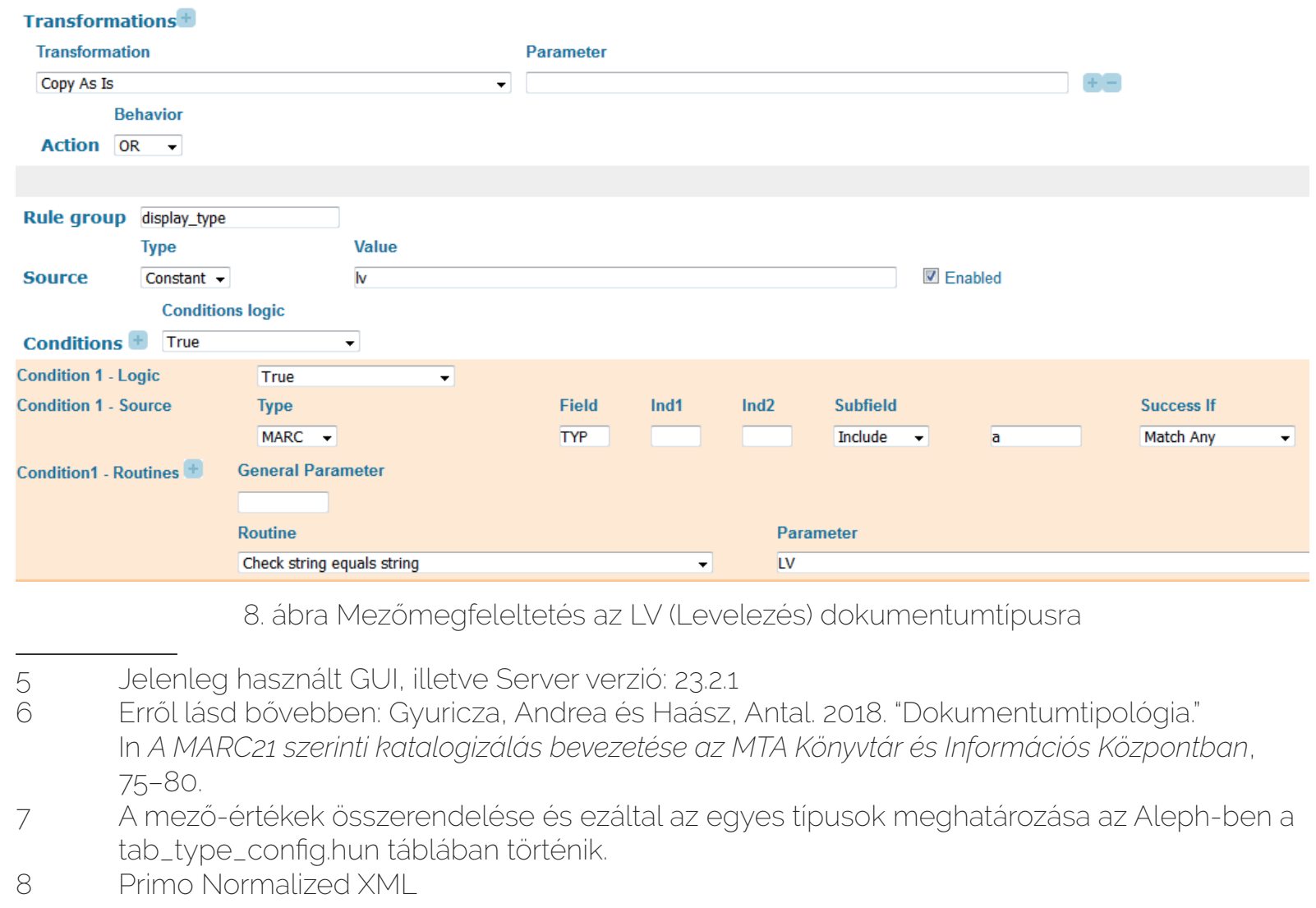




\section{Haász Antal: Áttérés a Primo New User Interface használatára a Magyar Tudományos Akadémia Könyvtár és Információs Központban}

Minden típushoz ikon is rendelhetö, amely a szöveges megjelölés mellett vizuálisan is megjeleníti az adott tétel formátumát.

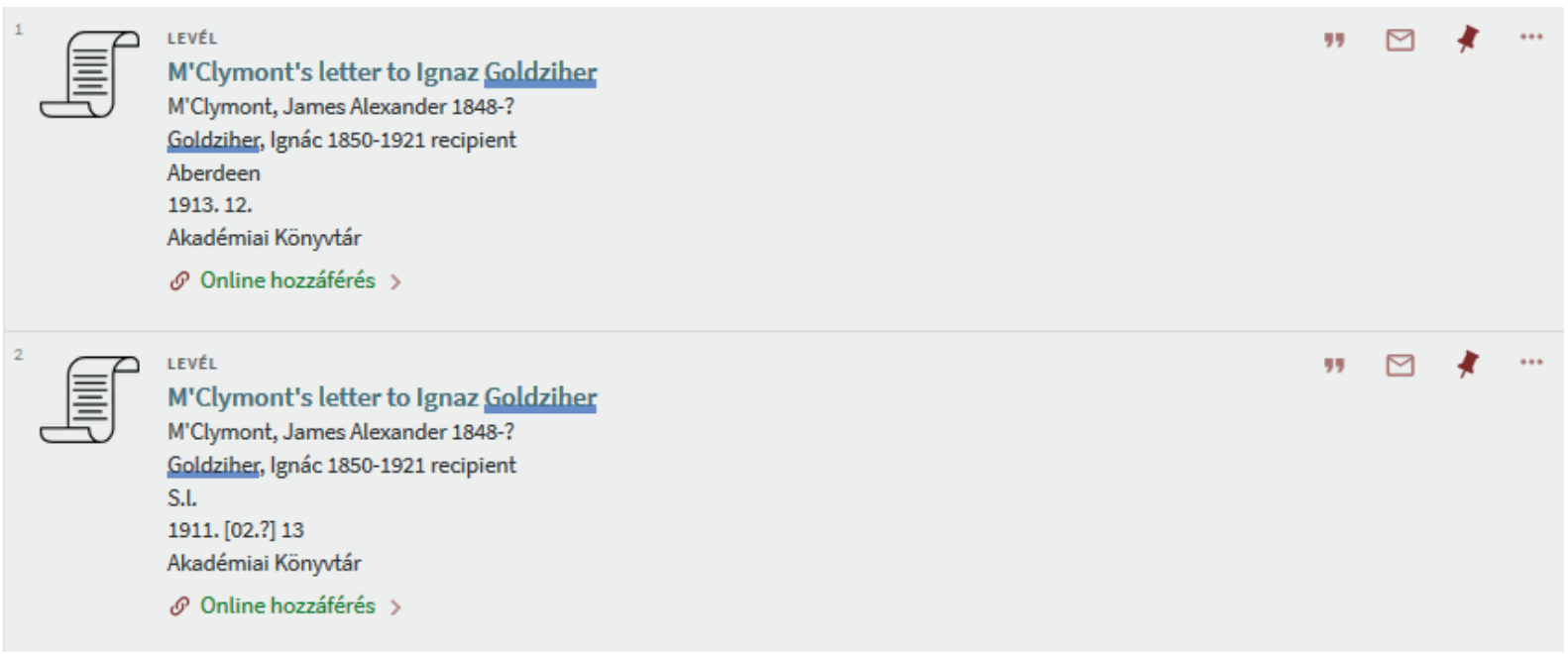

9. ábra Dokumentumtípus-megjelenités a Primo-ban

A leggyakrabban használt típusokra már elvégeztük a megfeleltetéseket, igy azok már láthatóak a Primo-ban. Terveink szerint a teljes dokumentumtipológia átültetésre fog kerülni a Primo-ban.

Azadatmegjelenités kapcsán mind a rövid, minda részletes nézetben módositásokat hajtottunk végre.

A találati listában zavaróan egymásra torlódtak a mü adatai, megnehezítve az áttekintést. A probléma megoldása érdekében minden adatcsoportot külön sorba helyeztünk, amit úgy értünk el, hogy Back Office vonatkozó részében mezőhatárolónak (delimiter) a <br> html-tag-et vettük fel.

A Részletek fülön jó néhány, tájékoztatási szempontból fontos adattartalom nem volt elérhető. Ezért - konzultálva az olvasószolgálatos és feldolgozó kollégákkal megkezdtük ezen adatok pótlását a felületen, amelyet szintén a már fent emlitett mezőmegfeleltetéssel végeztünk. A munka során megjegyzés (például 500, 502, $506,535,540)$, illetve folyóiratok állományadatait megjelenitő mezőket $(876,877)$ tettünk láthatóvá itt.

Az adatmegjelenités konfigurálása nem lezárt folyamat. Az igényeknek megfelelően bármikor vehetünk ki-, illetve tehetünk be adatcsoportot a felhasználói felületekre.

\section{Raktári kérés a Primo-ban}

A Primo-ban az előjegyzés funkció használatával valósitottuk meg az online raktári kérés lehetőségét. A klasszikus értelemben vett előjegyzési funkció ${ }^{9}$

9 Kölcsönzésben lévő dokumentumra - általában külön dij ellenében - leadható foglalás. A dokumentum visszaérkezéséröl a könyvtár értesiti a foglalást kezdeményező olvasót és megadott ideig félreteszi számára a kért dokumentumot. 
használata könyvtári gyakorlatunkban nincs (és nem is volt) jelen (csak raktárban lévő dokumentumra lehet elöjegyzést tenni, kölcsönzésben lévöre nem). Ezért esetünkben helyesebb inkább előkészitési vagy lefoglalási rendszerröl beszélni. Ennek megfelelően kellett a Primo-ban is kialakitani az előjegyzési rendszert, módositva az eredeti beállításokat.

A kölcsönzésben lévő dokumentumok előjegyzésének blokkolását Aleph beállitásokkal tudtuk megoldani a Primo-ban is. ${ }^{10}$ Egy paraméter-tábla egyik ellenőrzési procedúrájával ${ }^{11}$ - a megjelölt olvasói státuszok esetében - a kölcsönzéseket tartós kölcsönzéssé lehet minösiteni, amelyekre nem lehet elöjegyzést tenni. Ebben a táblában az összes olvasói státuszt felsoroltuk, így gyakorlatilag - a célnak megfelelöen - az összes kölcsönzött dokumentum vonatkozásában blokkoltuk az előjegyzési lehetőséget.

Ezek után a megfelelő előkészitési ürlap kialakitása következett. Az átvétel helyének kiválasztása, az érdeklődés maximális dátumának megadása, illetve a helyszám (amennyiben a kérö az olvasóteremben tartózkodik) kitöltése után véglegesíthető (kérés küldése) az ürlap. Opcionálisan megjegyzési szöveg is csatolható a kéréshez. Az igénylés teljesitése egy-két munkanapot vesz igénybe (attól függően, hogy külső vagy belső raktári kérésröl van szó).

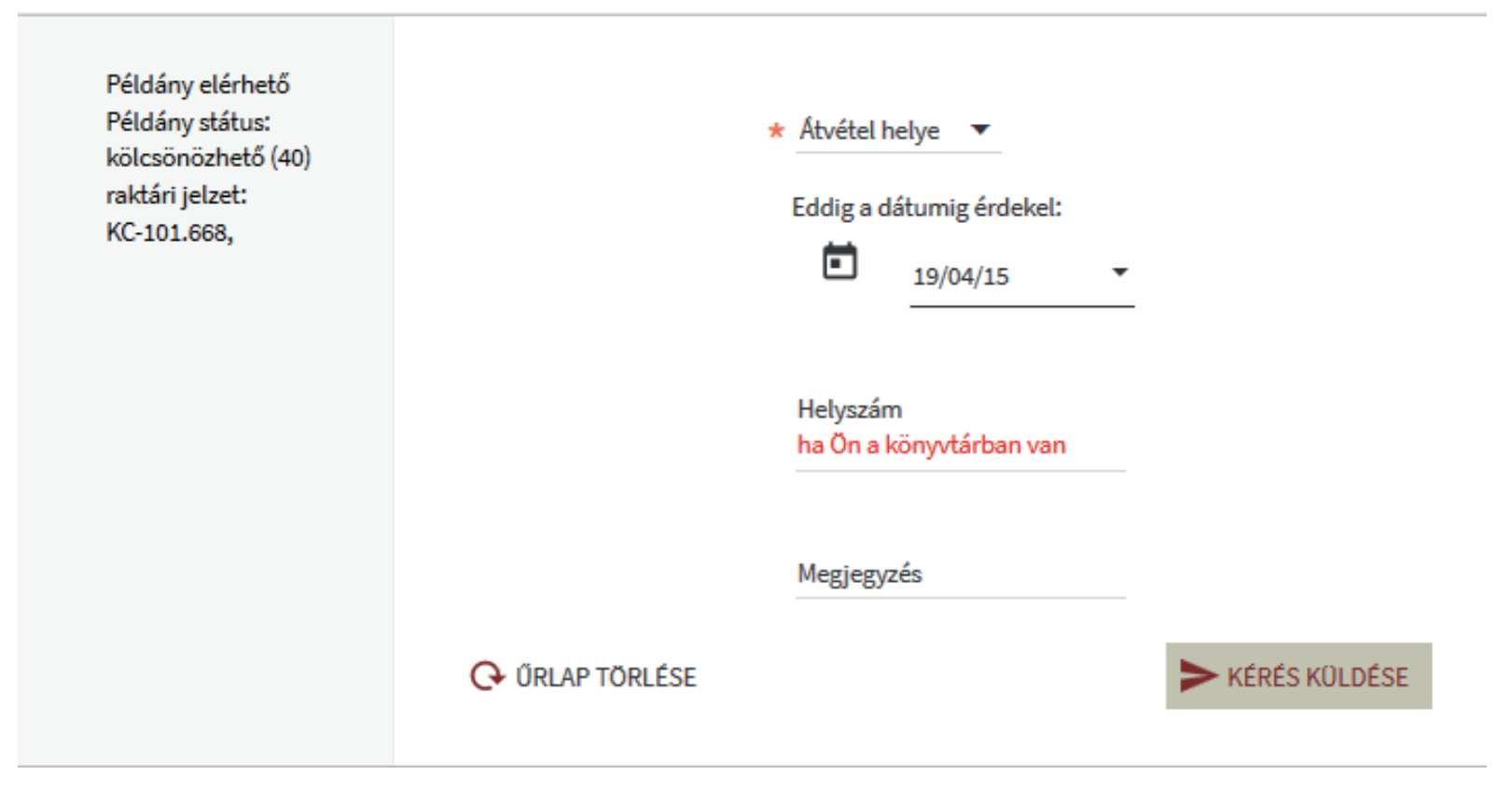

10. ábra Az előjegyzési ürlap a Primo-ban

\footnotetext{
10 A Primo a kölcsönzési - ezen belül az elöjegyzési - funkciók vonatkozásában a könyvtári rendszer (esetünkben az Aleph) beállitásait használja.

11 Ez a tab_hold_request tábla és a check_hold_request_w procedúra.
} 
Az olvasóknak szánt tájékoztató szövegeket egységesitettük, minden képernyőképen a „Raktári kérés” megnevezéssel jelöltük az előjegyzési funkciót. Abban az esetben, ha az adott müre nem lehet elöjegyzést tenni, igyekeztünk minél lényegre töröbben tájékoztatni a felhasználóinkat a továbblépés lehetőségéröl („Ez a dokumentum valószínüleg különgyüjteményben található. Forduljon a könyvtároshoz.").

\section{4. Összegzés}

A tesztelési időszak, valamint a közel fél éves éles müködés tapasztalatai alapján megállapitható, hogy az új verzió - elsősorban reszponzivitásából eredően - sokkal több lehetőséget rejt a felhasználóbarát felületek kialakitása terén. Fontosjellemzője az egyedi konfigurálhatóság, amely számos speciális szolgáltatás elinditását teszi lehetővé.

A rendszerben rejlö lehetőségek kiaknázása érdekében elengedhetetlen a dokumentáció áttekintése, a könyvtári rendszerrel való kapcsolatok feltérképezése.

Végezetül szeretném megköszönni Lovas Bálint informatikus kollégámnak a nyitóoldal kialakitásában végzett kitartó és ötletgazdag munkáját, valamint azokat az értékes információkat, amikkel segítette a tanulmány megírását. 


\title{
Nyílt publikálási szoftverek és platformok
}

\author{
Holl András \\ MTA Könyvtár és Információs Központ \\ holl.andras@konyvtar.mta.hu \\ ORCID: 0000-0002-6873-3425 \\ Bilicsi Erika \\ MTA Könyvtár és Információs Központ \\ bilicsi.erika@konyvtar.mta.hu \\ ORCID: 0000-0003-2651-2955
}

\section{Open publication software and platforms}

The use of open journal publishing software (mainly the Open Journal Systems and its „siblings") is spreading in Hungary. There are individual installations and platforms which serve several journals. We survey the present usage, and deal with the role of such software platforms for libraries and academia. With the availability of open source, free content management systems developed for scholarly communication, which offer compliance with standard aggregation protocols, small, independent scholarly journals might become more visible.

Keywords: open access, open source, Open Journal Systems (OJS)

\section{Bevezető}

Tanulmányunkban a hazánkban is egyre gyakrabban alkalmazott, ${ }^{1}$ nyilt forráskódú szoftveren alapuló, szabványos protokollokat használó, jellemzően nyilt hozzáférésü közleményeket publikáló platformokkal foglalkozunk, elsősorban könyvtárosi szempontból.

Figyelmünket az Open Journal Systems-re (OJS) összpontositjuk, ám kitérünk "testvéreire" - az Open Conference Systems-re ${ }^{3}$ (OCS) és az Open Monograph Press-re ${ }^{4}$ (OMP) - és "rokonaira" is. Kidomboritjuk azt a szerepet, amit ezek a rendszerek az információ-keresésben és a bibliográfiák készitésében játszhatnak. Példákat mutatunk be a DOI-regisztráció, a Magyar Tudományos Művek Tára (MTMT) számára történő adatátadás és a repozitóriumi kapcsolat megvalósitásáról.

Nem csupán a nagy kiadóvállalatok jelentetnek meg tudományos mủveket fontos közlemények jelennek meg nem kereskedelmi alapon müködö szervezetek (tudományos társaságok, egyetemek, kutatóintézetek kiadói vagy független kiadók) gondozásában. 2017-ben az MTMT szerint a hazai szerzők cikkeinek közel

\footnotetext{
1 A Magyarországon müködő OJS-ben megjelenő folyóiratok listája, Hozzáférés: 2019.07.02. http://openaccess.mtak.hu/index.php/103-openjournalsystems/155-ojs-hazai-kiadvanyok Open Journal Systems, Hozzáférés: 2019.07.02. https://pkp.sfu.ca/ojs/ Open Conference Systems, Hozzáférés: 2019.07.02. https://pkp.sfu.ca/ocs/ Open Monograph Press, Hozzáférés: 2019.07.02. https://pkp.sfu.ca/omp/
} 
harmada olyan folyóiratban jelent meg, amelyet nem követ sem a Web of Science (WoS), sem a Scopus. A WoS vagy Scopus indexelés, jelentsük ki, nem jelent feltétlenül minőségi itéletet: a nem világnyelven közlö, nem kellő rendszerességgel megjelenő, kis példányszámú, inkább csak helyi jelentőségü lapok is közölnek értékes cikkeket. A nemzeti vagy regionális jelentőségü kutatások esetében nehéz a közleményeket nemzetközi folyóiratokban elhelyezni.

Az ismertetett nyilt forráskódú platformok - bár alkalmazzák ezeket egyes kiadóvállalatok ${ }^{5}$ is - jellemzően kis, független (indie) folyóiratokat szolgálnak ki. Az indie kiadványoknak mind a hosszú távú túlélése veszélyeztetett, mind a láthatósága korlátozott (gyakorta a méretük, nyelvük miatt nem kerülnek be a nagy, kereskedelmi alapon müködö bibliográfiai adatbázisokba). Különös fontossága van az elöbbieknél fogva a repozitóriumi archiválásuknak és a közös keresőkbe való indexelésüknek.

A független folyóiratok kiadói tanszékek, intézetek, tudományos társaságok, helyi kiadók. Ezek a múltban nem élvezhették a nagy, kereskedelmi indexelő adatbázisok jótéteményeit. Cikkeiket csak nemzeti bibliográfiai és archiváló rendszerek - mint a mi MATARKA-nk vagy EPA-nk - vagy szük szakterületeket lefedő bibliográfiák dolgozták fel. Az ezekben a cikkekben megjelenő hivatkozások feldolgozása azonban már meghaladja a lehetöségeket - mint azt az e téren történt hazai próbálkozások kudarca bizonyitja.

A WoS és a Scopus eredetileg kézi erövel, késöbb már egyre inkább gépileg dolgozta fel az indexelt folyóiratokban megjelenő cikkek adatait. Ez jelentős befektetést igényelt, amit a szolgáltatások nemzetközi értékesítése tett kifizetödővé (magas haszonkulcs, azaz magas árak mellett).

Ma már azonban az informatika lehetővé teszi, hogy a kis, független folyóiratok analitikus feltárása és a bennük közölt idézetek (többségének) feldolgozása is megtörténhessen - automatikusan. Ehhez arra van szükség, hogy a cikkek adatbázis alapú informatikai rendszerben kerüljenek feldolgozásra és a hivatkozások DOI azonositókkal legyenek ellátva. A tudományos kommunikáció modern technikai infrastruktúrájának müködtetése (keresők/aggregátorok üzemeltetése, hivatkozások gyüjtése) is pénzbe kerül, de lényegesen olcsóbban megoldható, mint a korábbiakban (pl. Web of Science, Science Citation Index). Ezért tökeszegény szakmai szervezetek is nyújthatnak ilyen szolgáltatásokat, a kereskedelmi alapon müködő, ilyen technológiákat alkalmazó vállalkozások pedig olcsóbban tudják (és kénytelenek) adni szolgáltatásaikat. A tudományos kommunikáció világában az új lehetőségek új szolgáltatások, eszközök burjánzásához vezetnek és esélyeket adnak az indie folyóiratoknak is.

$5 \quad$ Az Akadémiai Kiadó az OJS kézirat-beküldési funkcióit használja. 


\section{Publikációs platformok - az Open Journal Systems}

A kiadók, szerkesztőségek számos dijfizetés ellenében használható ${ }^{6}$ és nyilt forráskódú7 publikációs platform közül választhatnak.

A Public Knowledge Project (PKP) szabad forráskódú publikálációs platform szoftverei a folyóirat-szerkesztőségi müködést, publikálást és adminisztrációt automatizáló Open Journal Systems, a konferencia-szervezést és a konferenciakiadvány közreadását szolgáló Open Conference Systems, valamint a könyvkiadást támogató Open Monograph Press. ${ }^{8}$ Az említett publikációs platformok mellett a PKP egy aggregátor-szoftvert is közread: ez az Open Harvester Systems. ${ }^{9}$

A PKP szoftverei a kis létszámú szerkesztőségek részére tökéletesen megfelelő szolgáltatásokat és konfigurálási lehetöségeket nyújtanak. Telepítésük és üzemeltetésük viszonylag egyszerü, de a tapasztalatok azt mutatják, hogy az üzemeltető informatikus mellett mindenképpen szükség van egy informatikai érdeklődéssel rendelkező szerkesztőségi tagra, vagy a szerkesztőséget segítő helyi könyvtárosra, informatikusra, aki az ún. folyóiratmenedzseri feladatokat ellátja. A folyóiratmenedzser jogosult az OJS-ben a weboldal megjelenését testreszabni, a lap munkafolyamatának megfelelő beállításokat (pl. rovatok, melléklet típusok, határidők, lektorálási ürlap, alapértelmezett e-mailek szövege) megtenni, de ez a személy hivatott arra is, hogy segitse a szerkesztöségi tagok és a szerzők munkáját, ha technikai nehézségbe ütköznek a szoftver használata során. Ez pedig garantáltan előfordul, hiszen egy igen sokrétü munkafolyamat támogatására hivatott szoftverről van szó, ami a cikkek benyújtásától a lektorálási, tördelöszerkesztési munkafolyamatokon át az online megjelentetést, de még az utólagos adminisztrációs feladatokat is (mint például a DOI regisztráció) automatizálhatóvá teszi.

A nyilt, adatbázis alapú, szabványokat támogató publikációs platformok nem elsősorban a kiadók munkáját könnyitik meg. Nem mindig könnyű megtanulni ezen szoftverek használatát az e-mail és a kockás füzet után. Nehéz elviselni a szoftverek által megkivánt szabatosságot, elvágólagosságot. Leginkább abban jelentkezik az elönyük, hogy alkalmazásukkal könnyebb az információáramlás az adatbázisok között - a könyvtárosok és persze, végül az olvasók a haszonélvezök.

Atudományos kommunikáció nemzetközi hálózatábavaló bekerülést nagyban segíti az adatbázis alapú publikációs szoftverek használata. Ezek lehetőséget adnak az automatikus információátadásra, az új technológiájú információ-aggregátorokhoz

\footnotetext{
6 például: HighWire Press, Atypon, ubiJournal, Scholastica, ManuscriptManager, JMS például: OJS, Libero, Janeway, Ambra Az OJS-röl és az MTA KIK-ben való alkalmazásáról Payer Barbara tartott előadást a Networkshopon 2017-ben. Payer Barbara: A megújuló online folyóiratkiadás. Tudásmegosztás, együttmüködés, automatizálás. Networkshop 2017: TMT 64. (2017) 11. 548. Hozzáférés: 2019.07.02. http://tmt.omikk.bme.hu/tmt/article/view/1330/10363

9 Open Harvester Systems, Hozzáférés: 2019.07.02. https://pkp.sfu.ca/ohs/
} 
való kapcsolódásra ${ }^{10}$. Mindeközben természetesen a hagyományos kereskedelmi adatbázisokba is könnyebb bekerülni a megfelelő technológiák alkalmazásával.

Az alábbiakban áttekintjük a PKP platformjainak néhány olyan tulajdonságát, amelyek lehetővé teszik a bibliográfiai információk áramlását. Ezeket mi elsősorban az OJS esetében alkalmazzuk, de adott esetben müködnek a másik két szoftverben (OCS, OMP) is.

\section{Bibliográfiai adatok szüretelése}

Mind az aggregáció, mind a különböző rendszerek összeköthetőségének fontos eszköze az OAI-PMH ${ }^{11}$. Az aggregátorok, mint a BASE, Core vagy éppen a magyar Repozitóriumi Közös keresö12 (OAlkereso) nem csupán repozitóriumokat, de más OJS-t támogató platformokat is aggregálhatnak. Az OAlkereso jelenleg 55 OJS vagy OCS periodika adatait aratja. Folyóirat publikáló platformot üzemeltet Magyarországon többek között az MTA Könyvtár és Információs Központ, a Szegedi Tudományegyetem, a Debreceni Egyetem, a Pécsi Tudományegyetem, a Nemzeti Közszolgálati Egyetem, valamint a Corvinus Egyetem.

\section{MTMT feltöltés, repozitóriumi archiválás}

Mivel az OJS-ben tárolt adatok könnyedén legyüjthetöek az OAI-PMH protokoll segítségével, egy erre épülő, ún. OAluploader, azaz cikkfeltöltő alkalmazás készült az MTA KIK számára. Az eszköz müködésének kulcseleme a megfelelöen konfigurált OAl kimenet - ill. természetesen a mezők megfelelő adatokkal való kitöltése.

Az alkalmazásba az MTMT „Kiadók” intézményének adminisztrátorai léphetnek be. Akár az adatbázisukban tárolt összes cikk adatait betölthetik az eszköz segítségével az MTMT-be, de szükithetnek az adott folyóirat konkrét évfolyamára, füzetszámára, azon belül akár egy konkrét rovatra is. Az általunk elképzelt ideális munkamenet az lenne, ha a megjelenést követöen a lehetö legrövidebb idön belül elvégeznék ezt az adatfeltöltést, hiszen ez biztosítaná, hogy a szerző munkásságában az ő közremüködése nélkül vagy legalábbis közremüködésének minimalizálásával kerülhessenek be a cikkek. Azaz a fejlesztés során az egy folyóiratszámra való fókuszálás volt a cél amellett, hogy az adminisztrátorok munkájának egyszerüsitését is szem elött tartottuk. Ennek érdekében az OAluploader-ben azokat az adatokat, melyek minden folyóiratszámban megegyezőek, tároljuk egy ún. folyóirat ürlapon. Így nem szükséges minden egyes feltöltés megkezdésekor megadni a folyóirat ún. OAI base URL-ét és beállitani az adatfeldolgozási sémát, ill. kiválasztani az MTMTben tárolt listából a folyóirat címét, nyelvét és a kapcsolódó tudományágat, hiszen ezek minden cikk esetén megegyezö adatok lesznek (pl. a Földtani Közlöny folyóirat vélhetően földtudományi cikkeket közöl, így ez a szakterület beállítható, de a szerző

\footnotetext{
10 Új nyilvános kereső szolgáltatások: Dimensions, Lens, 1Findr, Scilit, Science Open. Akadémiai aggregátorok: CORE, BASE. Háttér infrastruktúrák, technológiák, adatbázisok: DOI CrossRef, DataCite: OpenAccess információ párositása DOl-val: oaDOli Unpaywall: szerzőazonositás: ORCID, technológiák: SHARE. A felsoroltak között vannak olyanok, amelyeket már valamelyik multi felvásárolt, vannak startupok, vannak közösségi "szövetkezeti" szervezetek

11 Protocol for Metadata Harvesting. https://www.openarchives.org/pmh/

12 http://oaikereso.sztaki.hu/kereso/index.php
} 
finomithatja, ha a cikk bekerült a munkásságába). A müködés kulcseleme a séma beállítása, ami az adott folyóiratból kinyert adatok feldolgozásának szabályozására szolgál. Az adatokat a 'source' mezö tartalmazza, az egyes adatok felismeréséhez egy ún. sémát kell megadni az alkalmazásnak.

\section{Segitség a séma megadásához}

\section{Séma:}

Adott OAl repozitóriumhoz tartozó adatok feldolgozására szolgál.

Az adatokat a lekért rekord source mezője tartalmazza.

Itt megadhatja a source mezô kulcsszavak általi leírását.

\section{A kulcsszavak az értékek helyét jelölik.}

PUB: folyóiratneve

VOL: évfolyam

NUM: füzet

DATE megjelenés éve

RAN: kezdő és záró oldalszám

Figyeljen a kulcsszavakat közötti karakterek pontos megadására!

\section{Példa:}

Az alábbi source mezô esetén:

Dissertationes Archaeologicae; Ser. 3, No. 3 (2015); 191-202

Az elkészített séma:

PUB; Ser. VOL, No. NUM (DATE); RAN

1. ábra: A metaadat-megfeleltetés sémájának beállitása az OAluploader szoftverben

A keresést követően megjelennek az adott számban megjelent cikkek. Sajnos duplumszürés nincsen a rendszerben, ezért az adminisztrátorok feladata, hogy ellenőrizzék, hogy az MTMT-ben szerepel-e esetleg már a feldolgozandó füzetszámban megjelent cikk. Ha igen, akkor azt nem szabad feltölteniük, ill. ha mégis feltöltik, azt az MTMT-ben duplumösszevonással kezelni kell. Miután kijelölték a feltöltendő cikkeket, a többit már nem viszi tovább a következő munkafolyamatba a rendszer. A következő oldalon megjelennek a folyóirat ürlapján beállított fix adatok, amiken még lehet módositani, ezek minden cikk adatlapjára be fognak kerülni. Ezután pedig cikkenkénti szerkesztésre van lehetőség egy MTMT-hez hasonló felületen, ahol az egyes cikkek adatai javithatóak, ha erre szükség van, ill. gazdagithatóak olyan adatokkal, amiket a folyóirat platform nem tárol (pl. szerző egységesitett neve az MTMT-ben, affiliáció). Ezután inditható a feltöltés, ami az MTMT-be és a REAL-ba is feltölti az adatokat, a repozitóriumba a teljes szövegü PDF-fel együtt, valamint az ott létrejött linket beirja az MTMT-be az OA státusszal együtt. A DOI is bekerül az MTMT-be, tehát elöbb érdemes azt regisztrálni. 
Az alkalmazás bármilyen, megfelelően konfigurált OAl kimenetü forrást támogat, nem csak az OJS platformon megjelenő lapok feltöltését.

\section{További adatcserét támogató funkciók}

A cikkeiket DOI azonositóval ellátó folyóiratok egy ügynökség (leginkább a CrossRef) adatbázisába is feltöltenek az azonositó regisztrációjakor metaadatokat. Ezek az adatbázisok is egyre inkább szolgálják a cikkek láthatóságának növelését. Az OJS DOI pluginja segiti a CrossRef és DataCite azonositók regisztrálását.

Az OJS támogatja az ORCID API-n keresztül hitelesitett azonositó regisztrációt. Az ORCID azonositók pedig továbbkerülhetnek a CrossRef DOI metaadat-tárába.

Az emlitetteken túl az OJS bővitmények léteznek a PubMed, a DOAJ, a COUNTER ${ }^{13}$, valamint a LOCKSS ${ }^{14}$ adatcsere támogatására. CrossRef-tag folyóiratok számára rendelkezésre állnak kapcsolódási lehetöségek a hivatkozáskövetés (cited by), plágiumellenörzés és verziókövetés támogatására.

\section{Folyóirat- és konferencia hosting az MTA Könyvtár és Információs Központban}

Jelenleg 23 folyóirattal vagyunk kapcsolatban, hat folyóirat jelenik meg az OJS platformunkon. Van olyan folyóirat, amelyik a folyamatszervezési funkciót használja, de más (saját) felületen publikál. Mindezek közülösszesen ketten használják a teljes funkcionalitást.

Az MTA KIK a korábban indított OJS folyóirat-platformhoz hasonlóan OCS platformot létesitett. Ez a platform ad otthont a Hungarnet Networkshop konferenciasorozat kiadványa számára - de a konferencia bonyolitása jelenleg nem ebben a rendszerben történik. Sajnos, az OCS szoftver új verziójának megjelenése évek óta várat magára - ez nehézségeket okoz a platformunk müködtetésében.

\section{Más hasonló szoftverek, szolgáltatások folyóirat-kiadáshoz és konferenciaszervezéshez}

Bár a független kiadók körében ez a legelterjedtebb, nem csupán a PKP szoftverei állnak rendelkezésükre. Nem is a szoftver gyártója a lényeg, hanem az, hogy a bibliográfiai adatok adatbázisban - vagy más módon -, gépileg hozzáférhetőek legyenek, a platform támogassa a szabványos protokollokat (OAI-PMH, SWORD), valamint legyenek meg a kapcsolódásai a publikációs ökoszisztéma fontos szereplöinek adatbázisaihoz.

Példaként emlithetjük a konferenciaszervezés terén az EasyChair-t (NWS is), ez egy ingyenes, web alapú szolgáltatás, de nem nyilt szoftverrel. Az OpenConf ingyenes közösségi verzióval rendelkezik, letölthető, de felhő alapon is használható.

13 COUNTER - felhasználási statisztikák szabványositása; https://www.projectcounter.org/

14 Loss of Copies Keep Stuff Safe - https://www.lockss.org/ 
A folyóirat kiadói rendszerek közül a DpubS-ot emlitjük, valamint a Digirati/eLife Libero felhőszolgáltatást (publishing cloud), de számos további rendszer is létezik ${ }^{15}$.

Természetesen egyedileg fejlesztett, nem kifejezetten folyóiratok számára készült és általános nyiltt forráskódú tartalommenedzsment (CMS) rendszereken alapuló folyóirat-honlapokhoz is fejleszthető OAI-PMH és SWORD kapcsolódási lehetőség - de megfontolandó, hogy ehelyett/inkább az elterjedt és jó képességü célszoftvereket alkalmazzuk.

Felhívjuk a hazai indie szakfolyóiratok kiadóit az együttmüködésre. Müködjünk együtt a közös keresö alkalmazásában, az OJS Magyar Felhasználói Csoport müködtetésében, egy esetleges jövőbeli idézettséggyüjtés kialakitásában! 


\title{
Új könyvtári fogalmak gyakorló könyvtárosok szemszögéböl
}

\author{
Hubay Miklós \\ Petöfi Irodalmi Múzeum \\ hubaym@pim.hu \\ ORCID: 0000-0002-3241-2988 \\ Gyuricza Andrea \\ Magyar Tudományos Akadémia Könyvtár és Információs Központ \\ gyuricza.andrea@konyvtar.mta.hu \\ ORCID: 0000-0003-3960-5499
}

As the landscape of libraries changes nowadays, there are more and more new concepts, which are often defined with other, incomprehensible terms in scholarly context. A new trend of library cataloging has appeared, that broke up with the 50-years-old traditions, and besides the simple registering of bibliographic data, it is necessary to put these data in a broader context, in a network. In order to accomplish this task, some of the experimenters use the good old solutions, while others define new theoretical borders. The definitions in the library journals sound very well, while the practice-centered approach is missing.

Now we clear the meaning of some of these library and IT science terms (LRM, discovery, semantic web, MARC21, FRBR, RDA, entity, BIBFRAME, URI, schema.org etc.), so the patron service librarians and also the catalogers can understand the transformation of LIS, can interpret the connections, correlations, and the main goals.

Keywords: library cataloging, entity, MARC21, RDA, BIBFRAME

A könyvtári feldolgozási munkafolyamat lényeges, a hiteles információszolgáltatás szempontjából legfontosabb állomása a bibliográfiai leírások visszakereshetőségét biztositó hozzáférési pontokmegállapítása. Ezekazún. authorityadatokazérvényben lévő szabályozás szerint a személy- és testületi nevek, a földrajzi nevek, valamint a címek; ezeken felül pedig különféle tárgyszavakat, tezauruszokat is használunk. Az integrált könyvtári rendszerekben a legkülönfélébb adatokat tartalmazó authority rekordok emelhetök be a leiró rekordokba, amelyek összességét authority filenak hívják. Napjainkban az authority file már nem csupán az egyes rendszerekben, hanem az intézményeken kívül, azoktól függetlenül is létezhet - átjárást teremtve a gyüjtemények között - az ilyen szolgáltatásokat névtérnek nevezzük.

Ezek az állományok a leggyakrabban ugyancsak személynevekböl (pl. VIAF, Virtual Internet Authority File), ULAN - Union List of Artist Names stb.), földrajzi nevekböl (pl. GeoNames), testületi nevekböl stb. épülnek, de természetesen tárgyi névterek, köznévterek is léteznek (pl. Getty). A személyek, kutatók kétséget kizáró azonositására mindazonáltal több lehetöség is kinálkozik a VIAF mellett. Ilyen például az ISNI (International Standard Name Identifier), vagy az ORCID (Open Researcher and Contributor ID) azonositók. A dokumentumok körében az ISBN- 
azonositás mellett új lehetőség az elektronikus formátumoknál a DOI (Digital Object Identifier) azonosító. Az információ- és webtechnológia fejlődésének köszönhetően napjainkban már magukat a "dolgokat" (kézzelfogható és fogalmi egyaránt) is lehetőségünk van a számítógépes feldolgozás számára egyértelmüen azonosítani, ezek az URI (Universal Resource Identifier) azonosítók.

A könyvtári katalogizálás - amelyet ma forrásleirásként emleget a szakirodalom elméleti alapjait az 1990-es évek végéig a Párizsi Alapelvek, gyakorlati instrukcióit pedig az európai ISBD (International Standard Bibliographic Description), illetve az angol-amerikai AACR2 (Anglo-American Cataloging Rules) szabályzatok adták. A XX. század utolsó éveiben azonban, a megsokasodó dokumentumtípusok és újfajta információhordozók megjelenése szükségessé tette, hogy a szakemberek elgondolkodjanak a bibliográfiai kontrollról és jövőjéről, amelynek egy új, általános elveket tartalmazó dokumentum megszületését köszönhetjük (ICP, International Cataloging Principles). Megvizsgálták azt is, hogy az információkat visszakereső használó mit vár az egyes rekordoktól, melyek azok a lényeges tematikai egységek, amelyekröl tájékozódni szeretne. Ez a használóközpontú, a rekord funkcióit előtérbe helyező elemzés adta az alapját a katalogizálás új, entitásokra épülő elméletének, amelyröl 1997-ben olvashattunk elsöként - ez volt az FRBR (Functional Requirements for Bibliographic Records), késöbb az FRAD (Functional Requirements for Authority Data), majd az FRSAD (for Subject Authority Data). Az IFLA ezeket a különálló modelleket 2017-ben egységes szerkezetbe foglalta, megszüntetve a közöttük lévő következetlenségeket (LRM, Library Reference Model).

A 2010-es években a funkcionális modellekre alapozva új forrásleírási szabályzatot dolgoztak ki, amely eredetileg az AACR harmadik kiadása lett volna, végül azonban RDA (Resource Description and Access) néven látta meg a napvilágot. A gyakorlati megvalósitásra azonban csak mostanában kezdenek hangsúlyt fektetni, mivel az informatika jelenlegi eszközei minden eddiginél hatékonyabb implementációt tesznek lehetővé. A közgyüjtemények legelterjedtebb adatcsere-formátumának, a MARC-nak (Machine-Readable Cataloging) ugyanis egyre több kritikával kell szembenéznie a világháló és az évröl-évre egyre hatékonyabb keresömotorok megjelenése óta. Ez a tény a már több mint fél évszázada alkalmazott technológiák, szabályok átgondolására, megújitására vagy éppen megkérdőjelezésére inditotta a szakembereket. Egyesek a MARC lehetöségeit igyekeznek bőviteni, míg mások a világháló előnyeit kihasználó, teljesen új lehetőségeket biztositó adatformátum implementálásán, valamint a keresőoptimalizálás általános elveinek való minél hatékonyabb megfelelésen gondolkodnak.

Az adatok összekapcsolódásán alapuló szemantikusweb-technológia fö építőkövei közé tartoznak a fent említetteken kívül az egyes tudományterületek összefüggéseinek, relációinak formalizált leírását tartalmazó ún. ontológiák, avagy szótárak. A könyvtártudomány területén is számos ilyet ismerünk - pl. a Kongresszusi Könyvtár által fejlesztett BIBFRAME (Bibliographic Framework) -, és napjainkban is egyre-másra jelennek meg újak, a már meglévők pedig fejlödnek, tökéletesednek. 
A szótárak segitségével, RDF-tripletek (Resource Description Framework) formájában kifejezett adathalmazt azután egy nyilvánosan hozzáférhető tárhelyről (triplestore) bárkinek szolgáltathatjuk, akinek szüksége van rá.

Napjainkban igen eröteljes átalakuláson mennek át azok a felületek is, amelyeken a források feldolgozása, valamint szolgáltatása történik. Úgy hisszük, senkinek nem kell bemutatni a magyarországi piacon jelenlévő integrált könyvtári rendszereket (Aleph, Amicus, Corvina, Huntéka, Szikla, Szirén stb.), vagy a dijmentesen (opensource) hozzáférhető megfelelöiket (pl. a KOHA), és az OPAC (Online Public Access Catalogue) fogalma sem kiván bövebb definíciót. E felületek azonban az utóbbi években természetes evolúción mentek keresztül, amelynek fö mozgatórugója a világhálóba való szervesebb beépülés, valamint az egymástól elkülönülö helyeken létező tudás összegyüjtése, integrálása volt. A letölthető, telepíthető, ún. kliensalapú rendszereket az integrált könyvtári platformok, az OPAC-okat pedig a discoveryszolgáltatások - és az ezek müködését hatékonyabbá tévö SFX (Special Effects) váltják fel fokozatosan.

A könyvtár ma már nem elégedhet meg a hagyományos, nyomtatott formátumú dokumentumok szolgáltatásával: tartalmait elektronikus formában, vagy éppen online is elérhetővé kell tennie a felhasználók számára. A vonatkozó szakirodalom zavarbaejtően sok kifejezéssel illeti a XX-XXI. századi szolgáltatási formákat implementáló gyüjteményeket, amelyek értelmezése akár szerzőnként, munkaközösségenként is eltérő lehet. Annyit azonban biztosan elmondhatunk, hogy napjainkban a digitális-digitalizált gyüjtemények épitésének és kezelésének kiterjedt eszköztára van - repozitóriumok, adatátviteli protokollok, publikációs lehetöségek, illetve az open access-mozgalom -, amely segítséget nyújt a források feldolgozásában, tárolásában, szolgáltatásában, illetve lehetőséget biztosit az elérhető tartalmak egy felületen történő megjelenitésére, az ún. tartalomaggregációra.

Végezetül mindenképpen érdemes szót ejteni arról a nagy informatikai átalakulásimegújulási folyamatról, amely napjainkban is zajlik az Országos Széchényi Könyvtárban. Az OKR (Országos Könyvtári Rendszer) néven ismert projekt számos területen tüzött ki célokat, illetve határozott meg feladatokat, amelyek megvalósítása párhuzamosan, szakmai munkacsoportokon keresztül zajlik. A legfontosabb részterületek az alábbiak:

- új integrált, országos használatra tervezett könyvtári platform bevezetése, mely lehetövé teszi a hazai közgyüjtemények együttmüködését (OKP, Országos Könyvtári Platform);

- a munkafolyamatok szabványosítása, a rendelkezésre álló normativ dokumentumok magyar nyelvre forditása, kiemelt figyelemmel az egységes szakmai terminológiára;

- nagy teljesitményű digitalizáló mühely kialakitása, ahol állományvédelmi és szolgáltatási célú digitalizálás egyaránt történhet;

- az intézmény általános informatikai infrastruktúrájának fejlesztése;

- kiemelt tartalomfejlesztési részterület, amelynek keretén belül olyan 
szolgáltatások valósulnak meg, mint az egy-egy szükebb témát feldolgozó Tudástárak, vagy a könyvtári feldolgozó munkát és az internethasználók általános tájékozódását jelentősen támogató Magyar Nemzeti Névtér. ${ }^{1}$

A projektben a fentiek mellett nagy figyelmet forditanak a magyar vonatkozású webhelyek archiválására és egy internet-archívum kialakitására is.

Az alábbiakban közöljük a fentebb emlitett témákhoz kapcsolódó legfontosabb fogalmak bővebb, részletesebb magyarázatát.

BIBFRAME: Könyvtártudományi ontológia, avagy szótár, amely a forrásleirások készitéséhez szükséges legfontosabb relációkat, viszonyokat tartalmazza. Készitöi szerint ez a szótár lehet a jövöben a MARC helyett a könyvtárak egységes adatcsereformátuma.

COMPASS: A Magyar Tudományos Akadémia könyvtára által gondozott, országos szintü adatbázis, amely a magyar könyvtárakban elektronikus formában elérhetö, kurrens és archiv tudományos adatbázisok listáját tartalmazza.

Discovery: Az online könyvtári források (a helyi nyomtatott állomány online katalógusa, helyi és kereskedelmi adatbázisok stb.) egyetlen felületen való kereshetövé tétele egyetlen keresömező alkalmazásával (vö. Google) A legismertebb discoveryszolgáltatások a Primo, a Summon vagy az EBSCO Discovery Service (EDS), a nyilt hozzáférésü megoldások közül pedig a VuFinddal, valamint a Blacklighttal találkozhatunk a legtöbb közgyüjteménynél.

DOI (Digital Object Identifier): Az online dokumentumok körében használt egyedi azonositó rendszer, biztositja a dokumentumok megtalálását is.

FRBR, FRAD, FRSAD: A bibliográfiai, besorolási és tárgyi besorolási rekordok funkcionális követelményeit tárgyaló elméleti modellek. Tartalmazzák a rekordok használói szempontból lényeges egységeinek (entitások) leírását és ezen egységek közötti kapcsolatokat.

ICP (International Cataloguing Principles): A 2016-ban kiadott alapelv-nyilatkozat felváltotta és határozottan kibövitette a "Párizsi alapelvek" alkalmazási területét a csupán szöveges forrásoktól az információforrások valamennyi típusáig. ${ }^{2}$

ISNI (International Standard Name Identifier): Nemzetközi szabványos névazonositó. Személyek minden kétséget kizáró azonositására szolgál, rendszerint négyszer négy számjegyböl áll.

OKR-projekt lelektronikus dok.] http://www.oszk.hu/Okr-projekt [letöltés: 2019.07.18.] Nyilatkozat a Nemzetközi katalogizálási alapelvekröl lelektronikus dok.] URL:

http://www.oszk.hu/sites/default/files/ICP_2016_magyarul_blogra_modositott.pdf Iletöltés: 2019.07.18.] 
Linked data: Az adatok hálózatba szervezésének, összekapcsolásának technológiája. Nem csupán a két kapcsolódó elem, de a köztük lévö viszony leirását is elvégezhetjük a segitségével. Informatikai alapkövei az egységes forrásazonositó (URI), illetve a formalizálást lehetővé tevő forrásleiró keretrendszer (RDF).

LRM (Library Reference Model): Az IFLA által kidolgozott, egységes fogalmi modell, mely összesen 11 entitást határozott meg, amelyekröl a forrásleirás során "beszélni" lehet (Res, Mü, Kifejezési forma, Megjelenési forma, Példány, Ágens, Személy, Kollektiv ágens, Nomen, Hely, Idötartomány). ${ }^{3}$ Az LRM megjelenése szükségessé tette az RDA alapos átdolgozását.

MARC21: Az1998-1999-ben közzétett MARC21 a MARClegfrissebb, ma is folyamatosan aktualizált változata, a 21-es szám a XXI. századra utal. Legutóbbi módositásai figyelembe veszik az új dokumentumtipusok sajátosságait, és már az RDA-ban definiált új adatelemek leirhatóságát, valamint a korszerübb formátumokra történö konverziót is szolgálják.

Névtér: Besorolási (authority) adatokállománya, az intézményekben végzettforrásleiró munkától többnyire függetlenül épül.

Nyilt forráskód (open source): Olyan szoftver, mely a forráskód elérhetösége révén a tetszöleges célú futtatás, a testreszabás, továbbfejlesztés, tökéletesités jogát biztositja a felhasználóknak. A nyilt forráskódú szoftvereken fejlesztéseket végzök egymást segitö közösségekben tevékenykednek.

OAl-PMH (Open Archives Initiative - Protocol for Metadata Harvesting): A Dublin Core formátumra épitő, metaadat-begyüjtő protokoll, melynek segitségével különféle gyüjteményeket lehet egyszerü utasitások segitségével lekérdezni, vagy köztük adatcserét megvalósitani.

OJS (Open Journal Systems): Nyilt forráskódú, ingyenesen letölthetö és használható, tudományos folyóiratok online közzétételére kifejlesztett folyóirat-menedzselö és publikáló rendszer.

Open Access: A tudományos közlemények nyilt hozzáférésü publikálása, mely a felhasználó számára biztositja az olvasás és esetlegesen a további felhasználás legális, financiális, szervezeti vagy technikai megkötések nélküli lehetöségét. ${ }^{4}$

ORCID (Open Research and Contributor Identifier): Nemzetközileg elfogadott szerzőazonositó kód, mely biztositja a kutató egyértelmü azonositását. Segitségével visszakereshetö az adott kutató tudományos munkássága. Az ISNI részhalmaza.

\footnotetext{
3 IFLA könyvtári referenciamodell : A bibliográfiai információk elméleti modellje lelektronikus dok.] https://www.ifla.org/files/assets/cataloguing/frbr-Lrm/ifla-Lrm-august-2017_rev201712-hu.pdf [letöltés: 2019.07.18.]

4 Open Access lelektronikus dok.] URL: nkfih.gov.hu/download.php?doclD=29473 [letöltés: 2019.07.18.]
} 
Platform: a hagyományos integrált könyvtári rendszerek funkcióit kináló, böngészö segitségével elérhetö felület. Az új környezet egyszerübbé teszi más, külsö adatforrások felhasználását pl. a forrásfeldolgozásban, igy megszünteti az információk elszigeteltségét. A könyvtári platformokhoz discovery-szolgáltatások kapcsolódhatnak. Könyvtári platform pl. az Alma, az OLlsuite, valamint a közösségi fejlesztésü FOLIO.

RDA (Resource Description and Access): Forrásleirás és hozzáférés. Katalogizálási szabályzat, az AACR harmadik, jelentösen átdolgozott változata. A források leirásának alapjává az entitásokat és azok kapcsolatait tette, a leirás során a feldolgozó könyvtáros az RDA fejezeteit követve gyakorlatilag entitásokat ir le egymás után.

RDF (Resource Description Framework): Forrásleiró keretrendszer, amely lehetövé teszi, hogy a számitógép számára értelmezhető módon (formalizáltan) irjunk le két elemet, valamint a köztük lévö kapcsolatot. Az RDF igy tehát három elemböl álló "mondatokat", állitásokat kezel, amelyeket tripletnek hívunk.

Repozitórium: Egyetemekenéskutatásiintézményekbenmüködö dokumentumszerver, amely tudományos anyagok archiválására és világszerte nyilt hozzáférhetövé tételére szolgál.

schema.org: A Google, a Microsoft, a Yahoo, valamint a Yandex által létrehozott kezdeményezés - egy újabb szótár -, amely segít a könyvtári rekordokat a Google-ba juttatni.

SFX: A kontextusérzékeny referenszlinkelés platformfüggetlen eszköze, amely könyvtári forrásokhoz dinamikusan generált linkhalmazokat hoz létre, s teszi mindezt az elektronikus dokumentum metaadataira támaszkodva. ${ }^{5}$

SPARQL: Az RDF-adatbázisok lekérdezönyelve, adat-átalakitásra is alkalmas (pl. egyik szótárról a másikra, pl. BF-schema.org)

Szemantikus web: Más néven web 3.0. A napjainkban ismert világháló egy olyan új rétege, amelyben az egyes elemek, adatok között a számitógépes feldolgozás számára is jelentéssel, értelemmel biró, azaz informatikai eszközökkel tipizált, minösitett kapcsolatok állnak fenn.

Triplestore: Adatbázis-kezelö rendszer, amely a relációs adatbázisokkal ellentétben az adatokat nem adattáblákban, hanem tripletekben tárolja (gráf-adatbázis). Ezen adatbázis lekérdezö felületét (ún. SPARQL-endpoint) nyilvánosan hozzáférhetövé lehet tenni.

5 BÁNHEGYI Zsolt: Cummings, Joel-Johnson, Ryan: Az SFX használata és használhatósága = Tudományos és Müszaki Tájékoztatás, 51. évf. (2004) 1. sz., p. $42-44$ 
URI (Universal Resource Identifier): Univerzális azonositó. A világon mindennek adható, legyen az kézzelfoghatóan vagy fogalmi szinten létezö dolog. Ha a dolgokat és viszonyaikat egyaránt URI-kkal azonositjuk, a számitógépes feldolgozás számára nem csupán a létezöket, de a köztük lévö kapcsolatot is formalizálni tudjuk.

VIAF (Virtual Internet Authority File): Virtuális, internetes besorolási állomány, több könyvtár (leginkább nemzeti könyvtárak) besorolási (authority) állományaiból épitették. Alkalmas a személyek egyértelmü azonositására.

Webarchiválás: weboldalakvagywebhelyekvalamilyen rendszeresvagyrendszertelen idöközönként megismételt mentései. A webarchivumok keresörobotjai a linkeket követve keresik fel és mentik a weboldalakat, valamint egyéb fájlokat, amelyeket visszakereshetöen tárolnak. A legismertebb webarchivum az Internet Archive. ${ }^{6}$

6 DRÓTOS László-KOKAS Károly - Webarchiválás és a történeti kutatások = Digitális 


\title{
Parazita folyóiratok, a tudományos világ élösködői
}

\author{
Juhász Attila \\ Debreceni Egyetem, Informatikai Tudományok Doktori Iskola \\ juhaszattila93@gmail.com \\ Szabó Dóra \\ Debreceni Egyetem, Informatikai Kar, Könyvtártudományi Tanszék \\ szabog6dora@gmail.com
}

The emergence of open access undoubtedly had a positive impact on the efficiency of scientific communication. Among other things it eliminated the spatial and temporal constraints, improved international cooperation, and caused the shortening of research times. However, parallel to this, predatory publications, that pose a threat to the scientific world due to their profit oriented pseudo-scientific activity, also appeared. Our paper discusses ongoing research that examines the scientific visibility of educators in domestic institutions of higher education and their relation to predatory journals.

Keywords: Open Access, predatory journals, scientific visibility

\section{Bevezetés}

Az Open Access (OA), azaz a nyilt hozzáférés megjelenésével a tudományos tartalmak digitális formában, online elérhetővé váltak. Ezen publikációk jogi korlátozás nélkül, a megfelelö hivatkozásokkal szabadon felhasználhatóak mindenki számára. Ebböl következett, hogy felgyorsult a tudományos kommunikáció sebessége, hiszen a legfrissebb kutatási eredmények bárhol, bárki számára elérhetővé váltak, ezáltal sikerült áthidalni a korábbi tér-és idöbeli nehézségeket, ami előnyös lehet a nemzetközi kutatások hatékony összehangolása esetében is. Az elektronikus megjelenésnek köszönhetően nőtt a szerzök olvasottsága, mely a legtöbb esetben megmutatkozott az idézettségükön is. Ugyanakkor a pozitiv hozományok mellett a negativumokról sem feledkezhetünk meg. Megjelentek az úgynevezett ragadozó kiadványok, melyek magukat tudományos kiadványként tüntetik fel, viszont valójában profitorientált, a tudományosságot nélkülöző lapokról van szó. A jelenlétük azért is ártalmas, mert általuk számtalan áltudományos mü válik elérhetővé bárki számára, ezáltal csorbítva a tudományosságba vetett hitet. Alább a jelenleg folyamatban lévő kutatásunkat ${ }^{1}$ ismertetjük, amelyben a hazai egyetemek oktatóinak tudományos láthatóságával és a ragadozó kiadványokhoz füzödö viszonyával foglalkozunk.

\footnotetext{
1 https://docs.google.com/forms/d/19gJpNv-Hk2JP-iVh4YBqolcbzdhcracV204dhuPPibo/ edit? Usp=forms_home (2019. 06.30.)
} 


\section{A ragadozó folyóiratok}

A parazita, vagy más néven ragadozó folyóiratok ${ }^{2}$ (angolul predatory journals) a tudományos világ élősködőiként jelentek meg az elektronikus publikációk térhóditásával. A ragadozó kiadványok tudományos folyóiratokálcáját öltik magukra, nivós lapként tüntetik fel magukat, viszont nem válogatják meg a publikálandó cikkek körét, a megfelelő dijak fejében bármit közzétesznek. A szerkesztőbizottság tagjait az interneten toborozzák, a kutatókat pedig kéretlen levelekkel bombázzák, hogy náluk tegyék közzé legújabb eredményeiket. A megtévesztés módszerét alkalmazzák: nivós lapokhoz hasonló nevet és megjelenést választanak. Mivel nem ellenörzik a cikkeket, nem felelnek meg a tudományos folyóirat-kiadás szakmai követelményeinek. Tevékenységüksúlyoskárokatokoz, mivelcsorbítjaatudományos világba vetett hitet. Ez azért is jelentős probléma, mert a nyilt hozzáférés korában már bárki hozzáférhet ezen ellenörizetlen cikkekhez, amelyek, megtéveszthetik azon olvasókat, akik hiteles információhoz szeretnének hozzájutni. Tevékenységük egyik táptalaja a napjainkban jól ismert publish or perish elv ${ }^{3}$ miszerint a tudományos elömenetelhez nélkülözhetetlenné vált a megfelelő számú publikáció megléte, azaz létrejött a publikálási kényszer. Az említett elv szerint, aki nem publikál az nem juthat elöre a tudományos ranglétrán. A ragadozó folyóiratok természetesen erre sem kínálnak igazi megoldást, hiszen, ha egy kiadóról kiderül, hogy parazita tevékenységet folytat, abban az esetben a szerzők ott megjelentetett cikkeit nem fogadják el a tudományos elörehaladásukhoz, illetve a pályázataikhoz. A ragadozó tevékenység először Jeffrey Beall ${ }^{4}$ amerikai könyvtárosnak szúrt szemet, aki el is készitette 2011-ben az általa parazitának vélt kiadványok listáját (Beall-lista) ${ }^{5}$, illetve folyamatosan frissitette azt. A munkáját 2017-ben kénytelen volt befejezni az öt ért folyamatos támadások miatt, a lista pedig elavulttá vált, hiszen az ilyen jellegü kiadványok száma egyre csak nő. Ezért is fontos a megfelelö körültekintés, mielött a szerzők kiadnák kézirataikat a kezükböl. Ehhez szükség van a ragadozó lapok ismérveinek alapos ismeretére, valamint érdemes a DOAJ-ban ${ }^{6}$ is megnézni, hogy szerepel-eottazadottkiadvány, hiszen ottmegtalálhatóakazindexeltOAkiadványok.

\section{A kutatók és a tudományos láthatóságuk vizsgálata}

Mint a fentebb emlitett publish or perish elvből kiderült, a megfelelő számú publikáció elengedhetetlen ahhoz, hogy a kutató elöre juthasson a szakmai ranglétrán. Ajelenleg is folyó, terveink szerint reprezentativ mintát elérő elektronikus felmérésünkben (elektronikus Google kérdőiv), melyre jelenleg 500 válaszadónk van, arra keressük a választ, hogy mi motiválja a hazai felsőoktatásban az oktatókat.

\footnotetext{
$2 \quad$ Holl András, Parazita folyóiratok (predatory journals), URL: https://www.mtmt.hu/system/files/parazita_folvoiratok.pdf (2019. 06. 30.)

3 Erzsebet, Dani: How "Publish or Perish" Can Become "Publish and Perish" in the Age of Objective Assessment of Scientific Quality URL: http://www.iiisci.org/journal/CV\$/sci/pdfs/IP052LL18.pdf (2019. 06. 30.)

4 Interjú Jeffrey Beallel, Könyv, Könyvtár, Könyvtáros, URL: http://ki2.oszk.hu/3k/2016/09/atudomany-eloskodoi-denveri-beszelgetes-jeffrey-beall-lel//2019. 07. 21.)

$5 \quad$ Alan Burdick: "Paging Dr. Fraud": The Fake Publishers That Are Ruining Science, The New Yorker 5 BEALL'S LIST OF PREDATORY JOURNALS AND PUBLISHERS URL: https://beallslist.weebly.com/ (2019. 03. 11.)

6 Directory of Open Access Journals https://doaj.org/ (2019. 06. 30.)
} 
Ez a kérdés azért releváns, mert aki motivált az elörejutás felé, az feltehetően szeretné, ha a tudományos munkája szélesebb körben lenne elérhetö, hiszen így növelhető az idézettsége, amire az OA folyóiratok tökéletes lehetöséget nyújtanak. Feltehetően a motivált válaszadók a saját intézményük repozitóriumán túl egyéb felületeken is közzéteszik a munkáikat (pld. Google Scholar, Research Gate, esetleg személyes honlap). Hazánkban az elektronikus közzététel egyik legismertebb felületea Magyar Tudományos Müvek Tára (MTMT)7 , amely nem repozitórium, hanem nemzeti bibliográfiai adatbázis, melynek müködése törvény által is szabályozott. A kutatásunk során azt is megvizsgáljuk, hogy a megkérdezettek mekkora része gondozza rendszeresen ezen felületét. Ez azért is fontos, mert itt a szerzőknek lehetöségük van arra, hogy könnyedén összeállithassanak bibliográfiákat, publikációs listákat, amelyeket felhasználhatnak pályázatok során is, mely szintén összefüggésben állhat a motiváció mértékével. Továbbá vizsgáljuk azt is, hogy a megkérdezettek mekkora része publikált már nyilt hozzáférésü folyóiratban, illetve, ha esetleg még nem, akkor nyitott-e ezen megjelentetési forma irányába, vagy inkább tartózkodnak töle. A felmérés egyik legfontosabb kérdése pedig azokhoz szól, akik már publikáltak nyilt hozzáférésü kiadványban, esetükben ugyanis azt szeretnénk megtudni, hogy tapasztalták-ea tudományos láthatóságuk növekedését a nyilt hozzáférésnek köszönhetöen. A nemzetközi tapasztalat szerint egyértelmüen megállapitható, hogy nö azon kutatók idézettsége ${ }^{8}$, akik szabadon elérhetővé teszik eredményeiket. Úgy véljük, hogy ez a hazai válaszadók esetében sem lesz másként.

Továbbá szeretnénk megtudni, hogy a szerzők rendelkeznek-e ORCIDª azonositóval. Ennek az a lényege, hogy a szerzők egyértelmüen azonosithatók legyenek, mivel gyakoriak a névazonosságok, amelyek problémát okozhatnak a teljesitménymérés folyamatában. Az utóbbi időben több kiadó is ehhez a dijmentesen létrehozható azonosítóhoz köti a kéziratok befogadását.

\section{A kutatók és a ragadozó folyóiratok kapcsolatának vizsgálata}

A tudományos láthatóságra vonatkozó kérdéseket követően a felmérés túlnyomó részében a hazai felsőoktatási dolgozók és a ragadozó folyóiratok közötti kapcsolatot vizsgáljuk.

Elöször azt szeretnénk megtudni, hogy a megkérdezettek mekkora része találkozott már a tudományos munkája során ilyen jellegü kiadványokkal, vagyis a válaszadók mekkora részét keresték meg valamilyen módon. Úgy véljük, hogy a többség már kapott felkérést ragadozó kiadványoktól valamilyen formában. Ugyanakkor fontos, hogy a szerző el tudja dönteni az adott kiadványról, hogy az valóban parazita tevékenységet folytat-e, melyhez szükség van a megfelelö kritikai érzéken túl arra is, hogy a kutatók ismerjék ezen kiadványok ismérveit. Ennek megismerésére a kitöltés során egy listából kell kiválasztania a lehetséges ismérveket a megkérdezetteknek. Előzetes hipotéziseink szerint a válaszadók nagy többsége képes felismerni az árulkodó jeleket, azaz képes

\footnotetext{
7 Magyar Tudományos müvek Tára, URL: https://www.mtmt.hu/ (2019. 06. 30.)

8 Gemma Hersh, Andrew Plume: Citation metrics and open access: what do we know? URL: https://www.elsevier.com/connect/citation-metrics-and-open-access-what-do-we-know (2019. 03. 11.) 
döntést hozni egy-egy kiadvány jellegéröl. A kérdőív további szakaszában Likert-skála segitségével kivánjuk megismerni a válaszadók véleményét.

A ragadozó folyóiratokra vonatkozó kérdések sorában az első arra vonatkozik, hogy a válaszadó mennyire tartja veszélyesnek a kiadványokat a tudományos világra tekintve. Úgy véljük, hogy a megkérdezettek többsége valós veszélyként tekint ezekre a kiadványokra, hiszen súlyosan csorbítják a tudományba vetett hitet, illetve azontúl, hogy gyakran valótlan információkat közölnek, akár érdemtelen elönyhöz is juttathatják azokat, akik ilyen jellegü kiadványokban publikálnak a tisztességes utat választó szerzőkhöz képest. Aki nem szeretne ezen kiadványok csapdájába esni, fontos, hogy alaposan járjon utánuk. Erre vonatkozik a következö kérdés, miszerint alaposan utánajár-e a szerző az egyes kiadványoknak, mielött ott megjelentetné cikkeit. Szeretnénk azt is megtudni, hogy a válaszadók hogyan vélekednek, arról, hogy társaik képesek-e eldönteni egy-egy folyóiratról, hogy az áltudományos tevékenységet végez-e. Úgy gondolom, hogy a válaszadók többsége már kapott felkérést ilyen kiadványoktól, illetve mint fentebb az ismérvek kiválasztásánál is részleteztük, feltehetően el tudják dönteni, hogy tisztességes OA folyóirattal van-e dolguk.

A ragadozó folyóiratok veszélyt jelentenek áltudományos tevékenységükkel a tudományos világra, viszont szeretnénk megtudni, hogy a válaszadók tulajdonitanak-e nekik esetleg valamiféle elönyt. Ezen elöny lehet akár az is, hogy gyors a publikációs folyamat, hiszen itt nincs valós szakmai bírálat, ebböl adódik az is, hogy hamar kerülnek publikálásra a cikkek. Természetesen ez nem tekinthető a szó szoros értelmében vett elönynek, hiszen ez éppen a minőség rovására megy. Ebböl a kérdésből kiindulva arra is keressük a választ, hogy a megkérdezettek szerint egyes kutatók a személyes elörehaladásuk érdekében akár önszántukból is publikálnának-e ragadozó folyóiratokban. Ezt mindenképpen elítélendőnek tartjuk, viszont mint lehetőséget nem lehet kizárni, hiszen a valós eredmények hiányában elegendő a megfelelő közzétételi dij megfizetése és a kutató máris több nemzetközi cikkel rendelkezhet, amelyet feltüntethet pályázatok benyújtása során, vagy a tudományos elömenetelét biztosithatja a segitségükkel. Viszont, mint korábban írtuk, amennyiben egy folyóiratról kiderül, hogy ragadozó tevékenységet folytat, abban az esetben az ott megjelentetett kiadványokat nem lehet elszámolni semmilyen formában sem, illetve szükséges lenne, ezen tartalmak eltávolitása az elektronikus felületekröl. ${ }^{10}$ Amennyiben egy szerző ilyen jellegü kiadvánnyal találkozik, abban az esetben azt jelentheti az MTMT felé is. ${ }^{11}$

Továbbá vizsgáljuk, hogy a kutatók kellöen tájékozottak-e a ragadozó lapokban történő publikálás veszélyeiről. Ezek nem csupán a tudományos világ hitelességére jelentenek veszélyt, hanem magukra a szerzőkre is, mivel az itt megjelentetett

10 The gth International Conference on Society and Information Technologies: Proceedings Konferencia helye, ideje: Orlando (FL), Amerikai Egyesült Államok, 2018.03.13-2018.03.16. Winter Garden (FL): International Institute of Informatics and Systemics (IIIS), 2018. 43-44p. (ISBN:9781941763742) Jeffrey, Beall: Predatory journals: ban predators from the scientific record, Nature, 534 (2016), 326p. 
munkák nem közölhetőek újra valódi tudományos lapban, tulajdonképpen a semmire fizetnek publikálási költséget, valamint ezen kiadók megtartják a szerzői jogokat is. ${ }^{12} \mathrm{~A}$ parazita folyóiratokban a publikálókat két csoportra lehet bontani. Az egyik, lényegesen nagyobb részük gyanútlan áldozat, akik nem szándékosan publikálnak a kiadványokban, míg a másik, kisebbik részük tisztában van a kiadó tevékenységével. Mindkét csoport tagjaira érvényesek viszont a fentebb ismertetett hátrányok, így érdemes alaposan utánajárni a kiadványoknak.

Ahhoz, hogy a káros tevékenységet folytató kiadók kiszoruljanak a tudományos világ piacáról, véleményem szerint egységes fellépés kellene. A válaszadók véleményét is szeretnénk megismerni a kérdést illetően, és arra számitunk, hogy a többség szintén egyetért az összehangolt fellépés szükségességét illetően. A kérdőív végén arra vagyunk kiváncsiak, hogy az oktatók mit tartanak a nyilt hozzáférés elönyeinek, illetve hátrányainak. Azt gondolom, hogy a válaszadók az ingyenességet fogják a legnagyobb mértékben kiemelni, míg hátrányként a minöségi fenntartások túlsúlyba kerülésére számítok, ami összefüggésben állhat kutatásom tárgyával, a ragadozó folyóiratok egyre növekvő térnyerésével.

A kutatás tavasz végi lezárása után, a kapott válaszok kielemzését követően fogunk tudni pontos képet adni a tanulmányban felmerülö kérdésekre, melyek azt gondolom, hogy igencsak aktuálisak és a tudományos világ összes résztvevőjét érintik valamilyen módon.

\section{4. Összegzés}

Ajelenleg is zajló, reményeink szerint a reprezentatív mintát elérö kutatást két részre oszthatjuk, az első fele a kutatók tudományos láthatóságát vizsgálja, miszerint mennyire motiváltak, illetve amennyiben fontosnak érzik, hogy szélesebb körbe juttathassák el eredményeiket, abban az esetben mit tesznek érte. Illetve szeretnénk megtudni, hogy akik már eddig is jelentettek meg nyilt hozzáférésü cikkeket, ők tapasztalták-e a tudományos láthatóságuk növekedését. A felmérés második, nagyobb része a ragadozó folyóiratokkal foglalkozik. Arról szeretnénk átfogó képet kapni, hogy a válaszadók mekkora része találkozott már ilyen jellegü kiadvánnyal, illetve képesek-e eldönteni egy esetleges megkeresés esetén azt, hogy az adott kiadvány valóban OA jellegü, vagy csupán áltudományos tevékenységet folytat. A Likert-skálás mérések lehetőséget adnak arra, hogy alaposabban megismerhessük a kitöltök véleményét a kérdéskörben, illetve átfogó képet adhassunk a hazai helyzetről. A kutatás lezárása 2019 őszén várható, ezt követően kezdődhet el a kapott eredmények kiértékelése.

\section{Köszönetnyilvánítás:}

A kutatást az "Integrált kutatói utánpótlás-képzési program az informatika és számítástudomány diszciplináris területein" (EFOP-3.6.3-VEKOP-16-2017-00002) címü projekt támogatta. A projekt az Európai Unió támogatásával, az Európai Szociális Alap társfinanszírozásával valósult meg.

12 Farkas Boglárka: Open Access források, a publikálás veszélyei, parazita folyóiratok URL: https://slideplayer.hu/slide/11936495/ (2019. 03. 11.) 


\title{
Egészségügyi informatikai adatbázisban való szöveges keresés mesterséges intelligenciával támogatott szemantikus keresővel
}

\author{
Kovács Béla Lóránt \\ Neumann Technology Kft. \\ bela.lorant.kovacs@negentropics.com
}

\begin{abstract}
Text search in a health database with a semantic search engine supported by artificial intelligence My purpose is to present a search engine which can process large documents- even books- in the query and search in the medical database based on them. The process works without metadata, so it is enough to upload the search text to the database once, the application executes all the rest of the operations. Searching methods are supported by algorithms based on semantical modeling of natural languages, working in any language. Namely, the algorithm learns languages from the databases. However, the search engine is not only capable of conducting semantic searches but define topics by texts that can be monitored automatically by the program. This process is supported by an artificial intelligence what is suitable for determining semantical groups in one hand, on the other hand, it is learning from the database expansion and user behavior - based on which it can improve the hits, - at the same time, it does not collect any data about the user himself, thus complying with the strictest European data protection rules. I intend to present my description through practical examples demonstrating the innovations that make it unique. At the end, I would like to show in detail what measurable performance the software has and how it differs from other search engines.
\end{abstract}

Keywords: semantic search, semantic classification, artificial intelligence, search in text documents

A Neumann Technology Kft. a Gazdaságfejlesztési és Innovációs Operativ Program keretén belül, az Európai Regionális Fejlesztési Alapból és hazai központi költségvetési előirányzatból támogatott GINOP-2.1.7-15-2016-00069 azonositó számú projektben egy unikális szoftver prototipusán kezdett dolgozni. A pályázat eredményeként olyan programot fejlesztettünk, amely webes felületen elérhető és általa a felhasználó képes orvosi szövegekben keresni úgy, hogy az eddig rendelkezésre álló keresőknél pontosabb találatot kapjon. ${ }^{1} \mathrm{~A}$ termék a következő elemekből áll:

- Elöfeldolgozó

- Index adatbázis

- Kereső adatbázis

- Kereső modul

1 Méréseinket 2019 márciusában végeztük. Ennek során kifejezetten az orvosi cikkeket tartalmazó adatbázisok és a hozzájuk kapcsolódó keresők vizsgálatára koncentráltunk. az olyan vizsgálatoktól, amely webes keresők pontosságát is mérte volna, mint amilyen Bennett Shenkeré, tartózkodtunk. (v. Ö.: [1]) 
- Végfelhasználók által elérhető kereső funkciókhoz kialakitott felület

- Karbantartó munkatársak által használható funkciókhoz kialakított felület

- Vezetö munkatársak által használható funkciókhoz kialakitott felület

A keresömotor, amelyet az Aleetheia névre kereszteltünk, két szempontból is figyelemre méltó: egyrészt a természetes nyelvek szemantikájának modellezését és a mesterséges intelligencia alkalmazását a korábbiaktól eltérő módon oldja meg. másrészt a korábbi, hasonló keresőkhöz képest pontosabb és teljesebb találati listát ad. Éppen ezért a továbbiakban a program rövid bemutatása után ez utóbbi tulajdonságára összpontosítok a terméknek - minthogy a felhasználók számára is ez a legfontosabb² - és azt kivánom bemutatni, hogy mit értünk az alatt, hogy pontosabb és teljesebb találati listája, mint a más szoftvereké.

\section{A program müködése}

A felhasználóka publikus interfész rétegen keresztülkapcsolódhatnaka szolgáltatási réteghez, amelynek a segitségével az alkalmazás funkciókat érhetik el, például a tartalom szerinti keresést. A szolgáltatási rétegben a vezérléseket megfelelő szolgáltatási csatornán fogadjuk, azokat értelmezzük és ütemezetten végrehajtjuk. A szolgáltatási réteg képes fogadni a parancssori és a webes szolgáltatási kéréseket, és az elemző ezeket ütemezetten fogadva és végrehajtva kapja meg. Az alkalmazás magjával készitjük a dokumentum elöfeldolgozását. Különböző formátumú szöveges dokumentumok konvertálása, a konvertált tartalmak átadását végzi az elemző részére. Az elöfeldolgozó képes a különböző dokumentum formátumok konvertálására. Elvégezzük a tárolást, mely modul feladata kettős: egyrészröl tárolni az előfeldolgozó által átalakitandó bemeneti forrásokat, illetve az elemző által kategorizált kimeneti adatokat, döntésekhez szükséges információkat. Tárolja a tanuló adatbázist, a számitott eredményeket, illetve megfelelő formátumra konvertált dokumentumokat. Ezt követöen elemzéseket végzünk, az elöfeldolgozott forrásokon a kategorizáláshoz szükséges döntéseket hozó algoritmusok végrehajtásával (tanulás, osztályozás, döntés, klaszterezés), illetve a feldolgozott források meghatározott struktúrában való elhelyezésével. Másrészt az emlitetteken kivül az instrukciók nélküli, tartalom alapján végzett csoportképzéshez szükséges algoritmusokat is tartalmazza és futtatja.

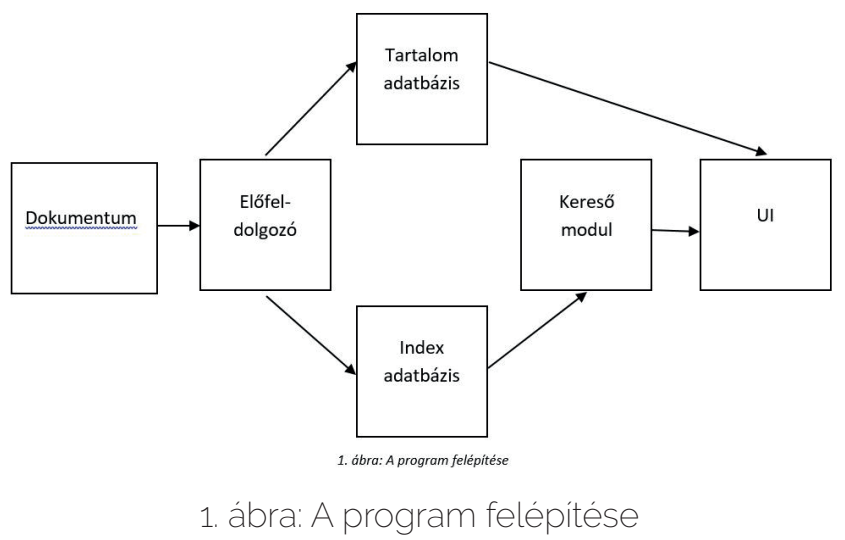

2 A felhasználók érdeklődéséről: a találatok pontosságáról és teljességéröl bővebben lásd.: [2] 


\section{A program pontossága}

A pontosságot úgy mértük, hogy kutató orvosokat és doktoranduszokat kértünk meg arra, hogy a PubMed adatbázisán egy-egy keresés kapcsán osztályozzák a találatok pontosságát. ${ }^{3} \mathrm{~A}$ találatokat egytöl tízig pontozták úgy, hogy a tízes találat ért a legtöbbet, az egyes pedig a legkevesebbet, és minden keresésnél a találati lista első húsz elemét vizsgálták meg. A saját találatainkat két keresési algoritmussal adtuk meg: az első kulcsszavak, a második teljes szövegekkel történő keresésre alkalmas. Ezeket a találatokat vetettük össze a PubMed saját keresöjével, amely ugyan alapvetöen kulcsszavas, de metaadatokat is figyelembe vesz. ${ }^{4} \mathrm{~A}$ mi algoritmusaink nem vettek figyelembe metaadatokat és a mérés során nem használtunk keresésre olyan hosszúságú szövegeket, amelyek a PubMed keresöjén nem futnak le. Arra is figyeltünk, hogy ne hibridizáljuk a különbözö algoritmusaink által kinált eredményeket, mert ugyan ezáltal még nagyobb pontosságra tehettünk volna szert, ugyanakkor elfedtük volna az egyes algoritmusok valódi képességeit. A továbbiakban éppen ezért a PubMed 19 millió dokumentumot tartalmazó adatbázisán lefuttatott keresések kapcsán három találati listát hasonlitunk össze: a saját kulcsszavas, a saját teljes szöveges algoritmusaink, illetve a Pubmed keresöje által adottakat. A kereső felület a következő módon néz ki:

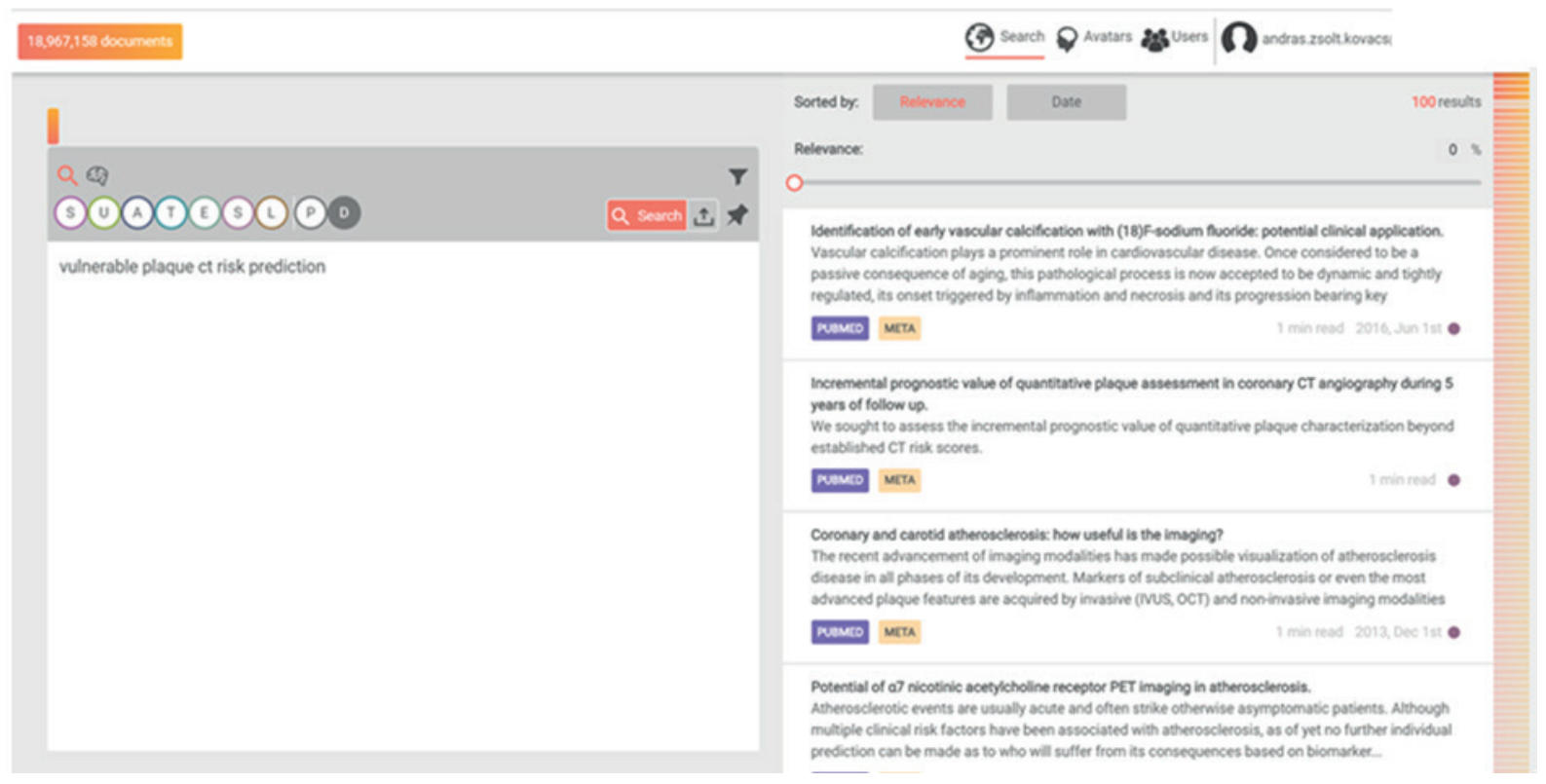

2. ábra Kereső felület (Jobb oldalon a találati lista, bal oldalon a kereső ablak az algoritmusválasztóval)

A felületen látható az algoritmusválasztó, amely a termék végleges változatában nem lesz a felületre kivezetve, mivel a választást az emberek helyet hibridizációs algoritmusok végzik. Számos további funkcióval rendelkezik a program, amelyeket

\footnotetext{
3 A méréseket 2019. januárja és márciusa között végeztük négy orvos és két doktorandusz bevonásával.

4 A hagyományos kulcsszavas keresök esetében - amilyenek például az egészségügyi adatbázisokban vagy a vállalti adatbázisok keresőiben müködnek - kétféle eljárást szoktak kombinálni: az első a keresett kulcsszó gyakoriságából, a második a hozzá kapcsolódó metaadatok (tárgyszavak, tag-ek) előfordulásából szokott kiindulni. ( v. ö.: [4].)
} 
azonban hely hiányában nem tudunk bemutatni (témákhoz tartozó szófelhök és szóstatisztikák, trendek, szerzőkre vonatkozó statisztikák stb.).

\section{Első mérés}

A keresöbe írt kifejezés a következö volt: „vulnerable plaque ct risk prediction”.

Az Aleetheia kulcsszavas algoritmusa 75\%-os pontosságot ért el, a szöveges azonban csak 57\%-ot. A hagyományos kereső 72\%-os pontosságra volt képes.

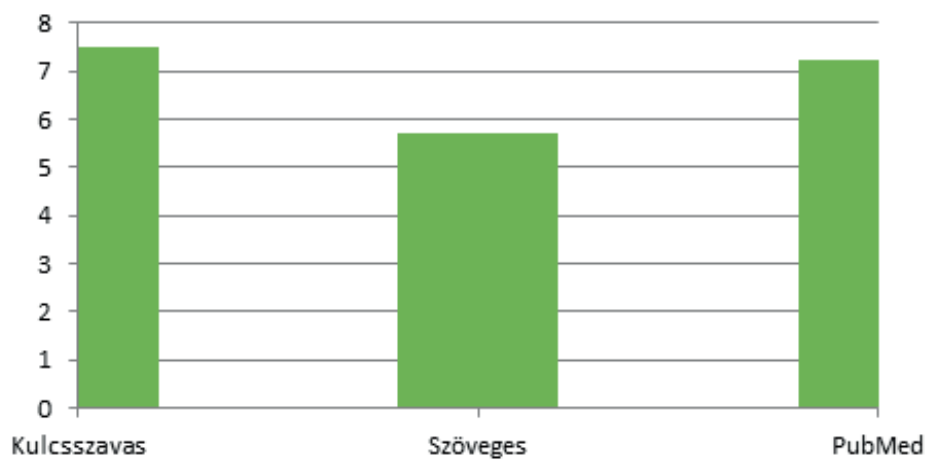

1. Az elsö keresés pontossága

A találatok részletes elemzéséböl kiderül, hogy a kulcsszavas kereső annak ellenére adott pontosabb találatokat, hogy nem használt metaadatokat. Ráadásul nem csak pontosabb, hanem teljesebb is volt a listája, mint a hagyományos keresönek, hiszen olyan szövegeket is megtalált, amelyeket a másik nem. A szöveges keresö ugyanakkor rosszabb eredményeket adott, köztük teljesen hibásakat is. Ezzel szemben a PubMed keresője ugyan helyes találatokat adott, ám mindössze tizenkét darabot.

\section{Második mérés}

A keresöbe írt kifejezés a következő volt: "cardiovascular risk prediction scores".

Az Aleetheia kulcsszavas algoritmusa itt is 75\%-os eredményt ért el, ám itt már a szöveges kereső is 73\%-os pontosságra volt képes. A PubMed itt azonban már csak $64 \%$-os teljesitményt mutatott.

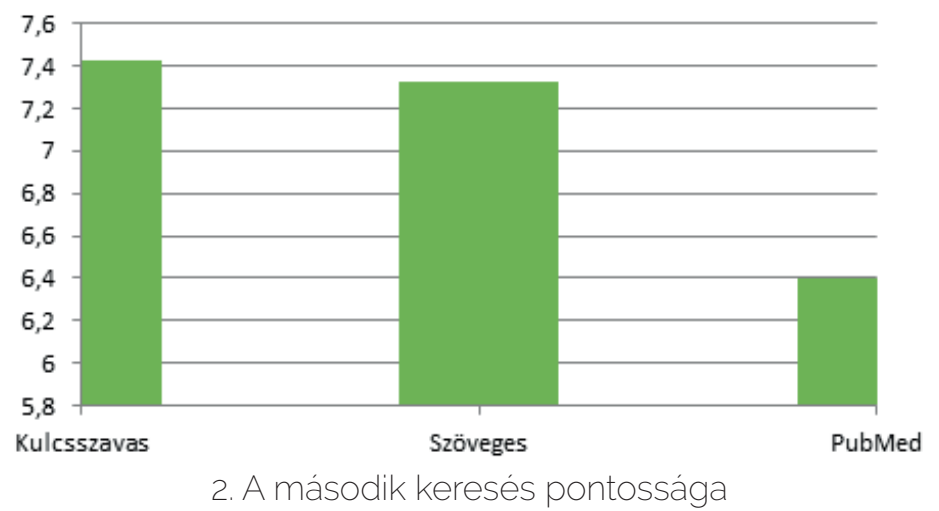


Az eredmények alaposabb elemzéséből az derül ki, hogy az Aleetheia kulcsszavas és a szöveges keresője is jó eredményeket hozott, ám a kétféle algoritmus nem ugyanazokat a jó találatokat jelenítette meg - bár metszete föleg a kiemelkedően jó találatok esetében volt a két listának. Ebböl arra a következtetésre jutottunk, hogy érdemes a kétféle keresés erényeit egyesiteni. A PubMed keresőjének kudarcát teljessége magyarázza. A keresett kulcsszavak sok dokumentumban felbukkantak és mivel a PubMed keresőjének természetes nyelvi szemantikus képességei nem voltak, igy számos hibás találat is bekerült a listába. Itt látszik, hogy a teljesség növekedése hogyan megy a pontosság kárára a hagyományos keresök esetében.

\section{Harmadik mérés}

A keresöbe irt kifejezés a következö volt: "microvesicles microparticles cardiovascular plaque".

Ezt a találati eredményt azért mutatom be, mert nagyon jól szemlélteti, hogy mik a különbségek a hagyományos kulcsszavas és a természetes nyelvek szemantikáján alapuló keresők között. Ha csak a listák pontosságát nézzük, akkor szigorú értelemben az Aleetheia kulcsszavas keresője ugyanolyan eredményre volt képes, mint a PubMed-é, szerény 30\%-os pontosságra, míg a szöveges kereső ennél is rosszabbra, $24 \%$-ra.

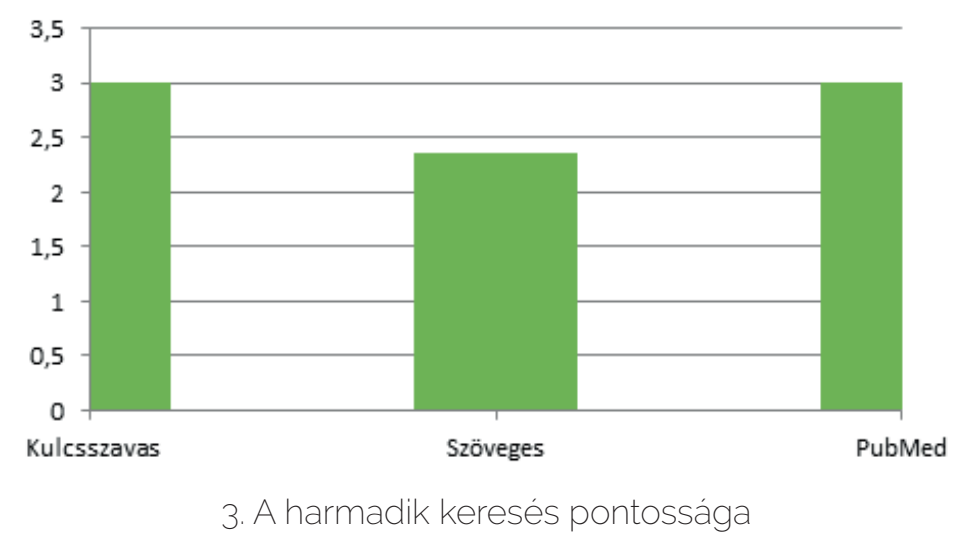

Az eredmények alaposabb tanulsága azonban lényegesen árnyalja a képet. A kulcsszavas keresők ugyanis csak azokat a találatokat jelenítik meg, amelyek minden kulcsszót tartalmazzák vagy pedig minden kulcsszóhoz tartalmazó metaadattal kapcsolatban vannak. Éppen ezért egyetlen, alacsony pontszámmal rendelkező szöveget jelenitenek meg. A szöveges azonban nem ebböl indult ki, így számos értékelhetetlen dokumentum mellett több olyat is adott, amelyeket a kutatók sokkal jobbaknak találtak, mint azt, amit a kulcsszavasak adtak. 


\section{Tanulságok}

Méréseink során több száz keresési listát elemeztünk és mindenhol hasonló eredményre jutottunk - eltekintve természetesen néhány mérési hibától és meglepö szélsőségtöl. Az Aleetheia algoritmusai 70-75\%-os pontosságra voltak képesek100\%-os teljesség mellett, míg méréseink szerint a hagyományos motorok, köztük a PubMed keresöje 60-65\%-os pontosságra 55-60\%-os teljesség mellett. ${ }^{5}$

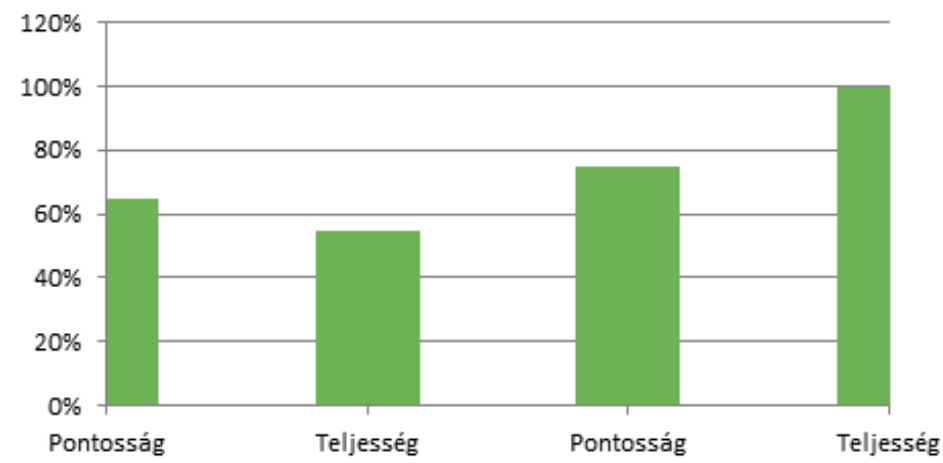

4. ábra Kékkel a PubMed, narancssárgával az Aleetheia keresőjének pontossága és teljessége

Az algoritmusok hibridizációjával azonban a pontosság lényegesen növelhető volt 90\% közelébe. Mindezt a költséges és időigényes metaadatolás nélkül sikerült elérnünk. Keresönk különösen jó eredményeket volt képes elérni azokban az esetekben, amelyekben mások nem tudtak. Ilyenek a hosszú szöveges keresések vagy pedig azok a kulcsszavas keresések, ahol a keresö kifejezés csak néhányszor fordult elö, így olyan dokumentumokat is érdemes voltátnézni, amelyekszemantikus kapcsolatban állnak a keresett szóval, de nem tartalmazták azt. Ez a kereséstípus meglepö és szokatlanul pontos eredményeket képes elérni a legnagyobb teljesség mellett.

\section{Összegzés}

Az Aleetheia a szemantikus keresés új lehetőségeit teremtette meg. Metaadatok használata nélkül is képes a korábbiaknál pontosabb találatokat adni. A termék hordozza azon elönyöket, melyeket terveztünk - azaz nyelvfüggetlenül müködik, mobil eszközön is megjelenithetö, gyors, és pontos keresési találatokat ad. Az orvosi alkalmazás kifejezetten jó teszteredményeket hozott, és tudományos-szakmai területen a PubMed adatbázison orvos-kutatóink továbbra is használhatják a saját kutatási területük újdonságainak megjelenitéséhez.

5 Az eredmény fontosságát mi sem bizonyítja jobban, mint az, hogy más keresők, igy a Google Scholar vagy a MEDLINE keresője sem képes ilyen eredményre (v. Ö.: [5] 


\section{Irodalomjegyzék}

[1] Bennett S Shenker, The accuracy of Internet search engines to predict diagnoses from symptoms can be assessed with a validated scoring system. International Journal of Medical Informatics, 83(2), 131-139, February 2014 doi: 10.1016/j.ijmedinf.2013.11.002

[2] Ovidiu Dan, Brian D. Davison, Measuring and Predicting Search Engine Users' Satisfaction, Journal ACM Computing Surveys (CSUR) Volume 49 Issue 1, July 2016 Article No. 18 doi: 10.1145/2893486.

[3] Udo Kruschwitz, Charlie Hull, "Searching the Enterprise", Foundations and Trends in Information Retrieval: 2017, Vol. 11: No. 1, pp 1-142. doi: $10.1561 / 1500000053$

[4] Iqra Safder, Saeed-Ul Hassan, DS4A: Deep Search System for Algorithms from Full-Text Scholarly Big Data 2018 IEEE International Conference on Data Mining Workshops (ICDMW) doi: 10.1109/ICDMW.2018.00186

[5] Bramer, W.M., Giustini, D. \& Kramer, B.M.R. Comparing the coverage, recall, and precision of searches for 120 systematic reviews in Embase, MEDLINE, and Google Scholar: a prospective study. Syst Rev 5, 39 (2016) doi: 10.1186/ s13643-016-0215-7 


\title{
MTA SZTAKI DSD - 25 éve a digitális könyvtárak szolgálatában
}

\author{
Kovács László, Micsik András \\ MTA SZTAKI Elosztott Rendszerek Osztály \\ laszlo.kovacs@sztaki.mta.hu, andras.micsik@sztaki.mta.hu
}

\section{Bevezetés}

25 évvel ezelőtt, 1994. január 1-én alapítottuk meg az MTA SZTAKI DSD, Elosztott Rendszerek Osztályt (dsd.sztaki.hu). Az osztály kezdetben, azakkori Magyarországon még újdonságnak számító World Wide Webes technológiák hazai bevezetésében, elterjesztésében volt úttörö. Az ország első webszolgáltatásai (pl. SZTAKI Szótár), kormányzati honlapjai (www.kormany.hu, www.kancellaria.gov.hu), webes müalkotásai (pl. Nightwatch, SZTAKI Gallery) létrehozása mellett gyorsan kialakult az a tematikus profil, mely azóta is töretlenül jellemzi az osztály kutatás-fejlesztési tevékenységét. Ebben a szakmai profilban az (elosztott) digitális könyvtári és archivum rendszerek kutatás-fejlesztése kiemelkedö és meghatározó szerephez jutott és jut a mai napig is, a digitális könyvtárak az MTA SZTAKI DSD osztály alapvető, szakmai identitásképző témaköre.

A 25 év során elért szakmai eredményeinket áttekintve, néhány jelentősebb, a témakörbe eső projektet mutatunk be, konkrét szakmai feladatok köré csoportosítva azokat.

\section{A keresés aspektusai}

A digitális könyvtárak a World Wide Web elterjedésének egészen korai szakaszában megjelentek (sőt, voltak FTP és Gopher alapú digitális könyvtárak is, de ki emlékszik már rájuk?). Akkoriban azonban még nem voltak univerzális webes keresök (lásd Google), és igy a több helyen egyszerre történő, elosztott keresés igénye hamar felmerült. A számítástechnika és számítógéptudomány diszciplinán belül az első digitális könyvtár az USA-ban épült meg és az NCSTRL ${ }^{1}$ (Networked Computer Science Technical Report Library) nevet kapta. Az NCSTRL elosztott rendszerként egymáshoz kapcsolt könyvtári csomópontok hálózata volt, melyben egy elosztott keresési algoritmus alapján lehetett megtalálni a keresett digitális objektumokat (kutatási jelentéseket, tudományos cikkeket, publikációkat). A DSD osztály megalakulásával szinte egyidejüleg még 1995-ben felállitottuk az MTA SZTAKI-ban az NCSTRL első európai csomópontját és bekapcsoltuk az NCSTRL hálózatba. A rendszer az elosztott és központi keresési módszereket kombinálta, és sok azóta alapvetőnek tartott szolgáltatást vezetett be, mint például egységes API, perzisztens linkek stb. és a hamarosan megjelenő OAI-PMH protokoll is sokban hasonlit erre a korai API-ra.

A digitális könyvtári kutatási területen Európa jelentösen elmaradt az USA mögött, amit az Unió a DELOS LTR (Long Term Research) ESPRIT projekt inditásával igyekezett behozni. A DELOS LTR projekt alapkutatási projektként meghatározó szerepet játszott abban, hogy Európában létrejött a digitális könyvtári szakmai témakörrel foglalkozó kutatók és fejlesztők nemzetközi közössége, és 
megteremtődött az európai digitális könyvtári kutatások humán erőforrás alapja, egyben akkor jelentős pénzügyi forrásokat, támogatást is kapott e szakmai terület. Az MTA SZTAKI DSD a kezdet kezdetén történő részvétele a DELOS LTR projektben tette lehetővé azt, hogy elkezdődjön Magyarországon is a digitális archivumok kutatása és fejlesztése, immáron harmonikusan beágyazva az európai digitális könyvtári K+F eröfeszitésekbe. Később az MTA SZTAKI DSD folyamatosan jelen volt az európai digitális könyvtári kutatói közösségben a DELOS NoE, illetve a DELOS NoE2 európai (FP4 és FP5) projektek tagjaként és számos más hazai és nemzetközi $\mathrm{K}+\mathrm{F}$ projektben kamatoztathatta az európai szinten kifejlesztett, illetve az ott elsajátított technológiákat, müszaki megoldásokat.

Az MTA SZTAKI az ERCIM (European Research Consortium for Informatics and Mathematics) konzorciumba való belépése után jelentős szerepet kapott az ERCIM saját elosztott digitális könyvtári rendszerének létrehozási folyamatában. Elkészült az ETRDL ${ }^{2}$ (ERCIM Technical Reference Digital Library), melyben az MTA SZTAKI hazai csomópontot üzemeltetett és az ETRDL (Európa) - NCSTRL (USA) kapcsolat létrehozásáért volt felelős. Később az ETRDL technikai alapjain készitettük az AQUA keresőnket, amely korai Java applet technológiával az ismétléses finomitás (iterative refinement via facets) keresési módszert támogatta³.

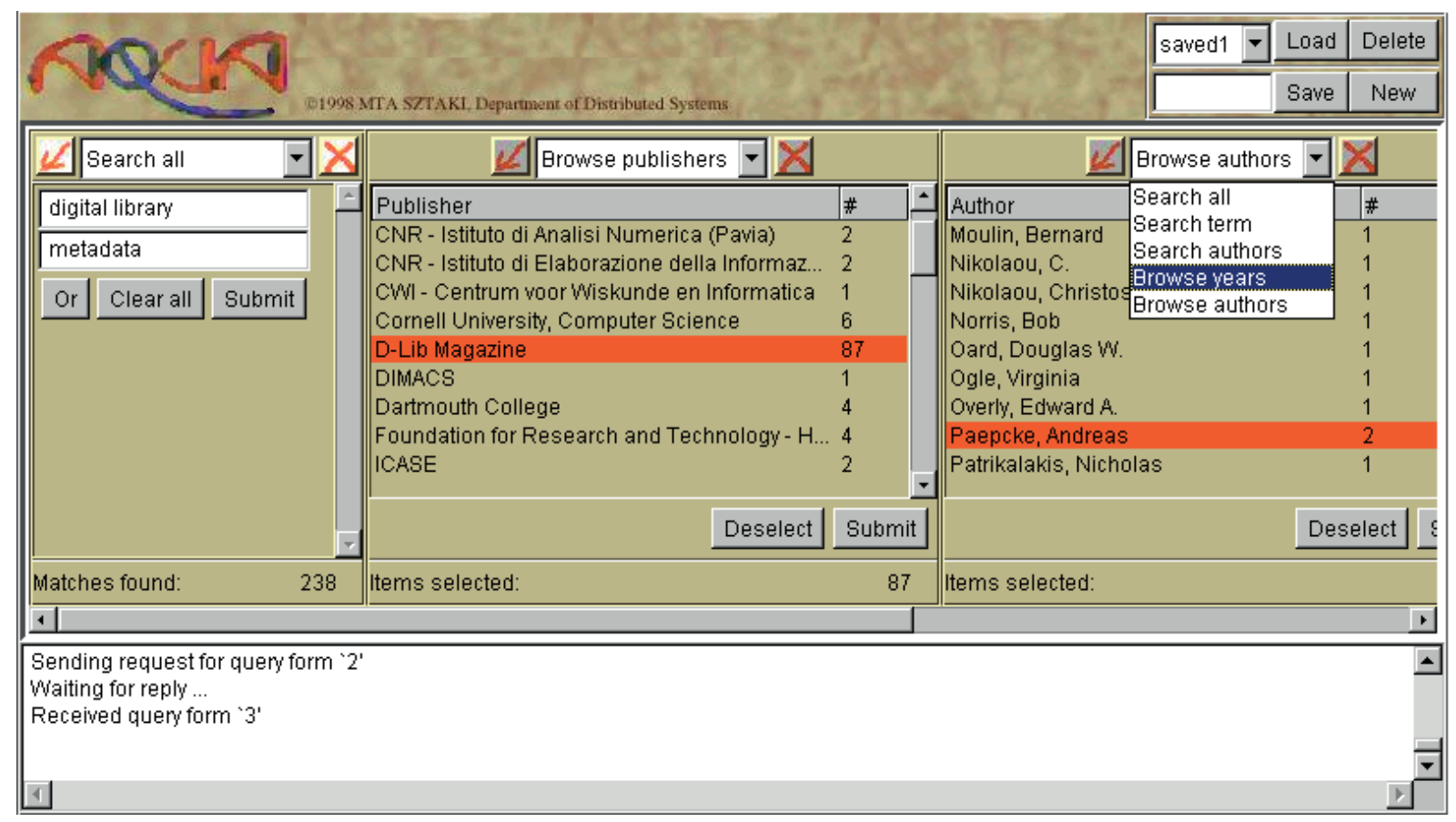

1. ábra: Az AQUA keresöfelület 1998-ból

\footnotetext{
$2 \quad$ A. Andreoni et al:: The ERCIM Technical Reference Digital Library. D-Lib Magazine December 1999

3 L. Kovács, A. Micsik, B. Pataki: AQUA: query visualization for the NCSTRL digital library. Proceedings of the fourth ACM conference on digital libraries. Berkeley, 1999.
} 
A nagy keresömotorok hatására a központositott keresöszolgáltatások váltak népszerüvé, mivel gyorsabbak és megbízhatóbbak voltak elosztott társaiknál. Ezek elterjedését roppant mód felgyorsitotta az OAI-PMH protokoll, melyet elöször a magyar OSZK-SZTAKI Hektár ${ }^{4}$ projekten belül próbáltunk az OSZK MEK-kel együtt itthon népszerüsíteni. A Hektár projektben kialakitott kereső megoldás az általunk kifejlesztett NDA@SZTAKI digitális könyvtári rendszer felületen is megjelent, mely az időközben hasonló elvek mentén megvalósult Nemzeti Digitális Adattár alternatív keresöfelülete volt. Ez a szolgáltatásunk jelenleg az OAI kereső 5 nevü reinkarnációjában él tovább, és a nyiltt teljes szövegü repozitóriumok és folyóiratok közös, országos keresőfelületét nyújtja.

Továbbra is foglalkoztatott minket azonban az elosztott digitális könyvtárak és archívumhálózatok problémaköre, és a kis- és közösségi rádiózás szükségleteinek megfelelő peer-to-peer elosztott rádióarchívum-hálózatot fejlesztettünk ki a StreamOnTheFly EU projektben ${ }^{6}$. Itt a csomópontok meghatározhatták nyelvi, regionális, vagy bármely más alapon, hogy mely más csomópontokkal cserélnek metaadatokat.

A StreamOnTheFly európai hálózat több mint 10 éven keresztül üzemelt megbizhatóan és biztositotta az európai közösségi rádiócsatornák archiválási igényeit, illetve a csatornák közötti müsorcserét, mintegy virtuális, ingyenes piacteret hozva létre a multimédia (leginkább audió) tartalmak kicserélésére és újrafelhasználására. A kis- és közösségi rádiócsatornák ugyanis mindig is eröforráshiánnyal küzdöttek, ezért a StreamOnTheFly hálózat jelentősen hozzájárult e csatornák mindennapi takarékos müködéséhez, fennmaradásához.

A StreamOnTheFly hálózat felbomlása után több mint 10 évvel digitális "maradványként" a radio.sztaki.hu oldalon ma is belehallgathatunk magyar városi rádiók korábban archivált müsoraiba.

A nem szöveges média formátumok (audió, kép, videó stb.) terjedésével az ezekben való keresés lett az aktuális probléma. Az MTA SZTAKI CrossMedia projektünkben a képi információk és metaadatok (szemantikus) keresésének kombinálási lehetőségeivel kisérleteztünk ${ }^{8}$.

Végső soron a plágiumkeresés is egy ilyen újfajta keresési technika, amely sokféle dokumentumformátumból kivonja a szöveget, és észleli az egyező szövegrészeket a különböző dokumentumokban. Az MTA SZTAKI KOPI9 plágiumkeresőjét 2004-ben

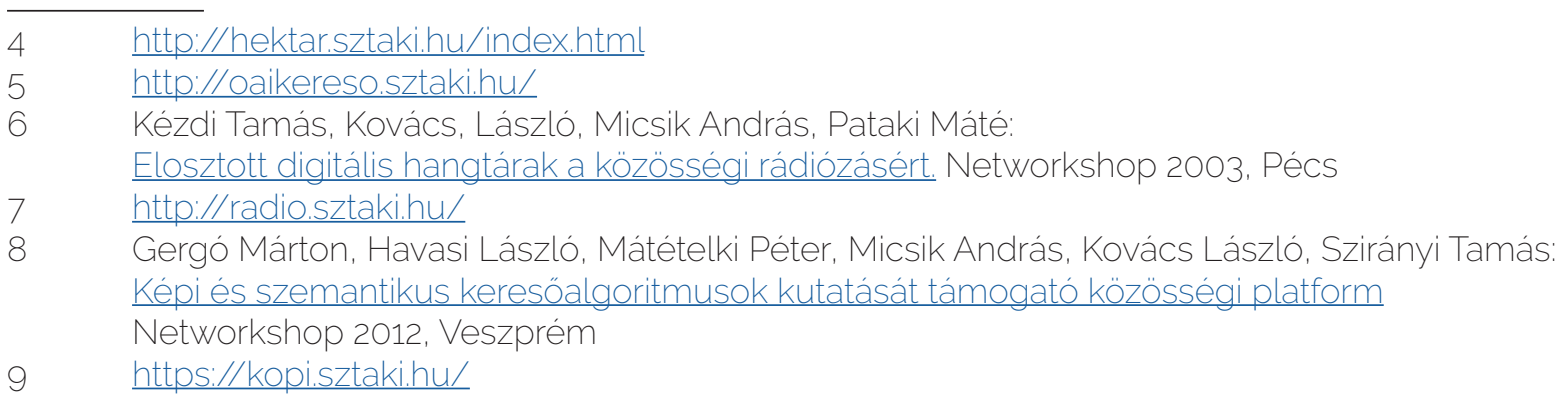


hoztuk létre, és azóta üzemeltetjük. Ez volt az első plágiumkereső Magyarországon, amely jól kezelte a magyar nyelvü szövegeket, és késöbb 2011-ben, a világon elsőként, valósitott meg jó minőségü forditási plágiumkeresést ${ }^{10}$ is, amely például detektálni tudta, ha valaki a dolgozatába az angol nyelvü Wikipedia-ból magyarra forditott szövegrészeket illesztett be.

\section{Metaadatok, dokumentumok, kapcsolt adatok}

Az 1998-ban megjelent Dublin Core (DC) metaadatleíró rendszer forradalmasította a metaadatok világát. A Dublin Core megnyitotta az utat az eddig egymástól elkülönülve fejlődő leíró rendszerek (mint például a MARC), átjárhatóvá, egymásra leképezhetővé tételére, meghatározva a leglényegesebb, esszenciális metaadatok legszükebb körét. Kezdetben úgy képzelték, hogy az egyes szakágak (pl. kereskedelem, könyvtárak, közigazgatás stb.) mind kialakitják a DC, majd késöbb qDC alapú, de specializált változataikat, az ún. alkalmazási profilokat (application profile). Ezekszabványositására, áttekintésére és kényelmes, grafikus szerkesztésére szolgált az azonos nevü EU projekt keretében létrehozott CORES rendszer, melynek fejlesztésében segédkeztünk, és melyet sokáig üzemeltettünk ${ }^{11}$.

Az alkalmazási profilok szakmai körökben történö lassú terjedésével egyidejüleg megjelent egy alapvetöbb - persze bonyolultabb - koncepció, a Szemantikus Web, amellyel egyszerü metaadatrekordokat, tezauruszokat és logikai modelleket (ontológiákat) egyaránt le lehetett írni. A cél tehát az lett, hogy minden területen létrejöjjön a tudásreprezentációhoz szükséges ontológiák megfelelő halmaza. A Szemantikus Web késöbb egyszerübb és hatékonyabb formában kapcsolt adatok (linked data (LD), linked open data (LOD)) néven indult rohamos fejlödésnek.

A kapcsolt adatokat a már korábban emlitett CrossMedia projektben használtuk szemantikus keresésre, vagyis konkrét szóelőfordulások helyett egy tezaurusz részgráfja alapján kerestünk (pl. szinonimák, hiponimák bevonásával) megfelelő képeket.

2011-ben elindult a lod.sztaki.hu szolgáltatás az Intézetben, amely az OAI alapon összegyüjtött hazai kulturális adatokból előállitott kapcsolt adathalmaz szolgáltatás, és több mint 11 millió egyszerü tényböl (RDF triple) áll össze.

Végül 2016-ban, a COURAGE EU projekt indulásával sikerült egy a kezdetektöl és alapjaiban is kapcsolt adatos (RDF alapú) adattár-megoldást létrehoznunk.

Teljes rendszerek fejlesztése és üzemeltetése

A fejlesztések mellett mindig is szerettük, ha a szoftvereink müködnek és széles körben használják is azokat. Ezért fokozott gondot forditottunk az üzemeltetésre és a folyamatos fenntartásra, támogatásra. Néhány komplexebb rendszert kiemelnénk a létrehozott szolgáltatás-portfóliónkból.

\footnotetext{
10 Pataki Máté: Plágiumkeresés különbözö nyelvek között. Networkshop 2011, Kaposvár

11 Fülöp Csaba, Kovács László, Micsik, András

Metaadatsémák nyilvántartása szemantikus web alapon. Networkshop 2004, Györ
} 
A már emlitett StreamOnTheFly európai rádióarchivum rendszer több csomópontból álló, elosztott rendszervolt, ahol az egyes csomópontok dönthettek arról, hogy mely más csomópontokkal lépnek partnerségre. Egy csomóponton belül több "rádióadó" archiválhatta müsorait, a szerkesztői jogok szabályozásával akár sorozatonként más-más ember végezhette kényelmesen a hanganyagok, metaadatok feltöltését és/vagy szerkesztését. A felhasználók pedig saját, akár több órás egyéniesitett (perszonalizált) rádiómüsort állithattak össze az archivumból és stream formájában élvezhették azt.

A KOPI plágiumkereső is összetett osztott rendszer, mivel a keresés összetett belső folyamatának lépéseit különböző célszerverek végzik. A SZTAKI Szótár is ide kivánkozik, bár az csak szavak archivuma, de napi 80-100 ezer látogatót szolgál ki 8-10 szerver precíz együttműködésével. A szótár tartalmak tárolását pedig egy gráfadatbázis (neo4j) szolgálja ki. A SZTAKI Szótár kapcsán érdemes megjegyeznünk, hogy itt gondosan ügyeltünk a szótári keresö URL-ek hosszútávú megörzésére. Ezért, ha valaki 1995-ben a szótár indulásakor berakott egy linket (keresést) egy szóra a honlapjára, ha erre ma 2019-ben ráklikkelnek, akkor a szótár ma is megadja a megfelelő forditást.

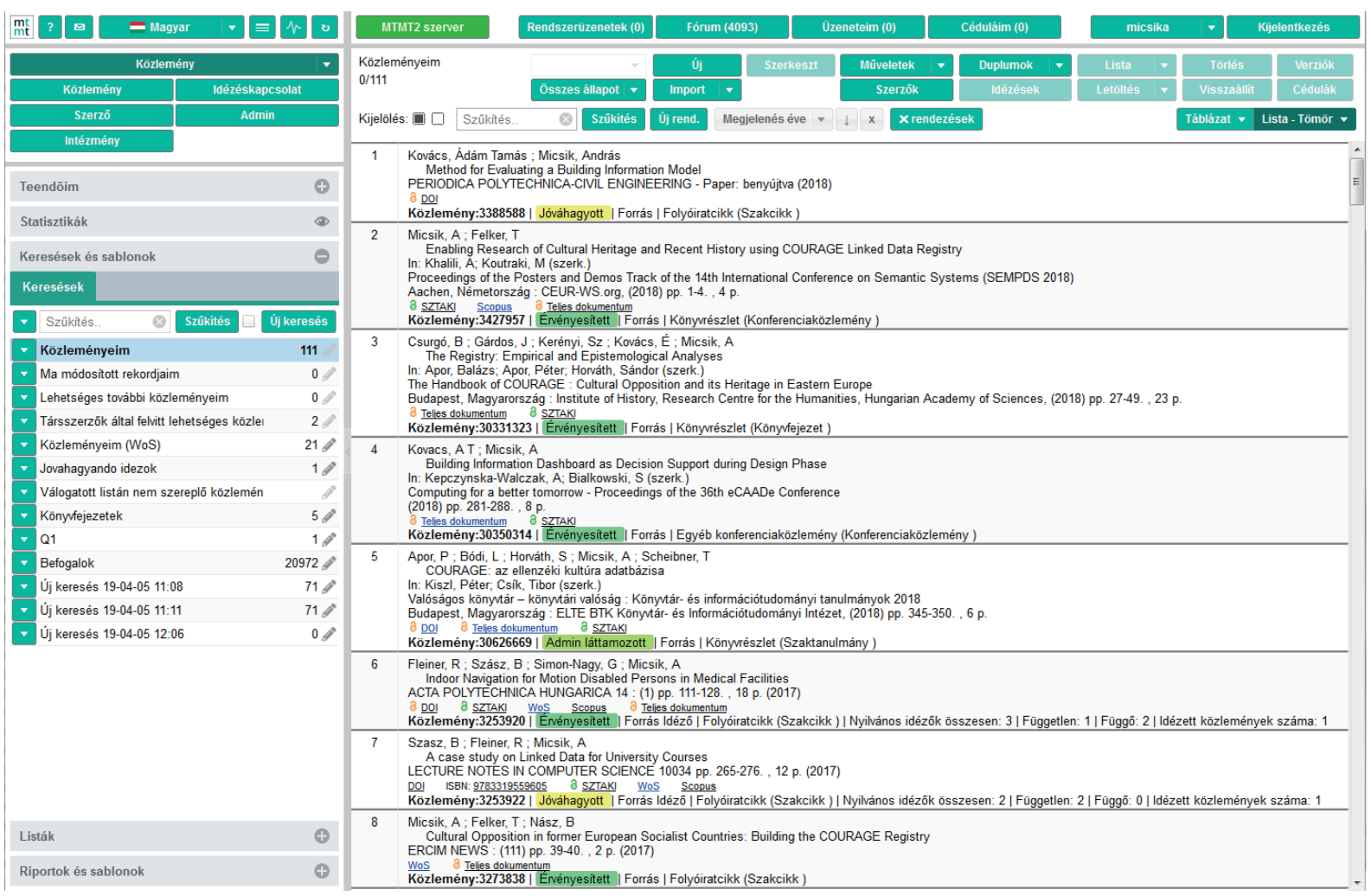

2. ábra: Az MTMT2 szerkesztői felülete 
AzMTASZTAKIElosztott Rendszerek osztályán fejlesztettük kia MagyarTudományos Müvek Tára 2018. novembere óta éles üzemelésü 2-es (MTMT2) szoftververzióját ${ }^{12}$. Ez volt pályafutásunk során eddig a legbonyolultabb és legnagyobb saját fejlesztésü szoftver-rendszer. Az MTMT2 a külvilággal egy REST API-n keresztül kommunikál, ezt használja a teljesen új nyilvános felület, amelyen bejelentkezés nélkül akár mobilon is lehet böngészni a szerzök, csoportok munkásságát, vagy az egyes témakörökben megjelent cikkeket. A szerkesztöi felület ún. egyablakos Javascript alkalmazás, amely egy teljes professzionális munkakörnyezetet (workspace) ad a közlemények felviteli, kiegészitési stb. teljes körü adatkurátori feladatainak elvégzésére. Az MTMT2 rendszert több mint 60.000 felhasználó, az ország teljes kutatói szférája használja rendszeresen.

Végezetül a COURAGE ${ }^{13}$ EU projekt keretében az általunk létrehozott digitális archivum rendszerét említjük meg, amely a technikai fejlettségével emelkedik ki. Az adatokat RDF triple store tárolja a külön e célra készült COURAGE ontológia, mint adatséma alapján. A felhasználói felület nagy részét is kapcsolt adat konfiguráció, illetve SPARQL lekérdezések vezérlik. Az adatfelvitel során egyböl létrejönnek a kétirányú adatkapcsolatok, relációk, melyek mentén a létrehozott szemantikus tudásgráf sokoldalúan böngészhetö. A rendszergazda pedig menet közben a rendszer leállása nélkül fel tud venni új adatmezöket, vagy meg tudja változtatni a meglévőket (séma módosítás), azok megjelenési módját is beleértve.
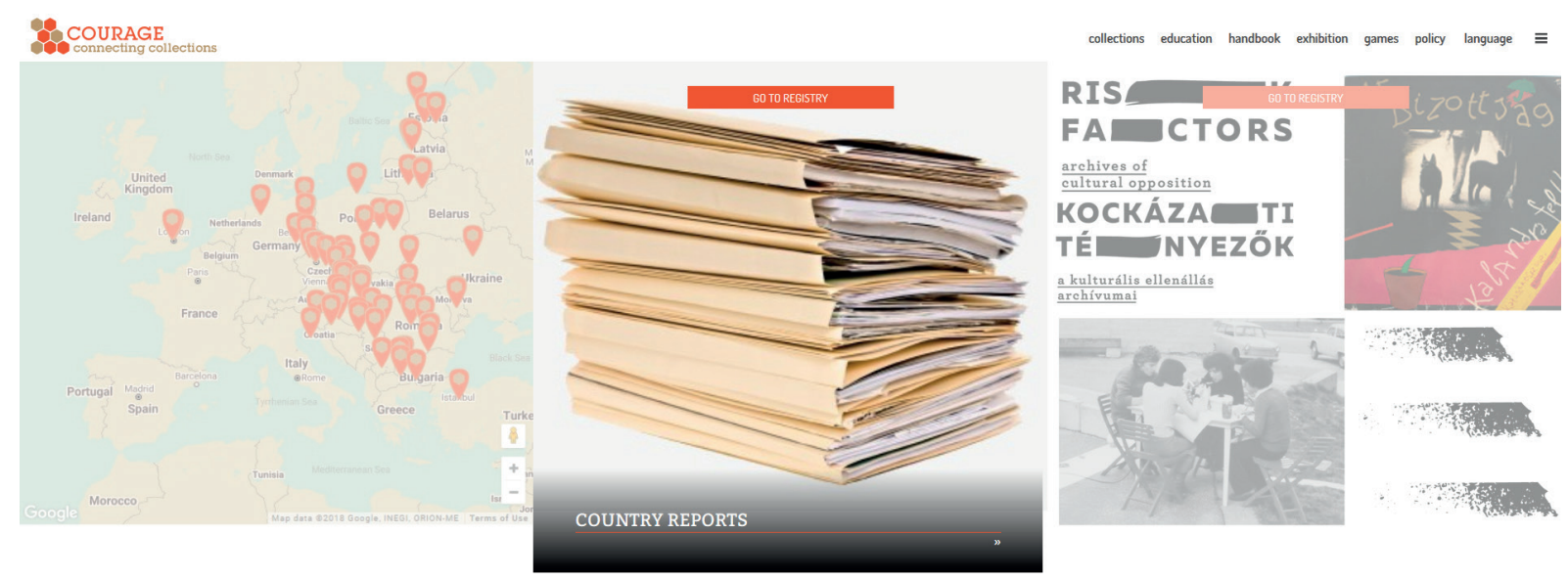

Connecting collections

Cultural Opposition - Understanding the Cultural Heritage of Dissent in the Former Socialist Countries

3. ábra: A COURAGE projekt honlapja

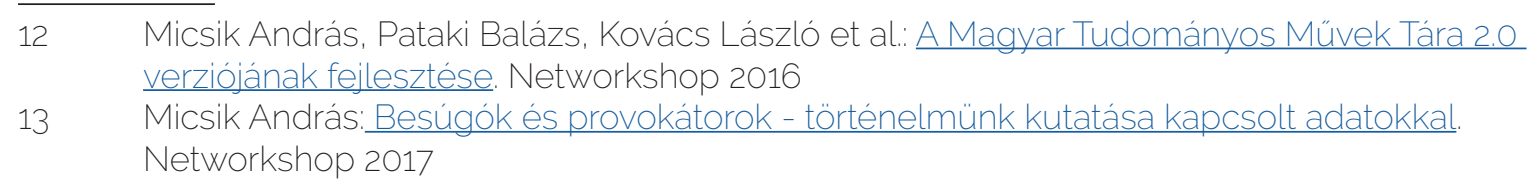


Utószó

AzMTASZTAKIDSD, a kutatóintézet Elosztott Rendszerek Osztálya 25éven keresztül töretlenül dolgozott a digitális könyvtárak és archívumok kutatás-fejlesztése területén és létrehozott egy egyedülálló tudás és technológiai megoldás portfoliót, mely jelenleg a teljes magyar felhasználói közösség szolgálatára áll. A jövöben szeretnénk tovább foglalkoznia tudásreprezentáció és tudásfúzió felmerülő elméleti és gyakorlati problémáival. A portfolióban nem csupán korábbi megoldásaink, illetve az elsajátított technológiák, know-how-k stb. reprezentálnak értéket, hanem az az időközben az osztályon kialakitott képességünk, mely bonyolult müszakitudományos problémák kezelését holisztikusan szemlélve egyidejüleg képes akár felfedező, alkalmazott kutatási és fejlesztési tevékenységeket kombináltan végezni. Az osztály munkatársai e képesség birtokában bátran vállalkoznak bármely új kihivás esetén egy lehetséges, a gyakorlatban müködő, korszerü és tudományosan is értékelhető megoldást megtalálni. 


\title{
A múzeumi adatreprezentáció és közzététel formái a Közgyüjteményi Digitalizálási Stratégia keretében
}

\author{
Kómár Éva \\ Magyar Nemzeti Múzeum \\ komar.eva@mnm.hu
}

\begin{abstract}
The museum data representation and publication included in the Public Collection Digitalisation Strategy The directions of the Hungarian cultural heritage digitalization are set by the Public Collection Digitalisation Strategy (KDS) until 2025, in which the most important goal is to provide digital content based on the common principles of the public collections for the broader society. One of the basic requirements of providing services, unifying heterogeneous resources, is that a data mapping should be available between data models used in public collection branches, and the forms and tools of data representations should be in synergy. Although different disciplines, like museology, usually use their own datamodels and publication schemas. This presentation examines, what steps should museums take, to meet the requirements in connection with providing content, defined in KDS. How can they get from current practises (just making publications focusing on descriptive data) to creative applications provided with extra informations, which satisfy user needs. Furthermore it will be presented, how can museum collection management systems connect to common platforms based on cooperation, like the Hungarian National Namespace Project or the search service of the National Repository Project.
\end{abstract}

\section{Bevezetés}

A hazai kulturális örökség digitalizálásának irányait 2025-ig a Közgyüjteményi Digitalizálási Stratégia (KDS) ${ }^{1}$ jelöli ki, melynek egyik legfontosabb célja, hogy a közgyüjtemények egységes elvek alapján müködö digitális tartalomszolgáltatást valósitsanak meg a társadalom minél szélesebb rétegei számára. A heterogén forrásokat egységesitő szolgáltatások biztositásának egyik alapfeltétele, hogy a közgyüjteményi ágakban használt adatmodellek közelítsenek egymáshoz, az adatreprezentációk formái és eszközei szinergiában legyenek. Ugyanakkor a különböző diszciplínák, így a múzeumi terület is, jellemzően saját adatmodellekben és publikációs sémákban gondolkodnak.

Jelen írás azt vizsgálja, hogy a múzeumoknak milyen lépéseket kell tennie ahhoz, hogy a KDS-ben megfogalmazott tartalomszolgáltatási követelményeknek megfeleljenek. Hogyan juthatnak el a jelenlegi gyakorlattól - a csupán a nyilvántartási adatokra koncentráló publikálástól - a széles felhasználói igényeket kiszolgáló, plusz információkkal ellátott kreativ alkalmazásokig. Továbbá bemutatja, hogy a múzeumi gyüjteménykezelö rendszerek hogyan kapcsolódhatnak olyan együttmüködésre épülő közös platformokhoz, mint a Magyar Nemzeti Névtér Projekt vagy a Nemzeti Adattár Projekt keresőszolgáltatása.

1 Közgyüjteményi Digitalizálási Stratégia (2017-2025). Hozzáférés: 2019.06.30. https://www.kormany.hu/download/9/ac/11000/K\%C3\%B6zgy\%C5\%B1jtem\%C3\%Agnyi\%20 Digitalizl\%C3\%A1si\%20Strat\%C3\%Aggia_2017-2025.pdf 


\section{Digitalizálás a múzeumokban}

Ha visszatekintünk az elmúlt tiz évre, láthatjuk, hogy a múzeumi szféra a közgyüjteményi digitalizálás területén egyre nagyobb ütemben igyekszikfelzárkózni a könyvtári és a levéltári szakágakhoz. A múzeumokjelentős része elkezdett digitális nyilvántartást vezetni, megjelentek az intézményi webes katalógusok, virtuális kiállitások születtek, látványos kreatív megoldások a kiállitási terekben, és több múzeum sikeresen kapcsolódott valamelyik Europeana által inditott projekthez. A hazai múzeumi ágazat digitalizálási gyakorlatára ugyanakkor jellemző, hogy a mai napig sem a metaadatokra, sem a digitális objektumokra nincsenek egységesen alkalmazott szabványok. A felsorolt eredmények többségükben szigetszerü vállalkozások, amelyekböl nincs átjárás más muzeális intézmények, vagy más közgyüjteményi ágak szolgáltatásaihoz.

\subsection{A digitalizálás célja}

A digitalizálás célja a múzeumokban elsősorban a digitális nyilvántartás vezetése, az archiválási szándék és a kutatói kör kiszolgálása. Ahogy az 1. ábrán is látható a digitális tartalmak hasznosulását tekintve egyértelműen az állományvédelmi rangsor érvényesül a közzétételi igényekkel szemben.

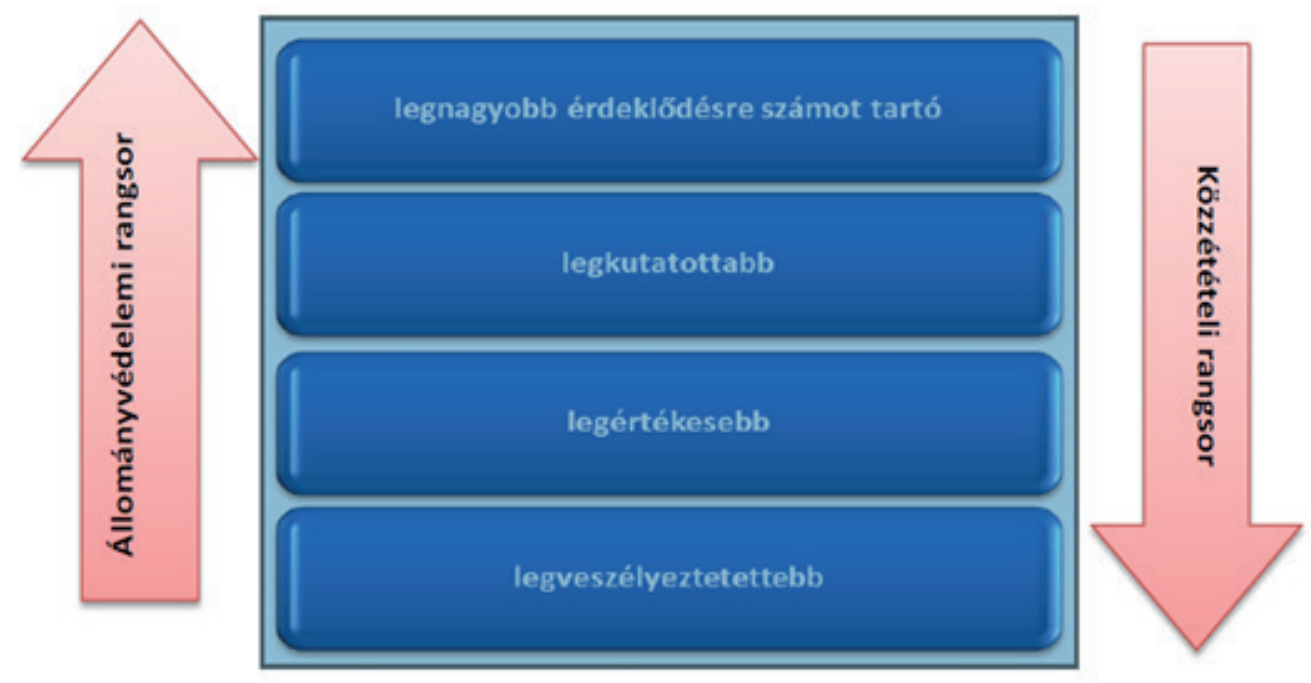

1. ábra A digitális tartalmak hasznosulási modellje (forrás KDS, 2017)

Egy, az OMMIK² által 2017-ben végzett országos felmérés is bizonyitja, hogy a múzeumi adatbázisokban a képpel rendelkező rekordok száma rendkivül alacsony a szöveges rekordok arányához képest (17\%), továbbá a publikus rekordok aránya az összes digitalizált rekordok állományához képest szintén elenyésző (11\%).

\footnotetext{
2 Országos Muzeológiai Módszertani és Információs Központ, a Magyar Nemzeti Múzeum föosztálya
} 

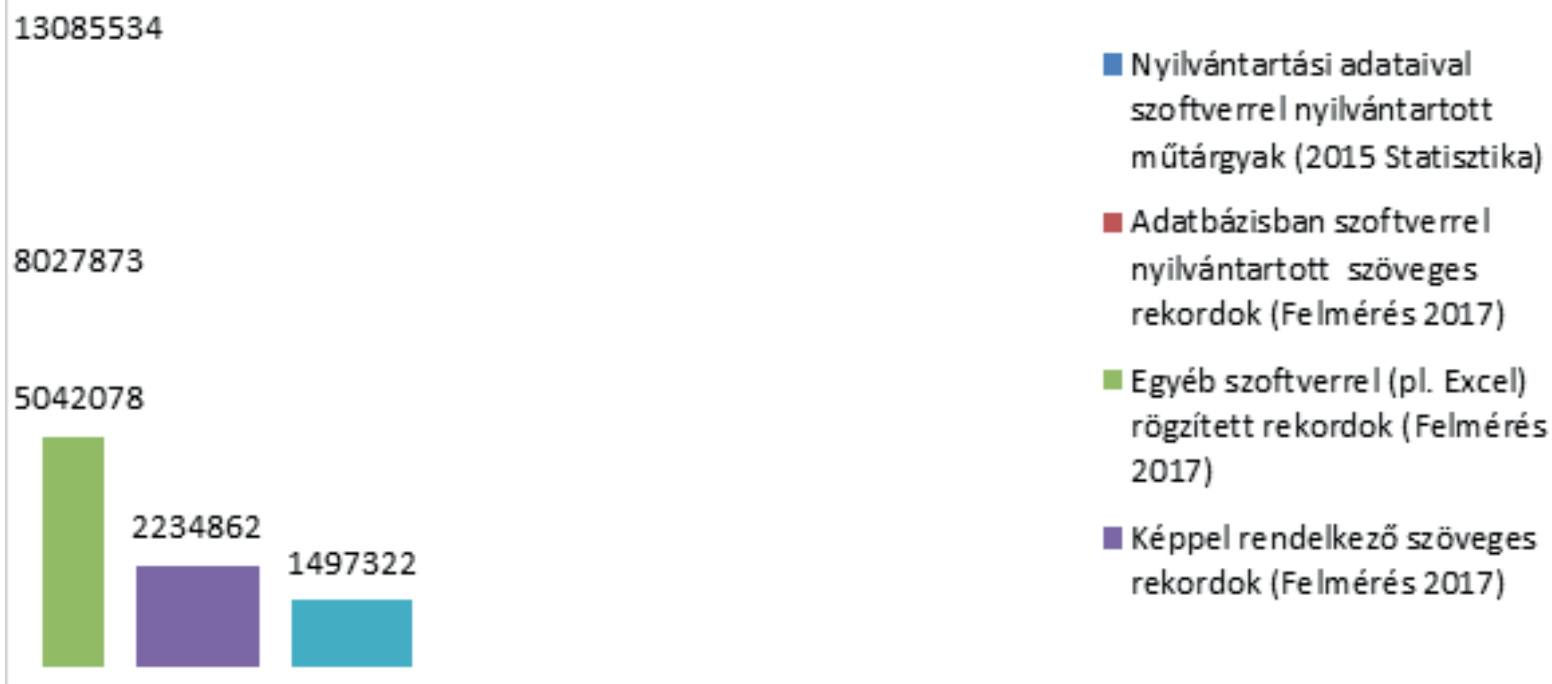
szoftve rrel nyilvánt artott mútárgyak (2015 Statisztika)

n Adatbázisban szoftverrel nyilvántartott szöveges rekordok (Felmérés 2017)

Egyéb szoftverrel (pl. Excel) rögzitett rekordok (Felmérés 2017)

- Képpel rendelkezõ szöveges rekordok (Felmérés 2017)

2. ábra Szöveges és képes rekordok aránya a digitális nyilvántartásokban, 2017-es felmérés

\subsection{Múzeumi adatbázisok}

Bár egyre több múzeum használ már valamilyen elektronikus nyilvántartást, a metaadatok nagy része még valamilyen táblázatkezelő szoftverrel képződik. A gyüjteménykezelő rendszerek heterogén képet mutatnak, a "dobozos” termékek mellett sok a helyi fejlesztés is, ugyanakkor ezekben az adatbázisokban biztositott a strukturált adattárolás és a szabványos kimeneti formátum.

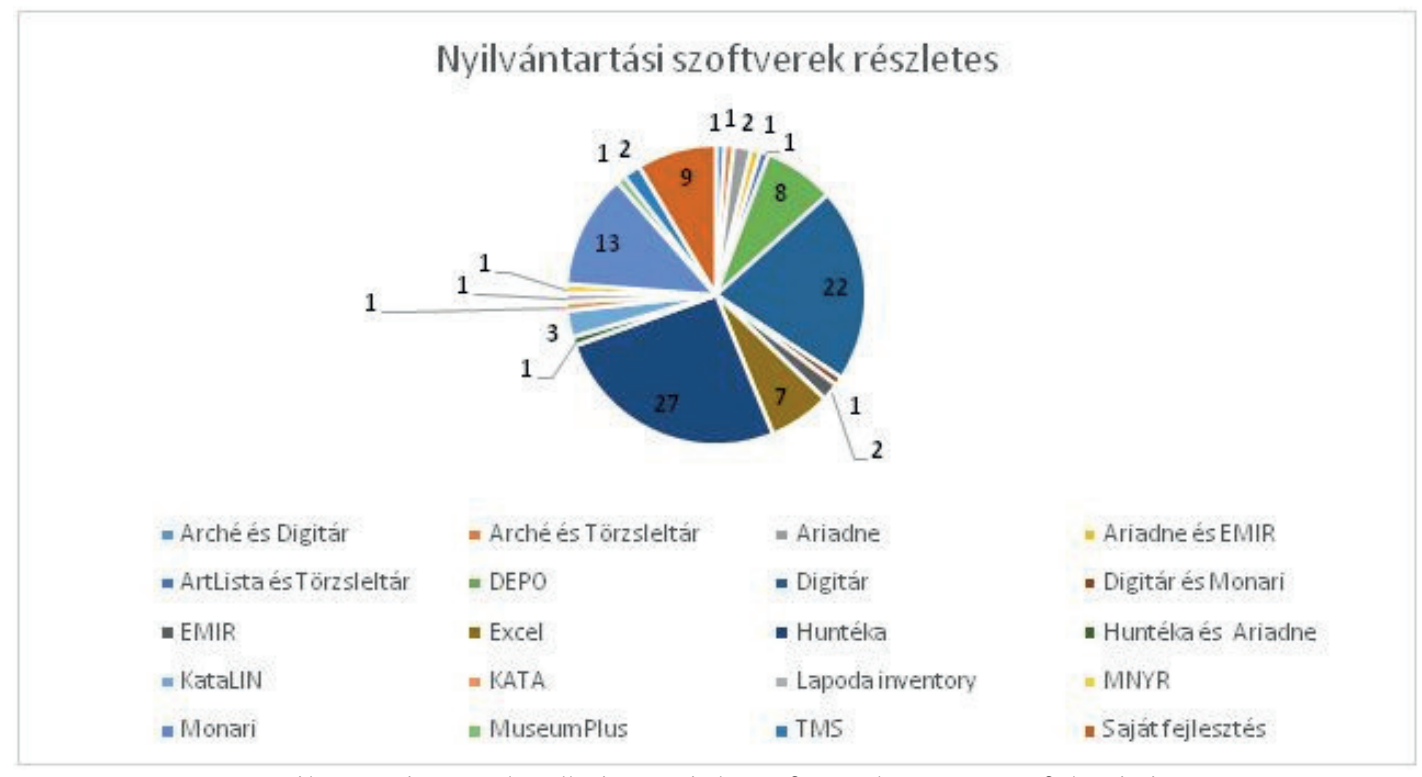

3. ábra Múzeumi nyilvántartási szoftverek, 2017-es felmérés

A nemzetközi gyakorlatban létezik speciálisan a múzeumok számára készült harvesztálási-adatcsere formátum (LIDO3), ám közös projektek hiányában hazai területen mégsem terjedt el a használata.

3 Lightweight Information Describing Objects. Hozzáférés: 2019. 06. 30. http://network.icom.museum/cidoc/working-groups/lido/what-is-lido/ 


\subsection{Digitális objektumok}

A gyüjteményi digitalizálás első szakaszában az intézmények többsége a legértékesebb és a leginkább keresett mütárgyairól készitett másolatot. A jó minőségü mesterpéldányok alkalmasak a nyomdai célú továbbforgalmazásra. A későbbi szakaszokban, a tömeges digitalizálással elöállított példányok többsége azonban csupán a mütárgyak beazonosítására szolgál, a digitális objektumok közül kevés a jó minőségü, élményszerü felhasználást biztosító médiatartalom. A bevételkieséstöl tartva a múzeumok nem szivesen publikálják online térben a mütárgyak digitális másolatait, föleg nem nagy felbontásban. Leginkább a tartalmakhoz való hozzáférést tekintve jelentős a múzeumi terület lemaradása a többi ágazathoz képest: 2016-ban az összes digitalizált múzeumi állományból csak 9\% volt hozzáférhető a felhasználók számára. ${ }^{4}$

\subsection{Leíró metaadatok}

A hazai múzeumi területen jelenleg nincs hivatalosan elfogadott metaadatszabvány. A gyüjteménykezelö rendszerekben található leíró metaadatokat a ma már igencsak elavultnak tekinthető 20/2002. (X.4.) NKÖM rendelet5 alapján képzika muzeológusok. A rendeletnek megfelelően rögzitett adatok csak a nyilvántartáshoz szükséges információkat tartalmazzák. A publikus metaadatok köre ennél még szükebb, sokszor hiányoznak a részletes leírások, így a rekordok nem elég informativak.

A fentiekböl következik, hogy az online térben elérhetö múzeumi tartalmak az átlag felhasználó igényeit nem elégíti ki. Hiába tesszük közzé egy fibula vagy egy mángorló rekordját, olyan adatmezőkkel, amelyek a beazonositást szolgálják (megnevezés, anyag, technika, méret), ennyi információból még nem derül ki, hogy mi is az a tárgy és mire használták.
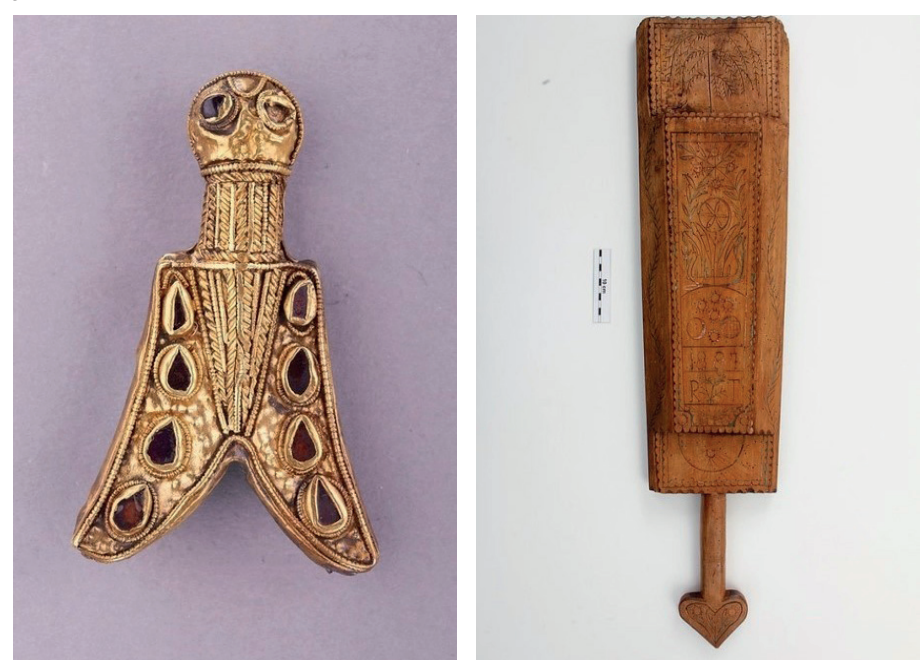

4. ábra Egy fibula és egy mángorló rekordja a MuseuMap portálon http://resolver.museumap.hu/object/5859436 http://resolver.museumap.hu/object/5984036

\footnotetext{
4 Közgyüjteményi Digitalizálási Stratégia (2017-2025). Hozzáférés: 2019.06.30. https://www.kormany.hu/download/g/ac/11000/K\%C3\%B6zgy\%C5\%B1jtem\%C3\%Agnyi\%20 Digitalizl\%C3\%A1si\%20Strat\%C3\%Aggia_2017-2025.pdf

5 20/2002. (X. 4.) NKÖM rendelet a muzeális intézmények nyilvántartási szabályzatáról. Hozzáférés: 2019.06.30. https://net.jogtar.hu/jogszabaly?docid=a0200020.nkm
} 


\section{2. Új típusú elvárások}

Az előzőekben leirtak azért is jelentenek problémát, mert a KDS a közzétételt, a közzétételi célú digitalizálást hangsúlyozza, ennek érdekében jó minőségü, az átlag felhasználó számára is informativ digitális tartalmak létrehozását várja el. Szolgáltatásorientált szemléletet kiván megvalósitani, melynek során a közgyüjteményi digitális tartalmak elsősorban az oktatás/köznevelés, de a továbbiakban a turizmus, a rekreáció területén is hasznosulnak, végsö soron hozzájárulva az állampolgárok jobb életminőségéhez.

Ahhoz, hogy a múzeumok meg tudjanak felelni a KDS-ben megjelölt közzétételi kivánalmaknak, előfeltétel, hogy rendelkezzenek megfelelő mennyiségü és minőségü digitálisan elérhető tartalommal, és ezekhez hozzáférést is biztositsanak különböző platfromokon. A tartalomelóállitást tekintve alapvető szemléletváltásra van szükség, azaz az intézményi digitális gyüjteményfejlesztési és szolgáltatásfejlesztési stratégia és gyakorlat megújitására, valamint egységes módszertan használatára. Ez utóbbihoz ad majd segitséget a KDS keretében elkészülő Fehér Könyv ${ }^{6}$, amely a digitalizálás teljes munkafolyamatához nyújt módszertani útmutatót a közgyüjtemények számára.

A KDS szolgáltatási modellje háromszintü. Az első a primér szint, az intézmények szintje, ahol a tartalomelöállítás történik, a második, az ágazati aggregátorok szintje, ahol begyüjtik az intézményektöl a tartalmakat, összefésülik, adatgazdagitják, és így továbbítják a Nemzeti Adattár Projekt (NAP) összközgyüjteményi keresőjébe. amely a jövöben készül el.

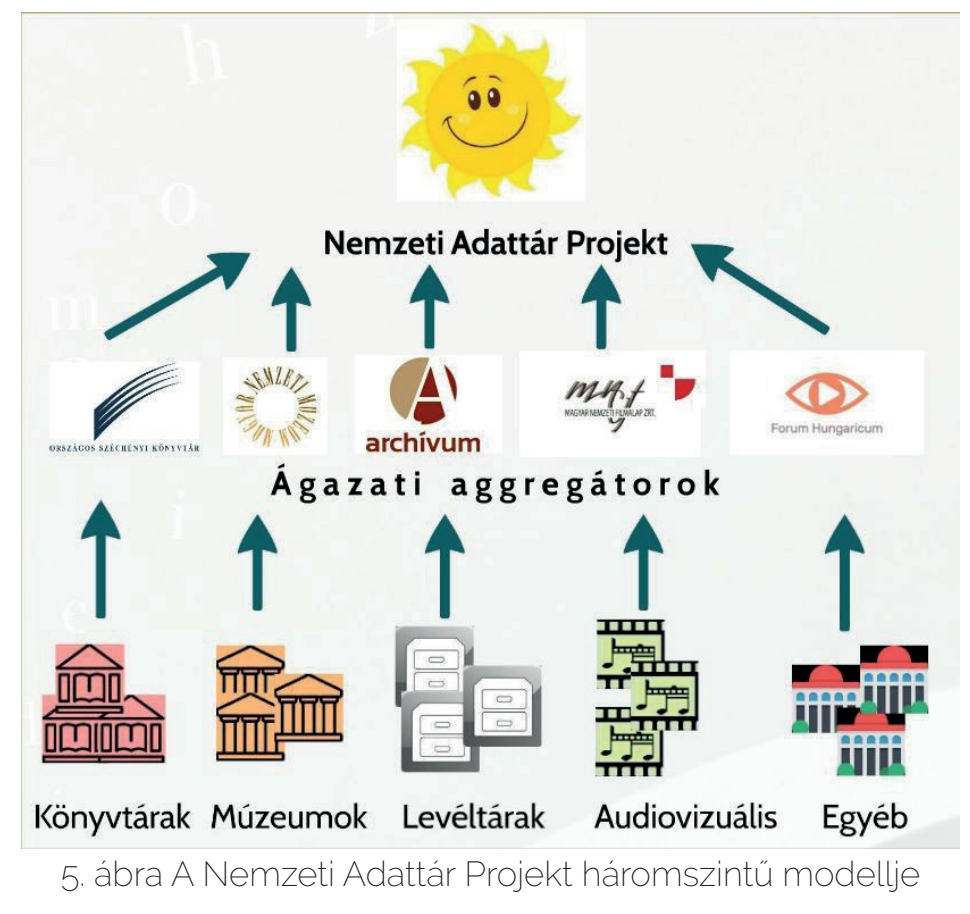

6 Az 1175/2018. (III.28.) Korm.hat.3.pontjában a Nemzeti Adattár Projekt megvalósitása érdekében kidolgozott módszertani segédlet 
A múzeumi terület központi intézménye a Magyar Nemzeti Múzeum, amely már 2015-ben elinditotta ágazati aggregációs szolgáltatását. A szolgáltatás müködési modellje az Europeana, mint az európai szintü aggregáció müködési modelljének hazai adaptációja. A tartalomszolgáltatók háromféleképpen juttathatják el a rekordjaikat a MuseuMap számára: intézményi adatbázisokból, OnlineData webes alapú beviteli rendszerböl vagy országos múzeumokon keresztül. Az aggregáció harvesztálási sémája a múzeumi területen nemzetközileg is elterjedt LIDO formátum, de a MuseuMap bármilyen rendszerböl képes szabványos formában átadott rekordokat fogadni. A múzeumi aggregációs szolgáltatás publikus felülete a MuseuMap portál (www.museumap.hu), ahol jelenleg 30 múzeum több mint 300 ezer rekordja között böngészhet a látogató.

A KDS keretében 2019-ben inditott hároméves Mintaprojektnek legföbb célkitüzése, hogy a múzeumoknál jó minőségü, a felhasználói igényeket széles körüen kielégítő digitális tartalmak készüljenek, amelyek az aggregátori szolgáltatásokban továbbhasznosulhatnak.

\subsection{Minöségi digitális objektumok}

A magas színvonalú közzétételi szolgáltatásokhoz korszerü technológiával elöállított mesterfájlok szükségesek, amelyekböl további felhasználásra alkalmas, élményszerü szolgáltatási példányokat lehet generálni. A digitális objektumok közzétételi elvárásaira vonatkozóan a Fehér Könyv az Europeana Publikációs Keretrendszer Digitális tartalmakra vonatkozó útmutatóját ajánlja, amely minden médiatipusra négy közzétételi szintet határoz meg, és ezekhez paramétereket rendel Az első szint, amikor a tartalmainkkal csak a keresőmotorokat szeretnénk kiszolgálni, a második szint, amikor már alkalmasak a tartalmak tematikus gyüjtemények vagy virtuális kiállitások létrehozására, a harmadik és a negyedik szint pedig a kreatív, nem kereskedelmi (pl. oktatási célú) és kereskedelmi célú (pl. kreativ ipar) újrafelhasználási igényeit írja le. Az utóbbi két esetben a jogi szabályozásban vannak különbségek.

Képfájlok esetében:

- 1., 0,1 megapixel, 400 pixel széles előnézeti kép - (keresőmotorok)

- 2., 0,5 megapixel kb. 800 pixel széles képfájl (tematikus gyüjtemények, virtuális kiállítások)

- 3., Minimum1200+ pixelszélesajánlott (nemkereskedelmi célú újrafelhasználás; pl. oktatás)

- 4., Minimum 1200+ pixel széles ajánlott (kereskedelmi célú újrafelhasználás, kreativ ipar)

\subsection{Minőségi leíró adatok}

A digitális objektumokhoz füzött, szöveges információk egyik részét a mütárgy metaadatai jelentik. Az informatív tárgyleíráshoz elengedhetetlen, hogy a nyilvántartási rendelet mezöiböl minél többet, minél részletesebben adjanak

7 Europeana Publishing Framework. Hozzáférés: 2019.06.30.

https://pro.europeana.eu/post/publishing-framework 
meg a muzeológusok. Másrészt az újrafelhasználás szempontjából fontos, hogy megszülessenek azok a felhasználói igényekhez alakitott narrativ leirást tartalmazó részek, amelyek további kontextusba helyezik a mütárgyakat és megkönnyitik a befogadást. Márintézményiszintenelindulhatnasajátvagykülsönévterekhasználata az adatbázisban rögzitett entitások (személy, hely, fogalom stb.) beazonositására. A strukturált formában tárolt, karbantartott adatok eredményesebben hasznosulnak további, közös szolgáltatásokban is.

\subsection{Adatgazdagítás}

A digitális rekordok plusz információval való ellátását a KDS az aggregátorok szintjére helyezi át. A múzeumi ágazat aggregátor intézménye a Magyar Nemzeti Múzeum ${ }^{8}$, amelynek feladata, hogy az intézmények rekordjait begyüjtse, egységesitse, további információkkal gazdagitsa, és igy továbbitsa a tartalmakat a NAP keresörendszerébe.

Az adatgazdagitást tekintve a múzeumi terület is a klasszikus értelemben vett négy dimenziójú adatgazdagitást veszi alapul: a személyre, helyre, időre, fogalomra történő szemantikai dúsitást.

\section{Az adatgazdagitáshoz leggyakrabban használt források:}

\section{Személy}

VIAF: The Virtual International Authority File

ULAN: Union List of Artist Names

DBpedia

wikidata

Petöfi Irodalmi Múzeum személynévtere

FOAF: Friend of friend ontology

\section{Idő}

Time Ontology in OWL

Periodo

DBpedia

wikidata https://viaforg/

http://www.getty.edu/research/ tools/vocabularies/ulan/

https://wiki.dbpedia.org/

https://www.wikidata.org/

https://opac-nevter.pim.hu/

http://www.foaf-project.org/

https://www.w3.org/TR/owl-time/

http://perio.do/en/

https://wiki.dbpedia.org/

https://www.wikidata.org/

8 A Magyar Nemzeti Múzeum 2015-töl müködteti ágazati aggregációs szolgáltatását MuseuMap néven. Www. museumap.hu 
Hely

GeoNames

TGN: The Getty Thesaurus of

Geographic Names,

Pleiades

\section{Fogalom}

AAT: Art\&Architecture Thesaurus

DBpedia

wikidata

GEMET: General Multilingual

Environmental Thesaurus

Iconclass
https://Www.geonames.org/

http://www.getty.edu/research/tools/ vocabularies/tgn/index.html

https://pleiades.stoa.org/

http://www.getty.edu/research/tools/ vocabularies/aat/

https://wiki.dbpedia.org/

https://wwww.wikidata.org/

https://www.eionet.europa.eu/gemet/ en/themes/

http://www.iconclass.org/

\subsection{Kapcsolódás a Magyar Nemzeti Névtér szolgáltatáshoz}

Mivel a múzeumi nyilvántartási gyakorlatban nem hangsúlyos a besorolási állományok gondozása, például megengedett a személynevek és testületi nevek (pl. fotómühely, szerkesztőség) egy szótárban való kezelése, a Nemzeti Névtér használata komoly elörelépést jelentene a múzeumok számára, hogy a gyüjteményeikhez kapcsolódóan pontosabb és bővebb információszolgáltatást valósitsanak meg.

\section{A Nemzeti Névtér hasznositásának lehetöségei:}

- A névtér névjegyadatainak használata a helyi rendszerekben szereplö nevek egyértelmü azonositásához

- Hivatkozás a névtérre: URI-k beemelése a helyi rendszerek besorolási állományaiba

- A Nemzeti Névtérben található adatok, névrekordok honositása a helyi rendszerek besorolási állományaiba

A múzeumi szféra nemcsak felhasználóként, hanem adatszolgáltatóként is közremüködhet a Nemzeti Névtér-szolgáltatásban. Ahelynevek pontos megjelölése kiemelt fontosságú több múzeumi szakanyag esetén, ezért a régészeti, a néprajzi vagy a természettudományi gyüjtemények lelöhelyre/gyüjtőhelyre vonatkozó információi bővebb adatkörrel rendelkeznek, mint a Földrajzi Névtér névjegyadatai.

\section{Lehetöségek a múzeumi adatok szolgáltatására a Földrajzi Névtérbe:}

- A régészeti lelőhely-nyilvántartás integrálása a Nemzeti Névtérbe

- További lehetőség a Magyar Nemzeti Múzeum Régészeti adatbázisának (Ariadne) összekötése a Nemzeti Névtérrel. https://archeodatabase.hnm.hu/hu

- A Magyar Természettudományi Múzeumban épitett gyüjtőhely-listák integrálása a Nemzeti Névtérbe

9 Régészeti adatbázis. Hozzáférés: 2019.06.30. https://archeodatabase.hnm.hu/hu 
Amennyiben a szakági aggregátorok egységesen alkalmazzák a Nemzeti Névtérazonositókat, lehetővé válik, hogy a heterogén állományok ellenére kapcsolatok épüljenek fel a különböző közgyüjteményekben található entitások között, az így létrejövő szemantikus háló segitségével pedig további ráépülö, interdiszciplináris szolgáltatások valósulhatnak meg.

\subsection{Oktatási célú adatgazdagítás}

A KDS szempontjából kiemelt fontosságú a közgyüjteményekben keletkező digitális tartalmak újrahasznositása az oktatás területén. A köznevelésben résztvevők számára a kereshetőséget és a hozzáférést a leiró adatok bővitése biztositaná a köznevelés tartalmi szabályozóinak fogalomkészlete alapján. A kategóriaképzés elve az altémák szerinti csoportositás, a nevelés szakaszaihoz és a tartalmi szabályozókhoz (Nemzeti alaptanterv, kerettanterv) való hozzárendelés. A fogalomkészlet megadását a múzeumi terület is az oktatási szereplőktől várja.

\section{Új technológia alkalmazása}

A digitális átállás egyik következménye, hogy a múzeumi területen is egyre nagyobb számú adat keletkezik, aminek a kezeléséhez nem áll rendelkezésre elég szakember. Az újonnan keletkező tartalmak mellett folyamatos feladat a már meglévő állományok gondozása is. A tartalmak gyorsabb és hatékonyabb feldolgozására a mesterséges intelligencia bevonása jelent megoldást. A múzeumi adatbázisokban található rekordok digitális objektumait (médiatartalom) és a hozzájuk tartozó szöveges információkat elemezhetjük tanuló algoritmusok segítségével, külső források (szótárak, tezauruszok, névterek) figyelembevételével. A tartalomalapú elemzésbe beletartozhat: az arcfelismerés, szinelemzés, formák, helyszínek, korok vagy stílusirányzatok felismertetése. Az új technológia előnye, hogy a sokkal több időt igénylő manuális munkavégzést kiváltva gyorsabb és eredményesebb lehet a tartalmak feldolgozása, valamint a gépi intelligencia addig nem ismert kontextusokat is feltárhat a mütárgyak között.

A hazai múzeum szakma tehát jelentős változások előtt áll, amennyiben a KDS-ben megfogalmazott szolgáltatási igényeket figyelembe kivánja venni. A digitalizálási gyakorlat szemléletének megújítása és a korszerü technológia integrálása egyaránt segithet, hogy a múzeumi ágazat hatékonyabban járuljon hozzá a kultúra átörökitéséhez és a digitális kulturális örökség társadalmi hasznosulásához. 


\title{
A nyilt hozzáférés kérdése a hivatalos statisztikában Some Aspects of Open Access and Official Statistics
}

\author{
Lencsés Ákos \\ ORCID: 0000-0003-4461-1105 \\ MTA Könyvtár és Információs Központ EISZ Titkárság (grid.496758.1) \\ ELTE BTK Könyvtár- és Információtudományi Intézet \\ Könyvtártudományi Doktori Program (grid.5591.8)
}

The past decades have revealed the importance and want of Open Access in the academic sphere. The recent steps, e.g. Plan S show that research funds are all aware of Open Access and are ready to step forward to a fully OA world. The study focuses on how OA appears in the landscape of official statistics - while academic sphere is not the main focus in this field, still official statistics is relevant for the academics in many ways.

The study analyses the publications - books, yearbooks, journals - of European official statistics regarding their availability. With a few exceptions, national statistical offices are all committed to OA. There are future challenges for official statistics as metadata and other tools that help to integrate official yearbooks and other publications into the research workflow are poorly represented.

Keywords: statistical yearbook, open access, official statistics, statistical dissemination

\section{Bevezetés}

A tudományos világban az elmúlt évtizedekben egyre nagyobb hangsúly kapott a nyilt hozzáférés kérdése. A legújabb fejlemények, pl. a Plan S létrejötte azt mutatják, hogy a kutatásfinanszírozó testületek a jövőt a teljes körü nyiltt hozzáférés jegyében képzelik el. Érdemes megvizsgálni, hogy más - a kutatás szempontjából releváns, de nem elsősorban kutatási anyagokat előállító - területeken hogyan jelenik meg a nyiltt hozzáférés kérdése.

Az elöadás a hivatalos statisztika évkönyveit és folyóiratait vizsgálja, elsősorban a nyilt hozzáférés szempontjából. A 2017 első félévében végrehajtott felmérés segit megállapitani, hogy a hivatalos statisztikai intézmények mennyire elkötelezettek a nyiltt hozzáférés irányába. A vizsgálat óta természetesen több esetben történt változás, így például a Statisztikai Szemle is nyilt hozzáférésü folyóirattá vált. Jelen írásban a 2017 első félévének megfelelő állapotokat vizsgáljuk.

\section{Statisztikai évkönyvek Európában}

Valamennyi nemzeti statisztikai hivatal számára a statisztikai évkönyv a leginkább reprezentatív kiadvány. Az évkönyvek vizsgálatából több következtetés is levonható a hivatalok müködésére vonatkozóan. ${ }^{1}$ Az alábbi felmérésben az európai országok gyakorlatát mutatjuk be a statisztikai évkönyv szabad hozzáférhetöségére

1 Lencsés Ákos. „A Magyar statisztikai évkönyv szerkezetének változásai 1872 és 2016 között." Statisztikai Szemle 95, 11-12. sz. (2017): 1144-1158. DOl: 10.20311/stat2017.11-12.hu1144 
vonatkozóan. Az adatgyüjtés során nem vettük figyelembe a statisztikai zsebkönyveket, kizárólag az egyes országok átfogó statisztikai évkönyvére koncentráltunk. Így nem okoz torzitást a vizsgálatban, ha az ország statisztikai zsebkönyve vagy más rövid, statisztikai jellegü ismertetést tartalmazó kiadványa nyilt hozzáféréssel elérhető, az átfogó statisztikai évkönyvazonban csak embargóval tekinthetö meg.

Több országot kizártunk a vizsgálatból. Ennek oka méretük vagy az, hogy a közelmúlt politikai változásai miatt nem értelmezhető még relevánsan a hivatali intézményrendszer minden irányvonala. Ennek megfelelően a torzitások kiküszöbölése érdekében nem tartalmazza a táblázat Andorra, BoszniaHercegovina, Ciprus, Koszovó, Liechtenstein, Luxemburg, Macedónia, Málta, Moldova, Monaco, Montenegró, San Marino, Szerbia, Ukrajna és Vatikán adatait. A felmérésben így Albánia, Ausztria, Belgium, Bulgária, Csehország, Dánia, Észtország, Fehéroroszország, Finnország, Franciaország, Görögország, Hollandia, Horvátország, Írország, Izland, Lengyelország, Lettország, Litvánia, Magyarország, Nagy-Britannia, Németország, Norvégia, Olaszország, Oroszország, Portugália, Románia, Spanyolország, Svájc, Svédország, Szlovákia és Szlovénia kiadványai szerepelnek. Az adatok forrása minden esetben az ország nemzeti statisztikai hivatalának honlapja volt. Az adatgyüjtés során nagy segítséget jelentett a Központi Statisztikai Hivatal Könyvtár által üzemeltetett Digistat adatbázis. ${ }^{2}$

A felmérésben az alábbi kérdéseket vizsgáltuk:

- megjelenik-e nyomtatásban az ország statisztikai évkönyve;

- megjelenik-e online az ország statisztikai évkönyve;

- az online változat nyiltt hozzáférésü-e;

- elérhetö-e a kiadványok archivuma;

- mennyi a nyomtatott kiadványok listaára.

Az adatok alapján kijelenthető, hogy a statisztikai hivatalok túlnyomó része elkötelezett a nyiltt hozzáférés irányában. Ugyanakkor az intézmények nagy része fontosnak tartja a nyiltt hozzáférésü online kiadványok mellett a nyomtatott évkönyvek megjelentetését is. A nyomtatott kiadványok ára nagy változatosságot mutat, és nem minden esetben mondható el, hogy a nyugat-európai országok statisztikai évkönyvei drágábbak lennének a kelet-európai hivatalok kiadványainál.

A vizsgálatban szereplő 31 ország közül 21 megjelenteti nyomtatásban is az átfogó statisztikai évkönyvet. A többi 10 ország egy része átfogó statisztikai évkönyvet nem jelentet meg, de kisebb terjedelmü, gyakran ismeretterjesztő kiadványt nyomtatásban is közread. A nyomtatott évkönyveket megszüntető hivatalok általában az évkönyvek szerkesztését is megszüntették. Egyetlen kivétel Írország, ahol továbbra is elöállitják a kötet formájára tördelt PDF-változatot a statisztikai évkönyvböl, azonban nyomtatásban már nem jelentetik meg. A nyomtatott változatot (illetve általában a statisztikai évkönyvet) elsöként Franciaországban és Nagy-Britanniában szüntették meg, 2005-ben. Ennek oka valószínüleg

2 Digistat. http://konyvtar.ksh.hu/index.php?s=db_digistat [2019. június 20.] 
nemcsak az informatikai fejlődés, hanem a két ország intézménystruktúrájának sajátossága. Mindkét országban több hivatal foglalkozik a statisztika elöállitásával és publikálásával, és ezek az intézmények gyakran önállóan jelentették, illetve jelentetik meg kiadványaikat. ${ }^{3} A z$ észak-európai országok elsőként döntöttek úgy, hogy az adatok közreadását egyáltalán nem kötik kiadványokhoz. A 2010es években megszüntek a norvég és a svéd statisztikai évkönyvek. Ez a változás azonban már nem az intézményi környezetnek köszönhetö, hanem tudatos döntés a kiadványstruktúra leépítése mellett az online, adatbázisokban történő megjelenítés javára. Hasonló fejlődést járt be a belga és a holland statisztikai hivatal kiadványpolitikája is.

Írország statisztikai hivatala egyetlen intézményként kizárólag online teszi közzé az évkönyvet. Svájc pedig egyetlen országként kizárólag nyomtatásban forgalmazza a statisztikai évkönyvet - nem teszi lehetövé a PDF-ben történő letöltést vagy megvásárlást sem. Mindössze négy olyan hivatalt találtunk, amely a létező online változatot nem teszi szabadon hozzáférhetővé. Három esetben (Magyarország, Szlovákia, Románia) nyolc-tizenkét hónapos embargóval lehet szabadon elérni a kiadványokat, de természetesen megvásárolható a hozzáférés az embargó időszakában is. Svájc az egyetlen ország, amely se szabadon hozzáférhető, se fizetős módon nem biztosit hozzáférést a statisztikai évkönyv online változatához. A vizsgált országok közül19 ország teszia megjelenés idejében nyiltan hozzáférhetővé a statisztikai évkönyvet, tehát az európai statisztikai hivatalok túlnyomó része elkötelezett a nyilt hozzáférés iránt.

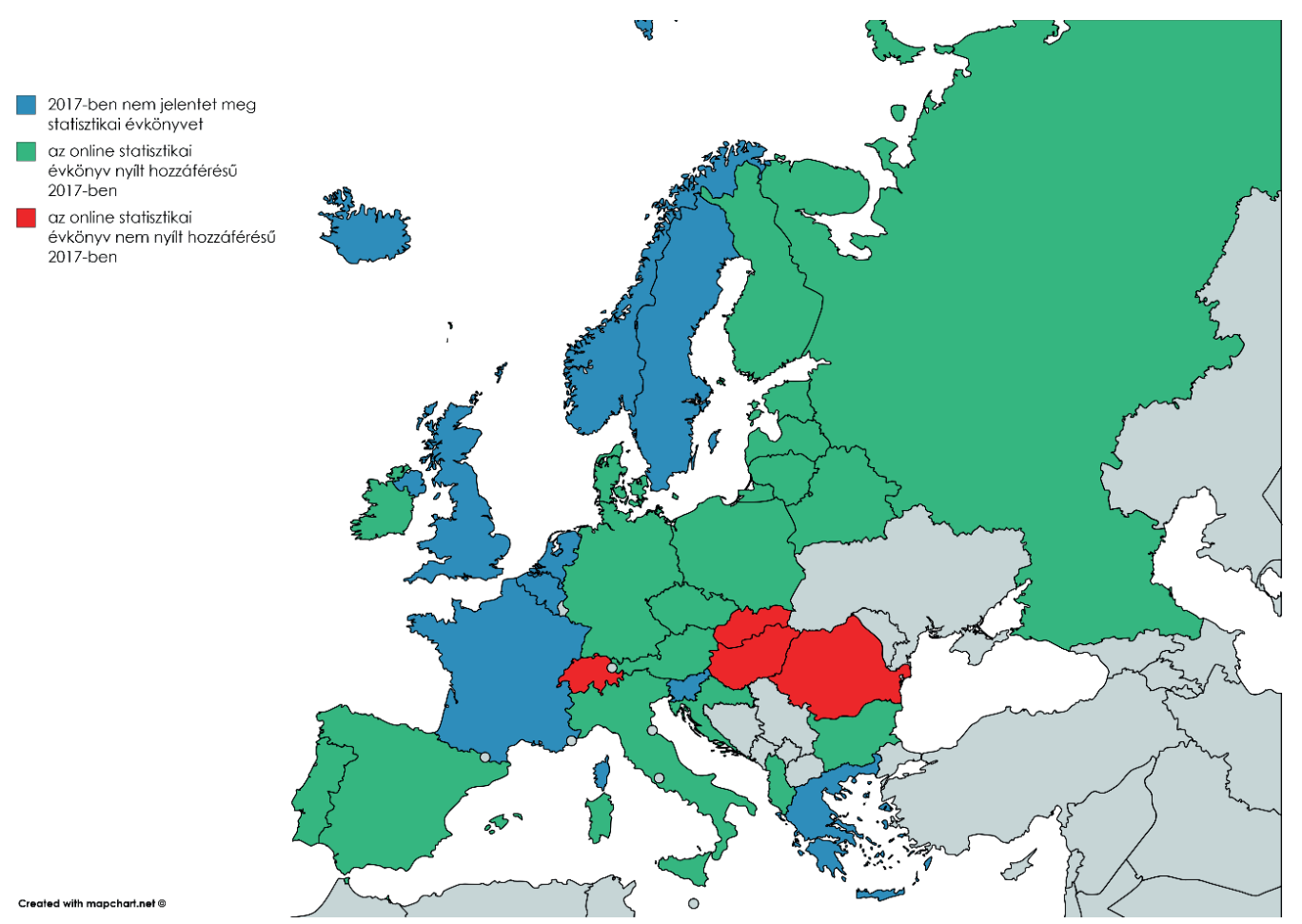

1. ábra A statisztikai évkönyvek és a nyilt hozzáférés helyzete Európában

3 Rózsa Dávid, Kalmár Csilla, Lencsés Ákos. „A statisztika és a digitális átállás." = Tudományos és Müszaki Tájékoztatás 60, 2. sz. (2013): 47-65 
Az archív statisztikai évkönyveket mindössze négy hivatal nem teszi hozzáférhetövé (Albánia, Ausztria, Franciaország, Izland). Ez az arány elsőre jónak nevezhető. Azonban mindössze 6 olyan hivatalt sikerült azonositani, amely hangsúlyt fektet arra, hogy a statisztikai évkönyvek digitális korszakot megelöző példányai is online hozzáférhetök legyenek (Norvégia, Svájc, Lettország, Görögország, Németország, Szlovénia). Természetesen a hat ország mellett egyes további országokban is elérhető az archiv tartalom, de nem a hivatal saját felületén. A statisztikai hivatalok túlnyomó többsége nem áldoz eröforrást arra, hogy a digitális világ elötti kiadványok online elérhetök legyenek. 17 esetben csak az 1990-es vagy 2000-es évektöl hozzáférhetök az eleve digitálisan létrejött kiadványok. 4 további esetben is csak az elmúlt 30 esztendő dokumentumai érhetők el.

Érdekes a hivatalok egy részének nyomtatott kiadványokhoz való ragaszkodása annak fényében, hogy egyes szerzők már a kétezres évek elején a nyomtatott statisztikai kötetek eltünését jósolták. ${ }^{4}$ Megmaradásuk oka talán nem is praktikusságukban, hanem reprezentativ szerepükben rejlik. A német statisztikai hivatal egyik felmérésében a statisztikai adatokat rendszeresen felhasználók 85\%a ismerte az átfogó statisztikai évkönyvet, de csak 8\%-uk az ágazati kiadványokat. ${ }^{5}$

Vizsgáltuk a nyomtatott statisztikai évkönyvek árát is. Az összehasonlithatóság érdekében a Magyar Nemzeti Bank 2017. évi középárfolyamával számolva próbáltunk durva becslésre alkalmas árakat elöállitani. 18 évkönyv esetén sikerült a hivatal által meghatározott fogyasztói árat azonositani. Az évkönyvek átváltás utáni becsült ára 19 és 120 euró között változik. Legolcsóbb a cseh és az észt (19 és 20 euró), legdrágább a svájci (120 euró) statisztikai évkönyv. Az árakat vizsgálva nem érződik a nyugati és északi országok gazdasági dominanciája: a lengyel és a német egyaránt 71 euróba kerül, az olcsóbb kötetek között megtaláljuk a spanyol vagy a portugál statisztikai évkönyvet is. A magyar statisztikai évkönyv a vizsgált kötetek közül a harmadik legolcsóbb kiadvány, csak az észt és a cseh évkönyv olcsóbb nála.

Külön kategóriát képvisel az egyes európai statisztikai évkönyvek közül az Eurostat statisztikai évkönyve (Europe in Figures). Ennek utolsó nyomtatásban megjelent tárgyéve 2012. ${ }^{6}$ Azóta a kiadvány online módon érhető el, azonban nem egyszerre megjelenő, változásmentes kiadványról van szó. Az adatok folyamatos változása és frissitése inkább adatbázisra vagy a Wikipédiára emlékeztetö felületet eredményez. Könyvészeti szempontból a megoldás nehezen értelmezhető monográfiaként vagy évkönyvként - bár az oldal nevében még őrzi a yearbook kifejezést.

Afentivizsgálatalapjánkijelenthető, hogynincsegységesgyakorlatazegyesországok statisztikai hivatalai részéröl az átfogó statisztikai évkönyvek megjelentetésére. A

$4 \quad$ Cannon, San, Marc Rodriguez. "Survey of On-line Data Dissemination Practices for Government and International Statistics." The Statistics Newsletter 49. Sz. (2010): 5-8

$5 \quad$ Pfeiffer, Annette „Das Image des Statistischen Bundesamtes." Wirtschaft und Statistik 12. sz. (2001): 981-987.

6 Rózsa Dávid, Kalmár Csilla, Lencsés Ákos. „A statisztika és a digitális átállás." = Tudományos és Müszaki Tájékoztatás 60, 2. sz. (2013): 47-65 
megoldások sokfélék a kiadványalapú adatközlés elhagyásától, a kizárólag online formátumban való megjelentetésen át, a hagyományos nyomtatott kiadványokon keresztül a fizetős és nyilt hozzáférésü online kiadványokig. Európában érezhető az észak- és nyugat-európai statisztikai hivatalok elkötelezettsége a nyilt hozzáférés felé, ami gyakran párosul azzal, hogy elhagyják a kiadványalapú adatközlést.

\section{A hivatalos statisztika folyóiratai}

A vizsgálat folytatásaként a statisztikai évkönyvek mellett az egyes hivatalok által megjelentetett folyóiratok nyilt hozzáférését mértük fel. A vizsgálatnak a statisztikai hivatalok nyiltt hozzáférés felé való elkötelezettségének megállapítása volt a célja, nem pedig általánosságban a statisztikai folyóiratok nyílt hozzáférésének felmérése. Így a tudományos kiadók vagy nem hivatalos szakmai szervezetek által kiadott folyóiratok nem kerültek az összegzésbe. A vizsgálatba ezért azokat a folyóiratokat vontuk be, amelyeket a statisztikai hivatalok önállóan jelentetnek meg. Nem kerültek be az elemzésbe a szakkiadók vagy szakmai szervezetek által megjelentetett kiadványok, így például az osztrák statisztikai társaság által kiadott Austrian Journal of Statistics vagy a Wiley kiadó által megjelentetett brit Royal Statistical Society folyóiratcsaládja. Ezeket a folyóiratokat abban az esetben sem vontuk be a vizsgálati körbe, ha nyilt hozzáféréssel elérhetök, így a svéd statisztikai hivatalnak a De Gruyter kiadó gondozásában megjelenö Journal of Official Statistics folyóirata sem szerepel a kutatásban. Bekerültek a vizsgálatba azonban a statisztikai hivatal és állami egyetemek, kutatóintézetek közös kiadásában megjelenő folyóiratok, például a cseh statisztikai hivatal és a cseh közgazdaság-tudományi egyetem által együtt jegyzett Statistika folyóirat.

A felmérésbe végül tíz ország tizennégy folyóriatát vontuk be: Ausztria (Statistische Nachrichten), Bulgária (Statistika), Csehország (Demografie; Statistika), Franciaország (Population; Économie et Statistique), Lengyelország (Wiadomości Statystyczne), Magyarország (Statisztikai Szemle; Demográfia; Területi Statisztika), Németország (Wirtschaft und Statistik), Portugália (Revstat), Románia (Romanian Statistical Review), Szlovákia (Slovenská Štatistika a Demografia). A kutatásban a 2017. elsö negyedév szerinti állapotnak megfelelően vizsgáltuk a folyóiratok nyelvét, periodicitását, nyiltt hozzáférését és az archiv számok elérhetőségét.

A hivatalok által megjelentetett folyóiratok jelentős része nemzeti nyelven jelenik meg, nem elhanyagolható azonban az angolul megjelenö címek száma sem. Általában azok a folyóiratok tartoznak ez utóbbiak közé, amelyeket egy-egy statisztikai hivatal valamelyik felsőoktatási intézménnyel vagy kutatóintézettel közösen jelentet meg. Így a cseh statisztikai hivatal és a cseh közgazdaságtudományi egyetem Statistika folyóirata kizárólag angolul jelenik meg, a francia Population pedig egyedi módon francia és angol kiadásban is elérhető.

Az európai hivatalos statisztika intézményei által kiadott folyóiratok túlnyomó része nyiltt hozzáféréssel megtalálható az interneten. A vizsgált címek közül egyedül a Statisztikai Szemle, a Population és a Statistische Nachrichten nem érhetö el nyilt hozzáféréssel. Ez utóbbi különösen meglepő, mivel az osztrák statisztikai évkönyv 
embargó nélkül elérhető a hivatal honlapján. Bár a vizsgálat szempontjai között nem szerepelt, de valamennyi folyóirat megjelenik nyomtatásban is. Franciaországot leszámitva minden szakfolyóiratot megjelentető európai statisztikai hivatal a statisztikai évkönyvet is megjelenteti nyomtatásban. Ugyanakkor az évkönyvet nyomtatásban nem megjelentető hivatalok általában online megjelenő folyóiratot sem üzemeltetnek.

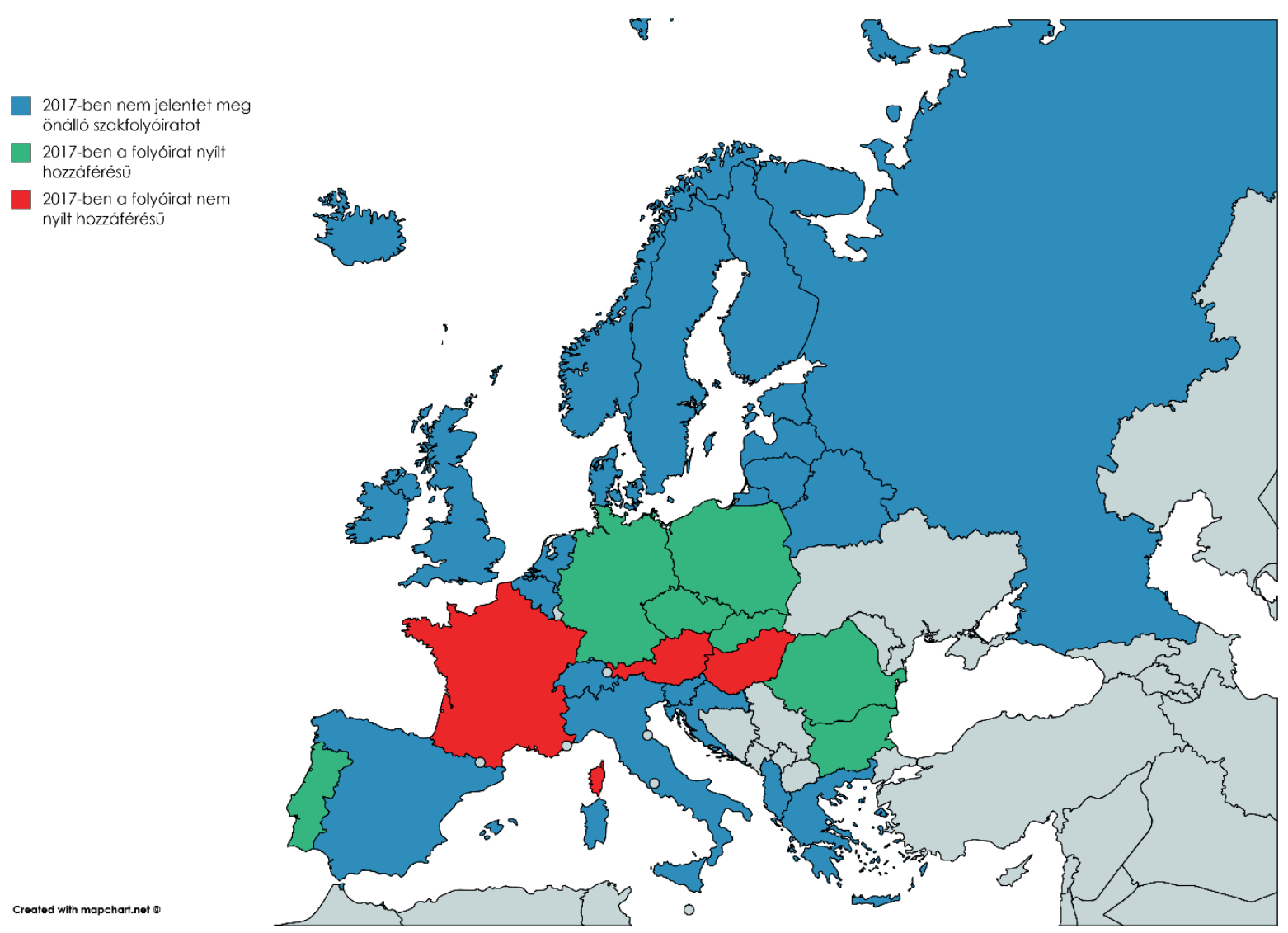

2. ábra A hivatalos statisztika folyóiratai és a nyilt hozzáférés helyzete Európában

Az archiv számok az évkönyvekhez hasonlóan általában az online változat megjelenésétöl érhetők el. A korábbi nyomtatott évfolyamok digitalizálása és közzététele általában egy-egy kerek évfordulóhoz köthetően jelenik meg, mint a Statisztikai Szemle kilencvenedik évfolyama vagy az Économie et Statistique elődfolyóiratának számító La Conjoncture első megjelenésének hetvenedik évfordulója.

A KSH gondozásában megjelenő gazdag folyóirat-portfólió nem jellemző a külföldi statisztikai hivatalokra. Ugyanakkor más országokban gyakrabban fordul elö, hogy a hivatalos statisztikai szolgálat szervezetei mellett egyesületek, tudományos társaságok kiadványai gazdagitják a statisztikai szakirodalmat, és így egymás mellett és egymást kiegészitve jelennek meg a statisztikai hivatal és az attól független statisztikai szervezetek folyóiratai. 
A folyóiratok periodicitása meglehetöségen nagy változatosságot mutat, de a lehető legritkább esetben jelennek meg havonta. A Statisztikai Szemle mellett kizárólag a Statistische Nachricten és a Wiadomości Statystyczne jelentkezik minden hónapban. A KSH folyóiratai között is kizárólag a Statisztikai Szemle rendelkezik havi periodicitással, a Területi Statisztika és a Demográfia kéthavonta, illetve negyedévente jelenik meg. Általánosságban a kéthónapos mellett inkább a negyedéves megjelenés jellemző a statisztikai hivatalok folyóirataira. A nemzeti nyelven megjelenő periodikák szinte mindegyike megjelentet angol nyelvü különszámot is éves vagy kétéves gyakorisággal.

A hivatalos statisztika folyóiratai általában nem rendelkeznek impakt faktorral - és ez alól nem jelentenek kivételt az angol nyelvü lapok sem. Az impakt faktor értékeket nyilvántartó és szolgáltató Clarivate Analytics adatbázisai szerint (Journal Citation Report, Web of Science) 2017-ben összesen 123 statisztikai folyóirat rendelkezett impakt faktorral. Ezek a kiadványok kivétel nélkül tudományos társaságok és profi szakkiadók termékei. Mindössze két folyóirat rendelkezik impakt faktorral a hivatalos szervezetek lapjai közül. Ezeket azonban nagy, nemzetközi kiadók jelentetik meg a hivatallal együttmüködve: a kanadai statisztikai hivatal Survey Methodology és a svéd hivatal Journal of Official Statistics folyóirata. Ez a jelenség is rávilágit arra, hogy a hivatalos statisztika szervezetei kiadványaikat nem kizárólag a tudományos közösség számára jelentetik meg - legalábbis nem szorulnak rá, hogy részt vegyenek olyan versenyhelyzetekben, amelyeket a kiadói folyóiratokra kényszeritenek a tudománymetriai mutatószámok.

\section{Összegzés}

A felmérés adatai alapján megállapitható, hogy a hivatalos statisztika intézményei nagyrészt elkötelezettek a nyiltt hozzáférés irányába. Ugyanakkor érdekes, hogy a statisztikai évkönyvek és a szakfolyóiratok más mintázatot mutatnak a nyiltt hozzáférés szempontjából: találni olyan intézményt, ahol az évkönyv szabadon elérhetö, a szakfolyóirat azonban nem.

A vizsgálat alapján érdemes volna a hivatalos intézményrendszerben jobban tudatosítani a nyiltt hozzáférés kérdését, hogy az intézmények egységes, a széles nagyközönségésa szakmai közösségekszámára is egyértelmüirányvonalakmentén képviseljék a nyiltt hozzáférés gyakorlatát - és természetesen csatlakozzanak a mozgalomhoz azok az intézmények is, amelyek egyelöre csak fizetös módon biztositják egyes online kiadványok hozzáférését.

\section{Irodalomjegyzék}

1. Cannon, San, Marc Rodriguez. „Survey of On-line Data Dissemination Practices for Government and International Statistics." The Statistics Newsletter 49. sz. (2010): 5-8.

2. Lencsés Ákos. „A Magyar statisztikai évkönyv szerkezetének változásai 1872 és 2016 között." Statisztikai Szemle 95, 11-12. sz. (2017): 1144-1158. DOI: 10.20311/ stat2017.11-12.hu1144 
3. Pfeiffer, Annette "Das Image des Statistischen Bundesamtes." Wirtschaft und Statistik 12. Sz. (2001): 981-987.

4. Rózsa Dávid, Kalmár Csilla, Lencsés Ákos. „A statisztika és a digitális átállás." Tudományos és Müszaki Tájékoztatás 60, 2. sz. (2013): 47-65. 


\title{
Entitások és kapcsolódások a könyvtári rendszerekben és azokon túl
}

\author{
Lendvay Miklós \\ Országos Széchényi Könyvtár, Információtechnológiai lgazgatóság \\ lendvay.miklos@oszk.hu \\ ORCID: 0000-0001-8065-5282
}

The limitations of time and physical space required in the workflows of cooperation and provided services seems to vanish as a result of the data and information revolution brought about by IT technology. The entity-based approach in the library sector means that we split all major components of the interlinkages into small units: the data elements become interlinked atomic descriptions; the units of connection may be institutions or individual scientists, the flexibility is limitless; the software components are small modules, microservices. The National Library Platform will be a distributed cooperation tool. This open source, cloud-based platform will go live in 2020, and it will be available for any type of library. Currently we have completed three modules of the platform: the National Namespace, a flexible cataloging tool, and an integrated text search - all these software-components break down the data into entities.

Keywords: entity, new generation library platform, namespace

Az információs technológia és a kiszolgáló IT megoldások fejlődésével a világról szóló legszélesebb körü, legkülönfélébb tematikájú és legváltozatosabb metaadatstruktúrájú információk összekötése vált lehetővé felhőalapú megoldásokkal, szemantikus hálóban. A világháló képes áttörni a témakörök, az intézmények és a szakirányok, a nyelvek és a kódrendszerek korlátait. A hagyományos szerkesztésü, ellenörzött és engedélyezett publikációval ellentétben a világháló egyáltalán nem a szakirányi meghatározottságból, hanem az információ sokkal kisebb egységeiből építkezik. Nem a nagy ívet bontja le apróbb egységekre, hanem az apró mozaikokból késziti összetett építményeit.

Az utóbbi évtizedekben hagyományos könyvtári világot alapvetően átalakitó információs technológiák jöttek létre. Az egyre fejlődő, mesterséges intelligenciával bővülő új technológia lehetővé teszi, hogy a könyvtári állományok rendszerezése során egy magasabb szintü hierarchia jelenjen meg a gyüjtemény elemeinek leírásában. A mü, annak változatai, példányai és az ezekhez kapcsolódó releváns feldolgozások és információk egyértelmüen azonositottan és értelemszerüen kapcsolhatók össze - létrehozva ezzel az értelemszerü, azaz szemantikus hálót a megbízható, ellenörzött adatok tartományában is - kiküszöbölve a szabad világháló esetlegességének és ellenörizetlenségének hátrányait.

A könyvtárak akkor képesek az informatika által adott lehetőséghez kapcsolódni, amikor ezen alapelvek alapján létrejön egy széleskörüen használt együttmüködési megosztott platform és a könyvtárak képesekké válnak a leirások, a metaadatok struktúráját a fentiek szerint használni. A meglévő adatok konszolidálása, az új adatok 
célzott és megosztott katalogizálása az együttmüködés és munkamegosztás révén a célja a könyvtárak által létrehozandó Országos Könyvtári Platformnak. Ebben az írásban részeredményekröl számolok be a Nemzeti Névtér, az integrált szövegkereső és a flexibilisen paraméterezhető katalogizáló felületünk kapcsán. Ezek a megvalósult fejlesztések az entitások kapcsolódását részben automatikusan, részben könyvtárosi munkával lehetővé tevő modulok, amelyek messze túlmutatnak a könyvtári világ határain, és más intézmények és tudományágak bekapcsolódását is lehetövé teszik - integrálják más intézményeket és az intézményeken kivüli szereplőket egyaránt.

Az entitásokat sokan és sokféleképpen értelmezik, habitus, nézőpont és egyes nyelvek / népek gondolkodásmódja szerint. Ebben az írásban az entitást önálló, zárt egységként definiálom, amely képes önállóan müködni, és az öt körülvevő entitásokkal összekapcsolódni. Mindehhez az összes kapcsolódás, esemény, az entitás teljes környezete hozzátartozik, és meghatározó abban a kérdésben, hogy mennyire van az entitás értelmezhetö, értelmes, hasznos kapcsolatban az öt körülvevő világgal, a vele kapcsolódó többi egységgel, entitással. Az entitás fogalma egyszerre foglal magába olyan különböző tárgyakat, mint dolgok, tulajdonságok, relációk, viszonyok, kapcsolódások és események. Az entitás ennél lecsupaszitottabban, szükebben és egyszerübben nem értelmezhető, létét a definíciója értelmében maga a kommunikáció, a szimbiózis, az együttmüködés adja.

A könyvtári rendszereket szemlélve entitásnak nevezhetjük a könyvtári publikációs egységeket, az információ tagolt elemeit, a könyvtári folyamatok résztvevöit, intézményeket, szereplöket, könyvtárosokat és olvasókat egyaránt. Önállóan, elszigetelten értelmét veszti mindegyik, nem képesek kiteljesedni. Ha a kapcsolódások kötöttek, meghatározottak, akkor távolabbi vagy újszerü elemek nehezen vagy egyáltalán nem képesek értelmes módon kapcsolódni velük, zárt és kommunikációra nem képes rendszerek alakulhatnak ki. Miképpen tágitható a kapcsolódások köre, miképpen tehetö az individuális tartalom univerzális jelentőségüvé és széles körben használhatóvá és újrahasznosithatóvá?

A hagyományos könyvtár entitásai elsősorban fizikai hordozóikon léteznek. Ezek sokféleképpen szemlélhetők, a fizikai határok megrajzolásával számos entitást tekinthetünk egységnek: lehet entitás egy gyüjtemény, hagyaték, de akár a könyv gerince, egy folyóiratban szereplő idézet is. A szellemi jelentés oldaláról nézve egy újabb absztrakciós szintre kell emelkednünk: a hordozójától független jelentés, gondolat, mű válik a szellemi szempontból megragadható, leirható entitássá.

A digitális feldolgozás és tárolás egy újabb dimenziót nyit az elérés szempontjából: ebben az esetben az ember érzékszerveivel a jeleket nem az adott fizikai hordozón, hanem egy elektronikusan kódolt és dekódolt jel megjelenítő felületen (monitoron, fejhallgatóban stb.) megjelenő lenyomatát érzékeli, és alakitja át jelentéssé - az ember szellemi lényként hozzáteszi a saját értelmezését, gazdagitja, torzitja, feldolgozza azt. A különbség a hordozó szempontjából elementáris: nem kell 
fizikailag megközelitenünk a tárgyat, a sok ember általi elérhetöség kedvéért már nem kell sokszorositanunk az objektumot. Az elérés többszörözéséhez az elérési utak sokszorozása, a távoli elérés megvalósitása, az egy leképezett példány sok helyröl való elérhetővé tétele a feladat. A hozzáférés forradalma a megközelités gyökeres átalakulásából adódik. Akkora forradalmi lépés ez, mint annakidején a tömeges nyomtatás és sokszorozás kialakulása volt.

(Olyannyira más filozófia ez, hogy az internet szünet nélkül való elérhetősége már az adatcserét, és ezáltal a könyvtárban annyira megszokott adatcsere formátumokat, a géppel olvasható katalogizálási formátumban (MARC - Machine Readable Code), BIBFRAME-ben stb. is hosszabb távon feleslegessé teszi, hiszen ezek helyére a megosztás lép.)

Az egész könyvtári adathalmaz nemcsak a weben való megjelenésével, publikálásával lép a nyilvánosság elé. Maga a katalógus is a háló szerves része, webböl van. Szükségszerüen egyre kisebbek a szervesen összekapcsolódó egységek - a fizikai hordozó szerepe háttérbe szorul, a digitális feldolgozás mindenböl képes „egynemü” hordozót teremteni, a látványból képet, a térbeli élményből 3D-leképezést, a hangzatból hangfelvételt, az előadásból videofelvételt, képes az eleven tartalmakat leképezni, és a 0 és 1 kombinációiból álló kódsorok képesek ezt tárolni és szükség esetén újra jelként visszaadni. Ez a flexibilis transzformációs lehetőség és ezek átviteli sebessége felszámolja a tér és az idő korlátait, bármi bármikor elérhető, átalakitható, feldolgozható és újra visszaalakitható. Átlépjük azokat a fizikai korlátokat, amelyeket a szellemi lény, az ember a fejlödése során tapasztalatszerzésre használhatott, és belépünk egy virtuális valóságba, a "minden lehetséges” és a "minden súlytalan" birodalmába. A lélek gyakran lassabb annál, minthogy a gyors, és tértöl és időtöl független váltásokat képes legyen egészséges módon beutazni. Eljutottunk addig a határig, ahola szellemi jelenlét és az anyagtalan, szubsztanciamentes információ találkozik - és egyre jelentőségteljesebbé válik a tény, hogy a szellemi lény tanúságtétele szükséges ahhoz, hogy a szellemi tartalmak valódi jelentéssel bírjanak. Úgy is feltehetnénk az ismeretelmélet kérdését: van-e zene abban a teremben, amelyben felhangzik egy oratórium, de amelyben nincs ember, aki azt átélje? Létezik-e a könyvben leírt tartalom a papírlapon, vagy csak az olvasó szellemi újrateremtése által teremtődik újra a jelentés? De ebben az írásban ez túl messzire vezetne, így megmaradunk a szellemi tartalmak fizikai jeleinek (ha mégoly illékony elektronikus) területén.

A mai könyvtárosi kihivások egyik legjelentösebbje az adatnövekedés, amivel minden tudományterületen szemben állunk. Ma már mindenki és minden formában publikálhat és publikál is, fotókat, szövegeket, gondolatokat; könnyü akár könyveket megjelentetni, de még könnyebb elöadásokat rögziteni képben és hangban, és elérhetővé tenni a világhálón. Korábban a müvek megszületése elött végig kellett gondolni az ívet, amelyet azok bejárni kivántak, elejét, közepét, végét, és utána volt érdemes papírra, kottára vetni - ezt követelte a hordozó, a papírra vetett írás. Az informatika ebben is kitágítja a lehetöségeket, és ezzel részben be is szükíti az emberi koncentráció jelentőségét: ma a szövegszerkesztővel el lehet 
kezdeni egy fogalmazványt gondolat- és mondatfoszlányokkal, majd azokat átalakitva, kibővitve, átformálva, összekötve, átrendezve egységes írást lehet alkotni. Teljes kisérletező festői életmüveket lehet képszerkesztő programmal percek alatt szimulálni. A korábbi minőségellenőrzést végző, adott esetben inspiráló szellemi mühelyek, szerkesztőségek munkáját ma talán már fel is váltotta az internetes látogatók tetszésindexe, televíziós publikációk esetén a nézettség és eladhatóság a mérvadó. Az elöállítási költségek minimálisra csökkentek, a technikai eszközök tömeges gyártása és széles körben való elérhetősége az árak radikális csökkenéséhez vezettek a nagy tömegek számára. Egy igényes drónos koncertfelvétel professzionális minőségü élö közvetitése könnyen megfizethetővé válik akár "amatörök"-nek is. A könyvtárak számára ez azt jelenti, hogy a potenciális gyüjtőkör szinte végtelenné tágul, a szelekciót és minöségellenörzést az esetek nagy százalékában nem végzi senki sem intézményesitve, sem civil módon szerveződve.

Más megközelitésben: áradnak ránk kontrollálatlan, strukturálatlan adatok. Az adatok jelentős része gépek által generált, sok kiadványt robotok állítanak össze. A mesterséges intelligencia képes az adatáradatot struktúrába szervezni, kapcsolódásokat felderiteni - és ebben a képességében emberi segítséggel tanitható. A WIKI birodalom (WikiPedia, WikiData, WikiMedia, WikiBase) eszközt ad azon emberek kezébe, akik szeretnék a rendelkezésükre álló tudást, információkat másokkal megosztani, közösségi szerkesztéssel és minöségellenörzéssel. A mai információs robbanásban egy hatalmas strukturált web-enciklopédia és médiatár alakult ki, amelyet sokan, sok forrásból, sok nyelven építenek, egy hatalmas, erre alkalmas szoftver platformon. Lehetséges-e erre úgy tekintenünk, mint a világkönyvtár egy jelentős, talán legnagyobb méretű, struktúrájában finoman tagolt kötetére?

A könyvtárak intézményi müködési módon, nagy és képzett személyzettel, állami finanszirozással járulnak hozzá, hogy a fizikailag és digitálisan publikált könyvek, folyóiratok, fotók, plakátok, webes kulturális tartalmak stb. az olvasók számára elérhetövé váljanak. A könyvtári egységek leirása lineáris, követi a jól definiált katalóguscédulák logikáját. Zárt egység, jól definiált kapcsolódási pontokkal de rugalmatlan az újra, ahhoz, hogy zártságából kiemelhető legyen, keresési adatbázisokat kell fölébe építeni.

Két alapvetően eltérő irányból tárhatjuk fel az értelmes kapcsolódásokat az információözönben fellelhető entitások között. Egyrészt a meglévő, definiált leírásokból kialakithatunk kapcsolódásokat, amelyek segítenek az egymáshoz kapcsolódó tartalmakat csoportositani, összekötni. A müvelet során a gép az ember általi leirásokból összefüggéseket generál. Másrészt kialakithatunk egy struktúrát, amelyben az entitásokat a legautentikusabb forrásból vesszük, és a platform emberi résztvevői által hozzáépitjük az információt, gazdagitjuk az ismeretek tárházát. Eszközt adunk a képzett emberi intelligencia számára, hogy strukturált módon gazdagítsa a meglévő halmazt. 
Nincs akkora személyzete a legnagyobb könyvtárnak se, hogy képes legyen megbirkózni a rázúduló feldolgozandó információhalommal. Nincs meg a szerteágazó szaktudása a könyvtárosoknak, hogy minden területen igazán érdemi módon, kellö mélységben elvégezzék a szakmai feltárást. Ezért szükséges a szereplök körét kontrollált és szervezett módon kibőviteni: bevonni a kiadókat, a szerzőket, a szakterületek tudósait stb., hogy az általuk legjobban ismert területeken maguk legyenek képesek az adatokat feldolgozni, a munkatársaikkal megosztani, a széles közönség számára publikálni. Új generációs feldolgozó eszközre és szerkesztőségi munkafolyamatokra van szükség a könyvtári munka során.

A könyvtárak által feldolgozott publikációk összefüggéseinek feltárását a szellemi egységgel, a müvel célszerü kezdeni. Csokorba kell fognunk mindazokat a publikációkat (fordítás, illusztrált kiadás, operaváltozat, megfilmesités stb.), amely teljesen azonos az eredetivel, illetve, ha nem is azonos, de még mindig ugyanaz a mü. Felismerhető kapcsolatot kell teremtenünk azokkal a kiadványokkal, amelyek a mühöz egyértelmüen kapcsolódnak, de már egy új müvet jelentenek: a müröl szóló értekezés, ismertető, paródia, recenzió, kritika, kommentár stb. A könyvtári világban az entitásalapú megközelítés megvalósitója a BIBFRAME adatcsereformátum, amelynek leglényegesebb eleme, hogy a müvet tekinti a feldolgozás központi egységének. Az entitásalapú katalogizálási szabvány, az RDA (Resource Description and Access) utat jelent ahhoz, hogy a katalogizálás során ne betüsorokat, hanem entitásokat jelző egyértelmü azonosítókat adjunk meg az egységek azonositásánál. Az entitások összekötésének alapvető adatmodellje a bibliográfiai tételek funkcionális követeményeire vonatkozó FRBR - Functional Requirements for Bibliographic Records (amely nemcsak a könyvtári, de a múzeumi és levéltári világban is kialakitotta a szakterületnek megfelelő adatmodelljét).

A könyvtári platformot megvalósitó szoftver esetében is az entitás-alapú megközelítést célszerü követnünk, mert ezáltal képes a teljes rendszer kielégiteni a legindividuálisabb követelményeket úgy, hogy egy univerzális képességü, felhőben üzemeltetett platformon a munkafolyamatok a legmesszebbmenőkig testreszabottan legyenek kialakithatók. Ebben az entitás a legatomibb egységre szedett funkció, a microservice, tulajdonképpen egy kicsi zárt entitás, amely képes sokféleképpen és sok más entitással kapcsolódni. A fejlesztés során olyan alapelvek figyelembevételével dolgoznak az informatikusok, amelyek alapján az egységek saját magukon belül teljesen szabadok (programozási nyelv, adatmodell, felépítés tekintetében), és a külső kapcsolódások a többi microservice-el szabadon alakithatók.

Az eddigiekben felvázolt entitások, az adat-entitások, a résztvevő-entitások (könyvtárak, munkatársak stb.) valamint a szoftver-entitások sokszínü kapcsolódása az alapja annak a nyiltt forráskódú könyvtári platform fejlesztésnek, amelyet sok ország sokféle könyvtáros közössége együttes erövel tervez és specifikál, és sok informatikus fejlesztö valósít meg. A FOLIO mozaikszó jelentése: a könyvtárakjövője nyitott - the Future of Libraries is Open. Az Országos Széchényi Könyvtár által 20172019-ben lebonyolított nyílt nemzetközi tárgyalásos tenderen több induló közül 
ez a megoldás nyert, és 2019 áprilisában a nyertes pályázó aláirta a Kormányzati Informatikai Fejlesztési Ügynökséggel (KIFÜ) azt a szerződést, amely alapján 2020 év végéig a KIFÜ felhő alapú, georedundáns infrastruktúráján a nyertes szállitó által az Országos Könyvtári Platform installálásra kerül. Ez a platform a tender követelményekben meghatározott funkcionalitásokat valósítja meg. 2020 végén az OSZK és a Könyvtártudományi Szakkönyvtár összes meglévő szolgáltatását (az országos szolgáltatásokat, közös katalógus, könyvtárközi kölcsönzés stb. is beleértve) ebben fogja megvalósitani, 2021-töl pedig nyitva áll a platform, hogy bármely magyar könyvtár beköltözzön, akár teljes funkcionalitását megvalósítva, akár valamely szolgáltatását illetően. Ahhoz, hogy ne csak a nemzeti könyvtár funkcióit, hanem bármilyen egyetemi, akadémiai, egyházi, közkönyvtár stb. funkcióit is maradéktalanul megvalósithassa a platform, már a tenderkiirás elkészitésébe hat nagy, különböző funkciójú magyar könyvtár szakemberei kapcsolódtak be - és ezek és más könyvtárak is részt vesznek a követelmények pontositásában, és a rendszer kidolgozásában, végső soron megvalósitásában, tesztelésében.

Az elmúlt két évben három modul készült el és került bevezetésre, mintegy a fent vázolt entitásalapú platform elökészitéseként.

A katalogizáló modulban a metaadatok elkészitésének alapja a nagyon szabadon definiálható struktúra, a séma. Meghatározzuk a leírni kivánt tartalomtipust, és ehhez tulajdonságokat rendelünk, értéksablonokkal. Elkészitjük a kötött szótárak értekeit adó címkéket és azok rendszerezését. A leírás és a leírt digitális objektum egységet képez.

Ameddig a saját rendszerünkben dolgozunk, teljesen szabadok vagyunk a tulajdonságok meghatározásában, azok hierarchiájának kialakitásában. Ha a külvilághoz szeretnénk kapcsolódni, akkor nemcsak a szoftverünk kell csatlakozóképes legyen, hanem az adataink is: azaz a külvilág számára értelmezhető (ideális esetben standard) formátumba kell öket hoznunk, de már a tulajdonságok által felvehetö értékek meghatározásakor érdemes olyan értékkészletet választani, amely a külvilág számára is közvetlenül értelmezhetö, de legalábbis külsö azonositóknak megfeleltethetö. 


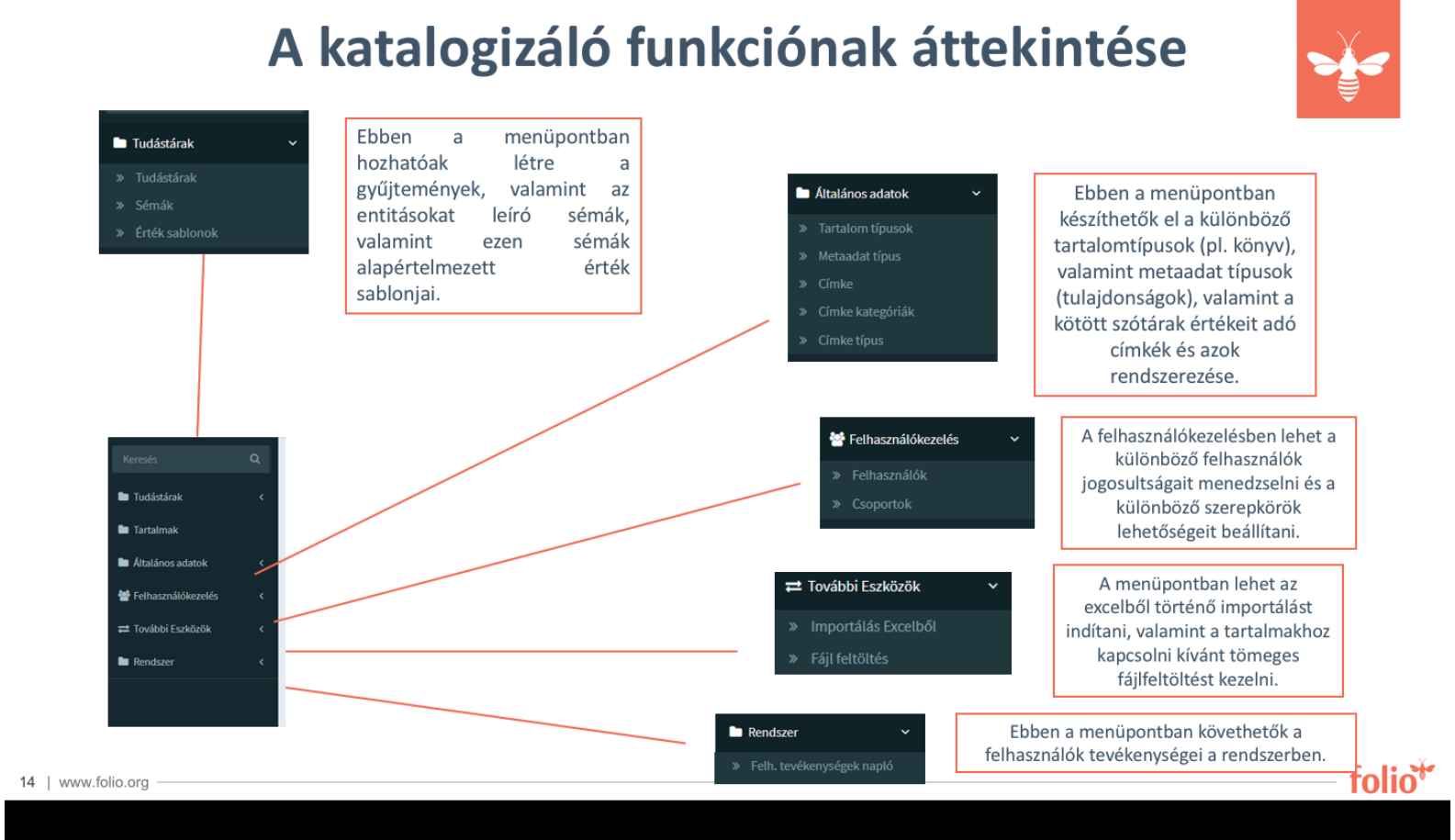

Emiatt elengedhetetlen jelentőségü a Nemzeti Névtér létrehozása, amely célszerüen túlmutat a könyvtári világ határain. A Névtér olyan konzorciumban müködik, ahol az adatok gyarapításában más típusú kulturális intézmények és más nem kulturális területen tevékenykedő intézmények egyaránt részt vesznek. Tetszöleges típusú névterek hozhatók létre a platformon, eddig a személy-, testületi- és geo-névtér valósult meg. Az entitások azonositásának alapja a nyelvi modell - az adott nyelvben szereplö összes jelentésnek saját egyedi azonositója van. A szoftver megvalósitja egy modern platform összes lényeges jellemvonását: képes az adatok közötti hierarchikus viszonyokat paraméterezhető módon leírni, flexibilisen kialakitható munkafolyamatok definiálhatóak, létezik az adatjavitást és gazdagítást megvalósitó szerkesztöségi együttmüködés, nemcsak az intézményi együttmüködés, de intézményen kivül tevékenykedő hozzáértők bevonása is lehetséges a flexibilis jogosultságkezelés alapján (citizen science, crowdsourcing), a rendszer képes a kitüntetett névalakok és a versengö adatok kezelésére, valamint képes lokális névterekkel összekapcsolódni, több módon: felterjesztés szinkronizálás - származtatás. 


\section{Nemzeti Névtér}

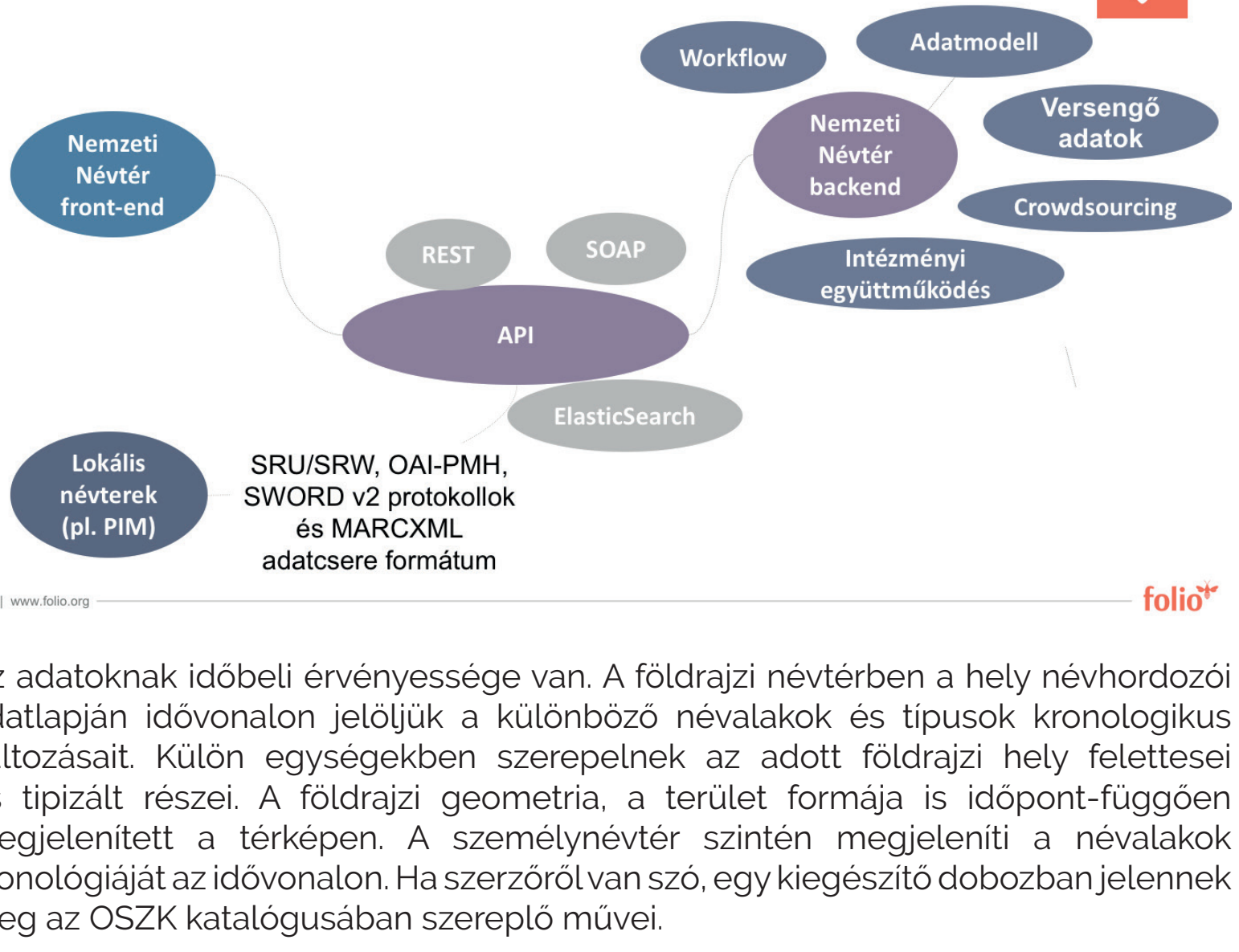

A Névtér, a maga azonositóival és jól definiált, gazdag egységeivel az entitáskoncepció legtisztább megvalósulása.

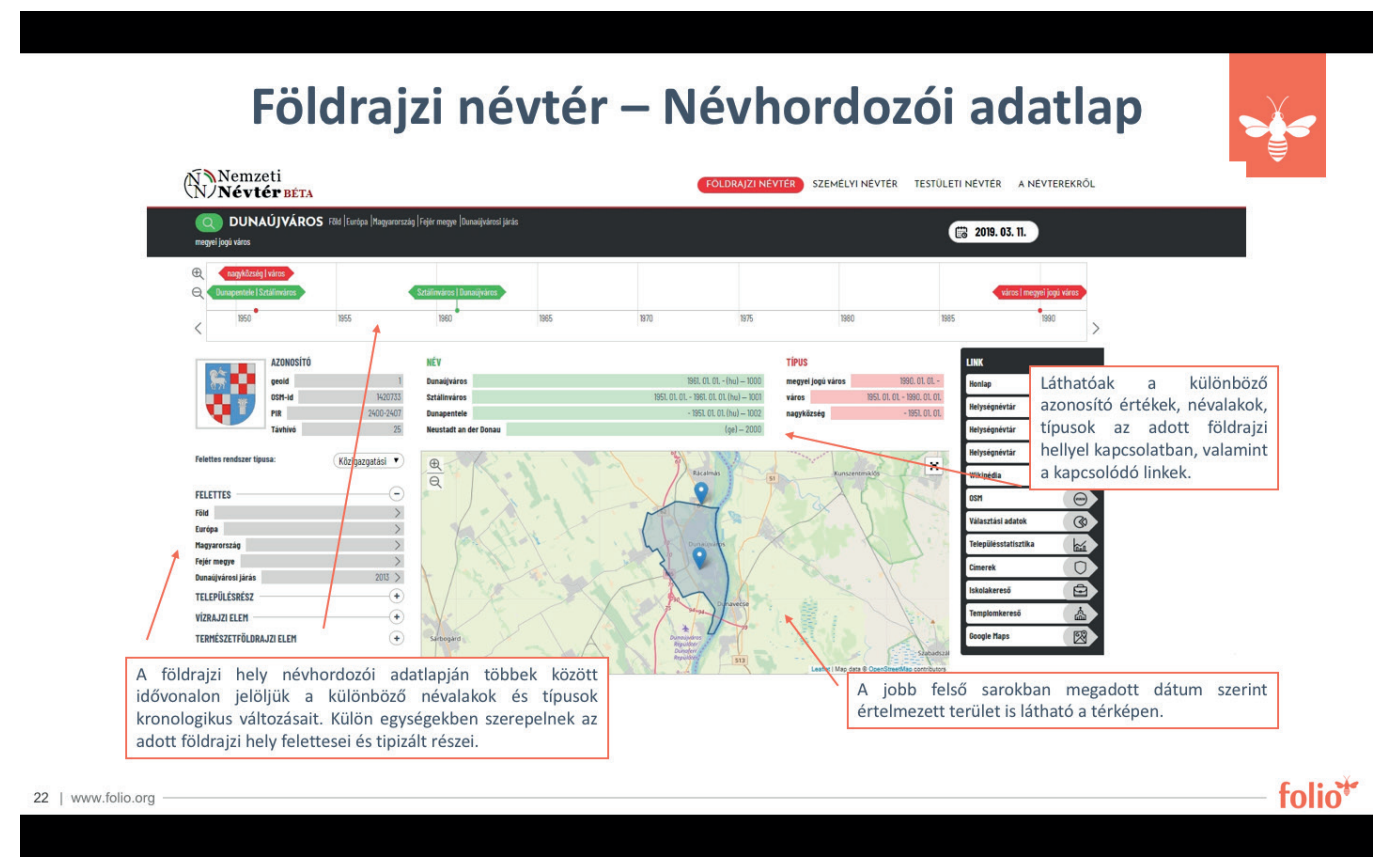


A legkülönfélébb forrásból származó szövegek esetén van szükségünk arra, hogy értelemszerü összefüggéseket tárjunk fel a szöveg tartalmi, lényegi jelentéséböl levezetve. Ezt szolgálja az integrált szövegkereső modul. Ez feldolgozza a digitalizált anyagok optikai szövegfelismeréssel (OCR - Optical Character Recognition) elökészitett szövegeit, egy automatikus helyesirás ellenörzés (HunSpell) és beépitett algoritmusok segitségével javitva az értelmezhetöséget. Ezután következik a szótövezés, nyelvi feldolgozás, szövegbányászat, azaz a szöveg feldolgozása. Majd a kereshetöség érdekében a Solr search-engine segitségével az adatok indexelése történik. Az entitások felismerése után egy NoSQL gráf adatbázis (Neo4J) tárolja az entitásokat és a közöttük levő kapcsolatokat. A szinonimák kezelésére, szemantikus összekapcsolására ontológia-és tezauruszmenedzsmentet használunk. A felhasználó számára fazettás, kulcsszó alapú és teljes szövegben való keresés egyaránt elérhető ezáltal. A gép tanitható ember által, és ez fontos eleme a hatékonyabb feldolgozásnak.

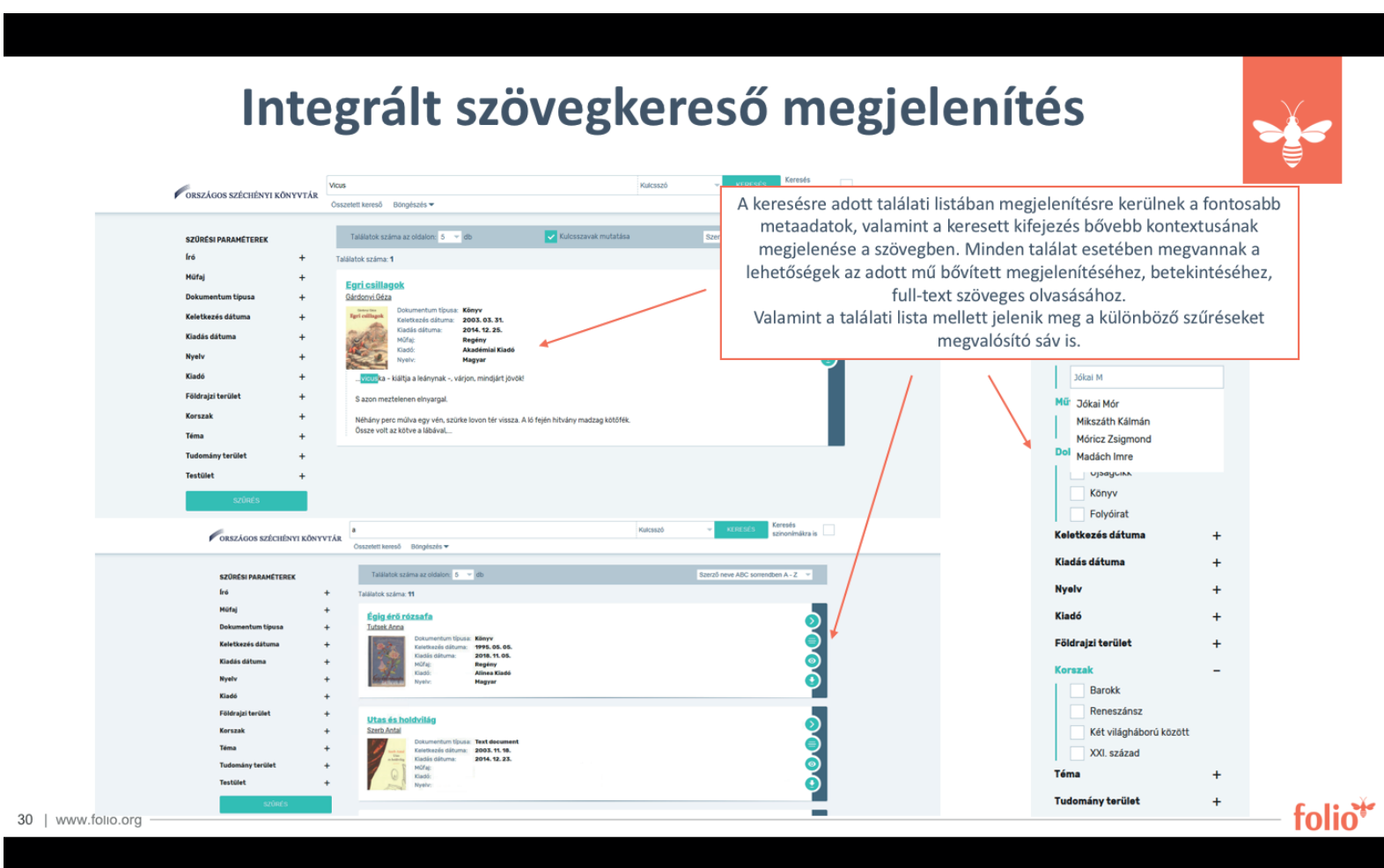

Készülve az új megvalósuló Országos Könyvtári Platformra, szükségszerü a meglévő adatok minél alaposabb konszolidálása. Ez a munka másfél éve folyik, melynek során egy köztes platformra való betöltés érdekében gyüitjük az adatokat, szürjük a duplumokat, és az adatokat a MARC21 adatcsereformátum aktuálisan érvényes szabványos formájára konvertáljuk, figyelembe véve az RDA katalogizálási szabvány újdonságait is. 


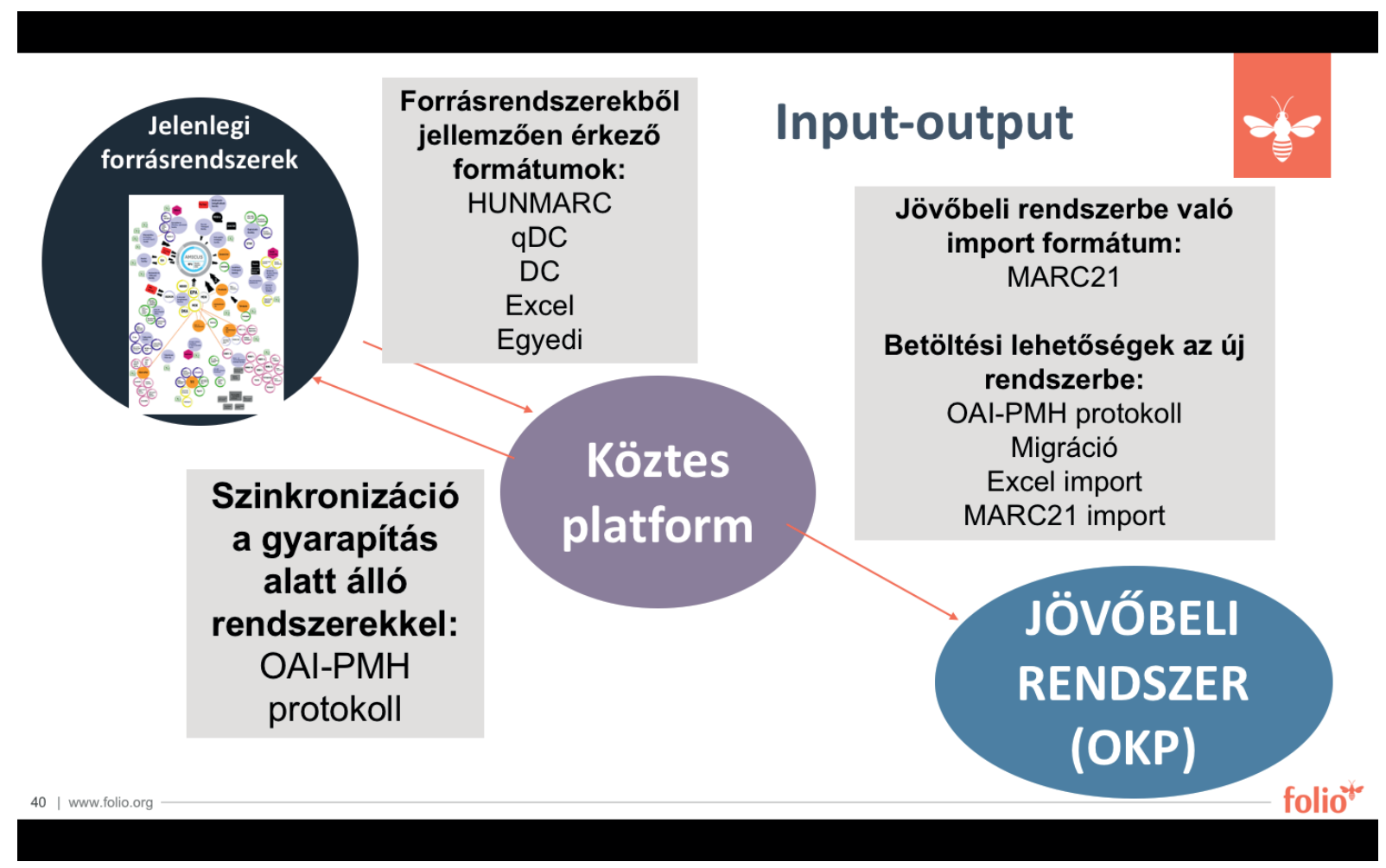

Mindhárom fejlesztés központi eleme az adatok elemekre, entitásokra tagolása. Ez az újfajta megközelítés teszi lehetővé, hogy nem kell a munkát többször elvégezni, támaszkodni lehet a megbízható és ismert forrásból származó feldolgozott adatokra. A kapcsolódásokon keresztül olyan lehetőségek nyílnak meg a feldolgozók és a végfelhasználók (olvasók) előtt egyaránt, amely az adatok soha nem látott komplexitását képes feltárni, szemantikus, értelmes módon. A bevont adatgazdagitók köre jelentősen tágul, lehetővé téve a széleskörü és szakértő módon történö feldolgozást.

A célunk tehát egy olyan központi szolgáltatás, amely paraméterezhető módon kínál individuális megoldást minden bekapcsolódó résztvevőnek. Az adatfeldolgozás és a szoftverfejlesztés egyaránt nyitott, várjuk ennek a lelkesitően újszerü, új generációs platformnak a megalkotásába, fejlesztésébe a bekapcsolódni vágyókat! Biztosak vagyunk benne, hogy a nemzetközi együttmüködésben egy hosszabb távon fenntartható, nyelveken és kultúrákon átívelö, együttmüködő, megosztott eszközt leszünk képesek létrehozni, amely messze túlmutat a piacon jelenleg megtalálható monolitikus megoldásokon. Az apró entitások teszik lehetővé, hogy ez a komplexitásában soha még nem látott, összetett platform olyan módon fejlődhessen a jövöben, hogy egyes elemei úgy újulhassanak meg, hogy a teljes egész szervesen gyarapodva, folyamatosan müködni legyen képes.

Büszkék vagyunk az eddig elért eredményeinkre, és örömmel tekintünk az elöttünk álló kihivások elébe. Örülünk, amennyiben minél több könyvtár és fejlesztő bekapcsolódik ebbe a munkába! 


\title{
Open Access pályázati rendszer technikai megvalósítása és a szerzők támogatása a Szegedi Tudományegyetemen
}

\author{
Muzs Krisztina \\ SZTE Klebelsberg Könyvtár \\ krisztina.muzs@ek.szte.hu \\ Molnár Tamás \\ SZTE Klebelsberg Könyvtár \\ tamas.molnar@ek.szte.hu \\ Hoczopán Szabolcs \\ SZTE Klebelsberg Könyvtár \\ szabolcs.hoczopan@ek.szte.hu
}

\begin{abstract}
A Szegedi Tudományegyetem Open Access stratégiájának meghatározó része a támogatás nyújtása a szerzők nyiltt hozzáférésü publikációinak közlési dijának fedezéséhez, a megfelelő folyóirat kiválasztásához illetve a szerzői támogatás biztositása. Egy Szegedi Tudományegyetem méretü intézményben a saját büdzséböl fizetett, vagy konzorcionális forrásból fedezett publikációs költségek, illetve az eleve nyiltt hozzáférésünek szánt cikkeken felül, a rendelkezésünkre álló, egyre növekvő számú, opcionális (Read and Publish) Open Access közlési lehetőség adminisztrációja komoly kihívás a munkafolyamatba bevont kollégák számára. Nemcsak a ténylegesen elfogadott közlemények igénylik kollégáink figyelmét, de a készülőben és az utánkövetés alatt lévők is, szigorú összhangban az intézményi Open Access támogatási szabályzattal.

A szerteágazó feladatok ellátásához szükségünk volt egy online adminisztrációs rendszere, mely számos automatizmussal könnyiti meg kollégáink munkáját, és minden számunkra fontos funkciót egy felületen tesz elérhetővé a támogatási döntéshozatal elökészitésétöl kezdve a pénzügyi adminisztráción keresztül a publikációk utánkövetéséig. A rendszer szükségszerüen összehangolva müködik az egyes kiadók saját online Open Access adminisztrációs felületével, máskülönben nagyon hamar elvesznénk az adatok tengerében. Az adminisztrációs rendszer része a Szegedi Tudományegyetem publikálás támogató felületének, a Szerzői Eszköztárnak.
\end{abstract}

The main part of the University of Szeged Open Access strategy is the provision of support for the payment of APCs, the selection of the appropriate journal and the author support. In an institution like the University of Szeged, where publishing costs are paid from several budgets or covered by many consortium contracts, and in addition the Open Access born articles, the administration of the increasing number of optional Open Access possibilities is a serious challenge for the colleagues involved in the workflow. Of course not only the accepted publications requiring the attention of our colleagues, but also the under preparation articles and the follow-ups, in strict accordance with the institutional Open Access policy. 
Muzs Kriszina - Molnár Tamás - Hoczopán Szabolcs: Open Access pályázati rendszer technikai megvalósitása és a szerzők támogatása a Szegedi Tudományegyetemen

In order to perform diverse tasks, we needed an administrative system that facilitates the work of our colleagues with a number of automations and provide every important function for us, from the preparation of decision making through financial administration to the follow-up. The system will necessarily work with each publisher's own Open Access administration interface, otherwise we would be lost in the sea of data very soon. The administration system is part of the so-called Author's Toolbox, which provide more and more author support services for the University of Szeged.

Keywords: open access, Article Processing Charge, Read and Publish, institutional author support

\section{A szerzők támogatása}

Az SZTE Klebelsberg Könyvtár 2015-ben kezdte meg a Szerzöi Eszköztár ${ }^{1}$ projekt keretében az egyetem szerzőinek publikációs támogatását. A Szerzői Eszköztár valójában egy folyamatosan bövülö "szolgáltatás csokor" melyben az egyetem szerzőit kivánjuk segíteni a publikációs folyamat során felmerülö problémák megoldásában. Természetesen senki helyett nem írjuk meg a cikkét, de segitséget nyújtunk a folyóirat kiválasztásban, publikációs workshopok szervezésében, az előzetes lektorálásban, plágiumellenörzésben, a publikációs költség fedezésében, a repozitálásban, az MTMT feltöltésben és a szerző jogi kérdésekben².

Az utóbbi időben a szerzőket támogató szolgáltatásaink mellett elindítottuk a szerkesztőségeket támogató szolgáltatásainkat, melynek keretében Open Journal System alapú folyóirat platformot, és technikai támogatást biztositunk az egyetemi folyóiratok számára, hogy szabályos Open Access folyóiratként jelenhessenek meg. A platformon futó folyóiratok esetében a megszülető cikkeket digitális objektum azonositóval, és ezzel plágiumvédelemmel látjuk el. A szerkesztőségek kérésére a folyóiratplatformunkat összekötöttük a CrossCheck plágiumellenőrzö rendszerrel is, igy akár minden a szerzök által beküldött cikk, automatikusan plágiumellenörzésen is áteshet. Az esetlegesen felmerülö szerzői jogi ügyletek rendezésére az egyetem a Copyright Clearence Centerrel áll kapcsolatban, hogy az esetlegesen az egyetem szerzői által benyújtott cikkekben szereplö külső forrásból felhasznált ábrákra, szövegrészekre stb. gördülékenyen tudjunk újrafelhasználási engedélyeket szerezni³.

Magának a publikációs támogatási programnak a következő alapvető céljai vannak: segiteni a szerzőket a nyilt publikációk megjelentetésében, az ügyintézés gyorsitása, az SZTE láthatóságának növelése, a nemzetközi rangsorokban való

\footnotetext{
1 Keveházi Katalin. Nyilt hozzáférés a gyakorlatban. Tudományos és Mûszaki Tájékoztatás 63 5. sz. (2016.), 193-197.

2 Dr. Meskó Eszter. Kutatást támogató könyvtár, a tartalomszolgáltatástól a tartalomgazdaságig. Networkshop 2016 konferencia, Tartalomszolgáltatások https://kifu.videotorium.hu/hu/recordings/12958/kutatast-tamogato-konyvtar-atartalomszolgaltatastol-a-tartalom-gazdasagig

$3 \quad$ http://szerzoknek.ek.szte.hu
} 
elörelépés elősegítése, az MTMT feltöltöttségének javitása és általánosságban az Open Access ügyének támogatása.

Az utóbbi években azt tapasztaltuk, hogy az Open Access publikációk körüli adminisztráció legalább annyira munkaigényes, mint az elöfizetések intézése. Az egyetlen szervként, ami intézményi szinten vállalja fel a nyiltt hozzáférés adminisztrációját, a kiadók számára a Szegedi Tudományegyetem Klebelsberg Kuno Könyvtára vált az elsődleges kapcsolattartóvá, így azok az esetek többségében nem csak azokkal a beküldött cikkekkel keresnek meg minket, melyek szigorúan véve a támogatási körünkbe tartoznak, hanem minden egyetemi publikációval kapcsolatban. Tulajdonképpen annak köszönhetöen, hogy a tagsági szerződéseket könyvtárként kötöttük meg a kiadókkal, rálátást nyertünk majdnem minden, az egyetemen megszülető Open Access, vagy potenciálisan azzá alakitható publikációra.

\section{Open Access támogatási feltételek}

A fentiekböl következöen az elsödleges feladatunk, hogy még a kiadói rendszerben megfelelö irányba indítsuk el a cikkek ügyintézését: a központilag támogatott publikációkat a könyvtár kiadói adminisztrációs rendszerben kialakitott munkaterülete felé, a többit pedig a szerzök felé irányitva. Ahhoz, hogy pontosan tudjuk, melyik feltöltéssel mi a teendönk, szükségünk volt egy átfogó egyetemi Open Access adminisztrációs rendszerre, amely már elözetesen minden adatot tartalmaz a gyors döntéshozatalhoz.

Az egyetemi Open Access támogatást az intézmény olyan feltételekhez kötötte, melyek mind a szerzőknek, mind az egyetemnek hasznosak. A feltételek ugyan folyamatosan változnak, követve az új lehetöségeket, igényeket és kihívásokat, de alapvetően az alábbi pontokkal kezdtük meg a munkát: a folyóiratnak tiszta Open Accessnek és Q1-Q2 besorolásúnak kell lennie. A levelező szerzönek SZTE-s affiliácójúnak kell lennie, a cikket SZTE-es email címmel kell feltölteni, aZ SZTE-s társszerzők arányának magasabbnak kell lennie 50\%-nál, a szerzők 2014 óta megjelent publikációinak szerepelnie kell az MTMT-ben és a repozitóriumban. A szabályok egyértelmü célokat szolgálnak: a célfolyóiratok első két kvartilise elősegiti a szerzőknek az idézetek megfelelö számát, ami az egyetem érdeke is, az SZTE-s email cím egyértelmüsíti az affiliációt. Az MTMT és a repozitórium minél alaposabb feltöltöttsége pedig a szerző és az intézmény közös érdeke.

\section{A Read and Publish szerződések beillesztése}

A feltételeket folyamatosan alakitják azok a Read and Publish ${ }^{4}$ publikációs szerződések, amelyeket az egyetem köt az EISZ konzorciumon keresztül. Ezen szerzödések, összehasonlitva a korábbi, egyetemünk által kötött szerződésekkel a Gold Open Access kiadókkal, nagyon kedvezményes és nagyszámú publikációs lehetőséget biztositanak, a tiszta Open Access-en felül a hibrid típusú folyóiratokban is 5 .

\footnotetext{
4 Az olvasáshoz és a nyilt publikáláshoz való jogot egyben kezelő szerződés a kiadókkal

5 Dér Ádám. Könyvtári és konzorciumi kezdeményezések az Open Access átállás elősegítése érdekében. ELTE Egyetemi Könyvtár és Levéltár, Hagyományok és kihivások VI. http://videotorium.hu/hu/recordings/26100
} 
Muzs Kriszina - Molnár Tamás - Hoczopán Szabolcs: Open Access pályázati rendszer technikai megvalósitása és a szerzők támogatása a Szegedi Tudományegyetemen

Már a kezdetekkor alapvető döntést kellett hozzunk. A R\&P szerzödéseknek nem feltétlenül kellett volna betagozódniuk a már megkezdett OA programunkba, müködhettek volna függetlenül, felhasználási feltételek nélkül. Azonban azt tapasztaltuk, hogy az OA adminisztrációs felületek (dashboard) kezelésére ugyanúgy könyvtári munkaerőt kell dedikáljunk, ráadásul rengeteg extra feladatot jelent a szerzők folyamatos tájékoztatása. İgy az tünt a logikus lépésnek, hogy a meglévő struktúrába illesztünk be minden elérhetővé vált új forrást.

2018-ban ezek a típusú szerződések még kuriózumnak számitottak, így a fenti feltételrendszerben egyfajta kivételként szerepeltettük öket, hiszen nem tiszta Open Access kiadókról beszélhettünk, és a rendelkezésre bocsájtott publikációs kereteket igyekezni kellett kitölteni. Időnként a folyóirat színvonalából is engedtünk, hogy ne menjen veszendöbe a rendelkezésre álló OA kvóta.

A 2019-es évre annyi Read and Publish típusú szerződést kötött a Szegedi Tudományegyetem az EISZ konzorciumon keresztül, hogy számszerüleg sokkal több Open Access publikálási lehetőséghez jutottunk hozzá, mint amennyit a hagyományos Gold OA vonalon fedezni tudtunk volna. Így az vált kihivássá, hogy a rendelkezésre álló kereteket hasznosan töltsük ki, valamint ne menjen veszendöbe egyetlen APC sem ${ }^{6}$. Az első nagyobb kiadói szerződés, mely azonnal átütő sikerrel indult az SZTE-n, a Springer Nature-rel kötött volt?.

Nyilvánvalóvá vált, hogy a korábbi gyakorlat, amikor kivételként, eseti elbírálással kezeltük a Read and Publish típusú publikálási igényeket, nem tartható tovább, hiszen az arányokat tekintve komoly eltolódás történt. Az eredetileg tiszta nyílt hozzáférésü folyóiratokra kidolgozott szabályokat nem akartuk megváltoztatni. Ezeket a roppant drága APC-ket ${ }^{8}$ a tiszta OA folyóiratokban továbbra is csak komoly elözetes szürést követően, az egyetem érdekeit szem elött tartva akartuk átvállalni a szerzőktől. A költségkímélőbb R\&P kvótákat viszont maradéktalanul fel szerettük volna használni, minél több szerzöt bevonva ezzel a programba. Emiatt megfogalmaztunk egy második szabályrendszert, ahol engedményeket tettünk az elözőekhez képest. A folyóiratok besorolását tekintve a harmadik kvartilisbe tartozó címeket is elfogadtuk, az SZTE-s szerzök arányát pedig mindössze 30\%ban határoztuk meg. A választóvonal a két szabályrendszer között a megkötött R\&P szerződések mentén húzódik, szerzőinket gyakran tájékoztatni kell, hiszen könnyedén elveszhetnek az információk tengerében.

Az új "APC állományok" használatba vételekor nagyon hamar kiderült, hogy ezúttal az Open Access szerzői igényeket nem elég passzivan várni. Minden tájékoztatási erőfeszitésünk ellenére sok szerző nem értesült a lehetőségekröl, vagy nem tudja hogyan kell élni velük. Sok esetben, egy cikk elfogadásáról szóló kiadói értesitést

\footnotetext{
$6 \quad$ http://eisz.mtak.hu/index.php/hu/open-access.html

$7 \quad$ http://eisz.mtak.hu/index.php/hu/open-access/286-open-access-megallapodas-aspringer-nature-kiadoval.html

8 Article Processing Charge. A nyilt hozzáférésü folyóiratok esetében a cikk megjelentetéséért felszámított eljárási dij
} 
kézhez véve azt tapasztaljuk - a késöbb bemutatandó Open Access pályázati rendszerünkben -, hogy a szerző nem pályázott előzetesen. Feltehetőleg nem értesült az OA lehetőségröl, vagy félreértette a kiadói tájékoztatást. Ilyenkor egyenként megkeressük öket, ismertetve a publikálási lehetöségeket és azok feltételeit.

\section{Open Access adminisztrációs rendszer}

A fentiekböl kiolvasható, hogy az Open Access munkacsoportunknak nem csak a pályázatot igénylő, egyértelmüen más forrást használó, hanem a feltehetöleg hozzánk tartozó igényeket is kezelnie kell. Egy ilyen teljes intézményt átfogó adminisztráció elképzelhetetlen lenne, ha nem állna rendelkezésünkre egy olyan saját fejlesztésü rendszer, amely összeköti az összes résztvevöt, lehetővé téve a pályázatok adminisztrálását, a megszületett cikkek utánkövetését, valamint segitve a pénzügyi és APC adminisztrációt, abból fakadóan, hogy minden adatot egy felületen tárol. A szerző ebben a rendszerben szerkeszti és nyújtja be pályázatát, illetve az esetleges hiánypótlást, majd ezt követöen a könyvtáros kollégák elvégzik a döntéselökészitő ellenörzést, hogy az egyetem felsö vezetése meg tudja hozni a döntést. Így amikor egy kiadótól értesités érkezik egy SZTE affiliációjú OA vagy potenciálian Open Access cikk elfogadásáról, a munkacsoport tagjai már pontosan tudják, hogyadott cikketelutasitani,jóváhagyni kell, esetlega szerzöt kellmegkeresni tájékoztatás céljából. A pályázatokon minden olyan adatot bekérünk a szerzőktől, ami a pályázati feltételek ellenörzését lehetővé teszi, úgymint a folyóirat adatai, az APC várható összege, a szerzők MTMT, Scopus azonositója illetve ORCID-ja.

\section{Szegedi Tudományegyetem \\ Klebelsberg Kuno Könyvtára}

Tisztelt Teszt Elek

Beadott pälyázatának adatail

\begin{tabular}{|c|c|c|c|c|c|c|}
\hline \multicolumn{4}{|c|}{ Azonositó } & \multicolumn{3}{|c|}{4458} \\
\hline \multicolumn{4}{|c|}{ Kérelmezö neve } & \multicolumn{3}{|c|}{ Teszt Elek } \\
\hline \multirow{2}{*}{\multicolumn{4}{|c|}{ Kérelmezö e-mail címe }} & \multicolumn{3}{|c|}{ szabolcs.hoczopan@ek.szte.hu } \\
\hline & & & & \multicolumn{3}{|c|}{ BBMK - Bartók Béla Müvészeti Kar } \\
\hline \multicolumn{4}{|c|}{$\begin{array}{c}\text { Kar } \\
\text { Tanszék }\end{array}$} & \multicolumn{3}{|c|}{ Rézfúvós Tanszék } \\
\hline \multicolumn{4}{|c|}{$\begin{array}{c}\text { Tanszék } \\
\text { OA folyóírat címe }\end{array}$} & \multicolumn{3}{|c|}{ Open Access Journal } \\
\hline \multicolumn{3}{|r|}{$\begin{array}{l}\text { OA folyóírat címe } \\
\text { ISSN }\end{array}$} & ISSN & \multicolumn{3}{|c|}{$0001-5350$} \\
\hline \multicolumn{4}{|c|}{ Kiadó neve } & \multicolumn{3}{|c|}{ OA Publishing } \\
\hline \multicolumn{4}{|c|}{ Publikáció címe } & \multicolumn{3}{|c|}{ Open Publikáció } \\
\hline \multicolumn{4}{|c|}{ APC összege (Publikációs költség, a kiadó által használt devizában.) } & \multicolumn{3}{|c|}{2048 EUR } \\
\hline \multicolumn{4}{|c|}{ APC befizetés (várható) határideje } & \multicolumn{3}{|c|}{$2019 / 11 / 28$} \\
\hline \multicolumn{4}{|c|}{ Leadás időpontja } & \multicolumn{3}{|c|}{$2019 / 11 / 01$} \\
\hline \multicolumn{7}{|c|}{ Megjegyzés a pályázat elbírálóinak } \\
\hline \multicolumn{7}{|c|}{ Szerzök } \\
\hline Név & Affiláció & $\begin{array}{c}\text { Rendelkezik MTMT } \\
\text { szerzői azonosítóval? }\end{array}$ & \begin{tabular}{|c||} 
MTMT szerzői \\
azonositó
\end{tabular} & $\begin{array}{c}\text { Scopus } \\
\text { Author ID }\end{array}$ & ORCID & $\begin{array}{l}\text { Szerzö } \\
\text { tipusa }\end{array}$ \\
\hline $\begin{array}{l}\text { Próba } \\
\text { Szilärd }\end{array}$ & $\begin{array}{l}\text { Összehasonlitó } \\
\text { Jogi Intézet }\end{array}$ & Igen & 22221111 & & $\begin{array}{l}\text { https://orcid.org/0000- } \\
\text { 3333-2222-3333 }\end{array}$ & Elsö \\
\hline \begin{tabular}{|l|} 
Társszerzö \\
Päl
\end{tabular} & \begin{tabular}{|l|} 
Élelmiszermérnöki \\
Intézet
\end{tabular} & Igen & 33331111 & & $\begin{array}{l}\text { https://orcid.org/0000- } \\
\text { 3333-2222-1111 }\end{array}$ & $\begin{array}{l}\text { Nincs } \\
\text { megadva }\end{array}$ \\
\hline Teszt Elek & Rézfüvós Tanszék & Igen & 11112222 & & $\begin{array}{l}\text { https://orcid.org/0000- } \\
1111-2222-3333\end{array}$ & Levelezö \\
\hline Név & Affiláció & $\begin{array}{c}\text { Rendelkezik MTMT } \\
\text { szerzői azonosítóval? }\end{array}$ & $\begin{array}{l}\text { MTMT szerzői } \\
\text { azonositó }\end{array}$ & $\begin{array}{c}\text { Scopus } \\
\text { Author ID }\end{array}$ & ORCID & $\begin{array}{l}\text { Szerző } \\
\text { típusa }\end{array}$ \\
\hline
\end{tabular}

1. ábra Szerzöi adatlap 
A beérkezö adatok alapján az OA munkacsoport adminisztrátora elkezdi a döntéselökészitési adatolást. Megjelöli, hogy adott cikk melyikszerződés keretében, melyik szabályzat alapján lesz nyilt hozzáférésü. Leellenőrzi a megadott azonositók alapján, hogy a szerzök cikkei fel vannak-e töltve az MTMT-be és a repozitóriumba. A folyóirat esetében a Scopus és a Web of Science adatok alapján felviszik az adatlapra a kvartilis besorolást, ami a legfontosabb birálati szempontunk.

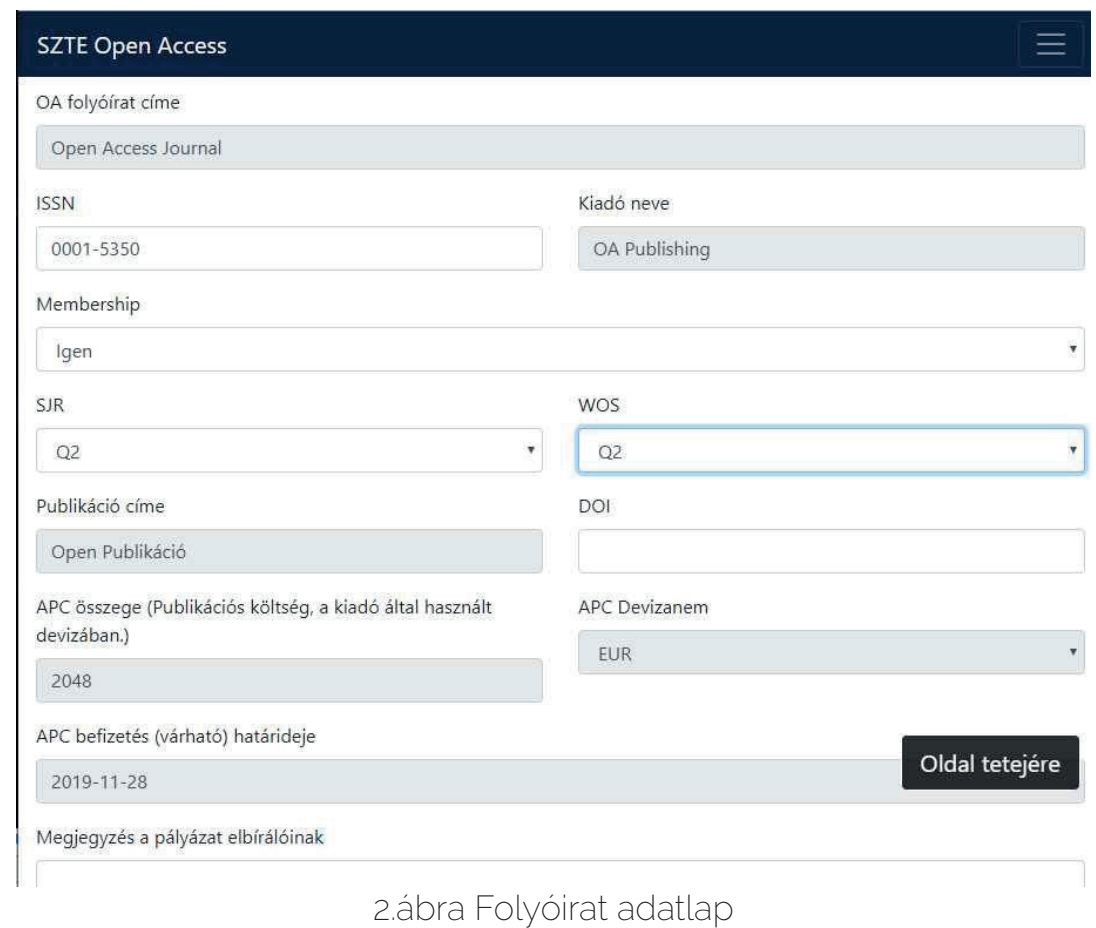

Amennyiben valamely feltételnek a szerző nem felel meg, pályázatát a könyvtári adminisztrátor elutasithatja, ha csak hiánypótlásra van szükség, akkor visszaküldheti a szerzőnek szerkesztésre, pontosan megjelölve, milyen adatokat kérünk még feltölteni.

Elöfordulhatnak kivételes esetek, például egy tudományterületen kevés nyilt hozzáférésű folyóirat érhető el és azok kvartilis besorolása is az általunk húzott határon billeg. Ebben az esetben az egyetemi felsövezetés automatikusan elutasitaná a pályázatot, azonban az ürlapba be lett épitve egy szabadszöveges mező, ahol az ilyen jellegủ kivételes pályázatokat meg tudjuk indokolni, adatokkal alátámasztani.

\section{Döntéstámogatás}

Ha lefutotta pályázatés a cikk megjelent, azOA munkacsoport munkája nemérvéget: a cikkek utóéletét is folyamatosan figyeljük, idézettségi szempontból. Erre a célra a megjelent cikkek DOl-jait gyüjtjük az adatbázisban, azokból épitünk egy egyedi 
entitást az Elsvier Scival tudománymetriai rendszerében. Ennek köszönhetöen folyamatos rálátásunk van az általunk finanszirozott cikkek idézettségére, valamint hatására.

Bár a módszer müködik, a DOI-k kézi gyüjtögetésénél professzionálisabb megoldásra volt szükségünk. Az utánkövetés egyszerüsitésére 2019 júniusától regisztráltuk magunkat a CrossRef FundRef adatbázisában. Az egyetem szerzőit arra kérjük, hogy a FundRef azonositónkat rögzítsék a cikk feltöltésekor. Az így rögzitett azonosító alapján a cikkeink már bármely bibliográfiai adatbázisból lekérdezhetők és elemezhetők lesznek.

Az elemzés és statisztikakészités másik vonulata a pénzügyi utánkövetés Mivel folyamatosan el kell számolnunk az egyetem felé az elköltött APC összegével, ezért természetesen az adatbázisba felvett APC összegek alapján folyamatos kimutatásokat készitünk. Az APC-k folyamatos monitorozásának a könyvelési szükségszerüségen túl, döntéselökészitö jelentősége is van. Amennyiben egy adott kiadónál a számlák összege, gyakorisága kiemelkedö, lehetőség szerint Open Access tagsági (membership) szerződést kötünk velük ${ }^{10}$. Ezzel a lépéssel a késöbbi kifizetésekböl kedvezményeket tudunk elérni, illetve az APC kifizetés idejét jelentősen redukálni tudjuk, ami a publikációs versenyben nem utolsó szempont.

Külön vonalat képvisel a pénzügyi adminisztrációnkban, hogy azon APC árakat is gyüjtjük, melyek Read and Publish szerződés keretében születő cikkekhez tartoznak. Nyilvánvaló, hogy itt klasszikus értelemben nem tudunk elszámolni a publikációs költségekkel, de egy-egy szerződés későbbi megitélésének szempontjából ez ugyanúgy fontos adat lehet, mint például a "Read" szerződési rész letöltési adatainak gyüjtése és elemzése.

\section{6. Összefoglalás}

A nyilt hozzáférésü publikációkkal kapcsolatosan nyilvánvalóan elképzelhető lenne másfajta ügyintézési metódus is, saját megoldásunkban nem titkoltan a központositott dokumentum beszerzési rendszerünket vettük alapul, ahol a központositott munkafolyamatban az SZTE Klebelsberg Könyvtár hozzáadott értéke az adminisztráció gyorsításában és az egyetemi szinten is jelentős mértékü megtakaritásokban mutatkozik meg. A központositásnak hála, hasonló eredményeket érhetünk el publikációs vonalon, bár a centralizáció 2019 tavaszán még nem teljesen fejeződött be. Az SZTE beszerzési szabályzatának módositása 2019 nyarára azon kevés APC adminisztrálását is az Egyetemi Könyvtár hatáskörébe utalta, melyek eddig el tudták kerülni a figyelmünket. Így már valóban minden feltétel megteremtődött a hatékony és központositott intézményi Open Access politikához. 
DOI: $10.31915 / N W S .2019 .16$

\title{
Haladó funkciók és innovativ fejlesztések az EPrints és Omeka szoftverek körében
}

\author{
Nagy Dóra \\ SZTE Klebelsberg Könyvtár \\ dora.nagy@ek.szte.hu \\ Nagy Gyula \\ SZTE Klebelsberg Könyvtár \\ gyula.nagy@ek.szte.hu \\ ORCID: 0000-0002-8391-2851
}

\section{Advanced features and innovative developments of softwares including EPrints and Omeka}

The University of Szeged Klebelsberg Library has been using EPrints for handling institutional repositories since 2010. As we have progressed together with the program, we have been continually trying to exploit most of its components. In the presentation, we focus on introducing features that may be less widely used within the framework of Hungarian practice. Furthermore, some of our own innovations will also be revealed, for example, the possibilities of setting-up subject headings to the EPrints, managing file formats beyond PDF, the experience of using the statistics module, and the flexibility of designing metadata input forms.

In addition to text documents, several image collections have been recently digitized in our library. Access to these images is not provided through the institutional repositories, we use another open source software called Omeka. This system is equipped with a wide range of customizations through various extensions. It is able to manage user and access types, perform geolocations and offer various crowdsourcing techniques (collaboration, commenting, and sharing). After a brief introduction to the Omeka, some practical solutions will be demonstrated: Which types of extensions are we using? What are our future plans concerning this service? Keywords: repozitórium, képarchivum, EPrints, Omeka, tárgyszórendszer, crowdsourcing

\section{Bevezetés}

A könyvtárak mindig is élen jártak a nyilt forráskódú szoftverek használatában, így nem meglepő, hogy az elmúlt évtizedben a magyar repozitóriumi hálózat is ilyen alapokon épült ki. Tanulmányunk első felében ennek a hálózatnak az egyik alapvető épitőkövét jelentő szabad szoftver, az EPrints repozitóriumkezelő rendszer kevésbé ismert, haladó lehetőségeit-funkcióit szeretnénk bemutatni (1.1.-1.6. fejezet). A második részben pedig egy a hazai gyakorlatban még kevésbé elterjedt, elsösorban képek és más médiaállományok kezelésére kifejlesztett ingyenes, Omeka nevü szoftver néhány bővitményének bemutatása olvasható (2.1.-2.2. fejezet). A programok általános szintủ ismertetésén túl elsősorban azokra a magasabb szintü müveleteket megvalósitó kiterjesztett szolgáltatásokra koncentrálunk íásunkban, amelyek használata még kevésbé gyökeresedett meg a hazai gyakorlatban. Erre próbálunk utalni irásunk címében a "haladó funkciók" szófordulattal. Azokat a 
plusz szolgáltatást nyújtó lehetőségeket nevezzük haladó funkcióknak, amelyek nem érhetőek el a szoftver alap telepitésekor, vagy esetleg valamilyen rejtett funkcióként jelennek csak meg. A bemutatott esetekben ezen funkciók teljes körü kihasználásához bővitmények telepitése, konfigurálása, esetleg önálló fejlesztések adaptálása is szükséges.

\subsection{EPrints - Statisztika bövítmény}

Ezek körébe tartozik az EPrints statisztika bővitménye, amely 35 hazai EPrints repozitóriumot tekintve csak 14 esetében van telepítve, melyböl 12 SZTE megvalósitású. Saját EPrints repozitóriumainkon kivül a BGE Publikációtárnál és Dolgozattárnál, valamint a Corvinus Disszertációk és Kutatások repozitóriumoknál érhető el ez a modul.

Maga az IRStats2 nevü statisztika bővitmény az EPrints Bazaar bövitménykezelö felületéröl telepithetö. Rengeteg féle statisztikai adatot kinyerhetünk segitségével. Többek között kilistázza a legtöbbször letöltött szerzöket és müveket, a repozitóriumban lévő tételek számát, az összes letöltésszámot, illetve a bővitmény telepitésétöl kezdve grafikonon is ábrázolja a letöltési adatokat, piros vonallal megjelenitve az összesitett átlagot. A bövitmény segitségével különféle jelentések elkészitése, illetve a tételek többféle szempont szerinti szürése is lehetséges. Kimutatható például a letöltések országonkénti forrása (térképen ábrázolva), évenkénti összehasonlítás végezhető a repozitórium gyarapodásáról, illetve a dokumentumok tipus szerint is megjelenithetőek grafikonon. Az eredmények XML, JSON és CSV formátumban exportálhatók. Az SZTE Publicatio Repozitóriumnál az egyes tételek összefoglaló oldalán szintén megjelenik az adott rekordhoz tartozó letöltési statisztika.

Az összes SZTE-s repozitórium nyitóoldalán elérhető a statisztika föoldalára mutató link, amely szabadon böngészhető. Felhasználóink pozitiv visszajelzései alapján helyes döntésnek bizonyult a statisztikai adatok nyilvánossá tétele, hiszen így pontos képet kaphatnak a repozitóriumban lévő anyagok használtságáról, ami tovább növelheti a népszerüséget és az érdekeltséget.

\subsection{EPrints - Kötegelt szerkesztési lehetőségek adminisztrátori felületen}

Munkánk során rendszeresen használjuk az adminisztrátori felületen elérhető kötegelt szerkesztési lehetöséget. Több száz rekord betöltésekor a Batch Editing Tool segitségével történik az élö archívumba mozgatás, emellett hatékonyan használható különféle metaadatok tömeges javítására. Ilyenkor az adminisztrátori felületen a 'Tételek keresése' menüben lekeressük a módositani kivánt rekordokat, majd a találati lista bal felső sarkában a 'Batch Edit' lehetőségre kattintva jutunk arra a felületre, ahol a legördülö menüböl kiválasztható az az EPrints mezö, amelyet korrigálni szeretnénk, majd a 'Hozzáadás' gombra kattintva írhatjuk be az új értéket. Öt féle müvelet hajtható végre, ami a mező típusától függően eltérő. Lehet törölni a mező teljes tartalmát vagy a tartalom egy részét, hozzáirni új adatot a meglévők elé vagy mögé, illetve karaktersorozatot cserélni. 


\section{Statisztika}

\section{Összes tétel}

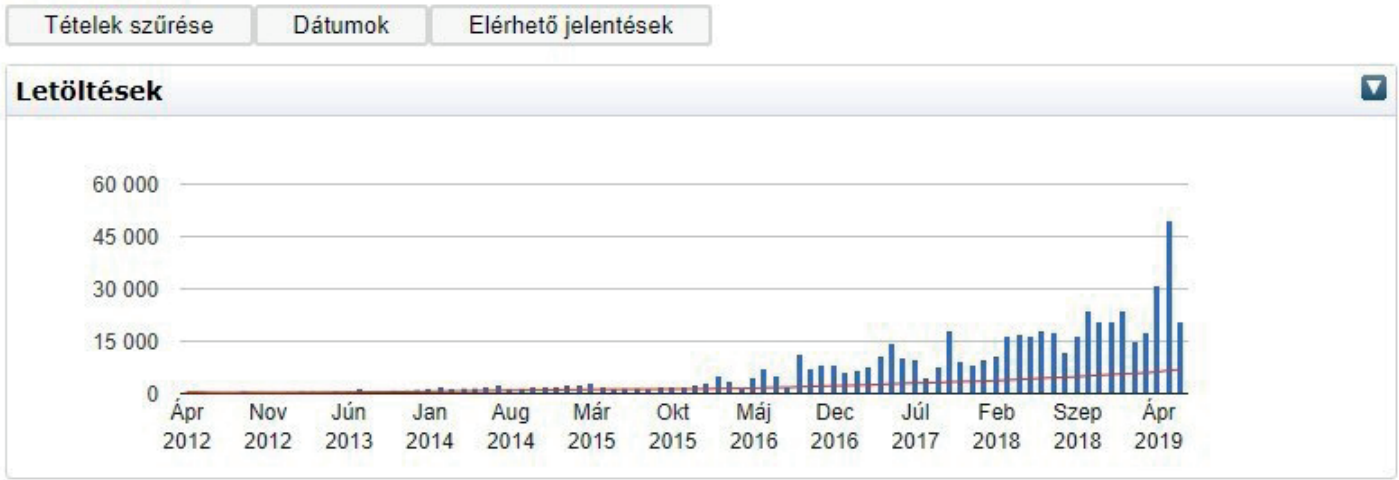

\section{Tevékenységek áttekintése}

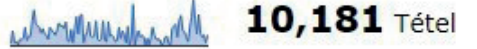

$\mathbf{1 0 0} \%$ Teljes szöveg
65\% Nyilt hozzáférés

\section{Legtöbbször letöltött tételek}

1. Melyiket válasszuk? - Tények és

1. érvek a diklofenák sókról

What is Privacy? The History and

2. Definition of Privacy.

3. Az európai integráció politikai története

\section{|ل 596,045 Letöltések}

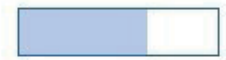

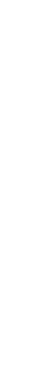




\subsection{EPrints - Összetett ürlap több szereplö kiszolgálására}

Az EPrints képes arra, hogy olyan beviteli ürlapot definiáljunk, amelynél az egyes mezökhöz és állomásokhoz csak bizonyos jogosultsággal rendelkezők férhetnek hozzá. Az SZTE Publicatio Repozitóriumnál és az SZTE Elektronikus Tananyag Archivumnál beépitettük ezt a lehetöséget, ugyanis ezek esetében külső felhasználók is töltenek fel anyagokat: előfordulnak olyan adatmezők, melyek csak a szerkesztők számára relevánsak, ezekkel nem akartuk feleslegesen terhelni a feltöltőket, emiatt számukra egy egyszerüsített ürlap jelenik csak meg a legfontosabb mezőkkel.

Emellett, a munkafolyamat konfigurációja során lehetöség van különbözö elágazások létrehozására is. Nem csak felhasználó, hanem EPrints típus szerint is változtatni lehet a különböző metaadatmezöböl álló ürlapokat: például videók esetében releváns a 'Lejátszási idő', míg könyv típusnál az 'ISBN'. A fent említett két repozitórium esetében a jogi nyilatkozatot is hasonló elágazással oldottuk meg. Ez a legelső állomás, melyre a felhasználó érkezik, ha új rekordot szeretne létrehozni, és csak akkor tud továbblépni, ha elfogadta a nyilatkozatot.

\subsection{EPrints - edulD}

Az SZTE Open Online Oktatás (SZTE O3) stratégia és az EFOP-3.4.3-16-2016-00014 projekt megvalósitásának részeként az SZTE Elektronikus Tananyag Archívum feladata az egyetemen keletkezett tananyagok hosszú távú megörzésének biztositása, szakszerü feldolgozása és szolgáltatása. A tananyagok megfelelő elérésének biztositására szükségessé vált egy új, eddigi repozitóriumainknál még nem használt hozzáférési típus bevezetése. Az edulD használatára több hazai adatbázisnál láthatunk példát (Szaktárs, Typotex), amely megoldás kivitelezhető intézményi repozitóriumoknál is. Jelenleg csak saját IDP-hez (Identify Data Provider) van bekötve az autentikáció, így egyelöre csak SZTE-s edulD-vel müködik a rendszer.

\subsection{EPrints - PDF-en túli fájlformátumok}

A repozitóriumokban általában PDF formátumban tároljuk, szolgáltatjuk a digitalizált vagy eleve elektronikusan keletkezett anyagokat, azonban az EPrints valójában sokféle fájlformátumot képes kezelni: MP3, ZIP, PPT stb. Ha az adott fájlformátumot a böngésző támogatja, akkor külső program igénybevétele nélkül, a böngészőben is megtekinthetőek a tartalmak. Ilyen formátumok a PDF, a HTML, a különbözö kép és videó fájlok (JPG, MP4 stb.).

Az SZTE Elektronikus Tananyag Archivumban elkezdtünk HTML oldalakat is archiválni, ugyanis rengeteg ilyen típusú tananyagot találtunk, melyeket nem lehetett PDF formátumba konvertálni az interaktiv megoldásaik miatt.

HTML oldalak archiválása a következöként történik: a lementett oldalt egy tömörített mappában feltöltjük EPrints-be, majd rendszeren belül kicsomagoljuk 'Single' módban, ezután lehet kiválasztani a fö fájlt (ami általában index.html). Nyilvános felületen a rekordban csak a fö fájl jelenik meg, a többi háttérben marad. Ezzel a megoldással felhasználóbarát módon lehet böngészni a weboldalt EPrints-en belül, nem kell a csomagot saját gépre letölteni. 
Tétel nézet: Fizikai optika

Ez a tétel URL címmel van az Repozitóriumban:

http://eta.bibl.u-szeged.hu/1693/

Tétel visszavonása

Mozgatás vissza a Feladatok kōzé

Tétel megsemmisitése

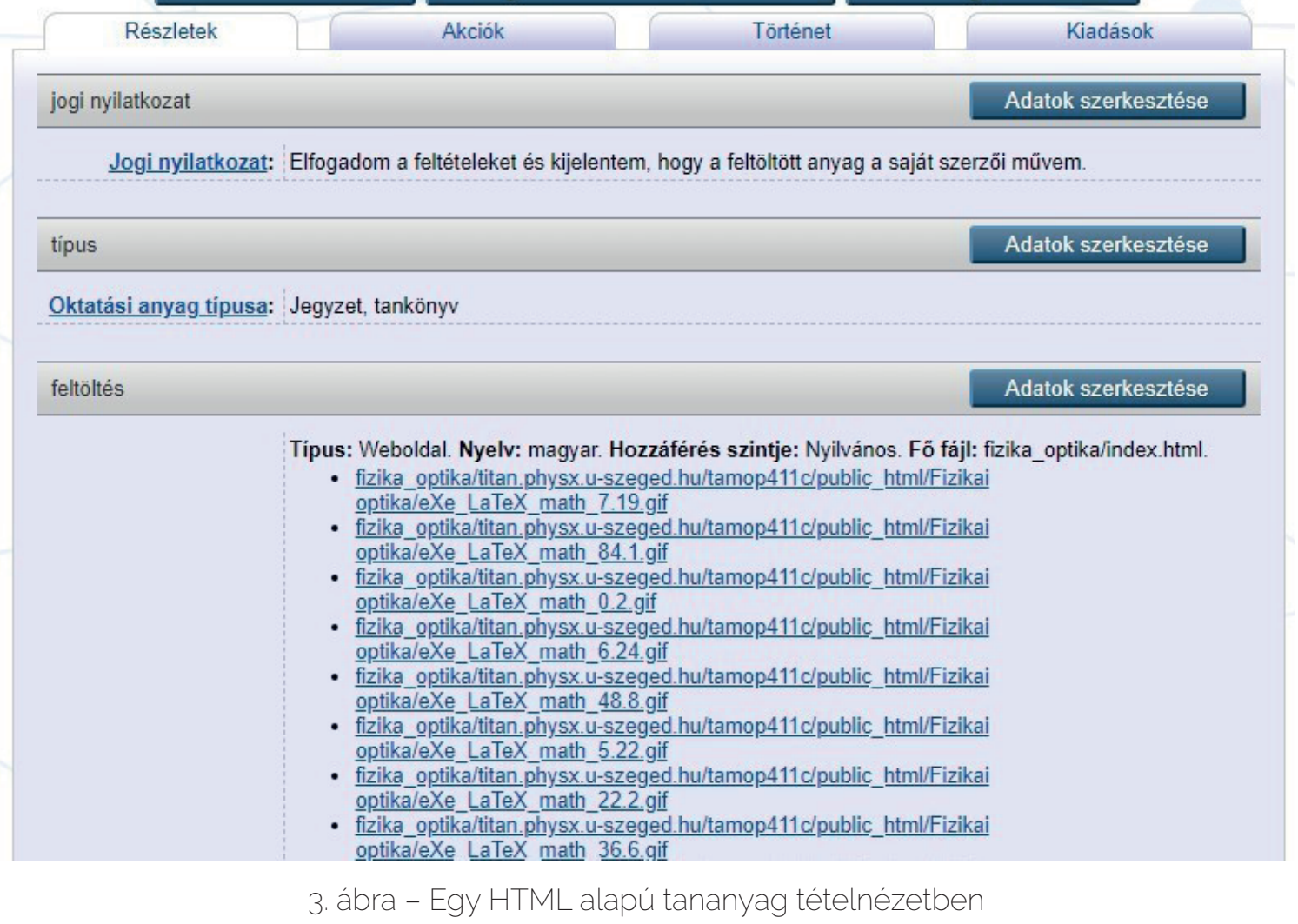

\subsection{EPrints - Szakterületi besorolás}

Mivel a tananyagok az egyetem minden karáról érkezhetnek, a tartalmi feltárást elösegitendő bevezettünk egy szakterületi besorolást. Ehhez a H2O2O projekthez készitetthétszintes, angolés magyar ${ }^{1}$ nyelven is rendelkezésreállótárgyszórendszert választottuk, melyet a megújult MTMT2 is beépitett. A taxonómia két ágra bomlik: "Tudomány" ( $N=\sim 3400) ;$ "Gazdálkodás és innováció" ( $N=\sim 300)$. Az EPrints illesztés során a témák mindegyike új ID-t kapott, illetve kivettük belőle a 'Gazdálkodás és innováció' ág kategóriáit. A táblázatot az elkészitett XML séma alapján EPrints-be

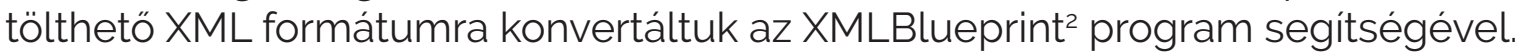

Az EPrints-en belül a 'subject' típusú mezö tartalmazza a tárgyszavakat, melyek módositására, kiegészitésére az adminisztrátori felületen van lehetöség. A rekord szerkesztési munkafolyamatában egy külön lapon kaptak helyet a szakterületek, melyek közül több is hozzárendelhetö egy rekordhoz. A külsö, nyilvános felületen a böngészés szakterület szerinti nézetben csak azok a kategóriák láthatóak, melyekhez van már rekord rendelve. Ezek tovább csoportosithatók szerző és oktatási anyag típusa szerint, valamint minden besorolt rekord tételnézetében is megjelennek a tárgyszavak.

\footnotetext{
$1 \quad$ A forditás Tichy-Rács Ádám munkája.

2 XML Editor - XMLBlueprint. https://www.Xmlblueprint.com
} 
(c)

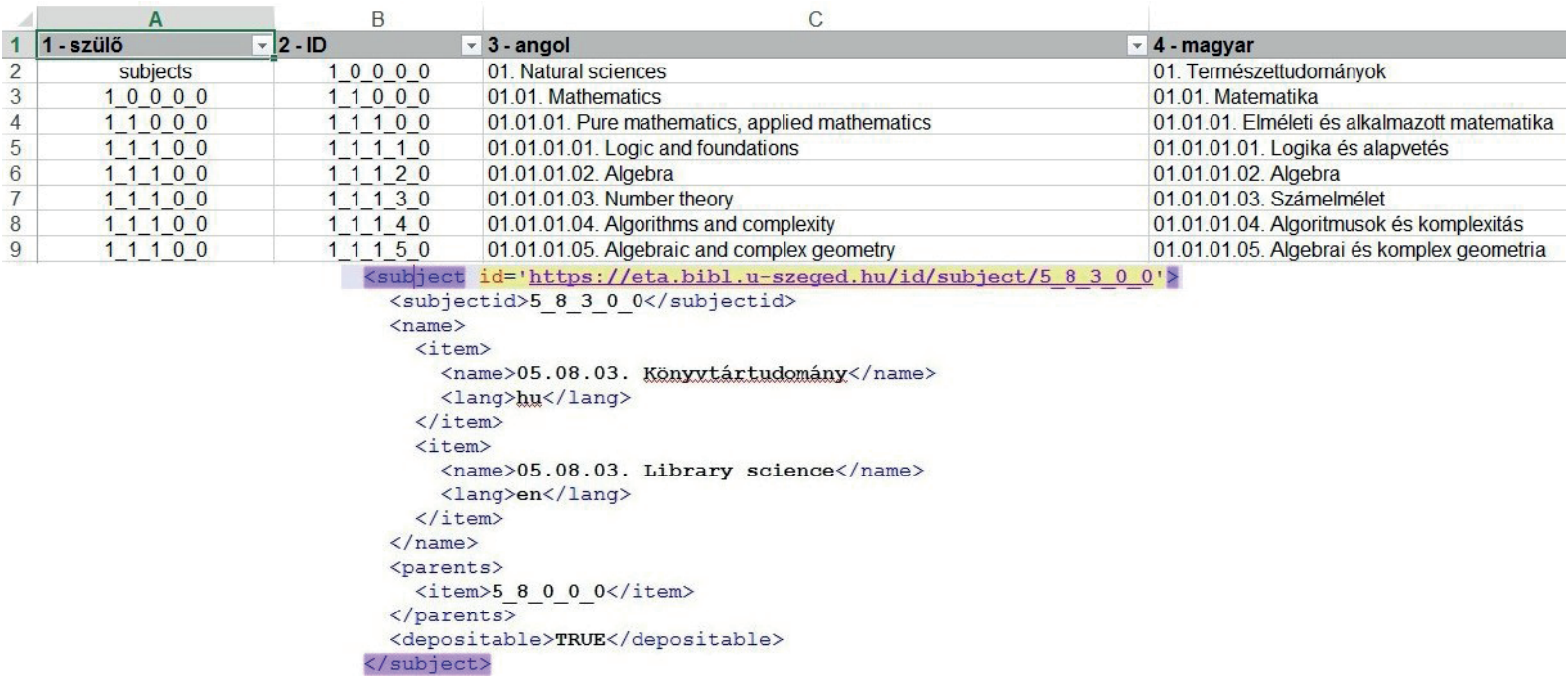

4. ábra - Az átalakitott táblázat, valamint a betöltésre kész XML részlete
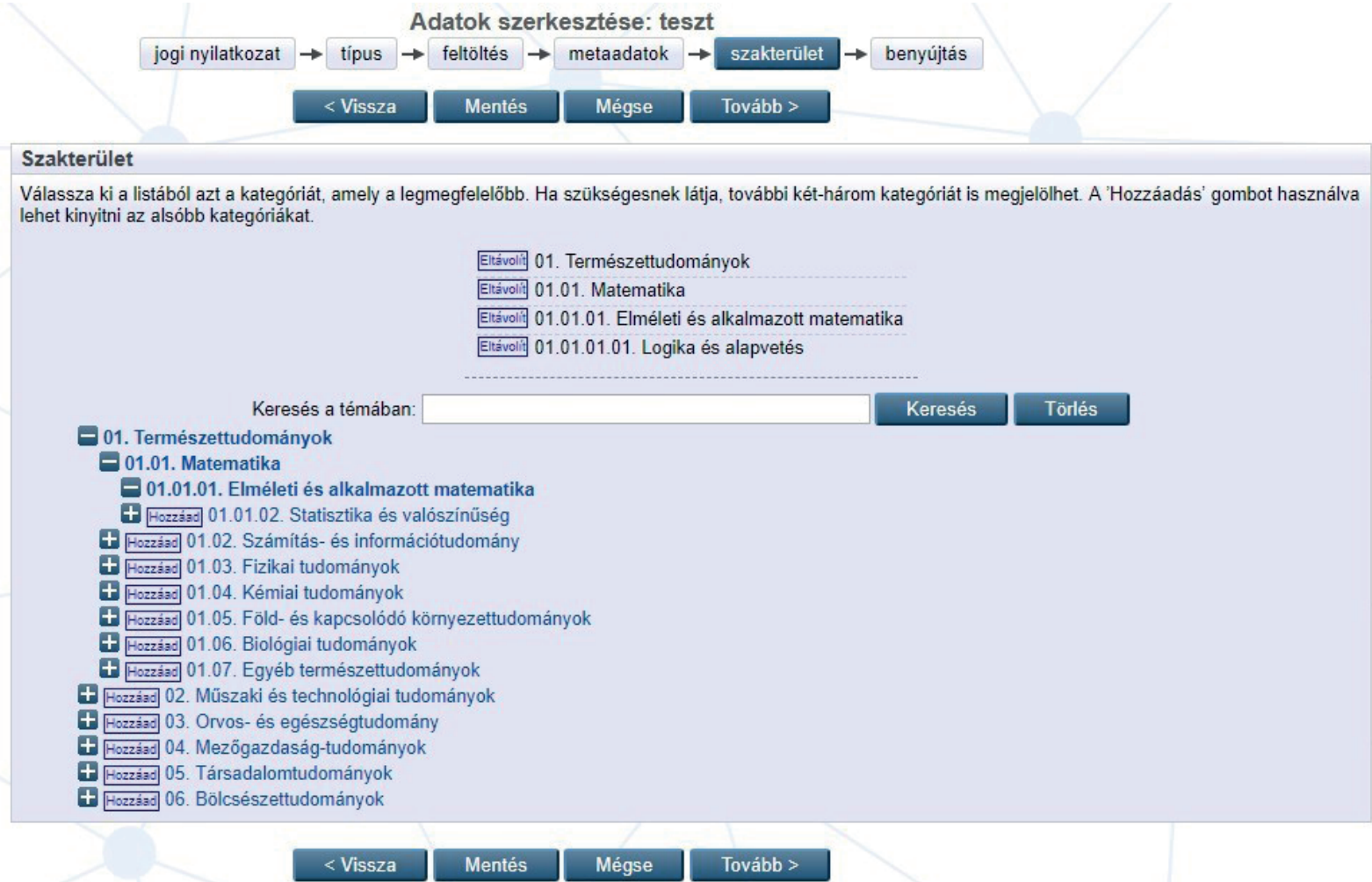

5. ábra - Szakterületek az EPrints szerkesztői felületén

Ezt a szakterületi besorolást jelenleg az SZTE Elektronikus Tananyag Archívumban használjuk, detervezzükbevezetniazSZTEPublicatioésazSZTEDoktorirepozitóriumokban is. 


\subsection{Omeka - Általános tulajdonságok}

Nemrégiben új intézményi kép- és médiaarchivum ${ }^{3}$ kialakitása vált szükségessé a korábbi MARC alapú képi nyilvántartásaink kiváltására. Erre a célra az Omeka Classic szoftvert választottuk, mely egy könyvtárak, múzeumok, levéltárak számára létrehozott nyiltt forráskódú program, amit 2007-töl fejleszt a Roy Rosenzweig Center for History and New Media intézet. A projekt támogatói között szerepel többek között a Library of Congress is ${ }^{4}$

A müködéshez szükséges környezet: Linux operációs rendszer; Apache HTTP szerver; MySQL adatbázis-kezelő; PHP szkriptnyelv és ImageMagick képszerkesztő ${ }^{5}$ Kezelöfelülete hasonlít az elterjedt tartalomkezelő rendszerekhez, mint pl. a WordPress, így viszonylag könnyen megtanulható a kezelése.

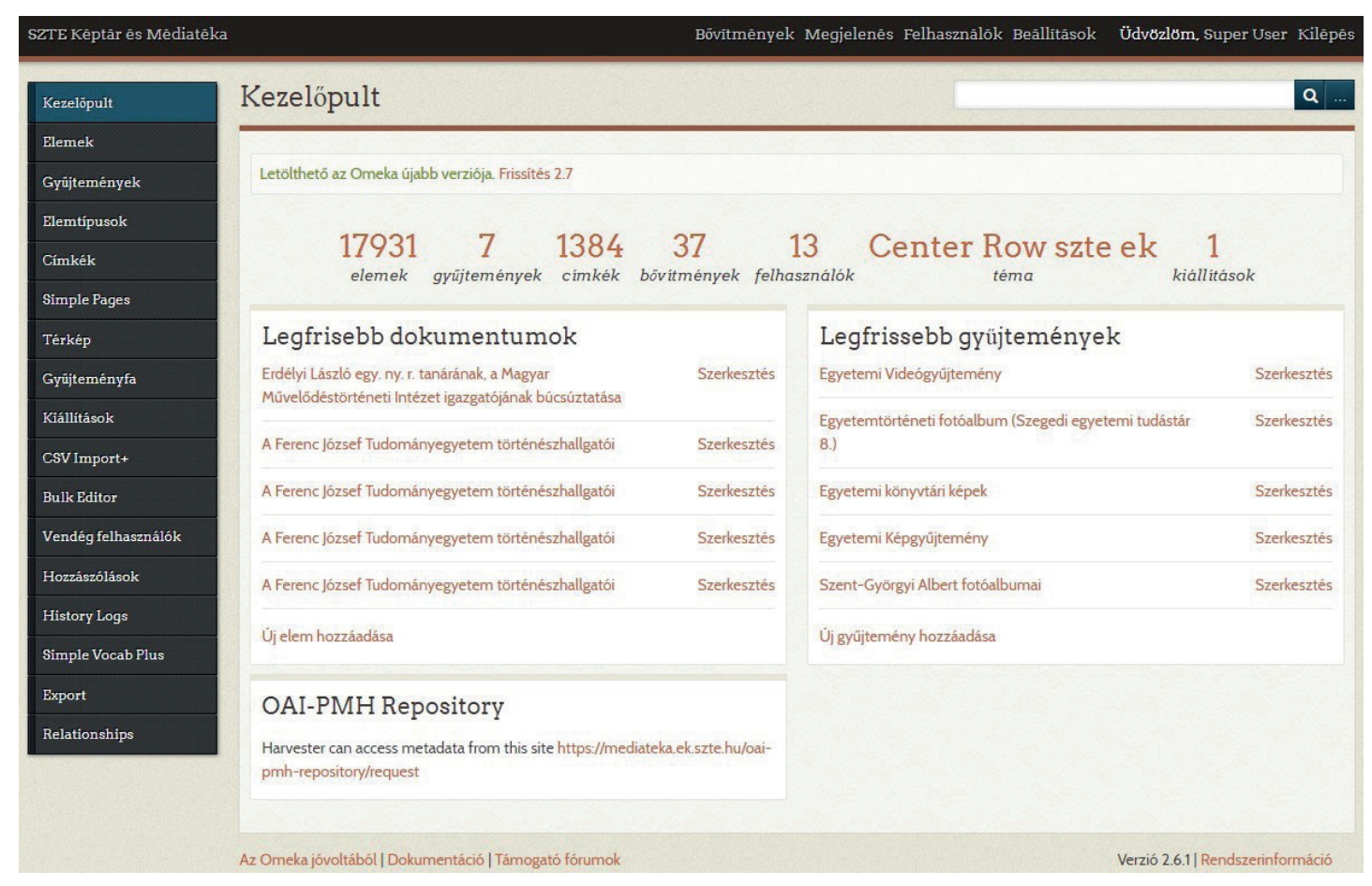

6. ábra - Az Omeka Classic adminisztrátori felülete

Az Omekát részben a részletes dokumentáció miatt választottuk, nem csak felhasználói ${ }^{6}$, de fejlesztői ${ }^{7}$ szempontból is jól dokumentált, valamint aktiv felhasználói közösség virágzik a hivatalos fórumon ${ }^{8}$. A közösségi segitséggel készült forditásokat a Transifex szolgáltatáson keresztül9 gyüjtik. Kollégáink segitségével

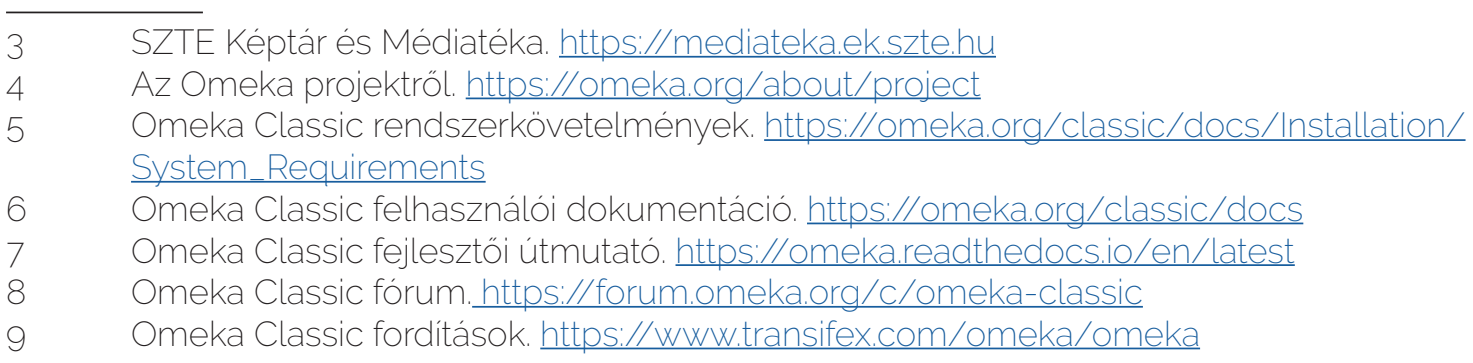


elkészitettük több bövitmény és az alaprendszer nagy részének magyar fordítását, amely elérhető a fent említett oldalon és bekerült az Omeka Classic legújabb 2.7es verziójába.

A sokrétü tartalomszolgáltatási funkcióknak köszönhetöen a szolgáltató intézmények igényeihez jól igazitható a rendszer. Használhatjuk a már elérhető témák egyikét ${ }^{10}$, de elkészithetjük saját, intézményi arculathoz igazodó megjelenésünket is. A különféle bővitmények segitségével térképen ábrázolhatjuk a rekordjainkat és virtuális kiállitásokat készithetünk belölük. Felhasználóinkat is bevonhatjuk a feldolgozás folyamatába, hozzászólások és egyéb közremüködések formájában. Mivel a rendszer képes többféle felhasználótípus kezelésére, alkalmas crowdsourcing projektek megvalósitására is.

A feltöltési folyamat többlépcsős, illetve egy elemhez több fájl is feltölthető. Első lépés a metaadatmezők kitöltése, majd az elem típusának meghatározása (kép, hanganyag, szöveg stb.). Ezután lehet feltölteni a fájlokat, címkéket hozzáadni és egyéb bővitmények nyújtotta lehetöségeket használni pl. térképen megjelölni a helyszint.

Egy elem lehet nyilvános vagy privát. Utóbbi nem jelenti feltétlenül azt, hogy a felhasználóktól teljesen elzárt lenne. Az Omeka Classicban alapból elérhető négy felhasználótipus egyike a 'Researcher' felhasználó, aki megtekintheti a nyilvános és zárt tartalmakat is, de semmilyen módon nem tudja azokat módositani. Vagyis megengedjük a felhasználóinknak, hogy regisztráljanak az oldalunkra, ahol adminisztrátori jóváhagyás után a kutatók hozzáférést kaphatnak a teljes gyüjteményhez. A további felhasználótipusok a következők: 'Super' (legmagasabb szintü jogosultság), 'Admin' (új elem feltöltése ès a már meglévő elemek szerkesztése, törlése), 'Contributor' (új elem feltöltése, ami csak ellenörzés után nyilvános). A Guest User bővitmény segitségével megadható egy ötödik típus, az úgynevezett 'Guest' felhasználó, amely szükséges más bővítmények müködéséhez (pl. Commenting).

Mivel az Omeka Dublin Core metaadat-struktúrát használ, a meglévő MARC rekordjainkat át kellett alakítani. Ehhez az ingyenes MarcEdit programot használtuk, amivel először egy CSV fájlba konvertáltuk az adatokat, majd a MARC mezőneveket helyettesítettük a megfelelő Dublin core adatelemre és az így elkészült metaadatokat és fájl elérési utat is tartalmazó CSV fájlt betöltöttük Omekába a CSV Import+ bővitmény segitségével ${ }^{11}$.

Bekerült az a jelentős képanyag is, melyek digitalizálása megtörtént az évek során, de még nem lettek egy rendszerben sem feldolgozva, így négy fö gyüjteményt alakitottunk ki: Egyetemi Arcképcsarnok; Egyetemi Képgyüjtemény; Shvoy Kálmán fotóalbumai; Szent-Györgyi Albert fotóalbumai (utóbbi három származik

10 Omeka Classic témák. https://omeka.org/classic/themes

11 Részletek: Nagy Gyula, Nagy Dóra, Sándor Ákos: Tömeges adatkonverzió és rugalmas export-import lehetőségek az EPrints, OJS és Omeka szoftverek körében 

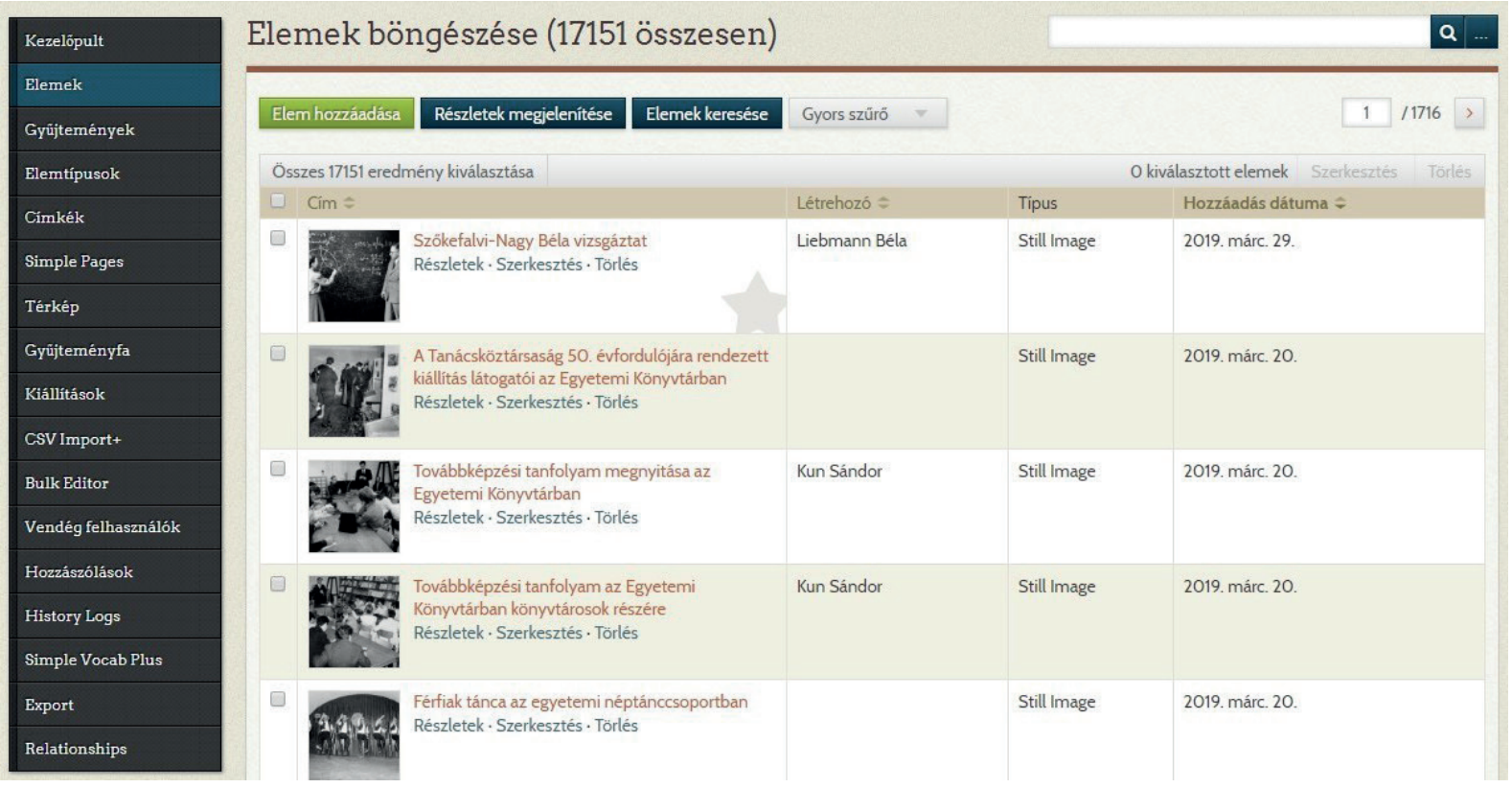

7. ábra - A betöltött elemek az adminisztrátori felületen

MARC adatbázisból). Utóbb létrehoztunk két algyüjteményt is az Egyetemi Képgyüjteményen belül: Egyetemi könyvtári képek és Egyetemtörténeti fotóalbum. A videófelvételek az Egyetemi videógyüjteményben találhatóak meg. Jelenleg is több, mint 16000 nyilvános és 1500 feldolgozásra váró elemet tartalmaz az adatbázis. A további gyarapodása folyamatos, az újonnan bekerülő és a meglévő papíralapú képanyag digitalizálása révén.

\subsection{Omeka - Bövítmények}

A hivatalos oldalon több, mint 90 bővítmény ${ }^{12}$ található, melyböl mi 21-et használunk, ezek közül sorolunk fel néhányat:

- A Dublin Core Extended bővitmény hozzáadja az összes Dublin Core metaadat mezőt a már meglévő alap 15 adatelemhez (pl. létrehozás dátuma).

- Az OpenStreetMap alapú Geolocation bővítmény használható az egyes elemek térképen való ábrázolására.

- A CSV Import+ bövitmény nemcsak metaadatokat és fájlokat, hanem egyéb adatelemeket pl. geokódokat is tud importálni. Többféle CSV struktúra áll rendelkezésre, melyek segitségével egy rekordhoz több fájl is betölthető egyszerre; utólagos nagy tömegü módosítás is végrehajtható, illetve az egész betöltés vissza is vonható.

- Az Exhibit Builder bövítménnyel lehet több aloldalt is tartalmazó virtuális kiállítást létrehozni, melynek akár a föoldaltól eltérö egyedi témát is készithetünk. Az Exhibit Image Annotation ezen belül a képen szereplö dolgok megjelölésére (tagelésére) alkalmas. 
- A Commenting bővitmény hozzászólási lehetőséget biztosit a felhasználóknak. A Guest User bövitménnyel együttmüködve egy olyan felhasználói típust hoz létre, amely csak hozzászólás írására képes, bejelentkezés és adminisztrátori jóváhagyás után. A Social Bookmarking bővitmény minden elemhez megosztás gombokat társit (pl. Facebook, Twitter). Mig a SimpleContactForm regisztráció nélküli üzenetküldésre használható.

Ezek mellett több bővitmény tesztelése zajlik, ilyen például az AvantRelationship, mellyel kapcsolati háló hozható létre az egyes elemek között. A Simple Vocab Plus bővitménnyel pedig ajánló tárgyszólista készithető. A tartalmi bővülést tekintve folyamatos a Szent-Györgyi Gyüjtemény feldolgozása, illetve további hagyatéki és egyetemi vonatkozású kép- és videóanyagok betöltése és feldolgozása. 


\title{
Tömeges adatkonverzió és rugalmas export-import lehetöségek az EPrints, OJS és Omeka szoftverek körében
}

\author{
Nagy Gyula \\ SZTE Klebelsberg Könyvtár \\ gyula.nagy@ek.szte.hu \\ ORCID: 0000-0002-8391-2851 \\ Nagy Dóra \\ SZTE Klebelsberg Könyvtár \\ dora.nagy@ek.szte.hu \\ Sándor Ákos \\ SZTE Informatikai és Szolgáltatási lgazgatóság \\ akos.sandor@ek.szte.hu
}

\begin{abstract}
Possibilities of massive data conversion and flexible processes of export-import regarding EPrints, OJS and Omeka software

Since we have been using different types of systems to provide our digital contents, we had to migrate our data several times over the years. The lesson to be learned is ensuring interoperability and data exchange between these systems is a constant priority for libraries. Uploading several records at a time have become common practice in our library by now.
\end{abstract}

Each year since 2012 thousands of degree theses have been received from Modulo, which is an online platform assisting students and staff of the University. We have to convert the original XML file to a structure which is compatible with our EPrints based repository. The handling of SZTE Repository of Papers and Books, Miscellanea and UnivHistória repositories follows a similar procedure, but with different initial conditions. Last year we have started to work with Open Journal System, therefore establishing an efficient data conversion method between EPrints and OJS and vice versa was necessary.

One of our long-term plans was to have a search engine which can discover all of our repositories and we were able to achieve this with the help of the Vufind, which is an open-source search engine especially for libraries. A critical point of the project was to develop a data exchange format for MARC using OAI-PMH in EPrints.

Our previous Marc-based databases (Bodza) were exported to EPrints years ago, and with that experience we were able to start building our new Omeka-based photo archive. In this presentation we demonstrate the above mentioned processes through a few practical examples.

Keywords: repository, data conversion, data import and export, bulk data import, EPrints, Open Journal System, Omeka, VuFind, MARC, OAI-PMH 


\section{Bevezetés}

Az SZTE Klebelsberg Könyvtár digitális tartalmainak szolgáltatása terén az évek során különféle szoftveres megoldásokat használtunk, így többször elöfordult, hogy az adatok migrálására volt szükség. Fontos tanulság, hogy a különbözö rendszerek közötti átjárhatóság és adatcsere biztositása folyamatosan kiemelt feladatként van jelen a könyvtárak munkájában. Ezen migrálások mellett mára bevett gyakorlattá vált az új rekordok tömeges adatbetöltése repozitóriumainkba, amely munkamenetnek mindig az adott archívum sajátosságaihoz kell illeszkednie. Többek között 2012 óta ilyen módon zajlik az évente több ezer kurrens szakdolgozat átvétele a Szegedi Tudományegyetem tanulmányi rendszeréböl. A hallgatók diplomamunkáikat a Modulo-ba töltik fel, amelyek a Neptunból származó, összefésült metaadatokkal együtt kerülnek exportálásra. Az így kapott XML fájlt EPrints XML formátumra (EP3 $X M L)$ szükséges konvertálni. Az adatkonverzió után történik a szakdolgozatok tömeges betöltése. Hasonló elvek mentén, de más kiinduló feltételekkel történik az SZTE Egyetemi Kiadványok, az SZTE Miscellanea, az SZTE UnivHistória és a Tiszatáj archivumának kurrens és retrospektiv gyarapítása is.

A tavalyi évben egy EFOP 3.6.3 projektnek köszönhetően elindult az SZTE OJS folyóirat-platform. A Szegedi Tudományegyetemhez köthető folyóiratok archivumának gyors kiépitése és a hatékony munkavégzés megteremtése miatt szükség volt az EPrints-OJS, majd a repozitóriumok gördülékeny gyarapításának biztositása miatt az OJS-EPrints automatizált konverziós irányok megteremtésére is. Az adatcsere egy másik megközelítését alkalmazva, repozitóriumaink speciális tagoltsága miatt régi tervünk volt ezek közös kereshetöségének biztositása, amelyet egy EFOP 3.4.3. projekt keretében a VuFind rendszer segítségével valósitottunk meg. A projekt kritikus eleme volt az EPrints OAI-PMH kimenetén elöállitott MARC formátumok adatcsere lehetőségének kidolgozása.

Az eddig emlitett szoftverek körében szerzett gyakorlat és korábbi MARC alapú adatbázisaink (pl. Bodza) tartalmának EPrints-be való átköltöztetése évekkel ezelőtt megtörtént, amely tapasztalatokat már fel tudtuk használni új, Omeka alapú képgyüjteményünk (SZTE Képtár és Médiatéka) létrehozásakor. Tanulmányunkban a fent emlitett projektek munkafolyamatai közül a legtanulságosabbakat kíséreljük meg bemutatni, elsösorban a tömeges adatkonverzió és a rugalmas export-import lehetőségek területéröl.

\section{Repozitóriumi metaadatbetöltési gyakorlat}

Érdekes volna alaposabban körüljárni a hazai (és nemzetközi) repozitóriumok gondozói által használt tömeges adatbetöltési gyakorlatot, hogy mely intézményi repozitóriumoknál számit bevett rutinnak a tömeges export-import lehetöségek kihasználása, illetve a legtöbb szabványos repozitóriumrendszer esetében rendelkezésre álló OAI-PMH protokoll által biztositott potenciál kiaknázásának jó példái is tanulságosak lennének. Sajnos erre jelen tanulmány keretében nincs módunk, helyette elsősorban saját, ilyen irányú megoldásainkról tudunk csak beszámolni. 
A metaadatok repozitóriumba való injektálásának egyik kézenfekvő módját jelentheti egy adott könyvtár OPAC-jából származó katalógusadatok repozitóriumi betöltése. Erre kiváló példaként szolgálaz MTA Könyvtár és Információs Központban az Aleph és az EPrints rendszerek közötti adatcsere kapcsolat megteremtése vagy az Országos Széchényi Könyvtár adatbázis konszolidációs projektje kapcsán alkalmazott megoldások¹. Egy másik kiválóan müködő példa lehet a metaadatok automatizált továbbitására az MTMT felöli, SWORD² protokollon át történő intézményi repozitóriumokba való adattovábbitás, ahol valójában nemcsak metaadatok utaznak a hálózaton keresztül, hanem a publikációk teljes szövegét tartalmazó fájlok is részei a továbbított csomagnak.

Saját tömeges adatbetöltési gyakorlatunk alapját a minél automatizáltabb megközelítés adja. Egyes repozitóriumok esetében már a kezdetektöl célul tüztük ki a teljes analitikus feldolgozást, amihez az egyes folyóiratokat, egyetemi actákat és tanulmányköteteket magától értetődő módon, fájlszinten is részekre kellett bontani. Ehhez a PDFtk ${ }^{3}$ nevezetü parancssori eszközt használjuk. Ennek szintaktikája és müködési módszere az 1 . ábrán látható.
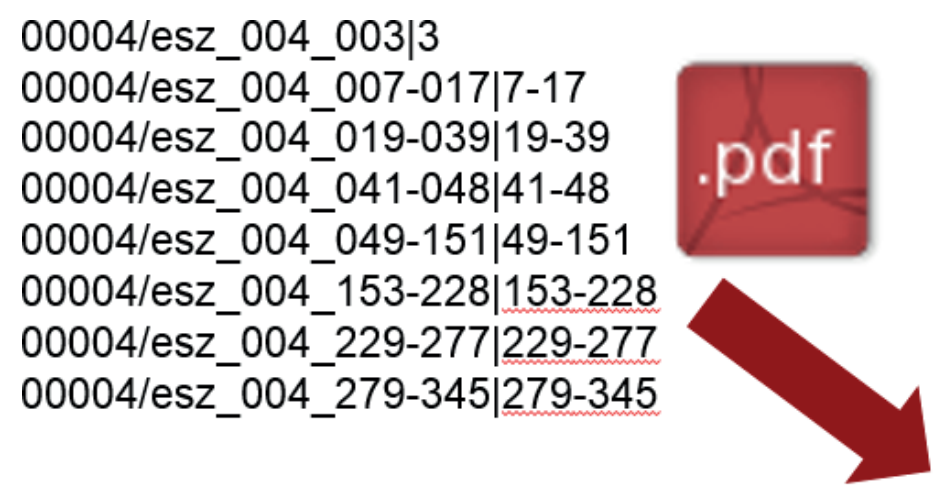

$>$ pdftk the pdf toolkit

pdftk esz_004.pdf cat 3 output esz_004_003.pdf

pdftk esz_004.pdf cat 7-17 output esz_004_007-017.pdf pdftk esz_004.pdf cat 19-39 output esz_004_019-039.pdf pdftk esz_004.pdf cat 49-151 output esz_004_049-151.pdf pdftk esz_004.pdf cat 153-228 output esz_004_153-228.pdf pdftk esz_004.pdf cat 229-277 output esz_004_229-277.pdf pdftk esz_004.pdf cat 279-345 output esz_004_279-345.pdf

1. ábra - A PDFtk segédprogram alkalmazása: a cikkek logikai és fizikai oldalhatárai és a parancssorban futtatható, kötegelt fájl szintaxisa

\footnotetext{
1 Balázs László. Adatbázis konszolidáció az OSZK-ban. Networkshop 2017. Debrecen, 2016.03.29.-2016.04.01. Hozzáférés: 2019.06.17. https://kifu.videotorium.hu/hu/recordings/12965/adatbazis-konszolidacio-az-oszk-ban

2 Allinson, Julie, Sebastien François, and Stuart Lewis. "SWORD: Simple Web-service offering repository deposit." (2008). Hozzáférés: 2019.06.17. http://scholarworks.csun.edu/handle/10211.3/118201

3 PDFtk - The PDF Toolkit. https://www.pdflabs.com/tools/pdftk-the-pdf-toolkit
} 
Az ilyen módon elöállított PDF fájlok alapját képezik a következö lépésnek, hiszen az akár több ezer soros fájllistából egy ugyanennyi soros XLS vagy CSV fájltállítunk előtt, ahol az egyes mezők fogják tartalmazni az egyes metaadat-elemeket. A módszer segítségével jó néhány adatelem tömegesen, illetve fél-automatikusan kitölthetö (pl. számozási adatok, típusra vonatkozó adatok, azonosítók, stb.). Mivel az analitikus feldolgozás mellett fontosnak tartjuk a boritótól-boritóig terjedő teljes kötetek repozitóriumi megörzését is, ezért ezek is bekerülnek egy, a cikkek metaadatait tartalmazó táblázathoz hasonló listába (a 2. ábrán piros karikával jelöltük a két megközelítés közötti különbségeket). A teljes lapszámokat és köteteket "full”, míg az egyes tanulmányokat, cikkeket „part” néven hivatkozzuk. Ezek az elnevezések tükröződnek a táblázatok elnevezésében, illetve a későbbi munkafolyamatokban keletkező különböző kimenetekben is.

A következő lépésben azilyen módon előállitott, akártöbb tízezersoros táblázatokból elö kell állitanunk az EPrints által az automatikus adatbetöltések esetében preferált EP3 XML fájlokat. Ez egy repozitóriumonként meghatározott XML-skeleton alapján történik, a "full” és a „part” táblázatok eltérő adatelemeit természetesen ez az XMLskeleton is követi. Az elkészitett XML-sémából az XMLBlueprint ${ }^{4}$, vagy újabban a saját fejlesztésű CSV2XML Python-alapú segédeszköz segítségével készülnek el az EP3 XML fájlok, amelyeket az EPrints importfelülete már fogadni tud. A betöltések során a teljes szövegü PDF-ek is automatikusan bekerülnek a rekordokba, melyet úgy oldunk meg, hogy a <documents> rész megfelelö <url> tag-jében egy általunk üzemeltetett Apache webszerveren elhelyezett, csak a betöltés idejéig élő URL címek találhatóak. Természetesen ehhez a megoldáshoz a repozitórium oldalán engedélyezni kell a web-import lehetőséget. Az itt röviden felvázolt módszert használjuk évek óta mind a kurrens, mind a retrospektiv betöltések és idönként a migrálások esetében is, melynek segitségével immár több százezer rekordot tettünk közzé különböző archívumainkban.

\begin{tabular}{|c|c|c|c|c|c|c|c|c|c|c|c|c|c|c|}
\hline & A & \multicolumn{2}{|r|}{ B } & \multicolumn{4}{|c|}{$\mathrm{c}$} & E & $\mathrm{F}$ & G & \multirow{2}{*}{$\begin{array}{c}H \\
8 \text { - isbn }\end{array}$} & \multirow{2}{*}{\multicolumn{3}{|c|}{9 - format 10 - security 11 - filename }} \\
\hline 1 & $1-$ type & \multicolumn{3}{|l|}{2 - title } & 3-dat & \multirow{2}{*}{\multicolumn{2}{|c|}{ 4-publication_full }} & \multicolumn{2}{|c|}{5 -volume 6 -number } & & & & & \\
\hline 2 & book & \multirow{2}{*}{\multicolumn{3}{|c|}{ Aetas - 33. évf. (2018) 1.sz. }} & 2018 & & & 33 & $1 \quad 0237-7934$ & & & full & & aetas_2018_001.pdf \\
\hline & book & & & 2.sz. & 2018 & & 33 & 2 & 0237-7934 & & & $\begin{array}{l}\text { public } \\
\text { public }\end{array}$ & aetas_2018_002.pdf \\
\hline & book & \multicolumn{3}{|c|}{ Aetas - 33. evf. (2018) 3.sz. } & 2018 & Aetas & & 33 & 3 & $0237-7934$ & & TUII & public & aetas_2018_003.pdf \\
\hline 5 & book & Aetas - 33 évf. & $(2018)$ & 4.sz. & 2018 & Aetas & & 33 & 4 & $0237-7934$ & & full & public & aetas_2018_004.pdf \\
\hline 6 & book & \multicolumn{4}{|c|}{ A Szegedi Alföldkutató Bizottság'1930 } & \multicolumn{3}{|c|}{ A Szegedi Alföldkutató Bizottság kö'1 } & & & & full & public & alfoldkutato_001_001 \\
\hline 7 & book & A Szegedi Alföl & Idkutató & Bizottság & $g 1928$ & A Szegedi Alföldku & itató $\mathrm{E}$ & Bizottság kö & & & & full & public & alfoldkutato_002_001 \\
\hline 8 & book & A Szegedi Alföl & Idkutató & Bizottság & g' 1928 & A Szegedi Alföldku & itató $\mathrm{E}$ & Bizottság kö & & & & full & public & alfoldkutato_002_002 \\
\hline 9 & book & A Szegedi Alföl & Idkutató & Bizottság & g'1928 & A Szegedi Alföldku & & Bizottság kổ & & & & full & public & alfoldkutato_002_003 \\
\hline 10 & book & A Szegedi Alföl & Idkutató & Bizottság & g'1928 & A Szegedi Alföldku & itató $\mathrm{E}$ & Bizottság kö́t & & & & full & public & alfoldkutato_002_004 \\
\hline 11 & book & A Szegedi Alföl & Idkutató & Bizottság & g1929 & A Szegedi Alföldku & itató $\mathrm{E}$ & Bizottság kö́t & & & & full & public & alfoldkutato_002_005 \\
\hline 12 & book & A Szegedi Alföl & Idkutató & Bizottság & g'1930 & A Szegedi Alföldku & itató $\mathrm{E}$ & Bizottság kö" & & & & full & public & alfoldkutato_002_007 \\
\hline 13 & book & A Szegedi Alföl & Idkutató & Bizottság & g'1930 & A Szegedi Alföldku & Itató $\mathrm{E}$ & Bizottság kö" & & & & full & public & alfoldkutato_002_008 \\
\hline 14 & book & A Szegedi Alföl & Idkutató & Bizottság & g'1931 & A Szegedi Alföldku & Itató $\mathrm{E}$ & Bizottság kö́s & & & & full & public & alfoldkutato_002_009 \\
\hline 15 & book & A Szegedi Alföl & Idkutató & Bizottság & $a^{\prime} 1928$ & A Szegedi Alföldkut & itató $\mathrm{E}$ & Bizottság kö́2 & & & & full & public & alfoldkutato 003002 \\
\hline & A & B & $c$ & & & $\mathrm{D}$ & & E $\quad F$ & & & $\mathrm{H}$ & $1 \quad 1$ & k & \\
\hline 1 & $1-$ type & 2 - title & 3-dat & 4 -public & lication & & & volume 6 - nu & umbec - page & gerange & issn & 9 - isbn $10-\mathrm{fc}$ & ormat 11 - secu & urity 12 - filename \\
\hline & article & feldolgozásra vár & 2018 & Belveuter & AE Tueridic & ionale & 30 & 4 & & & $34-5929$ & part & public & belvedere_2018_00 \\
\hline & article & feldolgozásra vár & 2018 & Belveder & re Meridic & & 30 & 4 & $19-39$ & & $84-5929$ & & public & belvedere_2018_00 \\
\hline & arricle & feldolgozásra vàr & 2018 & Belveder & & & 30 & 4 & $40-60$ & & & palt & public & belvedere_2018_00 \\
\hline 5 & article f & feldolgozásra vár & 2018 & Belveder & re Meridic & ionale & 30 & 4 & $61-82$ & & $44-5929$ & part & public & belvedere_2018_00 \\
\hline & article $f$ & feldolgozásra vàr & 2018 & Belveder & re Meridic & ionale & 30 & 4 & 83-95 & & 5929 & part & pub & belvedere_2018_00 \\
\hline & article & feldolgozásra vár & 2018 & Belveder & re Meridic & & 30 & 4 & & & $84-5929$ & part & public & belvedere_2018_00 \\
\hline 8 & article of & feldolgozásra vár & 2018 & Belveder & re Meridic & ionale & 30 & 4 & $108-123$ & & $84-5929$ & part & public & belvedere_2018_00 \\
\hline & article of & śra vár & 2018 & Belveder & re Meridic & ionale & 30 & 4 & $124-140$ & & $84-5929$ & part & public & belvedere_2018_00 \\
\hline 10 & article $f$ & feldolgozásra vár & 2018 & Belv & & ionale & 30 & 4 & & & 64-5929 & part & public & belvedere_2018_00 \\
\hline 11 & article & feldolgozásra vár & 2018 & Belveder & re Mer & ionale & 30 & 4 & $160-180$ & & 84-5929 & part & public & belvedere_2018_00 \\
\hline & article f & feldolgozásra vár & 2018 & Belveder & re Mer & ionale & 30 & 4 & & & $64-5929$ & part & public & belvedere_2018_00 \\
\hline & article $f$ & feldolgozásra vár & 2018 & & & & 30 & 4 & & & & & & \\
\hline 14 & article & feldolgozásra vár & 2018 & Belves & re Mer & ionale & 30 & 4 & & & 64-5929 & part & public & belvedere_2018_00 \\
\hline & article of & feldolqozásra vár & 2018 & Belveder & re Meridic & & 30 & 4 & $211-215$ & & 84-5929 & part & public & belvedere 201800 \\
\hline
\end{tabular}

2. ábra - A teljes és rész PDF-ek metaadatait tartalmazó táblázatok 


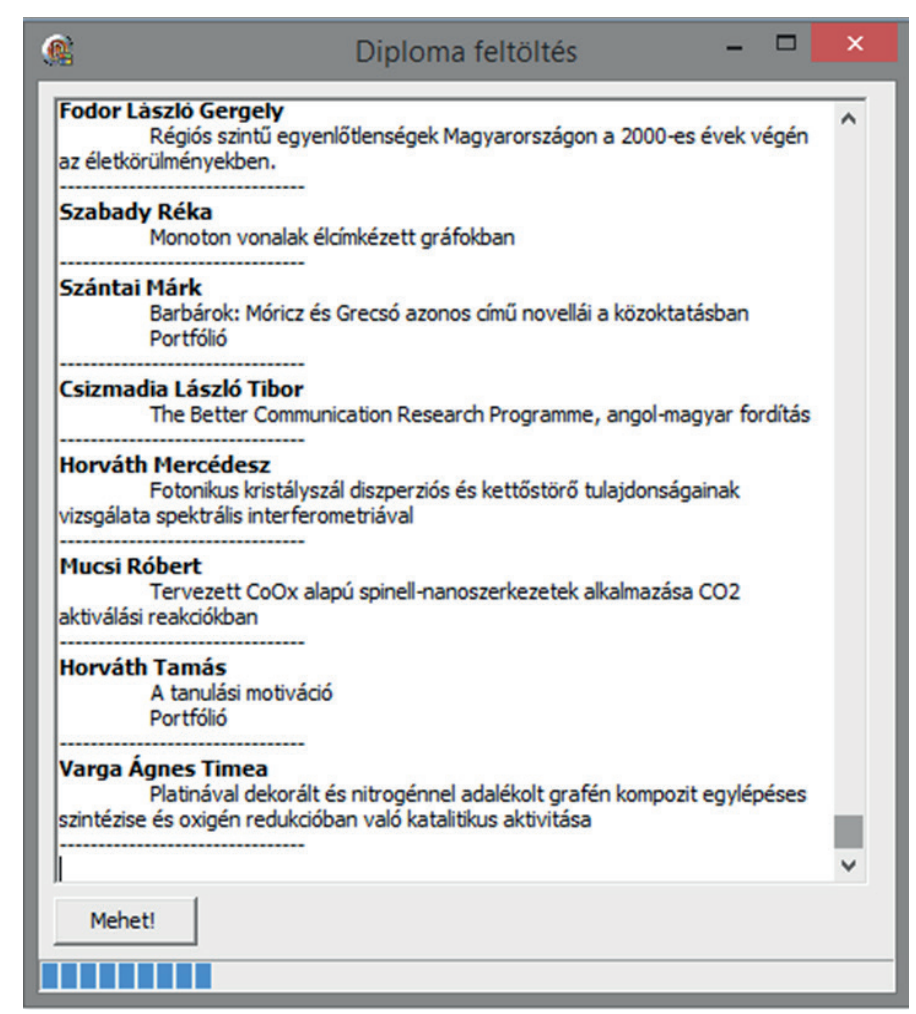

4. ábra - A szakdolgozatok metaadatainak konvertálása

\section{A repozitóriumok és az OJS közötti kétirányú adatkapcsolat megteremtése} Mivel a módszer bizonyitott, ezért a felmerült igények alapján elkezdtük kiterjeszteni más általunk használt szoftverekre is. A 2018-as év nyarán beinditott Open Journal System folyóirat-szerkesztőségi keretrendszer használatakor már kézenfekvő lehetőségként merült fel a fentiekben bemutatott módszeren keresztüli archívumépítés a platformra beköltöző 15 folyóirat mintegy 20 ezer körüli tanulmánya esetében. Ez a következö munkafolyamatot jelentette: EPrints EP3 XML export $\rightarrow$ EP3 XML táblázattá alakitása ${ }^{6} \rightarrow$ Manuális korrekciók $\rightarrow$ OJS nativ XML fájl elöállítása $\rightarrow$ OJS XML import.

A munkafolyamat kvázi megforditásával pedig az OJS platform alatt megjelenő kurrens lapszámok EPrints repozitórium alatti archiválásának folyamatos biztosítását tudjuk automatizálni: OJS DOAJ Export Plugin XML $\rightarrow$ XML fájl táblázattá alakitása 4 $\rightarrow$ Manuális korrekciók $\rightarrow$ EP3 XML fájl elöállitása $\rightarrow$ EPrints XML import.

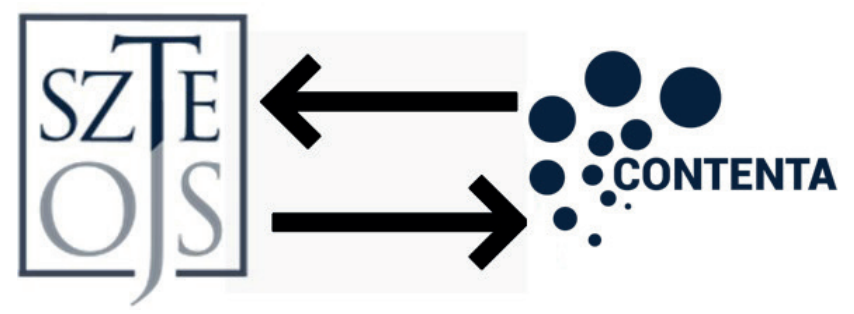

5. ábra - Az SZTE OJS folyóirat-platform és az SZTE Contenta rendszerek közötti kétirányú adatkapcsolat

6 Convert CSV/Excel To... http://www.convertcsv.com 


\section{Tömeges adatbetöltési lehetöségek az Omeka rendszer esetében}

A 2019-es év tavaszán elinditott SZTE Képtár és Médiatéka7 szolgáltatás alapjául az Omeka Classic ${ }^{8}$ nyilt forráskódú rendszert választottuk. Több tízezernyi fotónk metaadatai rendelkezésre álltak MARC formátumban, ezért mindenképpen meg kellett teremtenünk ezek Omekába való injektálásának lehetőségét. Mivel az Omeka rendszer CSVImport+ pluginja metaadatokat, fájlokat és geokódokat is tud importálni, továbbá egy rekordhoz több fájl is betölthető egyszerre, sőt akár az adatok csoportos módositására is lehetőség van, valamint az adminisztrátori felületen visszavonható a betöltés, így nagy rugalmasságot biztositottak ezek a funkciók. Ehhez "csupán” arra volt szükség, hogy a Bodza rendszerböl kiexportált MARC rekordokat a MarcEdit ingyenes szoftvercsomag9 segitségével - illetve a megfelelö MARC mezök és almezők Dublin Core megfeleltetésével - importkompatibilis, táblázatos formára alakitsuk. A kurrens, kötegelt betöltéseknél már eleve alkalmazható ez a táblázatos forma, hiszen az emlitett CSVImport+ plugin kiválóan fogadni tudja az igy betöltött rekordokat.

\begin{tabular}{|c|c|c|c|c|c|}
\hline Dublin Core:Identifer & Dublin Core:Creator & Dublin Core:Title & Dublin Core:Medium & Dublin Co Dublin Core & Dublin ODublin Core: Extent \\
\hline shvoy-001-001-001 & Shvoy Kálmán & Autótúra 1930. Ausztria, Németország (dél) & cimlap & 1930 p. 1. & $32,1 \times 24,5 \mathrm{~cm}(3702$ \\
\hline shvoy-001-003-000 & Shvoy Kálmán & 1. album, 3. oldal & oldalkép & 1930 p. 3. & $35 \times 26 \mathrm{~cm}(3816 \times 25$ \\
\hline shvoy-001-003-001 & Shvoy Kálmán & Aspang nyaralóhely & fénykép & 1930 p. 3. & $13 \times 8,1 \mathrm{~cm}(2656 \times 1 \mathrm{f}$ \\
\hline shvoy-001-003-002 & Shvoy Kálmán & Asspang nyaralóhely & fénykép & 1930 p. 3. & $13 \times 8,1 \mathrm{~cm}(2600 \times 1 \mathrm{t}$ \\
\hline shvoy-001-003-003 & Shvoy Kálmán & Aspang nyaralóhely & fénykép & 1930 p. 3. & $13 \times 8,2 \mathrm{~cm}(3420 \times 2$ \\
\hline shvoy-001-003-004 & Shvoy Kálmán & Asspang nyaralóhely & fénykép & 1930 p. 3. & $13 \times 8 \mathrm{~cm}(3368 \times 209$ \\
\hline shvoy-001-004-000 & Shvoy Kálmán & 1. album, 4 . oldal & oldalkép & 1930 p. 4. & $35 \times 26 \mathrm{~cm}(3264 \times 23$ \\
\hline shvoy-001-004-001 & Shvoy Kálmán & Alsó Aspang nyaralóhely & fénykép & 1930 p. 4. & $13 \times 8,1 \mathrm{~cm}(3444 \times 21$ \\
\hline shvoy-001-004-002 & Shvoy Kálmán & Kirchberg am Wechsel, Schneeberg & fénykép & 1930 p. 4. & $13,1 \times 7,8 \mathrm{~cm}(3198 \mathrm{x}$ \\
\hline shvoy-001-004-003 & Shvoy Kálmán & Kirchberg am Wechsel A. Ausztria & fénykép & 1930 p. 4. & $13,4 \times 8,6 \mathrm{~cm}(3231 \mathrm{x}$ \\
\hline shvoy-001-004-004 & Shvoy Kálmán & Kirchberg am Wechsel A. Austria & fénykép & 1930 p. 4. & $13,6 \times 8,7 \mathrm{~cm}(3260 \mathrm{x}$ \\
\hline shvoy-001-005-000 & Shvoy Kálmán & 1. album, 5. oldal & oldalkép & 1930 p. 5. & $35 \times 26 \mathrm{~cm}(3012 \times 22$ \\
\hline shvoy-001-005-001 & Shvoy Kálmán & Kirchberg am Wechsel & fénykép & 1930 p. 5. & $13,5 \times 8,6 \mathrm{~cm}(2890 \mathrm{x}$ \\
\hline shvoy-001-005-002 & Shvoy Kálmán & Kirchberg am Wechsel : Kilátás a Kernstockwar & fénykép & 1930 p. 5. & $13,5 \times 8,6 \mathrm{~cm}(1853 \mathrm{x}$ \\
\hline shvoy-001-005-003 & Shvoy Kálmán & Kirchberg am Wechsel : St. Wolfgang templom & fénykêp & 1930 p. 5. & $8,7 \times 13,5 \mathrm{~cm}(1470 \mathrm{x}$ \\
\hline shvoy-001-005-004 & Shvoy Kálmán & Kirchberg am Wechsel & fénykép & 1930 p. 5. & $13,8 \times 8,7 \mathrm{~cm}(3168 \mathrm{x}$ \\
\hline
\end{tabular}

6. ábra - Az Omeka rendszerbe szánt Dublin Core adatelemek táblázata

\section{A MARC formátum és az EPrints lehetséges kapcsolódási pontjai}

A támogatását vesztett Bodza keretrendszer kiváltása során szembekerültünk azzal a problémával, hogy nagy tömegü (összességében százezres nagyságrendü rekordszámról van szó) MARC rekordot kellett EP3 XML formátumra konvertálni. Szintén a Bodza alól való kiköltözés igényét erösítette a Java Applet támogatásának kivezetése a böngésző programokból, mivel így megszünt a Bodza MARC szerkesztői felülete. Néhány érintett adattárunk: SZTE Egyetemi Kiadványok, SZTE Miscellanea, SZTE UnivHistória, DélmagyArchív, Földrajzi Közlemények, Magyar Nyelvü Filozófiai Irodalom. A Bodzában tárolt nagy számú MARC21 alapú rekord konverziója EP3XML formátumra egy saját fejlesztésü Java alkalmazás segitségével történhetett meg.

\footnotetext{
7 SZTE Képtár és Médiatéka. https://mediateka.ek.szte.hu

8 Sirhán Bálint. Repozitóriumépités: válasszuk az Omeka open source rendszert! Tudományos és Müszaki Tájékoztatás 64. 12. sz. (2017) 619-622.

$9 \quad$ MarcEdit. https://marcedit.reeset.net
} 
100 \$a Tóth Sára

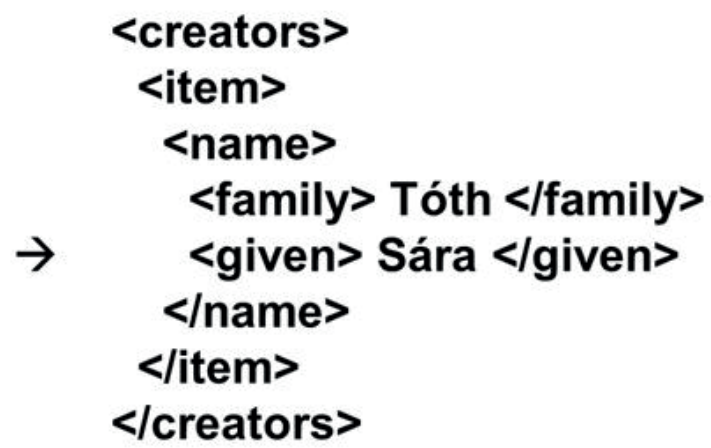

7. ábra - Egy kiragadott MARC-EP3 XML konverziós példa részlete

5. A repozitóriumok közös kereshetöségének megteremtése VuFind alapokon

A korábban alkalmazott Bodza-keretrendszer nemcsak metaadatokat és teljes szövegüállományokat szolgáltatott, hanem egyúttal több különálló adatforrás közös keresőjeként is müködött, amely funkció a Bodza kivezetésével ellátatlanul maradt, ugyanakkor érzékelhető módon erre a szolgáltatásra folyamatos igény mutatkozik a felhasználók részéröl. Ezért a korábban alkalmazott megoldást megkiséreltük kiváltani az EPrints repozitóriumaink VuFind alapú közös kereshetöségének biztositásával. A megfelelő szoftveres háttér kialakitásához az ötletet egy 2016-os Networkshop elöadás adta1. Informatikusaink különböző megfontolások miatt a MARC szabvány mellett tették le voksukat az adatcsere formátumát illetően, ezért már a kisérletezés elején megvizsgáltuk a GitHub-on megtalálható EPrints MARC export-import eszközt ${ }^{10}$. Sajnos ennek használata körül adódtak nehézségek, mivel egy több mint tíz éves kódról van szó, melyet az akkori EPrints verziókhoz fejlesztettek ${ }^{11}$. Ilyen nehézség volt például, hogy a megfelelő MARC mezőbe a rekord exportálásának időpontja íródott az eredeti létrehozási dátum helyett, illetve a tesztek során az OAl exportot követöen az Apache webszerver többször lefagyott. Az eszköz szerencsére parancssorból is müködöképesnek bizonyult, ami végül eredményre vezetett. Ütemezett feladatok segitségével így is biztositható a VuFind alapú közös kereső friss metaadatokkal való folyamatos ellátása.

\footnotetext{
10 EPrintsMARC. https://github.com/eprintsug/EPrintsMARC

11 Neugebauer, Tomasz, and Bin Han. Batch Ingesting into EPrints Digital Repository Software Information Technology and Libraries 31. 1. sz. (2012) 113-125
} 


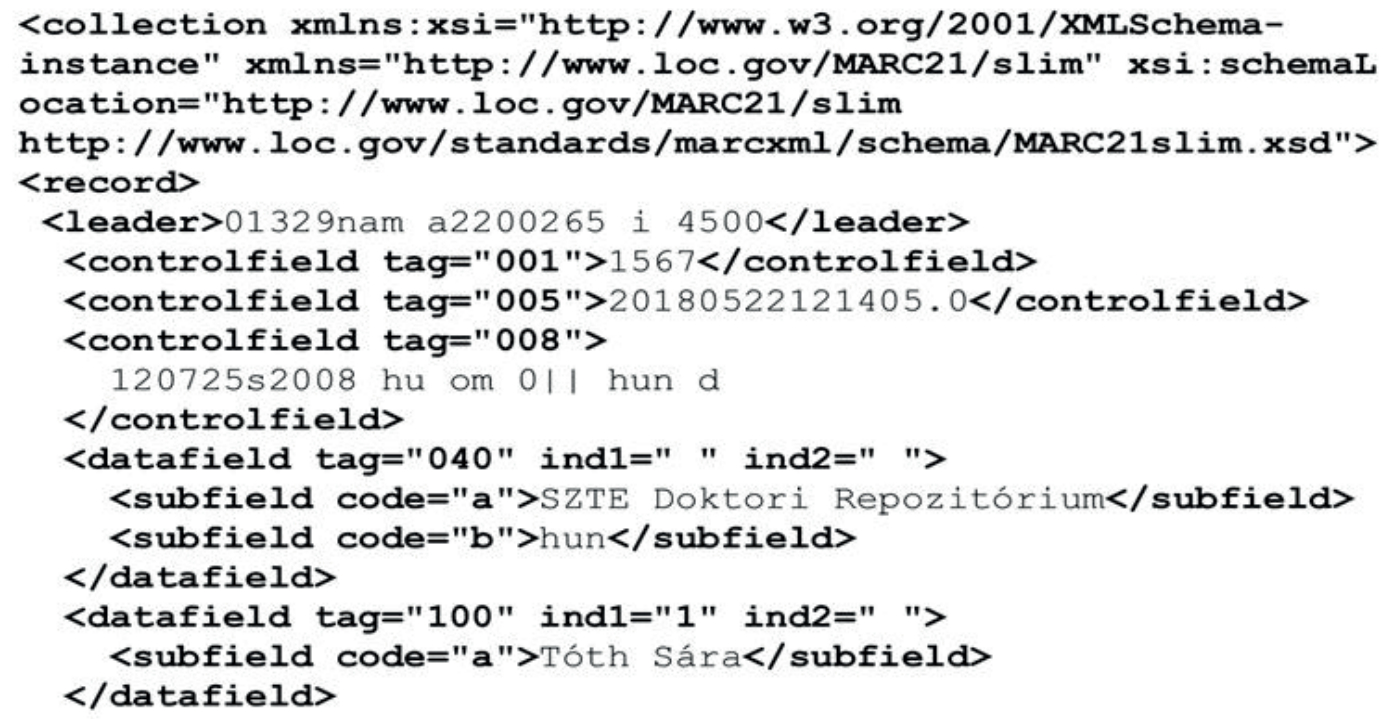

8. ábra - Az SZTE Doktori Repozitórium egyik rekordjából konvertált MARC XML egy részlete

Mivel célunk többféle adatforrásból egy közösen kereshető adathalmaz létrehozása volt, amely célkitüzés szinte magában hordozza a duplumok problémáját, ezért foglalkozni kellett az esetleges duplumrekordok kérdéskörének kezelésével is. Ezzel kapcsolatban szintén a GitHub-on találtunk megoldást a RecordManager nevezetü fejlesztés formájában ${ }^{12}$. Az algoritmus leírása és az ellenörzési szempontok részletesen megtalálhatóak a hivatkozott oldalon.

A VuFind alapú kereső létrehozásával a metaadatok közös kereshetőségének biztositása mellett természetesen a teljes szövegü indexelést is szerettük volna megoldani. Ezt különböző kiegészitő szoftverkomponensek segítségével lehet megvalósítani, az egyik ilyen például az Apache-projekt részét képező Tika elnevezésü megoldás ${ }^{13}$. A teljes szövegü kereséshez a Tika megfelelö telepítése és paraméterezése mellett a VuFind konfigurációs fájljaiban is el kellett végezni néhány beállitást.

\footnotetext{
12 RecordManager Deduplication https://github.com/NatLibFi/RecordManager/wiki/Deduplication

13 Apache Tika - a content analysis toolkit. http://tika.apache.org
} 
A Contentas névre hallgató közös kereső jelenleg tesztüzemben müködik, két repozitóriumunk (SZTE Doktori Repozitórium és SZTE Publicatio Repozitórium) teljes állománya található meg benne. A rendszer a http://contentas.bibl.u-szeged. hu URL címen keresztül nyilvánosan kipróbálható. Terveink szerint hamarosan a Contenta rendszer (amely jelenleg 12 független adattárból áll) tartalmának teljes egésze be fog kerülni.

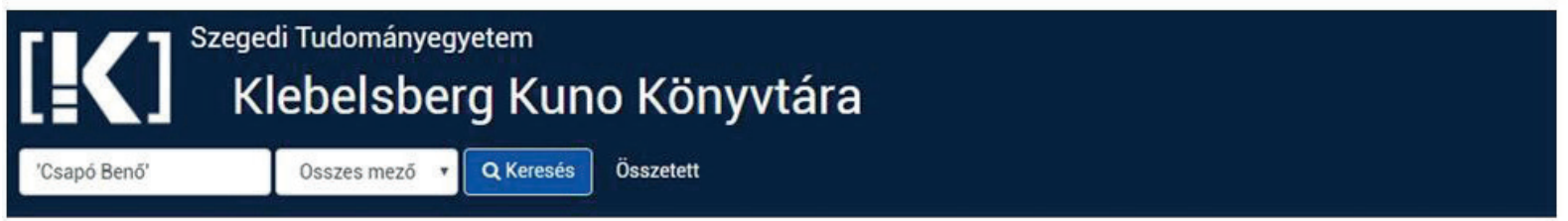

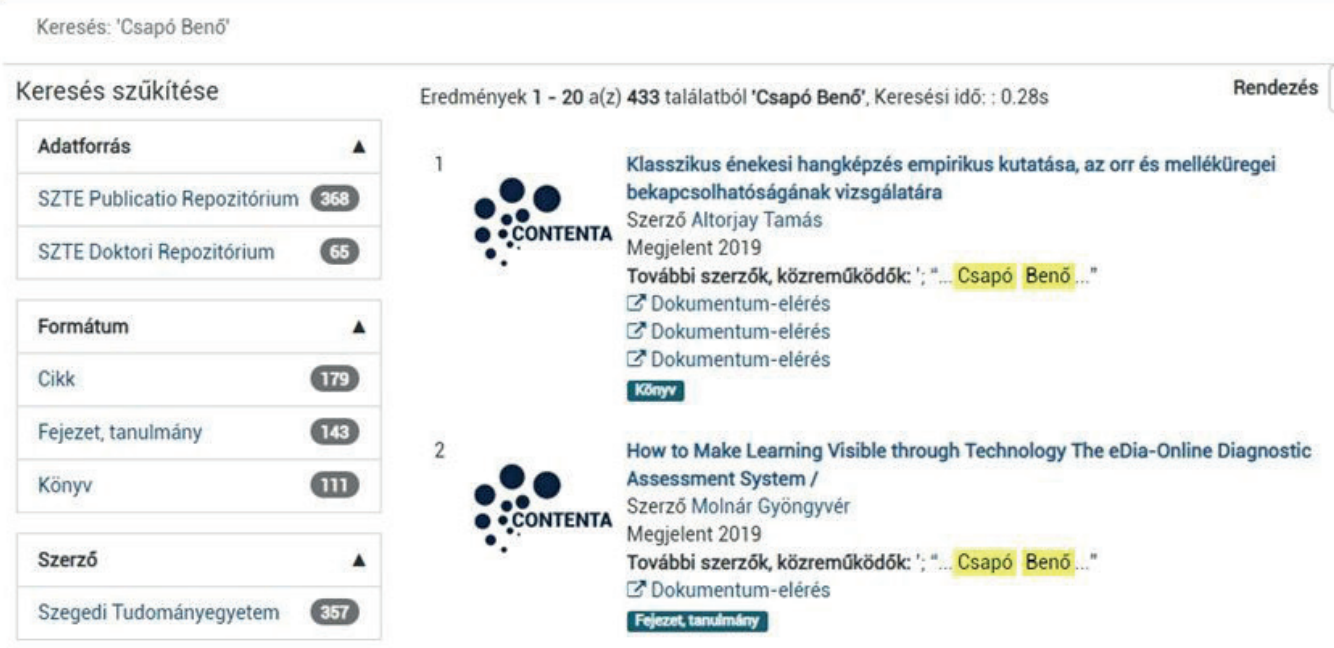

Eredmények 1 - 20 a(z) 433 találatbỏl 'Csapó Benố', Keresési idō: : $0.28 \mathrm{~s}$

Rendezés Dátum (csökkenō) v

9. ábra - Találati lista a VuFind alapú Contentas közös keresöben 


\title{
Magánvállalkozás és közszolgálat: A biográfiai index müfaji megújitása a Magyar Életrajzi Kalauzban
}

\author{
Németh Tibor \\ Kemenesaljai Müvelödési Központ és Könyvtár \\ mabi@cellkabel.hu
}

\begin{abstract}
Private company and public service : The renewal experiment of the genre of the biographical index in the Hungarian Biographical Guide. I summarise 34 years of experience in the light of the results: database of the 'Hungarian Biographical Guide' currently maintaining the data of 400,000 people. In 1985 I began to make catalogue cards of the data of people connected to my native land, Kemenesalja, and soon came across a lot of persons unknown for the locals. I have convictions that by broadening the coverage, it is worth proceeding to a comprehensive, a national registry. The creation of a representative national digital biography index seemed for a long time to be an impossible mission with work done during leisure time and without research background.

My experience entitles me to inspect the problem of the genre and the critical analysis of the initiatives. In my lecture I concentrate on the content elements and the conceptual relationships of this complex form. I scrutinise the loosely defined concept, then I analyze the novelties of the "Hungarian Biographical Guide" genre. I discuss the utilisation opportunities and finally, I supplement my study with personal remarks.
\end{abstract}

Keywords: Hungarian Biographical Guide, biography index, national digital database

\section{Bevezetés}

Elöadásomban megpróbálok vázlatos körképet adni a „Magyar Életrajzi Kalauz" reprezentativ nemzeti digitális névkataszter közel három és fél évtizedes történetéről, fejlödésének legfontosabb állomásairól, jelenlegi helyzetéröl illetve a jövő lehetséges forgatókönyveiröl ${ }^{1}$.

\footnotetext{
1 A részletek iránt érdeklődőknek: A biográfiai index müfajának megújítási kisérlete a Magyar Életrajzi Kalauzban. 1-2. rész. Könyvtári Figyelö, 27. (63.) 4. sz. (2017), 519-539 (http://ki2.oszk.hu/kf/2018/01/a-biografiai-index-mufajanak-megujitasi-kiserlete-a-magyareletrajzi-kalauzban/\#more-11291) (Hozzáférés: 2019. március 14.) + 28. (64.) 2. sz. (2018), 229245. (http://ki2.oszk.hu/kf/2018/07/a-biografiai-index-mufajanak-megujitasi-kiserlete-amagyar-eletrajzi-kalauzban-2/\#more-11658) (Hozzáférés: 2019. március 14.) További tájékozódáshoz javasolom egyetemi szakdolgozatomat: A biográfiai index, mint az életrajzi tájékoztatás integrativ müfaja, különös tekintettel a Magyar Életrajzi Kalauzra. Szombathely, 2014. 150 p. (http://cellbibl-digit.cellkabel.hu/nemeth_tibor-_biografiai_index.pdf) (Hozzáférés 2019. március 14.)
} 


\section{Elözmények}

Csöngéröl, egy kis kemenesaljai faluból származom, amely születésem elött fél évszázaddalegy másik könyvtáros gyermekkorának is helyszíne volt. Weöres Sándor azonban nem a bibliotékákban dolgozva alkotott maradandót, hanem a líra területén. 18 éves korom óta dolgozom a celldömölki könyvtárban „mezei” könyvtárosként és egy másik kemenesaljai híresség, Berzsenyi Dániel egyik munkájának címét citálva, az általam létrehozott névkataszter semmi másról, csupán a „mezei szorgalomrúl” szól... A nyolcvanas évek közepén a szerény számú lexikonokat lapozgattam a helyi személyeket gyüjtve és rengeteg helyben számon sem tartott érdekes emberre bukkantam. Úgy döntöttem, hogy módszeresen elkezdem kicédulázni a forrásokat immár a teljes körü feltárás igényével katalóguscédulákra, ahol minden adattípusnak meghatározott helye volt a kartonon.

\section{Müfaji dilemmák}

Már jócskán benne jártam az adatgyüjtésben, amikor elkezdett érdekelni, hogy mi lehet a müfaji meghatározása az általam lelkesen végzett munkának. Sikerült beazonositanom, hogy adattáram a legközelebb a biográfiai indexhez áll. Bizonytalanságom azonban nem tünt el, csak fokozódott, hiszen e tájékoztatási formának eléggé pongyola definiciója létezik, amely egzakt módon nem rögzíti, csupán körülírja a feltárandó adattípusokat. A minimálisan szükséges 4-6 alapadat azonban jóval kevesebb volt az általam alkalmazott 16 féle szempontnál, másrészt jelentösebb adattömeg esetén - mint majd látni fogjuk - már a beazonositást sem teszi egyértelmüen lehetővé.

Az alap szempontok áttekintése után nézzük meg, hogy mit jelentenek az elvek a gyakorlatban. A müfaj nemzetközi reprezentánsa, a World Biographical Index nem tartalmaz születési helyet, a születési és halálozási dátumnál a MEK napi pontosságú regisztrációjátóleltérően csakazévetadja meg. A puritánalapfilozófiából adódóan a születési hely mellett figyelmen kivül hagy olyan, a Magyar Életrajzi Kalauzban feltárt adattípusokat, mint az álnevek, adateltérések, kitüntetések és egyéb (kiegészitö) adatok. Az összehasonlításból nem túl merész következtetések vonhatók le a két adatbank információs potenciáljára vonatkozóan...

\section{Az adatrögzités eredményei}

A cédulákon lévő anyag retrospektiv számítógépes rögzitése 1994-ben kezdödött el, miután a Lakitelek Alapítvány támogatása jóvoltából sikerült vásárolnom egy akkoriban korszerünek számító számítógépet. Az előkészitett tételek ütemes feldolgozásával dinamikusan növekedett a rekordszám. Az ezredfordulón meghaladta a 100.000-es határt és a legfontosabb, ún. magforrások CD-n is hozzáférhetővé váltak. Napi könyvtárosi munkám mellett szabadidőmben reggel és este, hétvégén, szabadságom alatt otthon végeztem az adatgyüjtést és rögzitést 2003-tól kezdődően már online, azonnal hozzáférhető formában. 2019 januárjában sikerült átlépnem a 400.000 rekordot. 


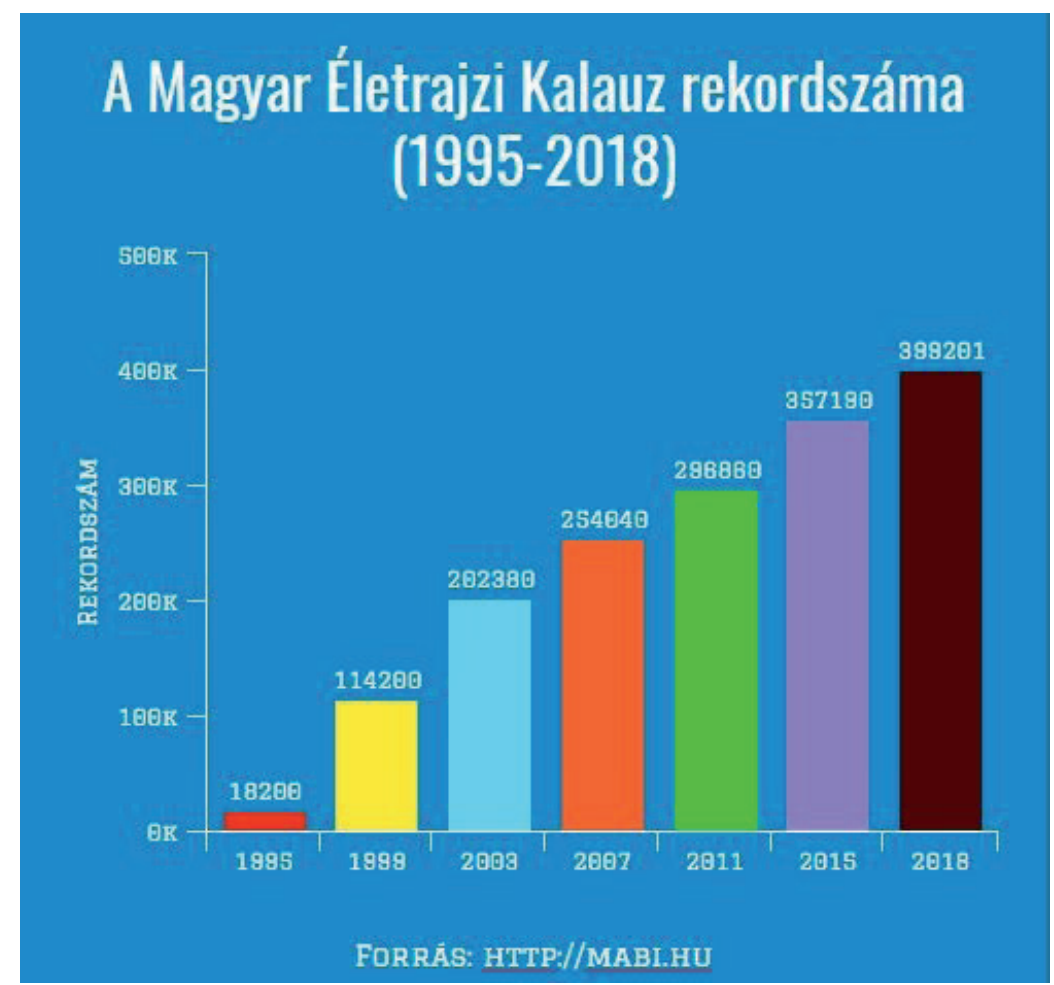

1. kép: A Magyar Életrajzi Kalauz rekordszáma (1995-2018)

Az eredmények elérésében Ösze László informatikus segitette a kezdetektöl munkámat illetve az internetes hozzáférést a Cellkábel nevü helyi kábelszolgáltató cég téritésmentesen bocsátotta rendelkezésemre, ezzel támogatva a nemzeti névkataszter fejlesztését.

A „Magyar Életrajzi Kalauz” feltöltöttségi áttekintését 400.000 rekord elérésekor bemutató táblázat léte már önmagában kuriózumnak számit a számitógépes adatbázisok világában. A fejlesztők ilyen transzparens módon nem szokták közzétenni az egyes adatmezök teljességét vagy egy rekordra vonatkozó tételátlagát. Bőven lehetne elemezni az adatsorokat, amelyek közül kettőre hívom fel a figyelmet. A születési helyek között több mint 16000 települést tartunk nyilván, ami elképesztő szám akkor is, ha rendszerünk nem csak a mindenkori Magyarországon születetteket, hanem a világon bárhol megtalálható magyar származásúakat is gyüjtőkörébe tartozónak érzi. A hivatkozások vonatkozásában az élő hivatkozások számát jelentősen, mintavételeink alapján 20-25\%-kal meghaladja a valaha feldolgozott forrásoké, mert az időszakonként frissitett segédanyagok tekintetében mindig csak az aktuális, legújabb kiadást adjuk meg, amely elvileg magában foglalja az előzményeket is. 


\begin{tabular}{|c|c|c|c|}
\hline $\begin{array}{l}\text { Keresési szempont } \\
\text { (mezőnév) }\end{array}$ & $\begin{array}{c}\text { Törzs file } \\
\text { (témák száma) }\end{array}$ & $\begin{array}{c}\text { Feltöltöttség } \\
\text { (összes rögzítés) }\end{array}$ & $\begin{array}{c}\text { Teljesség } \\
\text { (\% vagy tételátlag) }\end{array}$ \\
\hline Szül. hely (megye) & 177 & 296992 & $74,24 \%$ \\
\hline Suilletési helység & 16033 & 296762 & $74,19 \%$ \\
\hline Mük. hely (megye) & 144 & 61761 & $15,44 \%$ \\
\hline IyIúkkởlési helység & 8070 & 58486 & $14,62 \%$ \\
\hline Foglalkozás & 978 & 434867 & 1,0871 \\
\hline 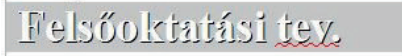 & 9 & 18493 & $4,62 \%$ \\
\hline Tudományos fokozat & 56 & 17505 & $4,37 \%$ \\
\hline Alsidémini trygry & 5 & 2523 & $0,63 \%$ \\
\hline Kitüntetés & 1692 & 44490 & $11,12 \%$ \\
\hline Néyvâlltorist & 96832 & 96832 & $24,20 \%$ \\
\hline Álnév & 9543 & 9543 & $2,38 \%$ \\
\hline Adigteltérés & 28382 & 33506 & $8,37 \%$ \\
\hline Egyéb adat & 17992 & 154198 & $38,54 \%$ \\
\hline Flivatloutís & 796 & 734839 & 1.8370 \\
\hline
\end{tabular}

2. kép: A Magyar Életrajzi Kalauz átvilágítása (2019.01.29.)

\section{A "Magyar Életrajzi Kalauz" hat müfaji újdonsága}

Az összegző táblázat rávilágít a "Magyar Életrajzi Kalauz" első műfaji újdonságára, ami az adattípusok széles terjedelmét és sokszinűségét jelenti. Második müfaji nóvumként jelenik meg a nemzeti digitális névkataszter átláthatósága és feltöltöttségének dokumentálása.

A transzparencia kérdésköre átvezet a forrásanalízis kulcskérdéséhez: ki kerülhet be az adattárba az egyes forrásokból? Adatfelvételi filozófiánknak megfelelően a forrásokba felvett személyek esetében további szelekciós technikát nem alkalmazunk. Ez az a harmadik múfaji újdonság, amellyel minden eddigi hasonló jellegü kezdeményezéstöl markánsan különbözik adatbankunk. Keresési metódusunk során egyértelmüen jelezzük, hogy egy adott forrásból hány személy került feldolgozásra. Két külön analitikus mellékadattárat is épitünk: MÉKSAJT elnevezéssel 2001. január 1-töl napilapok alapján végezzük a halálozások és a kitüntetések karbantartását, a MÉKADAT pedig 2007. január 1-töl az internet monitorozásával ugyanezeket az adattípusokat aktualizáljuk.

A sok müfaji újdonság mellett a legfontosabb alapelv: meggyöződésünk, hogy nincs jogunk felülbirálni az adott müvet összeállítók szakmai kompetenciáját. Az életrajzi dokumentációs vagyont feltáró tevékenységünkkel megpróbáljuk az önálló szócikkel vagy adatsorral rendelkező személyeket teljességgel beépiteni adatbázisunkba.

Az analitikus feltárás mélységének hasznosságára egyetlen példa: ha egy Nagy Ilona névváltozattal rendelkező illetőt kell beazonositanunk, akkor jelenleg rendszerünkben 41 ilyen személyt találunk. A névváltozat adatmezöben láthatjuk, hogy közülük öten is 1950-ben születtek. A hónapra / napra történő preciz feltárás 
Németh Tibor: Magánvállalkozás és közszolgálat: A biográfiai index múfaji megújitása a Magyar Életrajzi Kalauzban

nélkül vajon megkülönböztethetök lennének? A negyedik müfaji újdonságunk: az egyes adattípusokon belül mindig le kell hatolni a legkisebb azonositható egységig.

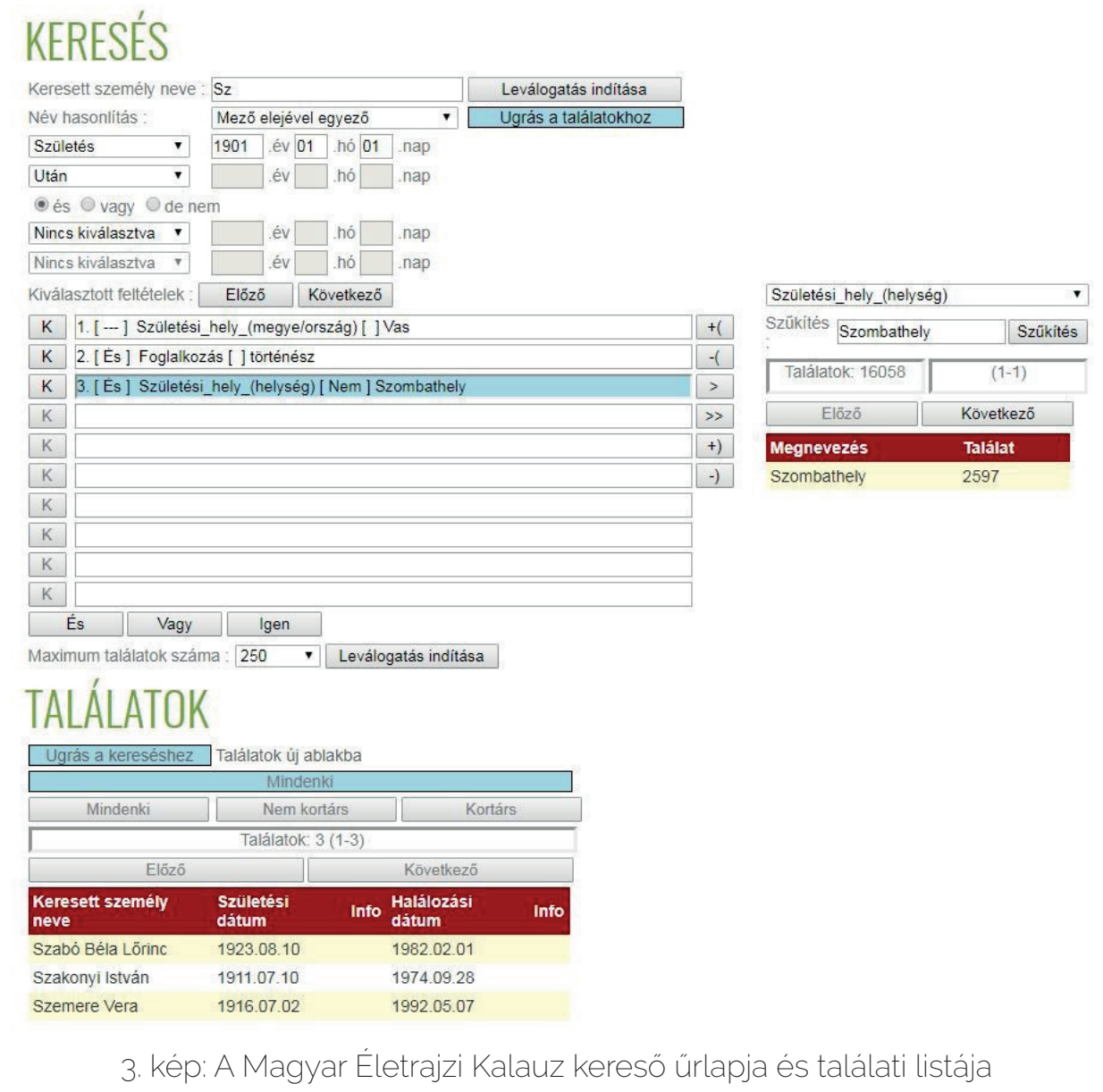

A hatékony visszakeresésre szolgál bizonyitékként az a példa, amelyben „Sz" betüvel kezdődő nevű személyeket keresünk, akik a XX. században, azaz 1901. január 1. után születettek Vas megyében, de nem Szombathelyen és történész volt a foglalkozásuk.

Nem túl bonyolult a minta, de nehéz lenne pár másodperc alatt megtalálni azt a 3 személyt, akit rendszerünk a feltételeknek megfelelően lekeresett. A Boole-algebra hatékony alkalmazása mellett érdemes felfigyelni arra, hogy a keresési stratégia kiválasztásának megkönnyitése érdekében olyan megjelenitést alkalmazunk, amelyben az adott ismérv mellett megtalálható a hozzá tartozó személyek folyamatosan aktualizált száma. Ezzel olyan komplex keresési teret nyitunk meg, amely variabilitásával és rugalmasságával a tematikus keresörendszerek között rendszerünk ötödik müfaji újdonságát jelenti.

Nem a fö csapásirányt jelenti a feltárás során, de ha az adott személynél olyan érdekes tényre bukkanunk, amelynek visszakereshetőségét fontosnak érezzük, akkor az egyéb adat kategóriában hozzáférhetővé tesszük. Ennek klasszikus megjelenési formája, ha valaki valamiben az első magyar volt. Jelenleg 264 ilyen megjelölés szerepel adattárunkban s talán ez az adatbányászati gyöngyszem jól jelzi, hogy mennyire nem végezhető mechanikusan az adatok rögzitése. 
Látványosan tükrözi rendszerünk hatodik müfaji újdonságát a foglalkozások hierarchikus rendszerének összehasonlító táblázata a World Biographical Index és a Magyar Életrajzi Kalauz között. Ég és föld a különbség a magyar adattár javára a sport kategória feltártságában. Adatbankunk saját fejlesztésü, rugalmasan hierarchizált foglalkozási tárgyszórendszert használ, amely hatékonyan segíti a használót a tematikus keresések megtervezésében. Az indokolt esetben többes besorolásoknak lehetnek vitatható elemei, de ezek eltörpülnek a rendszer alkalmazásának gyakorlati előnyei mellett.

\begin{tabular}{|c|c|c|}
\hline \multicolumn{2}{|c|}{ [D EART (600) } & 990320 \\
\hline 田 & EMusicians (610) & 262730 \\
\hline I & Composers (611) & 65393 \\
\hline$\square$ & Conductors, Musical Drectors (612) & 30534 \\
\hline$\nabla$ & Instrumentaists, Orchestral Musicians (613) & 68701 \\
\hline 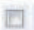 & Singers (614) & 62344 \\
\hline a & EPentorming Antsts (620) & 161456 \\
\hline$\nabla$ & Stage Managers, Directors (621) & 22111 \\
\hline T & Actors (622) & 110179 \\
\hline D & Dancers (623) & 11683 \\
\hline T & Other Stape Occupations (624) & 10040 \\
\hline (] & EPlastc Avtsts (630) & 666134 \\
\hline D & Painters, Draughtsmen, Graphic Avtists (631) & 361736 \\
\hline 圆 & Sculptors, Carvers, Founders, Modelers (632) & 83327 \\
\hline ] & Book Avtists and Calligraphers (633) & 19330 \\
\hline D & Handicraft Artsts (634) & 71591 \\
\hline 目 & Photographers (636) & 9091 \\
\hline \multicolumn{2}{|c|}{ GIFILM, RADIO AND TELEVISION (650) } & 48610 \\
\hline \multicolumn{2}{|c|}{ DERELIGION (700) } & 843811 \\
\hline 四 & Echristian and Jewish Religion (702) & 801738 \\
\hline$\theta$ & Theoiogians, Scholars of Religion (705) & 60231 \\
\hline$\theta$ & Priests, Preachers, Ministers, Rabois (710) & 389492 \\
\hline & Church Digntanes, Representatives, Acministrators (715) & 150450 \\
\hline 7 & Members of a Religious Order (720) & 163288 \\
\hline & Saints, Martyrs (724) & 14172 \\
\hline & Christian and Jemsh Religion. Others (725) & 24105 \\
\hline a & Dislamic Ecclesiastics (730) & 33539 \\
\hline$=$ & DHindu Religion (740) & 246 \\
\hline & DBudahist Religion (750) & 8052 \\
\hline 甲 & ШOther Religions (790) & 237 \\
\hline & PORTS AND LEISURE (800) & 86787 \\
\hline & Sportsmen (801) & 66550 \\
\hline & Toreros (810) & 5212 \\
\hline & Coaches, Managers (815) & 6382 \\
\hline & Sports Others (820) & 8643 \\
\hline
\end{tabular}

\begin{tabular}{|c|c|}
\hline SPORT & 6.10.9. OKōtvivó \\
\hline 61. Atlets & 6.10.10. Szzumózó \\
\hline 6.1.1. DOBÓATLELA & 6.10.11. Tekvandózo \\
\hline 6.1.1.1. Diszkoszietó & 6.10.12. Vivo \\
\hline 6.1.1.2. Gerelyhajito & 610.12 .1$. Kardvíto \\
\hline 6.1.1.3. Kalapácsvetó & 6.10.122. Pastbajtôrvivo \\
\hline 6.1.1.4. Sulylakó & 6.10.123. Tónivo \\
\hline 612 Gyaloglo & 610.12 Zen Bu Kan Kempe \\
\hline 613. Harominusazo & harcmives \\
\hline 6.14. Hetprobizo & 6.11. LABDAJÁTÉKOK \\
\hline 6.15. Kalapäcsvetô & 611.1. Asztaliteniszezó \\
\hline 61.6 Otprobazo & 611.2 Baliardozo \\
\hline 6.1.7. Súlyökó & 6.11.3. Fallabché \\
\hline 6.1.8. Tizprobazó & 6114. Floortallozo \\
\hline 6.19 UGROATLETA & 6.11.5. Golfozo \\
\hline 6.19.1. Hàmasugé & 6.11.6. Gyeplabdizzo \\
\hline 6.192 Magasugro & 6.11.7. Kezilabdizzo \\
\hline 6.19.3. Rnduger & 6.11.8. Kosarlabdizzo \\
\hline 6.19.4. Távolugró & 6.11.9. Labdanige \\
\hline 6.2 Edzó & 6.11.10. Labteniszezb \\
\hline 63. Eróspontolo & 6.11.11. Lovaspolozo \\
\hline 6.3.1. Súlyemeló & 6.11.12 Rögbijatekos \\
\hline 632 Testípito & 611.13 Roplabdizo \\
\hline 6.4. GEPIARMUSPPORT & 6.11.14. Teniszezo \\
\hline 6.4.1. Autómodellezó & 6.11.15. Totlaslabdizé \\
\hline 6.42. Autósversenyzó & 6.11.16. Vizilabdieo \\
\hline 6.43. Gokartversenyzö & 6.12. LOVASSPORT \\
\hline 6.44. Kerekparversenyzó & 6.121 Dilowaglo \\
\hline 6.4.5. Motorcsonalkversenyzó & 6.12.2 Dijugrato \\
\hline 64.6. Motorkerdiparversenyzò & 6.123. Fogathajto \\
\hline 65. GMNASZTIKA & 6.12.4. Lovas \\
\hline 65.1. Aerobicversenyzô & 612.5. Lovaspotózó \\
\hline 6.5.2. Fitmessversenyzo & 6.12.6. Lovastornasz \\
\hline 6.5.3. Kôtelugró & 6.127. Lovastusizo \\
\hline 6.54 Muivesai tomász & 6.13. LOVESTET \\
\hline 6.5.5. Spertakrobata & 6.13.1. 1yasz \\
\hline 6.5.6. Tomisz & 6.13.1.1 Szamszerijasz \\
\hline 657 Versenytincos & 6132 Stovó \\
\hline 6.6. GORSPORT & 6.13.3. Sportlowó \\
\hline 6.6.1. Gorkorcsolyazzó & 6.14. Masszer \\
\hline 6.7. Jatedkezetó & 6.15. MODELLEZÖSPORT \\
\hline 6.8. KARTYAJATEK & 6.15.1. Automodellezö \\
\hline 6.8.1. Bnidesezo & 6.15.2 Hajomodellezó \\
\hline 6.82. Trokktozo & 6.153 Rúdiómodellezô \\
\hline 69. Kerchpinversenyzo & 6.16. Sportorvos \\
\hline 69.1. Mototkerchparvenyzô & 6.17. Sporttö́tenész \\
\hline 69.2. Salakmotorikerélipiros & 6.18. Sportuijsagiró \\
\hline 610. KUZZDÓSPORT & 6.19. Sportvezetó \\
\hline 6.10.1. Auladós & 6.20. TABLAJATEK \\
\hline 6.10 .2 Birkózó & 620.1 Damsversenyzo \\
\hline 6 10.3. Bo jitsul kai versenyzó & 6.20 .2 Salkkozo \\
\hline 6.10.4. Cselgancsozo & 6.20.2.1. Hexasaldsozo \\
\hline 6.105. Karetézó & 62022 \\
\hline 6.10 .6 Kendozó & Saldfeladvajnyszerzó \\
\hline 6.10.7. Kidtbokszoló & 6.21. TEKEJÁTEK \\
\hline 6108 Kung-flazo & 6.21.1. Bocsaversenyzo \\
\hline
\end{tabular}

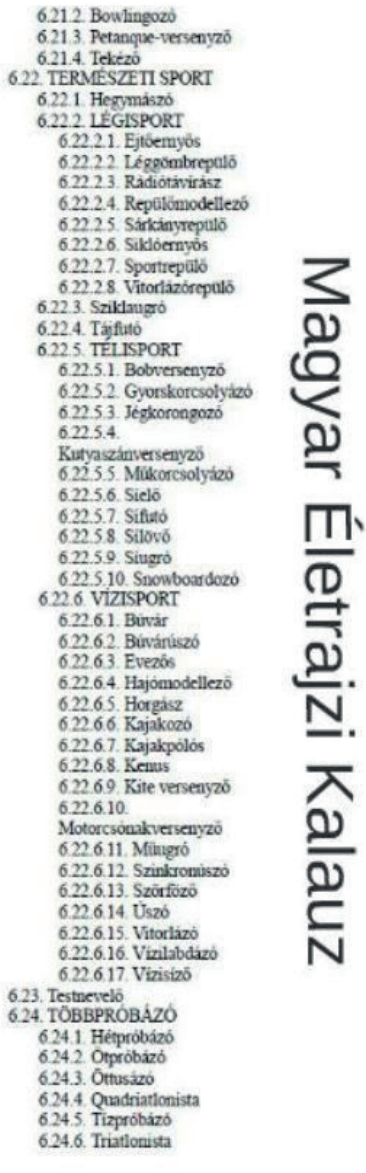

4. kép: A Magyar Életrajzi Kalauz és a World Biographical Index összehasonlitó foglalkozási listája (sport)

A nyomtatott források mellett egyre inkább fókuszálnunk kell az internet biográfiai erőforrásainak rendszerszemléletü feltárására is. E folyamatos pásztázás egyrészt a már említett MÉKADAT segédállomány épitését jelenti, másrészt a csak a világhálón hozzáférhető források feldolgozását (pl. Fejér Megyei Életrajzi Lexikon²), harmadrészt a kéziratos formában, kis példányszámban megjelent adattárak digitális forrásainak feltérképezését (pl. Evangélikus lelkészek Dunántúlon, 179319203), negyedrészt pedig a már feldolgozott források új, internetes elérhetőségének

2 http://konyvtar.vmk.hu/fejerlex/fejerlexikon.htm (Hozzáférés: 2019. március 14.)

3 https://medit.lutheran.hu/site/konyv/1567 (Hozzáférés: 2019. március 14.) 
Németh Tibor: Magánvállalkozás és közszolgálat: A biográfiai index múfaji megújitása a Magyar Életrajzi Kalauzban

feltüntetését. A világhálós források rendkivül illékonyak, ezért türelmet és óvatosságot igényel a kanalizálásuk, de fontosságuk egyre nő, ezért nem kerülhető meg, hogy a névkataszter aktualizálása, karbantartása érdekében e forrástípus is feltárásra kerüljön.

Hogyan foglalható össze a Magyar Életrajzi Kalauz müfaji újításainak filozófiája? A lényeg: magas fokú adatintegráció a használóközpontúság érdekében.

\section{Felhasználási területek}

34 év, több mint 12000 nap kitartó épitkezésének eredményeként jutottam el a mai szintre. Kilencedik négyéves olimpiai ciklusom felénél járok és továbbra is hiszek egykori álmom megvalósitásának lehetőségében. 1982 óta dolgozom a celldömölki városi könyvtárban és 1985-töl kezdve a mindenkori béremre vetítve kiszámoltam, hogy az adattárra fordított munkám az inflációs indexet is figyelembe véve reálértéken 2018. december 31-ig 94 millió 545 ezer 647 Ft-ot tett ki. Ebben benne van a kezdő 1500 Ft-os havi fizetésem és számításba veszi, hogy 32 év után 2018. április 1-töl heti egy kutatónapot vehetek igénybe...

A Magyar Életrajzi Kalauz komplex jellegéböl adódóan sokféle célra használható, amelyek közül izelitőként néhányat megemlitek. Az utolsó átfogó magyar ki kicsoda, az MTI Ki kicsoda 2009 megjelenése elött megkerestem az MTI-t, mert az elöző kiadásokban azt tapasztaltam, hogy sok már évekkel, söt évtizedekkel korábban elhunyt személyt tartalmaz az adattár. Felajánlottam a segítségemet ezek kiszürésében illetve a legfontosabb születési adatok pontositásában. A kért összességében több ezer adatnyi információt az együttműködési szerződésben rögzitettek szerint rendelkezésre bocsátottam, de a hivatalos dokumentumban rögzitettek ellenére nem tüntették fel nevemet a szerkesztöi névjegyzékben... $A$ példát csak azért emlitem, mert a feldolgozás során látom, hogy milyen sok forrás esetében jelentene minőségjavulást, ha megjelenés előtt ellenőriznék adataikat egy kontroll adattárban, ami lehet a Magyar Életrajzi Kalauz vagy a Petöfi Irodalmi Múzeum grandiózus adatbáziscsaládjának egyik ékköve, a Magyar Életrajzi Index4.

Egy ideig személyesen is részt vettem a Libinfo tájékoztató szolgálat müködésében, majd az adatbázis ingyenes rendelkezésre bocsátásával segitettem közérdekü tevékenységüket.

Büszke vagyok, de egyúttal fáj is a szivem, ha a "Nemzeti Évfordulóink" címü sorozatra gondolok. 11 esztendön keresztül, a 2008-as kötettöl a 2018-asig állitottam össze a következö év kerek, azaz 25-tel osztható évfordulós személyiségeinek alap szócikk-listáját, amelyre építve a szerkesztőség elkészitette az évkönyvet. ${ }^{5}$ Minden esztendőben az egyre bővülö adattáram szisztematikus átszürésével nyaranta hónapokat foglalkoztam ezzel az elökészitéssel. A Balassi Intézet átalakulása a 2019-es esztendő kimaradt, de 2020-tól a Petőfi Irodalmi Múzeum égisze alatt némileg megváltozott koncepcióval folytatódni fog a szinvonalas kalendáriumok sora.

$4 \quad$ Ld. Murányi Péter: Két biográfiai index ad.atbázis formájában. A Magyar Életrajzi Kalauz és a Magyar Életrajzi Index. Könyvtári Levelezö/Lap, 13. 7-8. Sz. (2001), 23-30. (http://epa.oszk.hu/00300/00365/00001/pdf/KLL_EPA00365_2001-07-08_023-030.pdf) (Hozzáférés: 2019. március 14.)

5 http://www.balassiintezet.hu/hu/kiadvanyok/nemzeti-evforduloink/ (Hozzáférés: 2019. március 14.) 
Ha a "Nemzeti Évfordulóink" szivszerelem, akkor mit mondhatnék az általam szerkesztett és jórészt irt Kemenesaljai Életrajzi Lexikonról? A városi könyvtárunk mühelyében régóta készült szócikkek eleinte a világhálóra kerültek fel és mindig vártam a pályázati lehetőséget, hogy nyomtatott formában is napvilágot láthasson. A Leader program keretében 2014 végén 2000 példányban úgy jelenhetett meg az elegáns kivitelü kötet ${ }^{6}$, hogy az érdeklődők ingyen juthattak hozzá. Az már csak hab volt a tortán, hogy kiadója a szülöfalum Kemenesaljai Regionális Ifjúsági Szervezete volt. Csöngei impresszummal nem hiszem, hogy túl sok kötet jelent meg valaha....

Az adattár karbantartása mellett állandóan keresem a folytatás és az együttmüködések lehetőségeit. A legtermészetesebb módon a "Nemzeti Névtér"rel7 alakult ki a kapcsolat. Megtiszteltetés számomra, hogy közremüködhetek ebben a vállalkozásban és bízom abban, hogy hosszú távon, eröforrásainkat koncentrálva dolgozhatunk együtt közös céljaink megvalósításáért.

A együttmüködési lehetöségek következő területei még képlékenyek, de jóleső kihivásként tekintek rájuk. A Magyar Életrajzi Kalauz jellegéböl adódóan a magyarságkutatás, az identitás feltárásának fontos terepe lehet. A lokális információk böséges tárházaként természetes módon lehet együttmüködö partnere a honismereti-helytörténeti mozgalomnak.

Ha nyitottak vagyunk a jövöre, akkor nem kerülhető meg a közösségi média csatornáinak felhasználása. Biztos vagyok abban, hogy az adatbank kontrollált társadalmasításával a közösségi platformok eröforrásai felszabadithatók a minőségi együttmüködés érdekében.

\section{Személyes záró gondolatok}

Szilárd meggyőzödésem, hogy személyes áldozatvállalás nélkül nem valósulhat meg egyetlen nemzeti jelentőségü ügy sem. A feladat nagyságának jellemzéséhez talán elég arra utalnom, hogy jelen pillanatban annyi elvégzendő retrospektív munkát látok magam elött, ami a következő 35 évre elég lenne a friss források feldolgozása nélkül is...

2014 szeptemberében részt vettem a halálának centenáriuma alkalmából megrendezett Szinnyei József-emlékkonferencián. A rendezvény előtt kilátogattam Szinnyei sírjához a Kerepesi temetöbe és az üres sírra elhelyeztem emlékező sírcsokromat. A zuhogó esöben lépten-nyomon csigákra kellett ügyelnem illetve mókusok cikáztak a sírok között. Projektorientált világunkban furcsa mókus vagyok magam is, hiszen 34 éve munkaidőn kivül, ingyenes munkával mintegy digitális gőzhangyaként dolgozom az általam felvállalt nemes ügy érdekében, bár jómagam csigalassúságúnak tekintem az elörehaladást... Reményeim szerint a modern technológia eszköztárával sikerrel próbálom ötvözni a nagy tömegü adatkezelést a Szinnyei-Gulyás-Viczián triász" által fémjelzett "kézműves alapossággal"...

\footnotetext{
$6 \quad$ Kemenesaljai életrajzi lexikon. Csönge, 2014. 222 p.

7 Ungváry Rudolf: A névtér, mint kulturális szükséglet. A nemzeti aggregátor kitüntetett feladata. Tudományos és Müszaki Tájékoztatás, 59. 8. sz. (2012), 320-326. (http://tmt.omikk.bme.hu/tmt/article/view/718/10593) (Hozzáférés: 2019. március 14.)

8 Czigány Lóránt: Szinnyei-Gulyás-Viczián. Magyar Könyvszemle. 113. 1. sz. (1997), 104-108.
} 
Németh Tibor: Magánvállalkozás és közszolgálat: A biográfiai index müfaji megújitása a Magyar Életrajzi Kalauzban

Saját sorsom és a "Magyar Életrajzi Kalauz" összefonódó históriáján keresztül élem meg azt, hogy "a Big Data már nem csupán a professzionális felhasználók kiváltsága, a tárhely és a számitási teljesitmény növekedésével és ezek árának csökkenésével a mindennapi felhasználók is részeseivé válhatnak a Big Data paradigmájának"9.

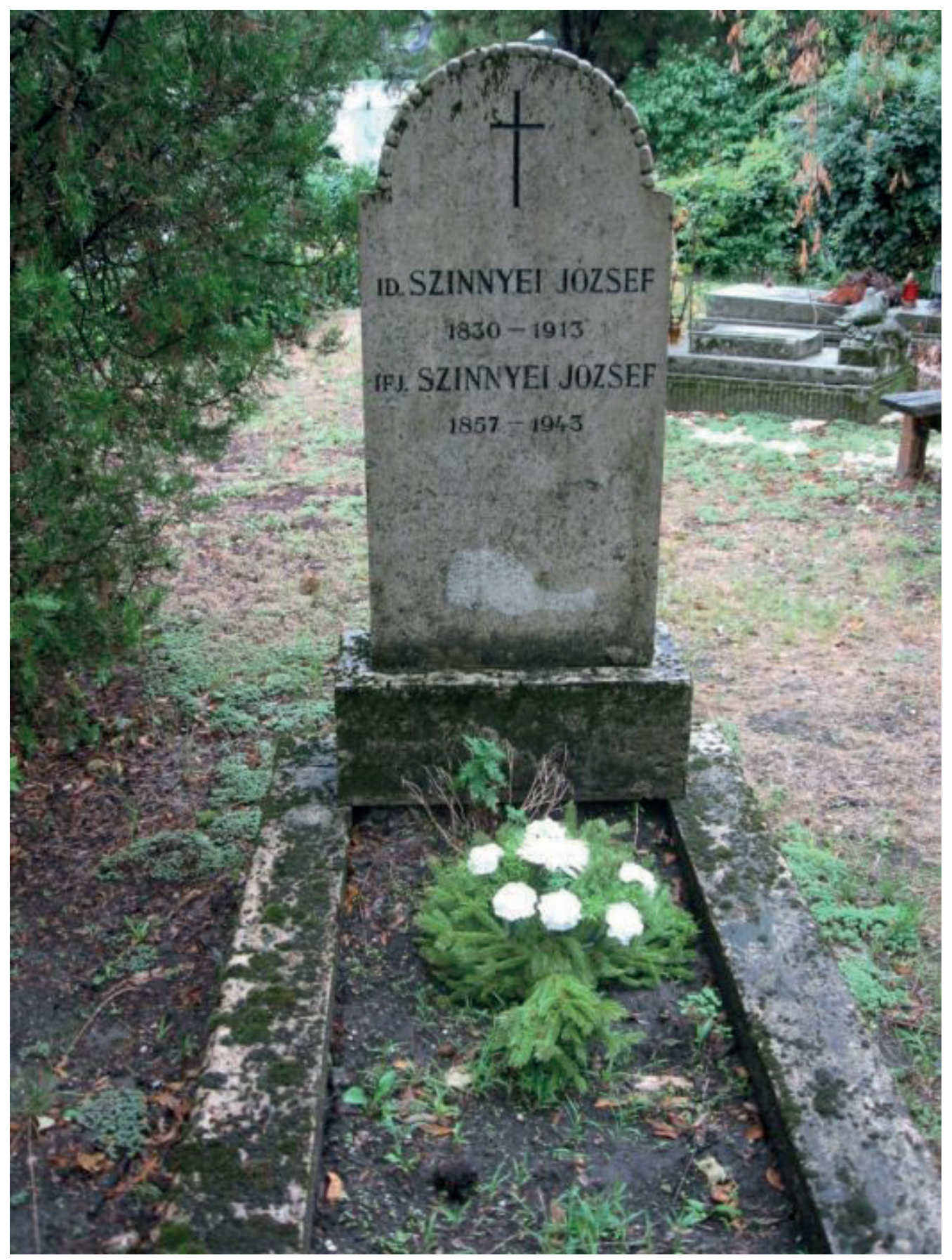

9 Szüts Zoltán-Jinil Yoo: Big Data, az információs társadalom új paradigmája. Információs Társadalom. 16. 1. sz. (2016), 12. (https://informaciostarsadalom.infonia.hu/index.php/inftars/ article/view/6/it_2016_1_1_szuts_yoo) (Hozzáférés: 2019. március 14.) 


\title{
Az elektronikus szakirodalmi információforrások hazai lelöhelyadatbázisa, a COMPASS
}

\author{
Sütő Péter \\ MTA Könyvtár és Információs Központ EISZ Titkárság \\ (grid.496758.1)
}

\section{COMPASS, the database of scientific e-resources available in Hungary}

Hungarian university- and research libraries purchase most of their electronic scientific content in the framework of consortium-level agreements via Electronic Information Service National Programme (EISZ). Apart from acquisitions, it is also the goal of EISZ to ensure the utilisation of the available content for the wide community. For this reason, the development of COMPASS database was started in autumn 2016 in order to collect, organise, and make available the scientific databases and electronic documents purchased by the consortium or the institutions individually.

In September 2017, a newly developed version of COMPASS was launched on a new platform. The database provides multiple options for searching and interacting with scientific contents available in Hungary. In addition, it offers direct access to the databases for eligible users, as well as links to the full text of Open Access articles.

The paper covers how much the goals and plans of the project have been achieved, and describes the new functionalities and the experiences of the operation and usage since the database was launched.

Keywords: union catalogue, e-resources, electronic document delivery, open access

\section{Bevezetés}

Napjainkban a tudományos szakirodalom egyre nagyobb mértékben elektronikus formában jelenik meg, amely magával hozza a tudományos közösség igényét is az elektronikus formátumban rejlő előnyök iránt. Ez a folyamat Magyarországon is jól érzékelhető, a hazai felsőoktatási- és kutatóintézetek is nagyobb részt elektronikus formában szerzik be a szakirodalmat és teszik elérhetővé a felhasználóik számára. ${ }^{1}$

A hazai kutatóközösség szakirodalommal való ellátását az Elektronikus Információszolgáltatás Nemzeti Program segíti elő azzal, hogy lebonyolítja az elektronikus tudományos információforrások beszerzését konzorciumi keretek között a hazai felsőoktatási és non-profit kutatóintézetek számára. 2019-ben az EISZ programon keresztül több mint 230 intézmény szerzi be az elektronikus információforrásait, közel 180 adatbázist, e-folyóirat- és e-könyvcsomagot, ami azt jelenti, hogy többszázezer tudományos publikáció érhető el elektronikusan Magyarországon konzorciumi elöfizetések keretében.

\footnotetext{
$1 \quad$ Dér Ádám, Lencsés Ákos. Az EISZ Nemzeti Program szerepe a könyvtárak külföldi szakirodalommal való ellátásában. Tudományos és Müszaki Tájékoztatás 64, 5. sz. (2017): $241-246$
} 
Óriási lehetőségeket rejt magában ennek a hatalmas mennyiségü publikációnak a rendelkezésre állása, azonban felmerülnek a következö kérdések:

- Hogyan képesek ezt az információhalmazt a kutatók és a könyvtárosok áttekinteni és hatékonyan felhasználni?

- Hogyan tud ez az egyes intézményeken keresztül rendelkezésre álló forrás az ország teljes tudományos közössége számára hasznosulni?

Ezeket a kérdéseket az EISZ Titkárság munkatársai már 2016-ban is feltették maguknak és válaszként megszületett a COMPASS² továbbfejlesztésének terve, azaz egy országos elektronikusforrás lelőhelyadatbázis létrehozása.

\section{A fejlesztés céljai ${ }^{3}$}

A fejlesztés kezdetén, 2017. elején kiemelt célként fogalmaztuk meg, hogy a lelőhelyadatbázis segitse elő a szakirodalmi információkhoz való legális hozzáférés lehetőségének kiszélesitését, a források elérésének meggyorsítását, a hazai intézmények konzorciumi elöfizetései mellett az egyéni elöfizetéseik láthatóságát, mint fontos felhasználói szempontokat.

Természetesen a gyarapitási, fenntartói és tudományszervezési szempontok is hangsúlyosan megjelentek a célok között, úgymint a költséghatékonyság elősegítése, az országos tudományos tartalombeszerzés áttekinthetősége, a fejlesztésre szoruló területek feltérképezése és az intézményi kapcsolatok erősítése. Ezekkel a szempontokkal a COMPASS tervezett célja volt, hogy támogatást nyújtson akár stratégiai tervezési szinten a döntéselőkészitő folyamatokhoz is.

\section{A fejlesztés eredménye}

A célok elérése érdekében a már létező COMPASS felülethez egy PhP alapú MySQL adatbáziskezelöt használó keresőmotort fejlesztettünk, amely a már meglévő szükös keresési lehetőségek4 (adatbázis, intézmény és település keresők) hatékonyságát jelentősen növelte és lehetővé tette a keresési lehetőségek kibövítését.

Figyelembe kellett ugyanis venni azt, hogy a felhasználók elsősorban az öket érdeklő folyóirat, vagy cikk adatainak vannak a birtokában, nem pedig annak, hogy az melyik adatbázisban érhető el. Tehát csak akkor müködhet hatékonyan a lelőhelyadatbázis, ha a cimszintü keresési lehetőség is rendelkezésre áll.

A tervezés során a következő szint, a cikkre való keresés biztositása is felmerült, melyet a lehetőségek vizsgálata után a Crossref OpenURL használatának segitségével sikerült megvalósítani. Ez azt eredményezte, hogy a COMPASS-on

\footnotetext{
2 A COMPASS elérhetősége http://compass.mtak.hu

3 Dér Ádám, Nyiscsák Sándor. A COMPASS adatbázis új verziójának fejlesztése. (Networkshop 2017. Szeged) 2017. április 20. URL: https://conference.niif.hu/event/7/session/5/contribution/52/material/slides/o.pdf

4 Páll Zoltán. COMPASS - Iránytü az információhoz (az MTA KIK EISZ új információszolgáltató adatbázisa). (Networkshop 2015, Eger) 2015. április 1. URL:

https://conference.niif.hu/event/3/session/14/contribution/80/material/slides/1.pdf
} 
keresztül lehetővé vált a keresés a DOI azonositóval rendelkező publikációk közel teljes halmazára.

A lelőhelyadatbázis hatékonyságának kiteljesedését pedig a cikkszintü kereséshez kapcsolódóan az open access cikkek közvetlen hozzáférésének biztosítása jelentette. Ez a funkció az Unpaywall (korábban oaDOI) API- $n^{5}$ keresztül éri el a cikkek open access státuszára vonatkozó metaadatokat, amelyek automatikus feldolgozásával úgy a green, mint a gold open access cikkek teljes szöveghez vezető linkjei is megjelennek a COMPASS találati listájában. ${ }^{\circ}$

\section{Tapasztalatok a használati adatok tükrében}

A COMPASS jelenlegi verzióját 2017. szeptemberében élesitettük, azaz 1,5 év használati adatai állnak rendelkezésre.

A COMPASS jelenlegi tartalmának adatbázistípusok szerinti megoszlását (1. ábra) áttekintve jól látszik, hogy milyen nagy arányban kerültek be az intézmények egyéni előfizetései is az adatbázisba. Ez egyrészt mutatja azt, hogy jelentős mértékben sikerült bevonni az intézményeket a COMPASS tartalmi bővítésébe, egyúttal megerősiti azt a kezdeti célkitüzést, hogy a COMPASS tartalma nőjön túl a konzorciumi portfólión és törekedjen teljes országos lefedettségre.

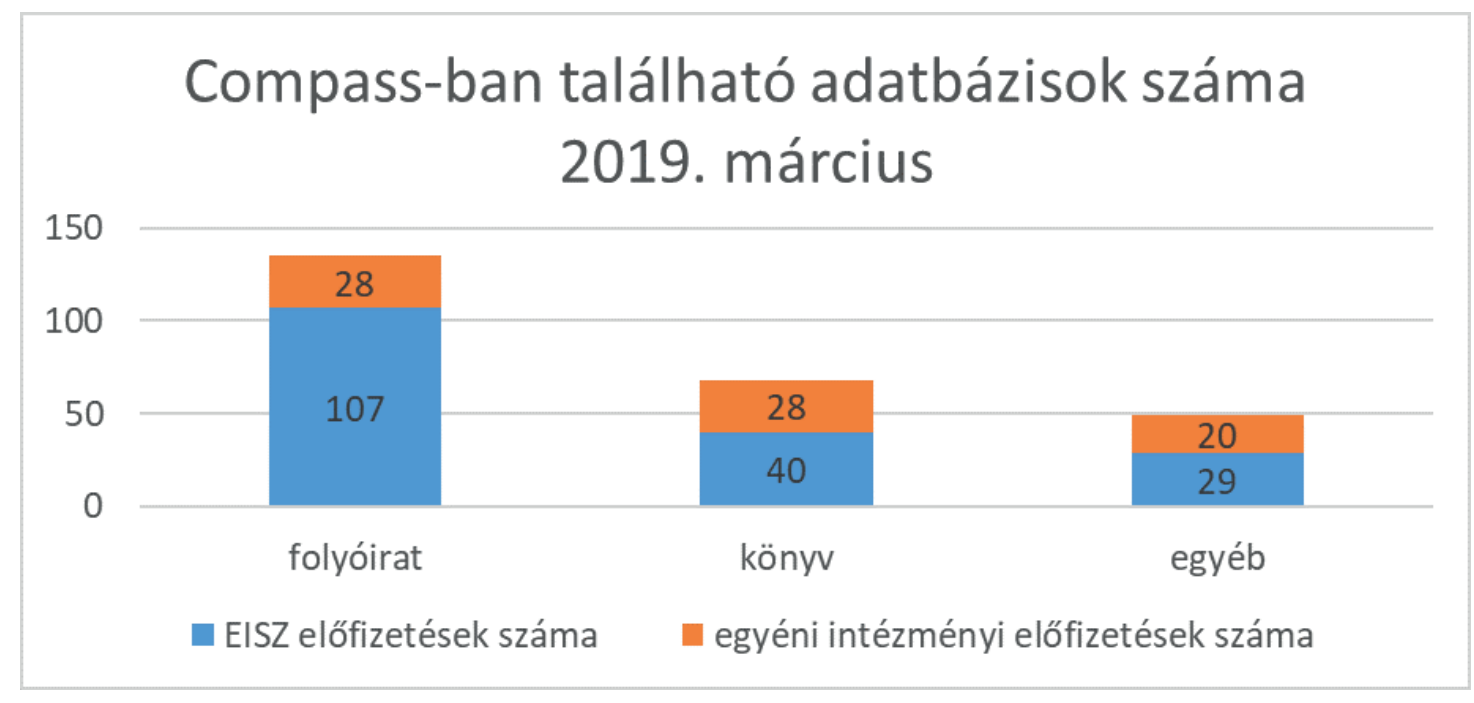

1. ábra: COMPASS-ban található adatbázisok száma, 2019. március

Mivel a COMPASS platform szabadon hozzáférhető mindenki számára ezért érdemes vizsgálni azt is, hogy honnan érkeznek a használatok (2. ábra). A célokkal összhangban azt tapasztaljuk, hogy a COMPASS-t az EISZ tagintézményeken kivüli IP tartományokból is nagy arányban használták, azaz lényegesen szélesebb használói kört ér el a lelöhelyadatbázis, mint a konzorciumi tagintézmények kutatói.

\footnotetext{
5 Az Unpaywall API elérhetősége http://unpaywall.org/products/api

6 Dér Ádám, Nyiscsák Sándor. A COMPASS adatbázis új verziójának fejlesztése. (Networkshop 2017. Szeged) 2017. április 20. URL

https://conference.niif.hu/event/7/session/5/contribution/52/material/slides/0.pdf
} 
Az elektronikus szakirodalmi információforrások hazai lelőhelyadatbázisa, a COMPASS

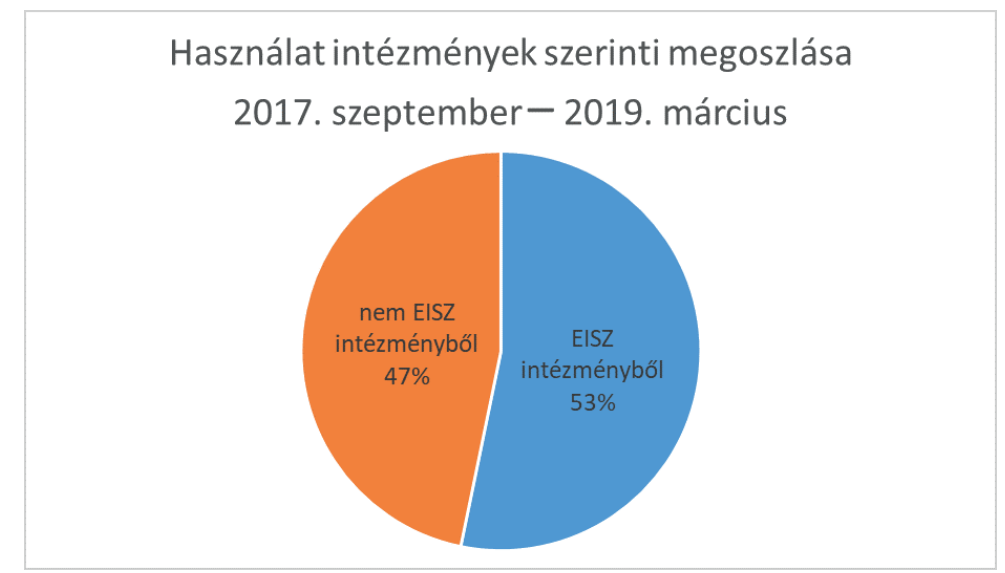

2. ábra: COMPASS használat intézmények szerinti megoszlása, 2017. szeptember - 2019. március

A COMPASS használata (3. ábra) az első 1,5 évalatt az elvárásoknak megfelelően alakult. Nem meglepö, hogy a folyóirat/könyv címre való keresés kimagaslik a többi keresési típus közül, hiszen a lelöhelyadatbázisnak ez az elsődleges funkciója. Egyúttal igazolja azt, hogy a fejlesztés egyik kulcs feladata volt a címszintü kereséssel való bövités.

Azonban az adatok azt mutatják, hogy a cikkszintü keresések (DOI keresések) száma alacsony. Kutatói és könyvtáros visszajelzések alapján ennek lehetséges oka az, hogy a DOI használata, mint keresökifejezés nem olyan kézenfekvő, mint egy folyóiratcím használata, még akkor sem, ha nem ugyanazon a szinten ad találatokat.

A DOI keresés alacsony használatából következik, hogy az Open Access cikk találatok száma is alacsony, és a részarányát tekintve is elmarad az Open Access cikkek globális arányától7. Ez rámutat arra, hogy mindenképpen növelni kell a felhasználók tudatosságát a cikkszintü keresésre.

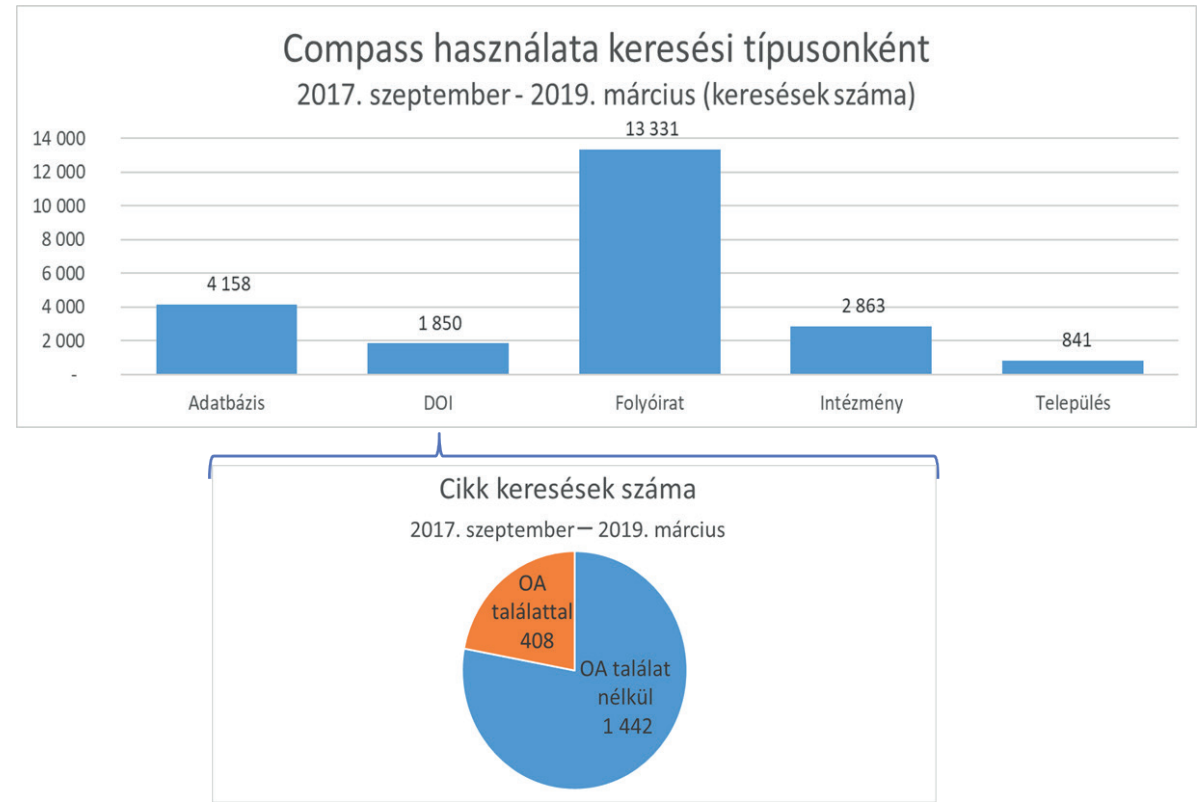

3. ábra: COMPASS használata keresési típusonként, 2017. szeptember - 2019. március

$7 \quad$ Piwowar H, Priem J, Larivière V, Alperin JP, Matthias L, Norlander B, Farley A, West J, Haustein S: The state of OA: a large-scale analysis of the prevalence and impact of Open Access articles. PeerJ. 6:e4375 (2018) https://doi.org/10.7717/peeri.4375 
Ha megvizsgáljuk a keresések hatékonyságát (1. táblázat), azaz a találatot adó keresések számát, akkor a keresési típusok között nagy eltéréseket tapasztalunk. A DOI keresésnek nagyon magas a találati aránya, ami a DOI keresőbe beépitett intelligenciának köszönhetö, mely felismeri a keresőmezőbe bevitt karaktersorozatban a DOI azonositót. Az adatbázis és folyóirat keresések alacsonyabb hatékonysága viszont arra enged következtetni, hogy vagy a felhasználók figyelmetlenek a keresés során, vagy a felhasználói igények szélesebbek, mint a COMPASS lefedettsége.

1. táblázat: Találati hatékonyság ${ }^{8}$ keresési típusonként, 2017. szeptember - 2019. március

\begin{tabular}{|l|r|}
\hline Dol keresés & $91 \%$ \\
\hline Intézmény keresés & $91 \%$ \\
\hline Település keresés & $75 \%$ \\
\hline Folyóirat/könyv keresés & $61 \%$ \\
\hline Adatbázis keresés & $50 \%$ \\
\hline
\end{tabular}

Ahhoz, hogy jobban megismerjük az alacsonyabb keresési hatékonyság okait, elemeztük a sikertelen keresések keresési kifejezéseit a leggyengébb mutatóval rendelkező adatbázisra történő keresésnél (2. táblázat).

A vizsgálat során azt láttuk, hogy a sikertelen keresések 29\%-a a hibás keresés közvetlen megismétléséböl adódik, azaz a felhasználó újra lefuttatja változatlan keresőkifejezéssel ugyanazt a keresést, ami nem adott találatot, mert nem hiszi el, hogy nincs találat. Ezeket a duplumokat a hatékonyság vizsgálata szempontjából figyelmen kivül hagyhatjuk.

Az elírásból adódó sikertelen keresések alacsony aránya (2\%) feltételezhetően a kereső mezöbe beépitett automatikus kiegészitő (autocomplete) funkciónak köszönhetö, ami mindenképpen igazolja ennek a fejlesztési elemnek a létjogosultságát.

Gyakori hiba (10\%), hogy az adatbázisra keresö fülön folyóiratra, esetleg intézményre keresnek a felhasználók, illetve hasonló félreértés a kiadókra való keresés (4\%). Ez részben figyelmetlenségböl adódik, azaz a felhasználó elfelejt átkattintani a megfelelö fülre, másrészt félreértésböl, miszerint a kiválasztott fül nem az elérni kivánt eredményt, hanem a beírandó keresőkifejezést specifikálja. Ezeken a mutatókon a keresőfelület felhasználókat segitő információinak pontosabb megjelenítésével, valamint a keresési algoritmus kiadóra és alternatív névre való kiszélesítésével várhatóan tudunk javítani.

8 (az adott kereséstípus esetén találatot adó keresések száma) / (adott kereséstipus esetén lefuttatott összes keresés száma) 
A legnagyobb halmazt a hibás keresésék között a tárgyszóra történő keresés (34\%) teszi ki. Ez azt mutatja, hogy a felhasználók egy része nem lelöhelyadatbázisként, hanem egy általános tudományos információforrásként próbálja használni a COMPASS-t. Ezt a félreértést mindenképpen el kell oszlatni. A lelöhelyadatbázis célja nem az hogy szakirodalmat keressen általa a felhasználó a kutatásához, hanem az, hogy a már különböző forrásokban megtalált szakirodalmaknak megtalálja a magyarországi elérhetöségét, illetve amennyiben van nyilt hozzáférésü elérhetösége, akkor biztositson közvetlen elérést a cikk teljes szövegéhez.

A COMPASS-ból hiányzó keresett adatbázisok egy része nem releváns adatbázisra történt keresés volt - például Matarka, ODR -, más részük pedig tényleg hiányzott az adott időben az EISZ portfóliójából. Azonban sok közülük azóta már bekerült az elérhető adatbázisok körébe.

2. táblázat: Sikertelen adatbázisra történő keresések megoszlása a kereső kifejezések elemzése alapján9 ${ }^{9}$ 2017. szeptember - 2019. március

\begin{tabular}{|l|r|}
\hline újrafuttatott keresés & $29 \%$ \\
\hline nem értelmezhetö kifejezés & $0 \%$ \\
\hline elírás & $2 \%$ \\
\hline kiadóra keresés & $4 \%$ \\
\hline alternatív név & $4 \%$ \\
\hline más keresőmezőnek megfelelö kifejezés & $10 \%$ \\
\hline hiányzik az adatbázis a COMPASS-ból & $17 \%$ \\
\hline tárgyszó & $34 \%$ \\
\hline
\end{tabular}

\section{Felhasználói tapasztalatok}

A felhasználói tapasztalatok megismerése érdekében a partnerintézmények több mint 40 elektronikusforrás-menedzser könyvtárosával konzultáltunk és kaptunk visszajelzést közvetlenül a COMPASS egy elsődleges használói csoportjától.

Ennek során kiderült, hogy a könyvtári munka mely területein használják a COMPASS-t. A leghangsúlyosabb terület egyöntetüen a könyvtárközi kölcsönzés volt, míg meglepő módon az olvasószolgálat és a gyarapitás kevésbé jelentős felhasználási területek. Ez alapján úgy tünik, hogy a COMPASS elérte az intézményeket, de elsősorban az elektronikusforrás-menedzserek és a könyvtárközi kölcsönző kollégák ismerik, úgyhogy további időt és energiát kell ráforditani, hogy a Compass egy alapvető eszköz legyen minden hazai könyvtáros eszköztárában.

A felhasználói élményhez kapcsolódó visszajelzések alapján a kollégák a platformot könnyen kezelhetönek tartják, továbbá a keresési lehetöségeket és a keresés hatékonyságát is nagyon jónak gondolják. Ez utóbbi ellentmond a korábban látott hatékonysági adatoknak, azonban feltételezhetö, hogy a sikertelen keresések nem a gyakorlott könyvtárosokhoz köthetök.

9 (az adott keresési hibával lefuttatott adatbázisra keresések száma) / (összes sikertelen adatbázisra keresés száma) 
Abban teljes volt az könyvtárosok egyetértése, hogy a COMPASS-nak ismertebbnek kellene lennie a könyvtáros és a kutatói közösségben egyaránt, amit az EISZ is fontos feladatának tart a jövöre nézve is.

\section{Összegzés}

A Magyarországon elérhető elektronikus tudományos információforrások mennyisége átlépte azt a kritikus tömeget, hogy a köztük lévö eligazodáshoz és a hatékony országos szintü hasznosulásukhoz szükségessé vált egy lelőhelyadatbázis létrehozása.

Az elektronikus források konzorciumi beszerzését lebonyolitó EISZ Titkárság által 2017-ben továbbfejlesztett nyilt hozzáférésű COMPASS platform lehetővé teszi a források lelőhelyének visszakeresését adatbázis, folyóirat/könyvcím, vagy cikk szinten egyaránt, továbbá nyilt hozzáférésü cikktalálatok esetén a teljes szöveghez is közvetlen hozzáférést biztosit.

Az adatbázis használati adatainak elemzése rámutat arra, hogy a keresöplatform sokkal szélesebb használói kört ér el, mint az adatbázisokra előfizető intézmények kutatói és igazolta a fejlesztés egyik kulcselemének, a címszintü keresésnek a fontosságát. A keresések hatékonyságvizsgálata segitett feltárni a még fejlesztendő elemeket, melyeken jelenleg is dolgozunk.

A könyvtáros felhasználói tapasztalatok pozitívak a könnyü kezelhetőség, a funkcionalitás és a hatékonyság szempontjából egyaránt, viszont szükséges a COMPASS ismertségének növelése, hogy egy mindennapos referensz eszköz legyen a könyvtárosok kezében és egy használt eszköze legyen a kutatóknak.

\section{Bibliográfia}

Dér Ádám, Lencsés Ákos. Az EISZ Nemzeti Program szerepe a könyvtárak külföldi szakirodalommal való ellátásában. Tudományos és Müszaki Tájékoztatás 64,5 . sz. (2017): 241-246.

Dér Ádám, Nyiscsák Sándor. A COMPASS adatbázis új verziójának fejlesztése. (Networkshop 2017, Szeged) 2017. április 20. URL: https://conference.niif.hu/ event/7/session/5/contribution/52/material/slides/o.pdf

Páll Zoltán. COMPASS - Iránytü az információhoz (az MTA KIK EISZ új információszolgáltató adatbázisa). (Networkshop 2015, Eger) 2015. április 1. URL: https://conference.niif.hu/event/3/session/14/contribution/80/material/ slides/1.pdf

Piwowar H, Priem J, Larivière V, Alperin JP, Matthias L, Norlander B, Farley A, West J, Haustein S. The state of OA: a large-scale analysis of the prevalence and impact of Open Access articles. PeerJ. 6:e4375 (2018) https://doi.org/10.7717/peerj.4375 


\title{
E-Learning rendszer és elektronikus tananyagfejlesztés a Könyvtári Intézetben
}

\author{
Szepesi Judit \\ Országos Széchényi Könyvtár, Könyvtári Intézet \\ szepesi.judit@oszk.hu
}

We would like to present the plans of an e-learning system for the Hungarian Library Institute. Within the OKR project of the National Széchényi Library we develop also electronic training materials for librarians.

Keywords: e-learning, e-learning system, blended learning, Hungarian Library Institute, professional training.

\section{Bevezetö}

A teljes életpályára kiterjedő képzés igénye és az oktatási médiumok (nyomtatott, elektronikus) változatainak fejlödése révén egyre szélesebb körben alkalmazzák a hagyományos oktatási formák mellett az elektronikus eszközökkel támogatott blended képzéseket. E képzési forma rugalmas módon támogatja a munka melletti tanulást, figyelembe véve a képzésben résztvevők eltérö felkészültségét, tanulási szokásait és időbeosztását.

Az Országos Széchényi Könyvtár, az Országos Könyvtári Rendszer projektjének részeként a Könyvtári Intézet távoktatási rendszerének

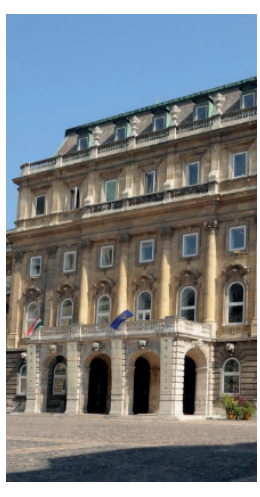
a megújitásán és multimédiás tananyagok fejlesztésén dolgozik.

A 2018-as Networkshop-on beszéltünk elöször a fejlesztési tervekröl, jelen összefoglaló célja, hogy az azóta történt munkát bemutassa.

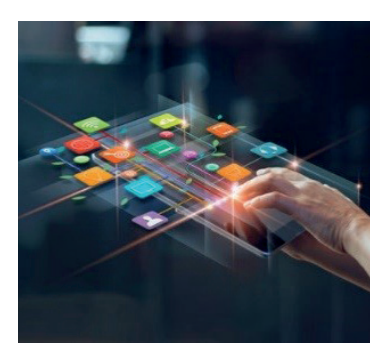

\section{E-learning rendszer}

Jelenleg az e-learning rendszerünk közbeszerzési folyamata még nem zárult le, ezért a terveket csak röviden - a lényeges elemeket kiemelve - mutatom be.

Tervezési munkánk során meg kellett állapítanunk, hogy az e-learninghez kapcsolódó szóhasználat és a meghatározások ellentmondásokat, illetve néhol átfedéseket mutatnak. Ez föleg abból adódik, hogy magát az e-learning rendszert sokszor azonositják azzal a szoftverrel, alkalmazással, keretrendszerrel, amely támogatja az online oktatást, a tanulást és az oktatásszervezési feladatokat. Véleményünk szerint a tanulási folyamatokat támogató keretrendszer csak egy eleme lehet az e-learning környezetnek, és mellette más online és/vagy offline alkalmazások is szükségesek.

A projekt keretén belüli tervezés során a tanulási környezet kialakitása mellett további modulokat is tervezünk, amelyek megkönnyitik az oktatásszervezök számára az egységes adatkezelést, átláthatóvá teszik a dokumentációkat. 
A tervezés során fontosnak tartottuk a szabványok használatát, ezzel biztosítva a rendszer átjárhatóságát.

\section{Célkitüzésünk}

A fejlesztési feladat célja olyan weben elérhető e-learning portál (szolgáltató rendszer) kialakitása, amely támogatja a Könyvtári Intézet továbbképzési tevékenységéből fakadó adminisztrációs és dokumentációs feladatok ellátását. Újdonság lesz, hogy a tervek szerint az Országos Széchényi Könyvtár belső képzéseit is támogatni fogja a portál. A rendszer használatával lehetőséget szeretnénk adni más könyvtáraknak is, hogy - megfelelő felkészítés után - saját szakmai oktatási tevékenységüket ezen keresztül szervezhessék.

Az oktatási tartalmak egy böngészőn keresztül lesznek hozzáférhetök. A tanulási folyamatokhoz web 2.0-ás környezetet hozunk létre. amely alkalmazásaival közvetlenül és közvetetten is támogatja a kapcsolatok kiépitését és a közösségi tanulás folyamatát. A tanulási környezetben mini blogolási lehetőséget kinálunk, google alkalmazásokat építünk be (Pl. Google calendar eseményértesítővel).

Az elkészült tananyagokat egy tananyagtárban helyezzük el, ahol gondoskodunk a tananyag-elemek és a tananyagok feldolgozásáról, tárolásáról. Elképzelhetőnek tartjuk egy nyilt forráskódú dokumentumkezelő vagy tartalomkezelö rendszer beépitését a rendszerbe (pl.: Liferay, Dispace).

\section{A tervezett rendszer elemei}

- webes szolgáltató felület

Az e-learning portál egy szolgáltató felület, amely mögött moduláris felépitésü programrendszer támogatja az oktatásszervezési, tanulási, tanulás-irányítási, oktatási feladatok elvégzését, valamint a digitális tananyagtár kezelését.

- oktatásszervezési modul

Háttéradatbázisok és ürlapok segitségével teljes körüen képes ellátni a képzések (OKJ-s képzés, akkreditált tanfolyamok, nem akkreditált belső képzések) szervezéséhez szükséges adminisztrációs és dokumentációs feladatokat.

- tanulási és oktatási folyamatokat támogató modul

A tanulásirányítási oldal olyan eszközöket nyújt, amelyek segitségével könnyen megtervezhetö és összeállitható egy továbbképzés tartalma, a tanfolyamok lebonyolithatók, a tanulási folyamatok nyomon követhetők, ellenörizhetök. Törekszünk arra, hogy a tananyagok mobil eszközökön is elérhetök legyenek.

- digitális tananyagtár

A tananyagtár olyan - az aktuális képzéseket támogató - gyüjtemény, amely biztositja az interaktiv, multimédiás tananyagok, tanulási elemek és objektumok szabványos módon történő feltöltését, feldolgozását (Dublin Core és/vagy LOM alapú leíró adatok hozzárendelését), kereshetőségét és használatát. 


\section{Multimédiás tananyag}

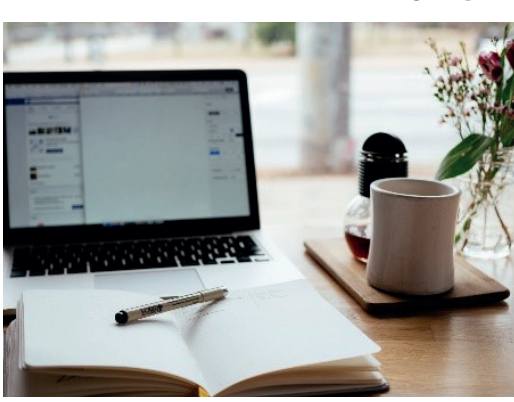

A közbeszerzés során a multimédiás tananyagok kialakitására többen is pályáztak, a nyertes pályázó az OnlearnTech Kft. lett. A fejlesztés során négy tananyag születik meg, amelyek a késöbbiekben blended képzésekbe épülnek be. (témakörök: webarchiválás, állományvédelem, digitalizálás, az e-learning módszertana, szerzői jogi tudnivalók az elektronikus tananyag használatáról)

Mielőtt azonban a fejlesztés lépéseit röviden bemutatnám, szeretném fogalommeghatározással kezdeni. Ezen a területen is különbözö megvalósitási formákba, típusokba botlottunk, ezért a magunk számára így értelmeztük az elektronikus tananyag fogalmát:

Olyan pedagógiai elvek alapján, az informatika eszközeivel felépitett oktatási tartalom, amely önálló, módszertani szempontból zárt egységet alkot, de akár egy vagy több képzéshez is illeszkedhet. Felépítését és alkotóelemeit szabvány rendszerezi. Alapvető célja egy adott kompetencia kialakitása, fejlesztése.

A fejlesztés során az a célunk, hogy weben elérhetö, a könyvtári szakmai továbbképzést támogató, szabványos, multimédiás, interaktiv tananyagok készüljenek, amelyek internetes böngészőkben, mobil eszközökön és egy nyilt szabványokat és open source megoldásokat támogató rendszerben is lejátszhatók, megtekinthetök.

\section{Általános formai elvárásaink a multimédiás tananyaggal szemben}

Egységes, a tartalomhoz illö design, amely felhasználóbarát és könnyen kezelhetö Egységes megjelenés, témakörök szerinti színválasztás. Felhasználóbarát, menürendszere átlátható és könnyen kezelhető, a navigálás egyszerü. A szép design a felhasználó számára eszköz, amely segiti a tartalom megtalálásában (pl. egyértelmü ikonok segitségével).

Szabványos megoldásokat alkalmaz (pl.: HTML5, SCORM)

Egy jól müködő elektronikus tananyag alapja az e-learning szabványok használata, ezek biztositják a tananyagok megtekinthetöségét, lejátszhatóságát és kereshetöségét a különböző típusú, tanulási folyamatokat menedzselő rendszerekben. Az ily módon elkészitett tananyagok elemei, objektumai újrahasznosithatók egy új képzés kialakitása során. A legismertebb e-learning szabvány a SCORM, amelynek több verziója is napvilágot látott már.

\section{Interaktiv elemeket tartalmaz}

Az interaktiv elemek kiegészitik a szöveges tananyagot, segitik és támogatják a tanulás hatékony megvalósulását. Egyszerü, játékos, interaktív megoldás lehet pl. drag and drop tesztek használata. A teljesitmények elismerésének az egyik formája lehet pl. kitüzők (badges) adása. 
Reszponziv megjelenitést biztosit

A felhasználói élmény biztositása, a tananyagok jó olvashatósága, hordozhatósága, lejátszhatósága okos eszközökön (pl:: okostelefon, tablet) elengedhetetlen. A reszponziv megjelenítés jellemzöje, hogy eszközfüggetlenül, rugalmasan alkalmazkodik a böngészők felületéhez azért, hogy optimális megjelenést adjon. Szabványa a HTML5-t kiegészítő CSS3.

\section{A tananyagok felépítése}

A tananyagok felépitése moduláris. Az egy modulba tartozó leckék jellemzője, hogy közöttük tartalmi-logikai kapcsolat van.

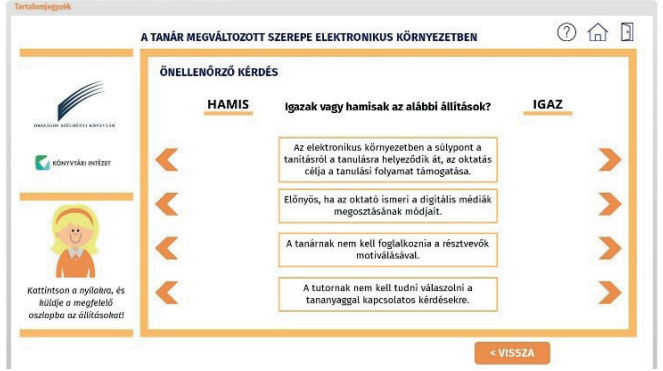

\section{A fejlesztés folyamata}

A multimédiás tananyag tervezésekor meghatározott célrendszer rögzitése után és arra épülve készittettük el a kéziratokat az adott téma szakértőivel.

A kéziratírás során jött létre az az oktatási tartalom, amellyel a továbbiakban a tananyagfejlesztök dolgoztak. Ez tekintjük a végleges tananyag háttéranyagának, szakmai dokumentációjának. (A teljes kéziratot az egyes moduloknál letölthetővé tettük.)

Ez az oktatási tartalom alakul tovább, ebben a formában még nem rendelkezik az online tananyagok jellemzőivel, lineáris és statikus. Ebben a fázisban már együtt dolgoztunk a szerzőkkel és a fejlesztökkel. Közösen emeltük ki a lényeges gondolatokat, az alapfogalmakat és minden olyan tanulási egységet, amely a tananyag sikeres előállításához és használatához tartozik.

Ebben a fázisban gondoskodtunk azoknak az elemeknek a megtervezéséről is, amelyek az oktatási tartalmat kiegészitik, illusztrálják (pl.: kép, videó, animáció, hanganyag, design elemek).

A következö lépésként elkészültek a forgatókönyvek, amelyek tükrözik a kézirat szerkezeti felépitését, de azon túlmutatnak a didaktikai elemek beépitésével. Elkészitésük során jött létre a végleges tartalom és a médiaelemek listája, egy adott szerzői rendszerre specializálódva. A digitális tananyag összeállitása a forgatókönyvben található szövegek, módszertani elemek és multimédia állományok jelölése alapján, azok pontos meghatározásával történt. 
Az elektronikus tananyag tervezési folyamatában a forgatókönyv elkészitéséhez prototípusokat alakitottunk ki a fejlesztőkkel, amelyek támogatják a szöveg egységes megjelenését, stílusát és az oktatási tartalom tagolását.

A fejlesztők az elkészült tananyagokat úgy adják át, hogy lehetőségünk legyen a későbbiek során a tartalmak átdolgozására, frissitésére.

A tananyag tesztelésébe a kéziratok szerzőit is bevontuk, velük együttmüködve, véleményük, javaslatuk alapján végezzük el a módositásokat, változtatásokat. A végső változatnak stilisztikai, müfaji és müködési szempontból kifogástalannak, hibátlannak kell lennie.

\section{Folyamatban lévő tananyagfejlesztések}

A Könyvtári Intézet módszertani vezetésével a szakmai továbbképzésekhez további témákat választottunk ki, amelyekröl szakértők bevonásával 20 db kézirat készült el.

Multimédiás tananyaggá alakitásukhoz jelenleg forrást keresünk.

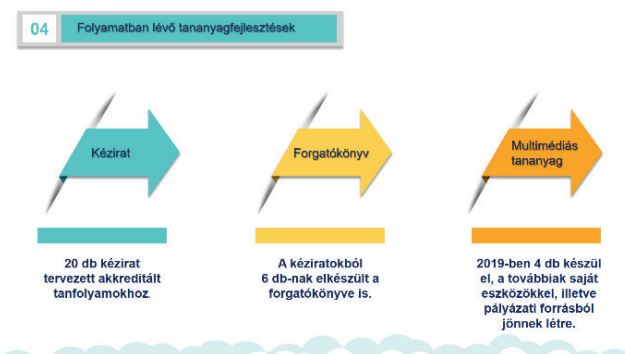

\section{Képzők képzése}

A Könyvtári Intézet oktatóit és a projektben fejlesztés alatt álló tananyagok szerzőit egy rövid képzés során készitettük fel a kéziratok megírására.

A képzés célja, hogy a résztvevök a tananyag elsajátítása során megismerjék az e-learning és az elektronikus tananyag fogalomrendszerét, felépitését, képesek legyenek arra, hogy - saját témakörükhöz - önállóan létrehozzák egy elektronikus tananyag kéziratát, valamint tanácsadóként részt vegyenek az e-learning oktatási tartalom kialakitásában.

A projektünk az OKR fejlesztéssel is kapcsolatban van, ezért a késöbbiek során az ott jelentkező oktatási igényeket is figyelembe vesszük, illetve a partner könyvtárakban dolgozó kollégákat is igyekszünk felkésziteni a rendszerünk használatára, valamint elektronikus tananyagok készitésére.

A képzések további célja a szemléletváltás támogatása, a szakmai kompetenciák fejlesztése és új ismeretek átadása.

\section{A multimédiás tananyagok helye és szerepe a továbbképzésben Online oktatás}

Munkánk során több alkalommal is belefutottunk abba, hogy az online tanulási és oktatási környezet meghatározása mennyire sokszinü. Az online oktatásmódszertan esetében mégtöbb változatot és lehetőséget tapasztaltunk, ezek közül pár fogalmat emelnék ki: távoktatás, e-learning, blended learning, online oktatás, 
konnektivizmus. A meghatározásokat tovább árnyalhatja az, hogy melyik szakmán belül használják.

Számunkra - meghatározása és felhasználási módja miatt -- a mai magyarországi tanulási és oktatási módszerek közül a blended learning látszik legmegfelelőbbnek. A "kevert képzés” olyan oktatásmódszertani megoldás, amely egymásba integrálja a kontakt tevékenységeket az online tevékenységekkel, az irányitott tanulást az önszabályozó tanulással, vagyis az online oktatást a jelenléti oktatás kiegészitéseként értelmeztük.

Ennek fényében a kontakt (gyakorlat) tevékenységek részben változatlan formában maradnak (tartalmi és módszertani szempontból), de az órák egy része helyettesithető online elérhető, multimédiás tananyagokkal, amelyek kiegészítik a jelenléti oktatást és többlet ismeretet adnak át. (információk, tudásanyagok, tesztek, feladatok stb.).

\section{Összefoglalás}

A Könyvtári Intézet - azon belül az Oktatási és Humánerőforrás-fejlesztési osztály -olyan oktatást támogató rendszer létrehozását tervezi, amely eszközöket biztosít az oktatásszervezéshez, támogatja az oktatási és tanulási tevékenységet és szabványos környezetet biztosít az elektronikus tananyagok szolgáltatásához, lejátszásához, tárolásához.

\section{Bibliográfia}

ANTAL Péter: Interaktív elektronikus tananyagok tervezése. Eger, Eszterházy Károly Föiskola, 2013. 175 p. (Médiainformatikai kiadványok)

Islam, Md. Shiful: How library and information science academic administrators perceive e-learning in LIS schools : a qualitative analysis. In: IFLA journal. - 40. (2014) 4., 254-266 p.

Kane, Kathryn: Tapping into social networking: collaborating enhances both knowledge management and e-learning. In: VINE. - 40. (2010) 1., 62-70p.

Komenczi Bertalan: Az E-learning lehetséges szerepe a magyarországi felnőttképzésben. Bp., Nemzeti Felnőttképzési Intézet, 2006. 60p.

Nagy Vitéz: „E-learning ABC”. In: Vezetéstudomány, 2016. XLVII. Évf. 12. szám, 6-15p.

Noesgaard, S. S. es Orngreen, R. es Foundation, K.: The Effectiveness of E-Learning : An Explorative and Integrative Review of the Definitions, Methodologies and Factors that Promote e-Learning Effectiveness. In: Electronic Journal of e-Learning, 13. volume, 2015. p. 278-290.

OKTATÁSTERVEZÉS, digitális tartalomfejlesztés. Szerk.: Ollé János, Kocsis Ágnes, Molnár Elöd. Eger : Líceum K., 2015. 266 p 


\title{
Besorolási, szabványosított, normatív vagy „autorizált”
}

\author{
Ungváry Rudolf \\ Országos Széchényi Könyvtár \\ ungvaryr@gmail.com
}

In English at the introducing of the MARC the former "heading" name had to be changed because in the description of the resource it denominated the data from the point of view of its place. In Hungarian this change was not necessary because the Hungarian name does not mean heading, it names the data based on its purpose. Disregarding the logic counter-arguments, at present the well accepted former phrase has been replaced - it was introduced the "authorized" ("autorizált") data phrase. The present study describes the pros and contras in the present debate, points out the misinterpretation of the phrase which has been successfully used until these days, and demonstrates why the suggested phrase is misleading and inaccurate.

Angol nyelven azért kellett a MARC megjelenésével megváltoztatni a korábbi besorolási adatot jelento "heading” nevet, mert az a besorolási adat elhelyezése szempontjából nevezte meg az adatot a forrás leírásában. A magyarban azért nem kellett ezt megtenni, mert a „besorolási adat” név nem a helye, hanem a rendeltetése szempontjából nevezi meg az adatot. Az ellenérveket semmibe véve most bevezették helyette az „autorizált” adat kifejezést. A tanulmány részletesen ismerteti az érveket, az ellenérveket, és rámutat a "besorolási adat” kifejezés félreértelmezésére, a javasolt kifejezés félrevezeto és hibás voltára. A „besorolási” jelző a maga tömörségével és szépségével nyelvi telitalálat volt.

\section{Egy terminológiai kérdés háttere}

Azért kellett angolul és németül a MARC előtti időkben kialakult "heading" és "Ansetzungsform" kifejezéseket megváltoztatni, mert ezek a helye szempontjából nevezték meg a tételt. Annak a helynek a szempontjából, amelyet a mindenkori dokumentumleírásban elfoglalt. A MARC-rekordban magát a "heading” és németül az „Ansetzungsform” kifejezést azonban továbbra is használták a rendszói részre és a közvetlenül hozzá kapcsolódó kiegészitő elemekre, és ez a magyarban továbbra is ugyanigy van. De maga az egész MARC-rekord nem csak a tételfejböl áll (lásd a 4. ábrát).

Ezzel szemben a „besorolási adat” kifejezés nem tételfejet jelent, holott a manuális gyakorlat idején valóban csak a tételfej képviselte ezt az adatot. Amikor tehát megjelent angolul az új „authority record” kifejezés, magyarul nem volt szükséges megváltoztatni a "besorolási adat” nevet. Már csak azért se, mert maga az MSZ 3440-es besorolási szabvány megszületésekor, 1979-ben (lásd a 3. ábrát) már létezett mint a Magyar Nemzeti Bibliográfia számítógéppel kezelt állománya. Ennek rekordjai lényegében a MARC-nak feleltek meg, még ha annak a magyar könyvtári szabványokhoz alkalmazott bibliográfiai MAMARC volt is. A HUNMARC, és annak besorolási formátuma 1988-ban jelent meg [5, 6, 7]. Hosszú ideig a "besorolási adat”, 
„besorolási rekord” kifejezés semmiféle értelmezési problémát nem okozott. 1998ban, tehát amikor a MARC már régen létezett, és a magyar HUNMARC besorolási adatcsere-formátum is készen volt, a „besorolási” jelző magyar használatát a MARC-rekordra senki se kifogásolta, holott angolul már évtizedek óta létezett az "authority" név. ${ }^{1}$

\section{Besorolási adat helyett „autorizált". Érvek}

Körülbelül két-három év óta Magyarországon az „autorizált formátum”, „autorizált adat” és az „autorizálás” kifejezés használatára akarnak áttérni.

Pártolói azt állítják, hogy a „besorolási adat”, „besorolási rekord” elavult, mert

(1) ma már nincs szó besorolásról;

(2) csak a könyvtári besorolási szereppel rendelkező adatokat tartalmazza, nem tartalmazza a tartalmi feltárással kapcsolatos újabb metaadatokat és relációkat, az adatkezeléssel kapcsolatos metaadatokat

(2.1) a MARC21 "authority” rekord sokkal több adatelemet tartalmaz, mint amennyit a korai ISBD és MSZ szabványokban rögzitettek;

(2.2) a MARC21 „authority” nemcsak több, de komplexebb, sokféleséget kifejező adatok értendők, és az „autorizáláson” komplexebb tevékenység értendő, mint a besorolási adatok szabványositott formáinak kialakitása;

(2.3) mivel a digitális információs térben sokféle forrásból kell összeterelni és összehangolni a metaadatokat, ezért összetettebb kognitív folyamatok zajlanak le:

(2.4) nem alkalmasak arra, hogy tágabb kontextusban is helyt álljanak. Nem beszélve olyan gyökeres ellentmondásokról, hogy az egységesitett besorolási adatok nem egységesek [8],

(2.4) „nem egyszerüsithetjük le a kérdéskört az egységesités és a besorolás nézöpontjaira [...] a reprezentálás elemibb adatok szintjén történik, a „besorolás” tényleg értelmezhetetlen ebben a közegben” [8];

(2.5) „Ma már egyenrangúak a névvariánsok, amelyek közül kiválasztható a kitüntetett névalak, a többi kezelése pedig az authority rekord feladata." [6]

(3) Az FRBR, FRAD, RAK a források kezelésének többszintü modelljén alapszik, ezen belül a megjelenési forma csak az egyik szint. [6]

$1 \quad$ A „besorolási adat” magyar kifejezés tehát 1998-ban is elfogadott volt, nem Vajda Erik találta ki egyedül, csak abban az évben regisztrálta egy elemzésében a név magyar használatának tényét a „besorolási rekord” esetére is. A HUNMARC esetében ugyanis azt már eleve használták azok, akik a változatait kidolgozták (és ezek a szakemberek, mint Sipos Márta, Szücs Jenöné nem azok közé tartoztak, akik az MSZ 3440 magyar szabványt 1976-ban létrehozták, hanem azok közé, akik a tényleges könyvtárinformatikai gyakorlatban ezt a rekordtipust tevőlegesen a Magyar Nemzeti Bibliográfához előállitották. Nekik semmiféle problémájuk nem volt a kifejezéssel - pedig ekkor már nem csak a tételfejet kellett meghatározni folyamatosan, hanem magát a rekordot is.

2 Az ellenérveket kifejtette Dudás Anikó [1, 2, 3] és a Katalisten Tóvári Judit [8] 
(4) a besorolási adat csak a hagyományos "heading element"-et, azaz a korai ISBD és MSZ szabványokban rögzitett tételfejet jelenti, nem pedig a teljes MARC21-rekordot.

\section{Ellenérvek}

Egyik indoklás sem igaz.

(1.1) A fentiekben már kimutattuk, hogy a besorolás nem csak azt jelenti, hogy valami konkrétat (esetünkben egy katalóguskártyát) egy rendezési elv alapján sorrendbe állitanak, elhelyeznek egy konkrét sorban (egymás mögé vagy elé, azaz sorrendben). Van egy általánosabb jelentése, amely szerint valamit egy adott fogalom terjedelmébe sorolnak be. Márpedig szaktárgyszavakkal (ahogy az osztályozási rendszerek jelzeteivel is) a forrásokat az általuk megnevezett konkrét dologhoz kapcsolják vagy az adott fogalom terjedelmébe sorolják. Ehhez nem szükséges semmiféle cédulakatalógus.

A nyelvhasználat is ezt bizonyitja:

„Hogyan érhetem el, hogy a Google minél egyszerübben besorolja az oldalamat a keresöbe?"

(1.2) Attól kezdve, hogy a MARC-formátum Magyarországon ismertté vált, az Országos Széchényi Könyvtár (OSZK) által bevezetett és használt besorolási rekord és adat minden félreértést kizárva használható volt a szakmában. 1970 óta, mióta MARC-formátumot használnak Magyarországon is (kezdetben HUNMARC formájában), senki sem emelt ellene kifogást, és nem számitott félreérthetőnek. Ha egy szabványban rögzítik, hogy az „authority data” besorolási adatot jelent, akkor teljesen egyértelmü a szakmai jelentése.

Ráadásul az MSZ 3440 besorolási szabványt csak 1979-ben adták ki. Kialakitásakor már egyrészt régen ismert volt a USMARC, másrészt már a hetvenes évektöl kezdve használták a MAMARC-ot is, majd a HUNMARC-ot a Magyar Nemzeti Bibliográfia számítógéppel történő előállitására. Magában a szabványban egyetlen egyszer nem fordul elö a katalóguscédula szó, vagy az, hogy besorolási adat alapján cédulák közé sorolják a katalógustételt. Azaz a szabvány készítői - akik közé a számítógéppel készitett Magyar Nemzeti Bibliográfia szerkesztője is tartozott - úgy hozták meg a döntésüket a szabványos „besorolási adat” megnevezéséről, hogy egyáltalán nem hagyták figyelmen kivül azt a tényt, hogy a gépesítés körülményei között már szó sincs cédulák közé sorolásról.

(1.3) A besorolási adat, vele a besorolási rekord kifejezés egyáltalán nem akadálya annak, hogy azt ne csak az ISBD és MSZ szabványokban leirt formára, hanem az újabb metaadatokat és relációkat, valamint az adatkezeléssel kapcsolatos többi metaadatot tartalmazó teljes MARC21-rekordra alkalmazzák.

Ezen se a FRAD, se az RDA nem fog változtatni, mivel csak az adattartalmat strukturálják. 
Az 1. ábrán modell szinten látható a rendeltetés szempontjából a MARC elötti és utáni helyzet.

a MARC elött:

tulajdonnév esetében a eredményhalmaza:

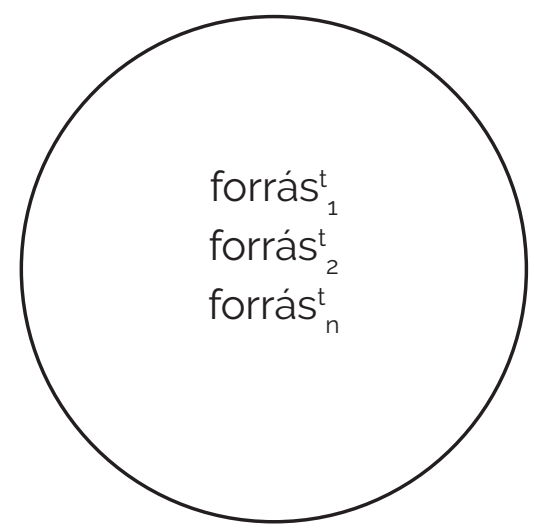

a MARC után:

tulajdonnév esetében a eredményhalmaza:

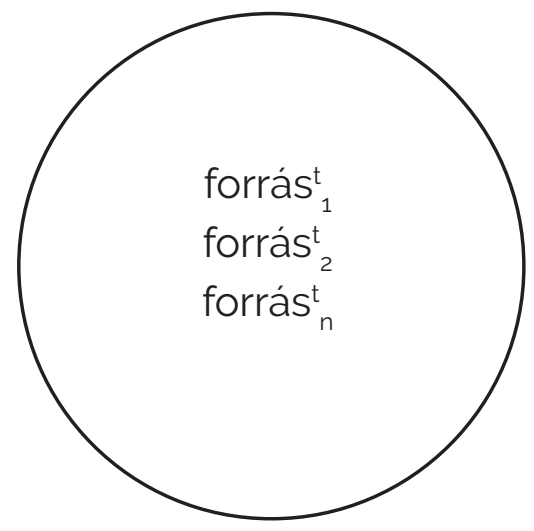

általános név (szaktárgyszó)

esetében a besorolási adat

eredményhalmaza:

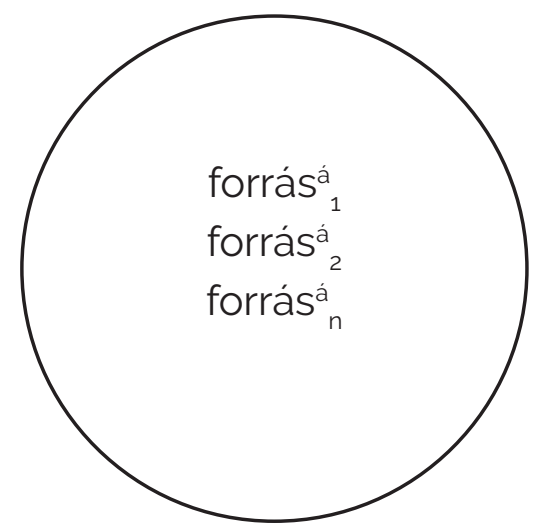

általános név (szaktárgyszó)

esetében a besorolási adat

eredményhalmaza:

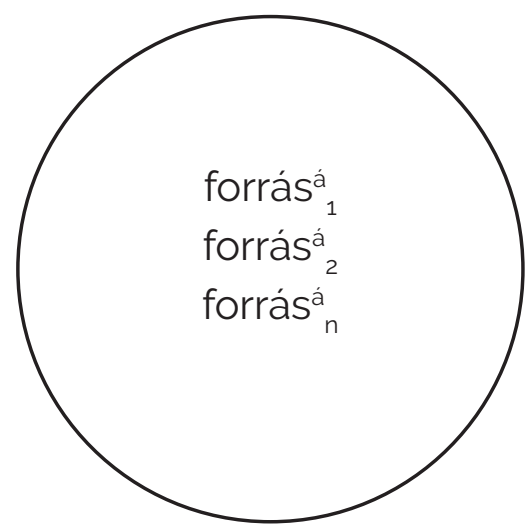

1. ábra Az „authority data", a "Normdaten" és a „besorolási adat” rendeltetési mintázata. Mindegyik esetben azonos forráshalmaz keletkezik!

Ez nem a programozás és a gépi tárolás szintje, hanem a koncepcionális modell szintje; továbbá nem a nevekröl önmagukban van szó, tehát szótárakról, névterekröl), hanem a logikai szinten létezö MARC-rekordról 
(2.1) A MARC21 „authority” rekord valóban sokkal több adatelemet tartalmaz, mint amennyit a korai ISBD és MSZ szabványokban rögzítettek - csak éppen ettöl semmit se változik a rekord szerepe. Ugyanúgy arról van szó, hogy a MARC-rekord és az ISBD és MSZ szabványos besorolási tétel lényege, hogy a rekord/tétel tételfejével indexeljenek, „tárgyszavazzanak”, osztályozzanak forrásokat úgy, hogy azok a mindenkori állományban hozzáférési pontok legyenek. Az, hogy a MAR21 esetében a tételfejen (annak rendszaván, kiegészitő adatain) kivül még számos további, a tételfejre vonatkozó metaadat is van, a tényen semmit sem változtat.

(2.2) A többletadatok valóban sokfélék. Megállapításuk valóban több munkával jár. Ez azonban egyáltalán nem változtat azon a tényen, hogy a rekord ezen adatelemei egyrészt a besoroláshoz szükséges metaadatai, másrészt pedig a besorolás eredményeként a hozzáférési pontot alkotó tételfej metaadatai ("visszajelző referenciális" adatai). Márpedig miért ne lehetnének ilyen adatok egy olyan rekordban, melyet magyarul besorolásinak nevezünk? E többlet metaadatok léte mit változtat azon, hogy a rekord továbbra is hozzáférési pontként szolgál, azaz vagy egy megnevezett fogalom terjedelmébe sorolja a forrást, vagy egy tulajdonnévhez kapcsolva sorolja azt be?

Az "egységesitett forma megszerkesztését, összevetését stb." pedig a besorolási adatok megállapitásakor ugyanúgy el kellett végezni, ezen az, hogy a MARC21-rekordban több az adatelem, semmit sem változtat, hiszen a kevesebb vagy a több adatelem megállapítása egyaránt „komplex tevékenység".

(2.3) Az „információk összeterelése”, a „nem azonosakra vonatkozók megkülönböztetése" egyáltalán nem változás a MARC elötti idökhöz képest. Ez semmi mást nem jelent, mint amit a (2.2) pontban leirtunk: hogy a besorolási/ autorizált” adattal vagy meghatározott névhez kapcsolják, vagy meghatározott, szakkifejezéssel megnevezett fogalom terjedelmébe sorolják a forrást. A "névterek integrált, szemantikus, többcélú kezelését" pedig egyáltalán nem zárja ki, hogy az adattal besorolnak, hiszen éppen az ilyen, besorolt, tehát tartalmilag egyértelmüen azonositott adattal lehetséges elvégezni ezeket a kezeléseket. A "kognitiv folyamatok" a hagyományos, ISBD szerinti besorolási adatok használata és a velük végzett keresések alkalmával is ugyanúgy lejátszódnak, mint a mostani, gépesitett körülmények között (hiszen ezek nem a külvilágban, nem a technikában, hanem az elmében zajlanak).

(2.4) Attól, hogy a szabványosságot (mert az egységesités ezt fejezi ki) különféleképpen értelmezik, és ezért még a szabványos MARC21-rekordok se teljesen egyformák ugyanazon entitás esetében, nem változik az a tény, hogy a forrásokat ezekkel a MARC21-rekordokkal besorolják. Hogy a besoroláshoz használt rekordban több vagy kevesebb „elemibb” adat (értsd adatelem) van, attól még az állítás igazságtartalma változatlan marad. 
(2.5) Tóvári Juditnak az az ellenérve, hogy „ma már egyenrangúak a névvariánsok”, azt jelenti, hogy a névvariánsok (tehát a „lásd/helyett” relációkkal kapcsolódó gépi rekordok) mindegyike - helyesen, a számitástechnika jóvoltából hozzáférési pont lehet. Azaz mindegyik szerint besorolva van a forrás adott fogalom terjedelmébe, illetve adott névhez. Akkor meg miért ne lenne használható rájuk a besorolási adat? ${ }^{3}$

(3) Attól, hogyazFRBR, FRADés RAK modellje megkülönböztetia mü, a kifejezési forma, a megjelenési forma és a példány szintjét, abból a szempontból, hogy mi a MARC21-rekord feladata, semmi se változik: ezeken a szinteken egyaránt be kell besorolni a forrást.

(4) Az angol "heading” (tételfej) valóban csak az ISBD és MSZ szabványokban rögzitett tételfejet jelenti, nem pedig a teljes MARC21-rekordot. Épen ezért kellett angol nyelvterületen a MARC-rekordok megjelenésével egy új kifejezést bevezetni. Az új kifejezés („authority”) azonban egyáltalán nem utal arra, hogy a korábbi „heading"-nél nagyobb adatról van szó. A feladata kizárólag az, hogy kizárja a MARC-rekord azonositását a tételfejjel (a "heading"gel). Csak éppen magyar nyelven nem kell a szakkifejezést megváltoztatni a MARC-rekord esetén, mert a besorolási rekord eleve nem jelenti, hogy csak tételfejröl van szó.

A MARC21 besorolási rekord tételfejen kivüli többi adatelemét azért nem kell a tételfejjel (vagy annak akárcsak egyetlen elemével is) együtt megjeleníteni hozzáférési pontként, mert azok a tételfej másodlagos avagy metaadatai. Ugyanakkor gépi rendszerben - ha olyan az adatbázis-kezelő rendszer - a besorolási rekord tetszőleges adateleme kereshetővé válik, azaz mindegyik besorolási adat lehet.

A felsorolt ellenérvekben nem általában „a magyar nyelv védelméről” van szó, hanem egy javasolt szakkifejezés történeti és szemantikai elemzéséröl. Elsösorban szakmailag érveltem amellett, hogy ez a névváltoztatás téves értelmezés eredménye.

A szaknyelv nyilvánvalóan más, mint a beszélt magyar nyelv, nem az a probléma, hogy egy kifejezés természetes nyelvü-e vagy sem. A besorolási adat is szaknyelvi kifejezés.

Az elemzéssel a döntés eredmémnyére, azaz az „autorizált” kifejezés félrevezetö voltára kivánok rámutatni szakszerü érvek alapján! Arra, hogy teljesen más okból választottak az angol-amerikai szakterületen a „heading” helyett „authority data” és „authority record" nevet, mint amit a magyar névváltoztatás javaslói állitanak. Azért

3 Azt a tényt, hogy "ma már egyenrangúak a névvariánsok” már 1998-ban Vajda Erik is megállapitotta. „Akkor" még senki se kifogásolta, hogy ezért helytelen a besorolási rekord kifejezése, és nem javasolta, hogy a besorolási rekord helyett az „autorizált rekord" kifejezést kellene használni! Ha „akkor” mindenkinek egyértelmü volt ez tény, akkor "ma”, 21 évvel késöbb (tehát több mint két évtized múlva) Tóvári Judit állítása miért érvényesebb, mint "akkor"? 
választották, mert a hagyományos angol ISBD-kifejezés (a "heading") nem volt alkalmas az új adat és rekord nevének azonositására, és nem önmagában azért, mert a MARC-rekordban sokkal több adat jelent meg, mint az ISBD-tételben, és mert összetettebbé vált a "szétszórt adatok összeterelése”. A magyar „besorolási adat" és "besorolási rekord" név ezzel szemben nem alkalmatlan arra, hogy a megnövekedett adattartalmú tételt azonositsa - mert nem pusztán tételfejet jelent - és a használatát illetően valóban továbbra is besorolásról van szó. Az telfogadott "autorizált" jelző szolgai átvétele az angolból szakszerütlen, és kritikájának jelenlegi hiánya fényt vet a könyvtári szakma jelenlegi helyzetére.

Az „autorizáció” egy másik szaknyelvben - bankszerktoréban is megjelenik, ott hitelesitést, feljogositást, felhatalmazást, engedélyezést jelent. Szakkifejezésként ma az autorizációt csak az automatán végzett kártyaművelet esetében használják, és ez megfelel a "hitelesitési” jelentésének. Azt értik rajta, hogy az elfogadó (az automata) hitelesként ismeri fela bankkártyát és engedélyezi a további müveleteket. [4] Márpedig a MARC21 tételfejei és a hozzájuk kapcsolódó metaadatok, akárcsak az ISBD "heading"-je és "heading element"-jei nem felhatalmazás, engedélyezés, hanem szabványositás nyomán keletkező adatok. Egyszerüen azért, mert itt - ahogy a szabványos tárgyszavak esetén is - szabványositásról, és nem engedélyezettségröl van szó.

A „besorolási” helyett az „autorizált” névváltozta következtében egy idő múlva a szakma új nemzedékei számára érthetetlenné válik a korábbi szakirodalomban használt, „besorolási” jelzővel ellátott összes szakkifejezés.

Németül se az autorisierte Date kifejezést használják! A német gyakorlathoz hasonlóan legfeljebb átkeresztelhetö szabványos névadatra, szabványos névrekordra:

$\begin{array}{lll}\text { authority data } & \text { Normdaten } & \text { szabványos névadat } \\ \text { authority record } & \text { Normsatz } & \text { szabványos névrekord } \\ \text { authority file } & \text { Normdatei } & \text { szabványos névállomány } \\ \text { authorized } & \text { normiert } & \text { szabványos }\end{array}$

A változtatás igy is azzal járna, hogy egy idő múlva a szakma új nemzedékei számára érthetetlenné válik a korábbi szakirodalomban használt, „besorolási” jelzővel ellátott összes szakkifejezés. A „besorolási” jelző a maga tömörségével és szépségével nyelvi telitalálat volt. Hozzáértő szakemberek hozták létre, évtizedekig nem okozott problémát, és eleve annak figyelembe vételével született, hogy a MARC (és késöbb annak magyar megfelelője) létezett.

\section{Epilógus}

Nem remélhetem, hogy ezzel az elemzéssel meg tudom változtatni a „besorolási” jelző megszüntetéséröl szóló végzetesen hibás döntést. Ennek a tanulmánynak a célja, hogy felsorolja az érveket az „autorizált” kifejezés ellen, és ezt párhuzamba állitsa azzal, hogy mekkora félreértés ez névváltoztatás. 
Amikor a múlt évben vita kezdődött a Katalisten a besorolási adat kérdéséröl, az érveimre - melyek lényegében megegyeztek azokkal, melyeket ebben az értekezésben felsoroltam - nem érkezett viszontválasz.

Azon a nemrég tartott megbeszélésen, melyen eldöntötték, hogy az „autorizált” kifejezést fogják használni, nem vehettem részt, érveimet nem adhattam elő.

\section{Irodalom}

[1] Dudás Anikó. Az autorizálás az információszervezés és -hozzáférés feladatkörében - definiálás és nemzetközi tapasztalatok. = Könyvtári Figyelö, 52. évf. 4. sz. (2006). http://www.ki.oszk.hu/kf/kfarchiv/2006/4/dudas. html\#top

[2] Dudás Anikó: Nevek, antik nevek - autorizálás: egy magyarországi felmérés eredményei. = Tudományos és Müszaki Tájékoztatás, 52. évf. (2005) 9. Sz.

[3] Dudás Anikó: Forrásleírás és hozzáférés. Az új angol-amerikai katalogizálási szabályzat (RDA) és kritikája. = Könyvtári Figyelö, 2013. január 3. 4. sz.

http://ki2.oszk.hu/kf/2013/01/forrasleiras-es-hozzaferes-az-uj-angolamerikai-katalogizalasi-szabalyzat-rda-es-kritikaja/

[4] Gál Erzsébet: Hitelkérelmek, banki ismeretek. 4.3.3. Autorizáció (felhatalmazás) folyamata. (2013) https://www.tankonyvtar.hu/en/tartalom/ tamop412A/o007_d3_hitelkerelem_jav_scorm/4_3_3_autorizacio_ felhatalmazas_folyamata_knqQLg6m4m260Xpo.html

[5] HUNMARC, a besorolási rekordok adatcsere-formátuma. Összeáll. Sipos Márta, Szabó Julianna, Ungváry Rudolf. Budapest, 2010. Tervezet.

[6] HUNMARC, a besorolási rekordok adatcsere-formátuma. Összeáll. Sipos Márta. Budapest, 1998 március. Tervezet.

[7] KSZ/4.1 HUNMARC. A bibliográfiai rekordok adatcsere formátuma. [Összeáll. Sipos Márta]. Budapest, 2002. március.

http://www.ki.oszk.hu/107/e107_files/public/hunmarc.pdf

[8] Katalist. [Vita az „autorizált” jelző alkalmazásáról] [Dancs Szabolcs és Tóvári Judit hozzászólásal. 2018. augusztus 24. http://katalist-to-feed.blogspot. com/2018/08/re-katalist-uj-rendszerhez-uj-zsargont_30.html https://listserv.niif.hu/pipermail/katalist/2018-August/038933.html https://listserv.niif.hu/pipermail/katalist/2018-August/038886.html 
Köznevelés, felsöoktatás, elektronikus tanulási környezetek 
Digitalizáció és sport: az IKT kihívásai a testnevelő képzésben

\author{
Antal Péter \\ Eszterházy Károly Egyetem, Médiainformatika Tanszék \\ antal.peter@uni-eszterhazy.hu
}

\begin{abstract}
Digitalization and Sports: ICT-related challenges in Physical Education teacher training

The principal challenge of the 21st century is the digitalization process requiring the educational sphere to meet the demands of the new instructional environments. While digital devices have been virtually fully integrated in the instruction of natural science or humanities subjects, different expectations apply to Physical Education teachers as digital boards do not play a significant role in such instruction programs. At the same time the increasing prevalence of digital and communication technology both in competitive and recreational or amateur sports calls for the instruction of new competences in Physical Education training programs.
\end{abstract}

Suffice to mention portable analytical devices assessing and analyzing the actual state and the changes of athletes' physiological conditions in real time and in real contexts. Furthermore, tactical analysis, efficiency surveillance, or movement analysis programs along with devices monitoring performance and physiological conditions pervading non-professional sport as well can provide crucial help to athletes and coaches. Since students enrolled in Physical Education teacher training programs are expected to have different ICT skills from their other colleagues in the profession special training schemes are required for them.

My presentation at the juncture of sports and ICT introduces the information technology aspects of the Physical Education teacher training programs at Eszterházy Károly University and compares the results of a survey performed among Physical Education teachers with that of the international trends.

Keywords: ICT, Digitalization, Sport, Performance, Competences.

\title{
Bevezetés
}

A 21. század a digitalizációról szól, melynek fontos kihivása, hogy az oktatás is megfeleljen az új oktatási környezetnek. Mig a természettudományos vagy humán tantárgyak esetében egyre természetesebb a digitális eszközök használata addig a testnevelés tárgy oktatásában teljesen mások az elvárások, hiszen a digitális tábla, mint eszköz, nem játszik fontos szerepet egy testnevelő repertoárjában. Ezzel szemben a digitális- és kommunikációtechnológia hihetetlen mértékben beszivárgott a verseny- és amatőr sportba egyaránt és új kompetenciák igényét generálja a testnevelők felkészitésében.

Gondoljunk csak azokra a hordozható analitikai eszközökre, amelyek, a sportolók fiziológiai állapotának, változásait valós idöben, valós körülmények között képesek mérni és analizálni. Ugyanilyen fontosak a taktikai elemzéseket végző, 
hatékonyságot figyelö, vagy mozgáselemzö programok, vagy amatör sportban is használt teljesítményt és fiziológiai állapotot monitorhozó eszközök, amelyek segithetika sportolók és edzök munkáját. Éppen ezért fontos a testnevelő képzésben résztvevő hallgatók, speciális felkészitése, hiszen teljesen más IKT eszközökkel kerülnek szembe, mint a közoktatás egyéb szereplöi.

Előadásomban a testnevelő szakos hallgatók információtechnológiai felkészitését és képzési rendszerét mutatom be, az Eszterházy Károly Egyetemen, illetve egy testnevelök körében végzett felmérés eredményeit hasonlítom össze a nemzetközi trendekkel a sport és IKT témakörében.

\section{A globális sporttechnológiai piac alakulása a napjainkban}

A Transparency Market Research által közzétett új piaci jelentés szerint 2016-ban [6] a globális sporttechnológiai piacot 21.609 millió dollárra értékelték. Ez az érték a becslések szerint, 2019 és 2027 között 14,7\% -os éves növekedési rátával számolva, eléri a 93.825 millió dollárt 2027-re. Ez elsösorban a technológiai fejlesztésektöl és a sporttechnológiai háttér informatikai támogatásának a növekedésétöl függött, föleg a kiemelt sportok körében.

A legkeresettebbek, az analitikai megoldások, a hordozható eszközök, a csapatmenedzsmentettámogatóalkalmazások,azegyénisportolóiteljesítményeket és a csapatteljesítmény adatait feldolgozó szoftverek és szolgáltatások.

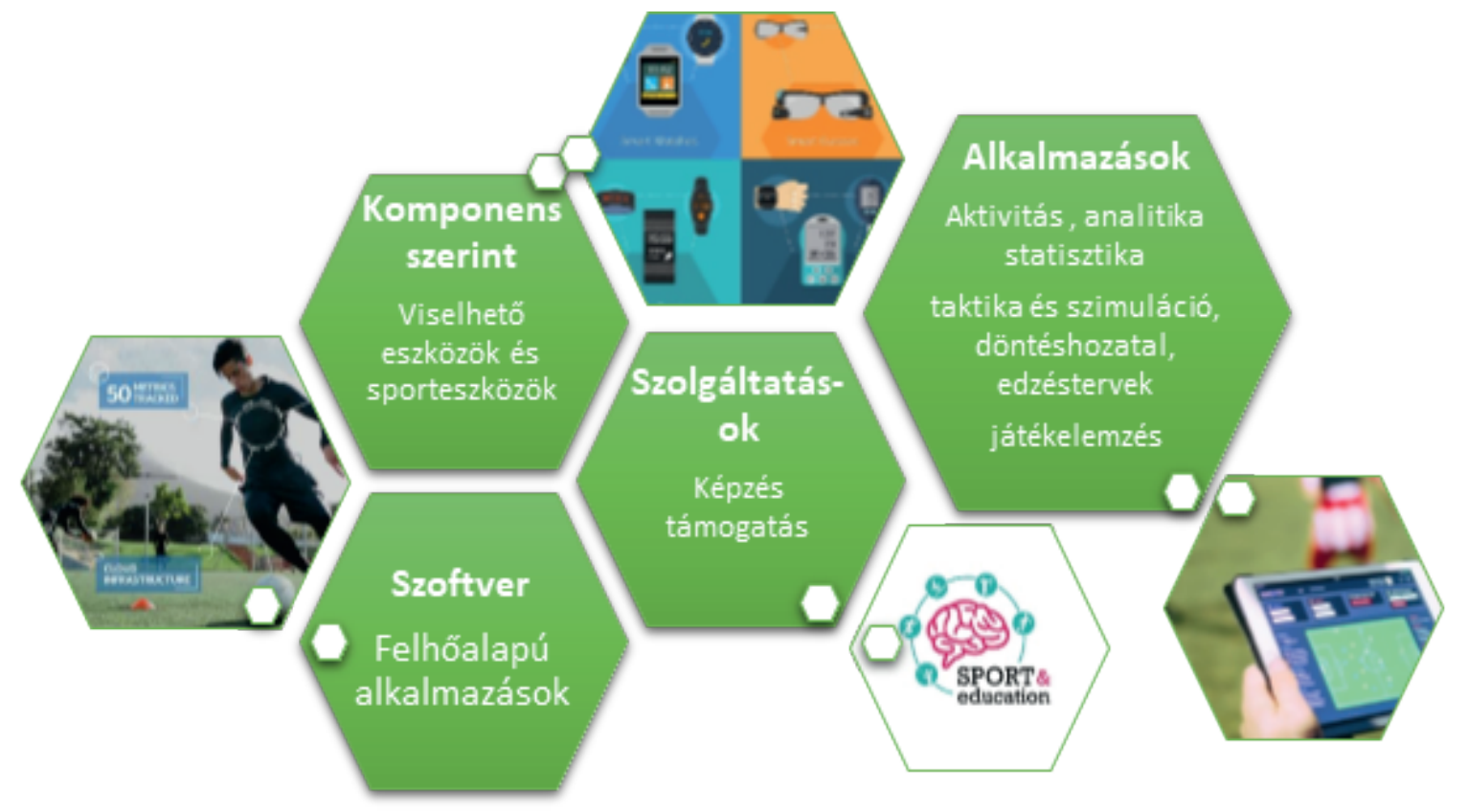

1. ábra: A sporttechnológiai piac összetevői 
A sporttechnológiai piac összetevőit többféle szempontból elemezhetjük.

- Komponens szerint

- Viselhető eszközök és sporteszközök

- Szoftver

- Felhöalapú alkalmazások

- A helyszini adatfelvétel

- Szolgáltatások

- Képzés és megvalósítás

- Támogatás és karbantartás

- Irányitott / kiszervezett szolgáltatások

- Alkalmazás szerint

- Aktívitás követés

- Analitika és statisztika

- Taktika és szimuláció

- Döntéshozatali támogatás

- Edzéstervek

- Játék teljesitmény elemzése

- Csapatelemzés és -kezelés

- Sérülés és egészségügyi elemzés

A fent látható portfólióból kiderül, hogy a sport és a technológia összefonódása egyre intenzivebb folyamat lesz, gyakorlatilag a jövö egyik leghasznosabb teljesitménynövelő eszközévé maga a technológia válik.

Ezen belül a viselhetö eszközök jelentik majd a legnagyobb piacot, hiszen ezek közvetlenül tudnak majd adatokat szolgáltatni az elemzöknek. Az Ericsson cég 2016-os kutatásai szerint [5], 2020-után éri el a technológia azt a szintet, hogy komoly orvosi diagnosztikára is alkalmasak lesznek, akár a mobiltelefonokat is helyettesiteni tudják. Megjelenik a viselhető eszközök internete, ami segit a felhasználóknak interakcióba kerülni más fizikai tárgyakkal, ami nem feltétlenül eszközöket jelent. A felhasználók 60 százaléka gondolja úgy, hogy a következö öt év során a tabletták és a bör alá ültetett chipek el fognak terjedni - és ezek nemcsak az egészségügyi adatok nyomon követésére lesznek használhatók, hanem ajtók nyitásához, tranzakciók és személyazonosság hitelesitéséhez, és tárgyak vezérléséhez. Már ma is az okostelefon-használók 25 százaléka használja az okostelefonját arra, hogy távolról vezéreljen digitális eszközöket otthonában, és 30 százalékuk használ hangalapú keresést az okosóráján. 


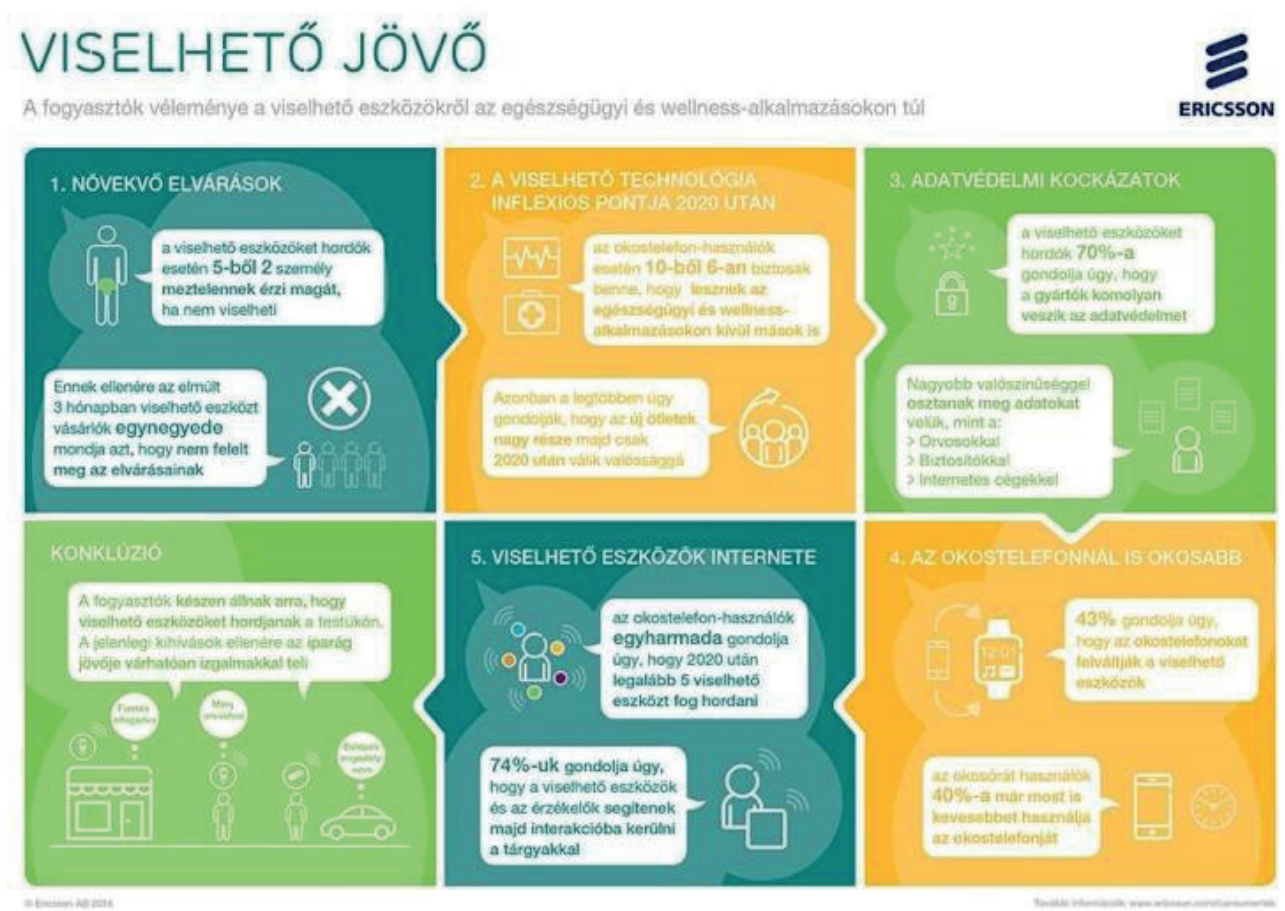

2. ábra: A viselhető jövő trendjei [5]

\section{A technológia szerepe a testnevelés oktatásában}

Atechnológiajelenlététés szükségességétasportban ma márnem kérdőjelezhetjük meg és a bevezető részböl is kiderül, hogy a profi sport már kihasználja ezeket a lehetöségeket. A testnevelö képzésben viszont komoly elmaradások vannak a viselhető eszközök iskolai alkalmazásának módszertanában [3].

Még Európában is ritkák azok a kezdeményezések, ahol a közoktatásban használnák $\mathrm{ki}$ a viselhetö eszközök lehetőségeit. Egyik ilyen példa a spanyolországi BarcelonaPárizs virtuális futás tapasztalatai [2], Illetve hasonló még az olaszországi "The Portable Devices as Means to Promote Children's Active" kisérlet, amely a gyerekek iskoláig történő gyaloglását próbálta meg segiteni és inspirálni mobil alkalmazás segitségével. [1]

Magyarországon az utóbbi években kiemelt szerepet kapott az iskolai tevékenységekben a testmozgás, hiszen a 2011/12-es tanévtöl, heti 5 órában, kötelező a mindennapos testnevelés a hazai közoktatási intézményekben, melynek eredményessége fontos a felnövekvő nemzedékek szempontjából. A Magyar Diáksport Szövetség 2013-ban inditotta útnak a "A testnevelés új stratégiájának és a fizikai állapot új mérési rendszerének kialakitása és az önkéntes részvétel ösztönzése a komplex iskolai testmozgásprogramok szervezésében" -T.E.S.I. elnevezésü kiemelt projektjét. 
A projekt célja volt, hogy létrehozza a magyar iskolarendszerben egységesen müködtethető, egészségközpontú fittségmérési-értékelési rendszert, a NETFIT-et. A NETFIT szoftveres alkalmazása olyan személyre szabott értékelési lehetőséget kinál minden tanuló számára, amely vizuálisan is szemlélteti a fittségi állapotot, valamint konkrét ajánlásokat fogalmaz meg a fejlesztés érdekében. A NETFIT rendszert közel 3700 iskola, 800 ezer tanuló és 13 ezer pedagógus használja. A rendszer hatékony használatához elengedhetetlen a testnevelők részéröl a nyitottság a digitális kompetenciák megszerzésére. A testnevelő képzésben viszont nem történik meg a felkészités a rendszer használatára [4].

\section{IKT innováció a testnevelö képzésben}

A fenti trendekböl jól látszik, hogy egy nagyon dinamikusan fejlödö informatikai szegmenssel van dolgunk, amit a képzési struktúra sem hagyhat figyelmen kivül.

Az Eszterházy Károly Egyetemen korábban is volt a testnevelök részére a technológiát oktató kurzus, Oktatás- és kommunikációtechnológia néven, de ez elsősorban a tanári pályán általánosan elöforduló IKT eszközök használatára és módszertani lehetőségeire korlátozódott.

A 2017/18-as tanévtöl azonban kísérleti jelleggel elinditottunk egy speciális kurzust új tartalommal a testnevelők részére IKT innovációk néven.

A kurzus célja, hogy megismertesse a hallgatókat a 21. század IKT eszközeinek hatékony alkalmazásához szükséges ismeretekkel, különös tekintettel azok sport és rekreációs tevékenységek során történő alkalmazására. Fontos az új sporttechnológiák és módszerek megismertetése a hallgatókkal, illetve ezek alkalmazási módszertanának kidolgozása a szakiránynak megfelelően.

A kurzus két kredit értékü, heti két órás gyakorlatot takar egy féléven keresztül.

A legfontosabb témakörök a következök:

- Az információs és kommunikációs technológiák (IKT) hatása a 21. században

- Az IKT fogalomrendszere, az információs- és hálózattársadalom alapjai

- A21. század kommunikációs és oktatási formái: az elektronikus tanulási környezet fogalomrendszere.

- A technológiák alkalmazási lehetöségei az amatör és versenysportban (sportanalitikai, teljesitményelemző rendszerek)

- Viselhető technológiák, kreativ médiatechnológiák (okoseszközök használata a sport és a rekreációs tevékenységek során.

- Az iskolai alkalmazás eszközei és szoftverei, adatmegosztás a felhöben

- A hordozható eszközökre épülő ismeretelsajátítás, mobil kommunikációs eszközök és a tartalomipar, és az iskolai teljesitménymérés lehetőségei

- Személtetés, szemléletesség. Az elektronikus publikáció sajátosságai, a prezentálás alapjai.

- On-line prezentációkészités- Prezi a gyakorlatban

- A digitális technológiára épülö kutatástervezés alapjai. 


\section{A tantárgy relevanciájának vizsgálata}

A tantárgy tartalmi relevanciájánakés a hallgatói vélemények mérésének érdekében egy kérdőives felmérést és mini interjúk készitését végeztem el a nappalis és levelező hallgatók körében, összesen 38 fö válaszolt.

Akérdöiveskérdésekahallgatóktechnológiaitájékozottságára, azeszközhasználatra, illetve a tantárgyi relevanciára vonatkoztak.

A miniinterjúk során elsősorban arra a kérdésre voltam kiváncsi milyen ismeretekkel rendelkeznek azok a hallgatók, az információs társadalomról és annak hatásairól, akik a koruk alapján már a digitális bennszülöttek táborába tartoznak.

A beszélgetés témakörei a következök voltak:

1. Ön szerint milyen hatással van a technológiai fejlődés a korosztálya életére (proés kontra).

2. Hogyan képzeli el a modern technológiák felhasználását a saját sportágában?

4. Milyen hatással van média a sportra, és a sport a médiára, milyen elönyök, hátrányok származnak ebből?

6. Hogyan képzelik el a jövő IKT eszközeit? Mit gondol milyen új eszközök fognak megjelenni?

8. Hogyan segitheti a sportot a technológia, milyen eszközöket látnának szivesen, illetve hogyan tudnának ezek segiteni a sportban?

10. Hogyan ítélik meg, hogy általános- és középiskolában illetve a felsőoktatásban felkészitették-e Önöket az információs társadalom kihivásaira és megfelelő szintünek tartják-e ezt?

Jelen cikkben csak a legérdekesebb kérdéseket elemzem a következőkben.

\section{A kérdöiv eredményei}

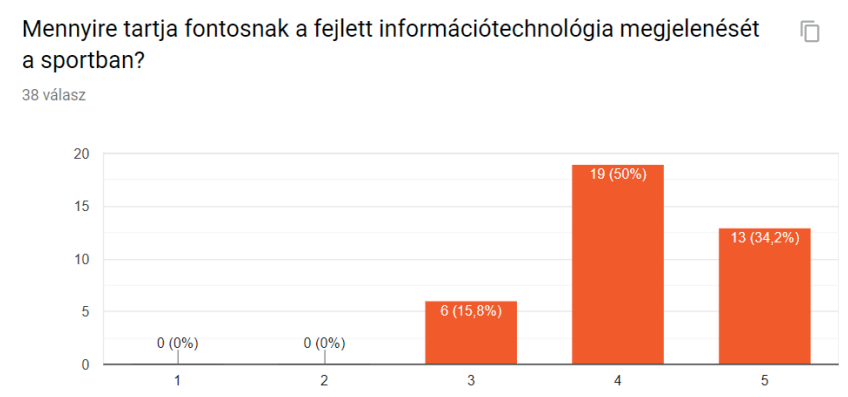

A kérdésre mindenki pozitiv választ adott, gyakorlatilag a hallgatók $80 \%$-a érzékeli a modern technológiában rejlő lehetőségeket, hogy segitséget nyújthat a sportban. Amint az eredményböl látszik, még mindig van 20\% akik elutasitják a technológiai vivmányok használatát a sportban. Ennek oka többféle lehet, az elutasitók többsége olyan eszközökre gondolt, amelyek illegálisan segitik a sportolókeredményességét, illetve nem élsportolók és nem látták bizonyitottnak a technológia szükségességét a sportágukban. 
Használ(t) -e valamilyen okos eszközt sporttevékenység közben? 38 válasz

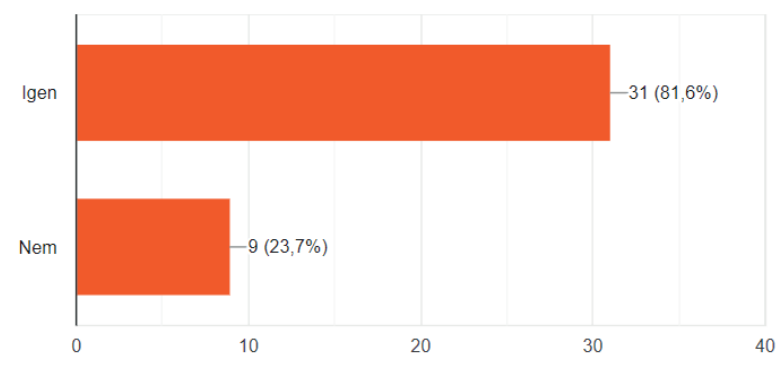

Az eszközhasználattal kapcsolatban is pozitiv a hallgatók véleménye, sokan használtak vagy használnak viselhetö eszközöket. Legtöbbjük okosórát, testszenzort használt már telefonnal tablettel kombinálva. Speciálisabb eszközöket (okosruha, okoscipő, kardiológiai adatokat mérö) eszközöket azonban nem. Az is kiderült, hogy nem mindenki alkalmazza öket megfelelően, illetve nem használja ki ezek lehetőségeit maximálisan, ami elsősorban abból adódik, hogy nem is ismerik megfelelően az eszközöket.

Milyen motiváló erővel hathat a technológia használata a sportban? 38 válasz

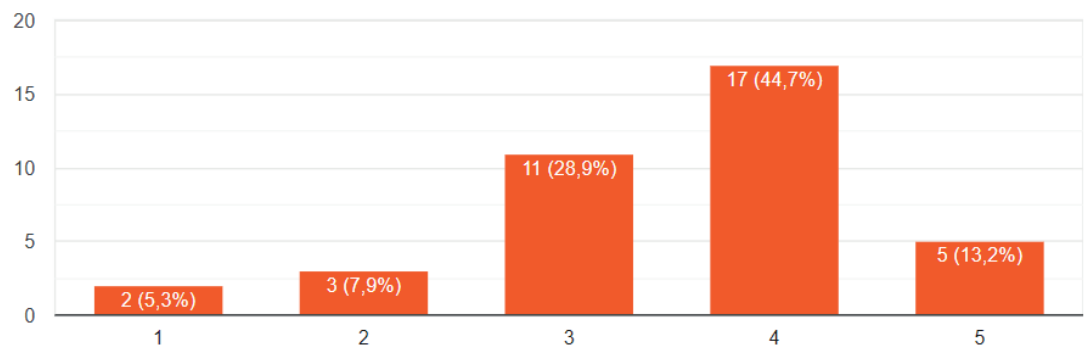

Arra a kérdésre, hogy van e motivációs ereje a viselhető eszközöknek a sportban zömében pozitivan válaszoltak, elsösorban a gyors feedback-et jelölték meg pozitivumként. A kicsit szkeptikusok inkább az eredmények megbízhatóságát vonták kétségbe, vagyis nem bíznak az eszközök pontosságában, aminek szintén lehet alapja.

Fontosnak tartja- e a testnevelő képzés technológiai irányú fejlesztését a jövőben?

38 válasz

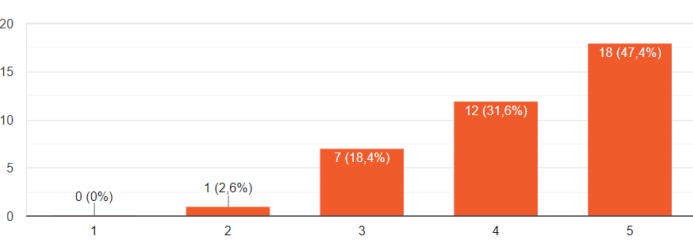

Fontosnak tartja- e a korszerú teljesítménymérō és analitikai eszközök, programok megismerését az egyetemi képzésben? 37 válas

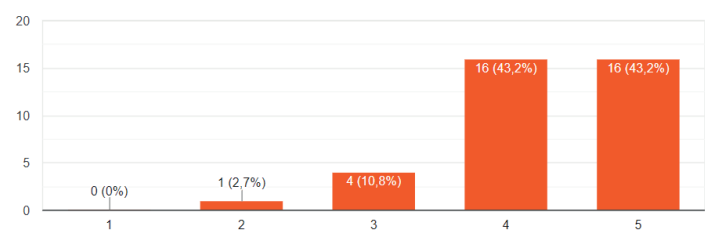


A képzés relevanciájára és tematikájára vonatkozó kérdések közül mindkettöre pozitivan reagáltak. A válaszadók mindkét esetben $70 \%$ felett nyilatkoztak a képzés technológiai megújítása és ezek megismerésének fontosságát illetően.

\section{A miniinterjú eredményei}

A mininterjúkérdései közül a két legérdekesebbet emelném ki, amelyek a digitális világ kihivásait boncolgatja.

1. Ön szerint milyen hatással van a technológiai fejlödés a korosztálya életére (proés kontra)?

A válaszok nagyon eltérőek voltak, és nem biztosak a technológia mindenhatóságában nagyon furcsának és ellentmondásosnak tartják azt a világot melyben élnek.

Volt, aki azt nyilatkozta a "tamagochi én magam vagyok" minden percét az elektronikus naptárja szerint éli szervezi. Volt, aki azt emelte ki, hogy a szük időbeosztás mellet nagyon kedveli az elektronikusan elérhető tananyagokat, hiszen idöben és térben független lehet a tanteremtöl. Akadt olyan válasz is, aki a közösségi oldalalak szerepét emelte ki elsösorban azt, hogy példaképeit tudja követni és ez inspirálja öt is nagyobb teljesitményre.

2. Eddigi tanulmányaik során felkészitették-e Önöket az információs társadalom kihivásaira és megfelelő szintünek tartják-e ezt?

Az egyéni felkészültségük szintjérölaz információs társadalomban nem nyilatkoztak pozitivan, sokan érzik az eddigi felkészültségüket hiányosnak, nem ismernek igazán jó, megbizható információforrásokat, jellemzően gyors célirányos kérdésekre kevesen kapnak releváns választ, nem tanulták a keresési stratégiákat, kevés olyan alkalmazást ismernek, amely megkönnyiti az életüket. (Pl: Neptun rendszerröl órarend szinkronizálása mobilra.)

\section{Összegzés}

A kutatás eredményei bizonyitják, hogy érdemes a testnevelö képzésben az információ technológiai kérdésekkel foglalkozni, hiszen ezek az életük részei és mint kiderült, nagyon sok hallgatónak van mit pótolnia a kérdéskörben. Felmerül a kérdés ha bele tudjuk csempészni a mobiltechnológiát az iskolai testnevelés órákra is, lesz e motiváló hatása a mobil eszközök használatának az iskolai testnevelés órákon, illetve lesz- e ennek pozitiv következménye? Például egy virtuális Balaton körbefutás során, ahol csapatban mindenki digitális térképen megjelenítve tudja majd a saját teljesitményét a többiekkel megosztani. Ezek a kérdések még nyitottak mindenképpen megéri kipróbálni őket. 
Irodalom

[1] ARDUINI, BORGOGNI, CAPELLI (2016): The Portable Devices as Means to Promote Children's Active Lifestyle: The Case of a Walk To School Action in Italy in: Physical Education and new technologies (2016) szerk: Novak, Antala, Knjaz, Zagreb 2016. pp: 19-25. ISBN: 978-953-7965-05-1

[2] ARÉVALO, HERNANDO, MÓN, CATASÚS (2016): Physical Education And Ict: An Unstoppable Combination in: Physical Education and new technologies (2016) szerk: Novak, Antala, Knjaz, Zagreb 2016. pp: 61-69. ISBN: 978-9537965-05-1

[3] KNJAZ, RUPČIĆ, ANTEKOLOVIĆ (2016): Application of Modern Technology in Teaching and Training with Special Emphasis on Basketball Contents in: Physical Education and new technologies (2016) szerk: Dario Novak, Branislav Antala, Damir Knjaz, Zagreb 2016. pp: 112-113 ISBN: 978-953-7965-05-1

[4] NETFIT koncepció: A 2015/2016. tanév NETFIT mérés eredményei tudományos elemzése

https://www.netfit.eu/public/pb_media.php?media=dokumentumok (2019. 09.07.)

[5] A viselhetö eszközök trendjei: https://www.ericsson.com/49e8cf/assets/ local/trends-and-insights/consumer-insights/consumerlab/infographs/ wearable-technology-infograph-ericsson-consumerlab-2016.pdf (2019. 09.07.)

[6] Sports Analytics Market - Global Industry Analysis, Size, Share, Growth, Trends and Forecast 2018 - 2026

https://www.transparencymarketresearch.com/sports-analytics-market. html (2019. 03.06) 


\title{
Az informatikai gondolkodás (computational thinking) fogalmi keretei
}

\author{
Csernai Zoltán \\ Eszterházy Károly Egyetem \\ csernai.zoltan@uni-eszterhazy.hu
}

\section{The conceptual framework of computational thinking}

The Fourth Industrial Revolution radically changes the system of abilities and skills expected of the citizen of the 21st century. As priorities are shifted from knowledge to competence heretofore unseen demands emerge at the labour market. One of the current priorities is the improvement of STEM competences, that is, the acquisition of knowledge and skills related to (S)cience, (T)echnology, (E)ngineering, and (M) athematics via interdisciplinary and transversal instruction schemes.

According to experts the demand related to STEM competences and skills is expected to increase. Analysts forecast a 3\% overall growth in employment in the EU until 2020, and this figure could reach up to 9\% in STEM-impacted professions (Szegedi, 2014). Simultaneously computational thinking (Wing, 2008) is gaining increasing popularity as an umbrella term for the aforementioned four areas.

Subscribing to a deductive approach utilizing a specifically elaborated criteria system, I explore various interpretations of the given concept in the international community. Furthermore, I will analyse the respective manifestations in the DigComp 2.1. framework system (Carretero, Vuorikari \& Punie, 2017) approved by the European Union.

This effort is a preliminary stage for further inquiry into the domestic situation especially the examination of the documentation of specific education management initiatives [MDOS, 2016 (Digital Education Strategy of Hungary); NAT (National Curriculum) 2018].

In the next phase of my research I will explore computation thinking-related attitudes in teacher training by the combined paradigm method (Sántha, 2014) My research tools include a self-developed measurement device along with questionnaires and interviews as well.

Keywords: Computational thinking, DigComp 2.1

\section{Problémafelvetés}

A 4. ipari forradalom hatására megváltozik a 21. századi állampolgártól elvárt képességek rendszere, a tudásról egyre inkább a kompetenciákra helyezödik a hangsúly, a munkaerőpiacokon a korábbitól eltérő elvárásokjelennek meg. Napjaink egyik fő irányvonala a STEM területek fejlesztése, amelya (S) természettudományos, a (T) technológiai, a (E) mérnöki tudományokat és a $(M)$ matematikát helyezi elötérbe, annak interdiszciplináris és transzverzális oktatása révén. 
A STEM területekhez kapcsolódó képességek iránti kereslet ugyanis növekedni fog, az elemzök az 2020-ig az EU-ban átlagosan 3\%-os foglalkoztatottsági növekedés várnak, a STEM és a társult szakmákon belül ez az érték $9 \%$ lehet. ${ }^{1}$

A digitális gazdaság és társadalom fejlettségét mérő DESI-index (Digital Economy and Society Index -DESI) azt vizsgálja, hogy mennyire állnak készen az Európai Unió tagállamai a digitális átállásra.

ADESI egyik pillére (2. Humán töke) azt méri, hogyaz egyénnek milyen képességekre van szüksége a digitális társadalomban való boldoguláshoz, amelyhez az alábbi indikátorok szükségesek (1. ábra):

Internetfelhasználók

Alapvető digitális készségek

IKT-szakemberek

STEM diplomások

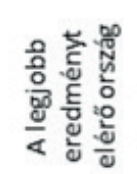

DESI 2018 Relatív teljesítmény dimenziónként

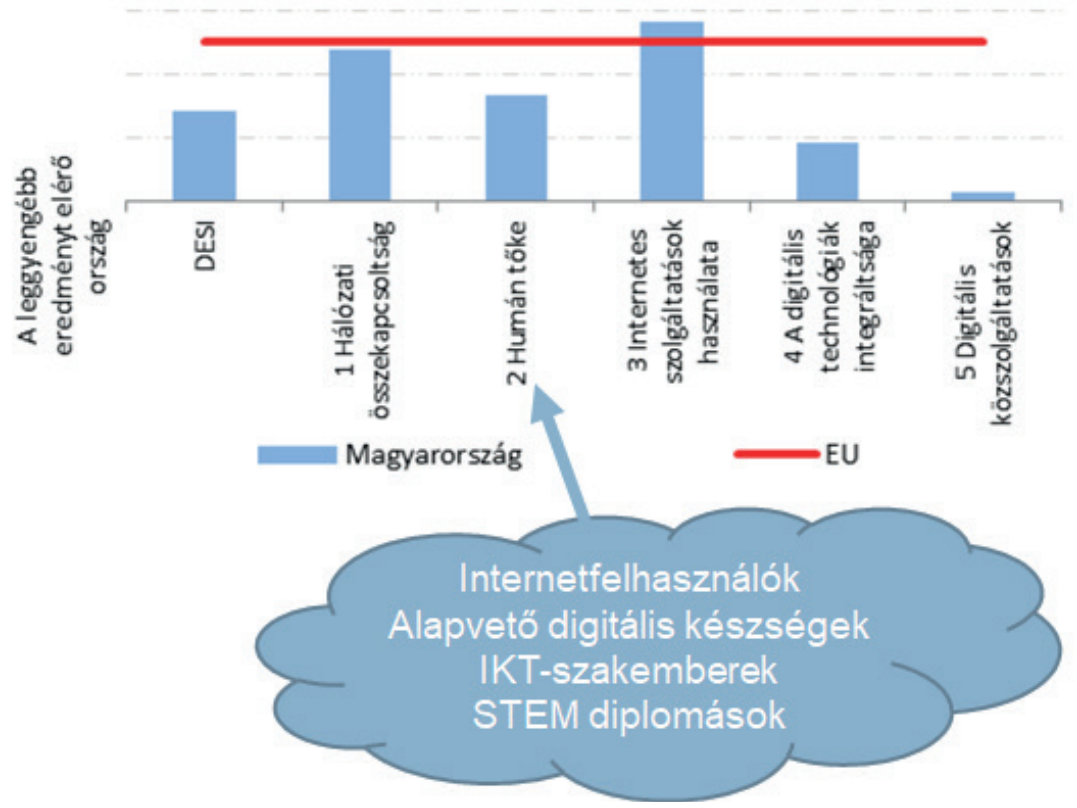

1. ábra: A digitális gazdaság és társadalom fejlettségét mérő mutató (DESI), 2018, Magyarországról szóló országjelentés

(Forrás: Digital Economy and Society Index 2018 - Magyarország. URL: http://europa.eu/rapid/press-release_MEMO-18-3737_en.htm)

1 Szegedi Eszter. "Miért került világszerte fókuszba a STEM területek oktatása?" pp. 9-14., 2014. http://tka.hu/docs/palyazatok/belestem.pdf 
Az oktatás digitális átállása ugyan elkezdődött, azonban nincsen egységes fogalomkészlete. Bizonyos esetekben, tévesen szinonimaként utalnak az emberek az informatikai gondolkodásra, a digitális kompetenciára és az algoritmikus gondolkodásra.

Kutatásom célja, hogy deduktiv módon megvizsgáljam, hogy nemzetközi szinten hogyan értelmezik e fogalmat, és egy kidolgozott szempontrendszer alapján elemezzem az Európai Unió által elfogadott ${ }^{2}$ keretrendszerben való megjelenését.

A Computational Thinking fogalmának értelmezései

A Computational Thinking (CT) fogalmát a nemzetközi szakirodalomban nem egységesen értelmezik, többnyire a fogalom egyes részterületeiben rejlö fejlesztési lehetőségekre fókuszálnak. Kutatásom során a CT fogalmi fejlődésének legfontosabb állomásait mutatom be. (2. ábra)

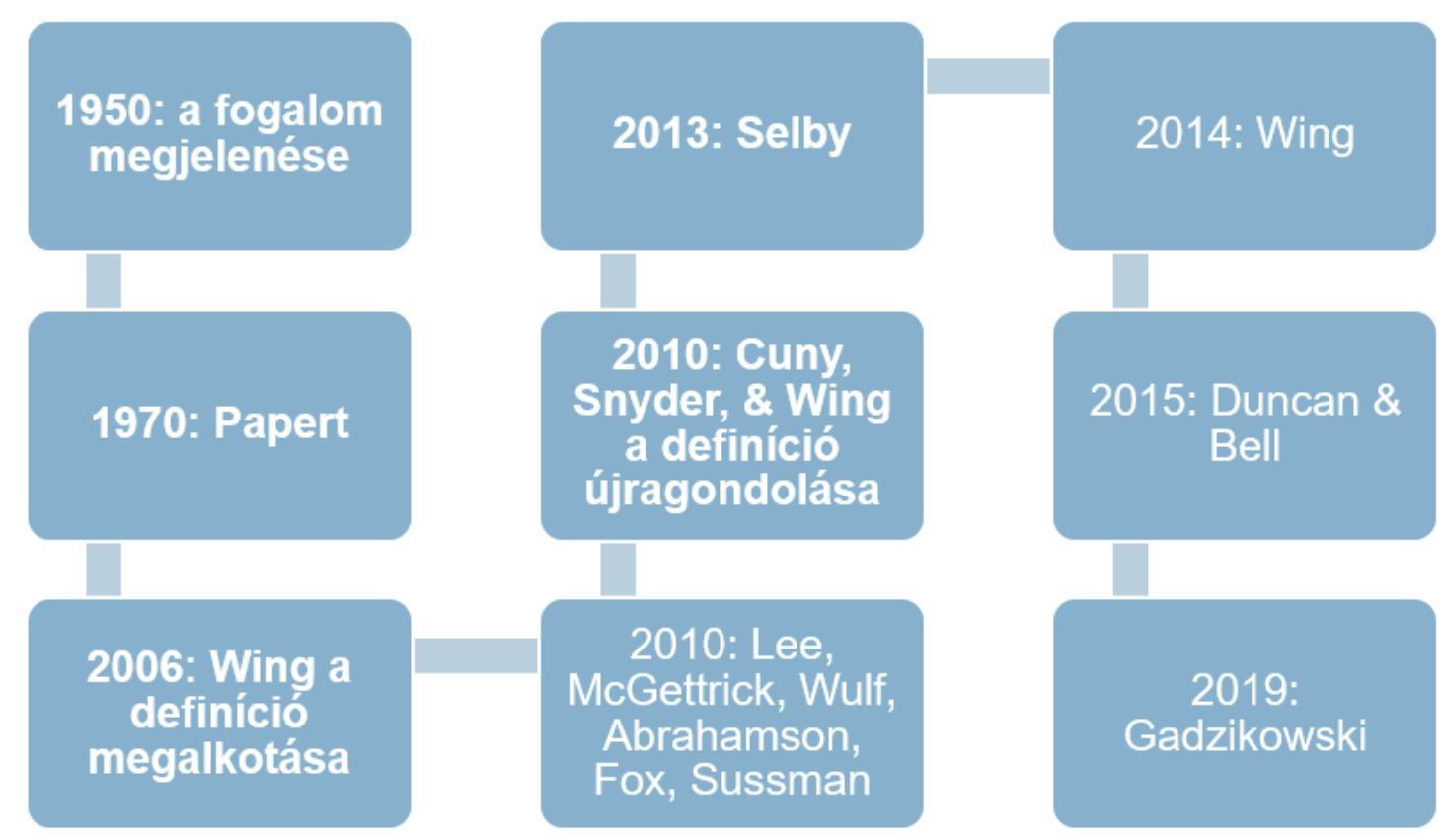

2. ábra: A Computational Thinking (CT) fogalom „evolúciójának" legfontosabb állomásai (Forrás: a szerző saját ábrája)

Az 1950-es években jelent meg a CT fogalma a számítógép-tudomány jellemzöjeként. Az 1970-es években Seymour Papert, az MIT professzora, a Logo programozási nyelvet a CT-n keresztül mutatta be a diákoknak.

\footnotetext{
$2 \quad$ Stephanie Carretero, Riina Vuorikari, Yves Punie. "DigComp 2.1: The Digital Competence Framework for Citizens with eight proficiency levels and examples of use." Luxembourg, Sweden: Joint Research Centre of the European Commission, 2017. http://publications.jrc.ec.europa.eu/repository/bitstream/JRC106281/web-digcomp2.1pdf_ (online).pdf
} 
A Computational Thinking fogalmát Jeanette Wing a 2006-ban megjelent cikkében határozta meg. Véleménye szerint az informatikai gondolkodás magába foglalja a problémák megoldását, a rendszerek tervezését, és az emberi viselkedés megértését, a számítástudomány alapelvei alapján. ${ }^{3}$

Jeanette Wing meg van arról győződve, hogy a XXI. század közepére az irás, az olvasás és a számtan mellett az informatikai gondolkodás megjelenik, mint a 4. alapvető készség.

Jeanette Wing a CT fogalmát 2010-ben újragondolta, és megalkotta az egyik leggyakrabban idézett meghatározást, miszerint az informatikai gondolkodás a problémák megoldására irányuló gondolkodási folyamat, amely segíti, hatékonyabbá teszi az információ feldolgozásának müveletét. ${ }^{4}$

Cynthia C. Selby értelmezésében az informatikai gondolkodáshoz szükséges képességek: absztrakt fogalmakban gondolkodás, részekre bontás a gondolkodás során, algoritmikus gondolkodás, értékelésben való gondolkodás és általánositás képessége a gondolkodás során. ${ }^{5}$

Gerald Jay Sussman professzor meghatározása alapján az informatikai gondolkodás szigorú elemzést és eljárásokat foglalmagában egy meghatározott feladat hatékony végrehajtásához. ${ }^{6}$

Ann Gadzikowski kutatási alapján az informatikai gondolkodás négy készségkategória kombinációja: mintafelismerés, algoritmusok létrehozása és használata, elemi részekre bontás, az absztrakciók megértése. ${ }^{7}$ A mintafelismerés során az óvodások elsajátítják az alakzatok formák és színek szerint történő szétválogatását. Az algoritmus szó valamilyen müveletsort, tevékenységet jelent, amellyel egy adott probléma megoldását adjuk meg. Olyan egyszerü feladatok megoldására kell itt gondolni, mint pl. egy gomb felvarrásának vagy egy pite sütésének lépései. Az elemi részekre történő bontással pl. a matematikában találkozhatunk, amikor egy háromjegyü számot helyiérték szerint fel kell bontanunk százasokra, tízesekre és egyesekre. Az absztrakciók megértése magában foglalja az általánositások

3 Jeannette M. Wing. "Computational Thinking," Communications of the Association for Computing Machinery Viewpoint, March 2006, pp. 33-35.

http://www.cs.cmu.edu/ ./15110-s13/Wingo6-ct.pdf

$4 \quad$ Jan Cuny, Larry Snyder, and Jeannette M. Wing. "Demystifying Computational Thinking for Non-Computer Scientists" work in progress, 2010.

$5 \quad$ Pluhár, Zsuzsa és Torma, Hajnalka és Törley, Gábor. "Hallgatói teljesitményértékelés az algoritmikus gondolkodás tükrében." In: InfoDidact 2018. Webdidaktika Alapítvány, Budapest, pp. 1-10., 2019. http://real.mtak.hu/g2129/

$6 \quad$ National Research Council. "Report of a Workshop on the Scope and Nature of Computational Thinking." Washington, DC: The National Academies Press, 2010. https://doi.org/10.17226/12840

7 Ann Gadzikowski. "Planting the Seeds of Computational Thinking in Early Childhood.",2019. http://anngadzikowski.com/planting-the-seeds-of-computational-thinking-in-earlychildhood/ 
készitését, a következtetések levonását és más problémamegoldást célzó gondolkodási folyamatok tervezését.

Összegzésként kijelenthetjük, hogy az informatikai gondolkodás az 1950-es években kialakult felfogáshoz képest jelentős tartalombővülésen ment keresztül az elmúlt évtizedekben, hiszen a számítástudományi gyökerektől elindulva napjainkra egy átfogóbb, az egyén információ feldolgozása közben végbemenő kognitiv és metakognitiv folyamatokra fókuszáló, összetett fogalmat értünk alatta. ${ }^{8}$ A CT tehát azonban a programozással, hiszen ez egy funkcionális gondolkodási alap(készség), amelyben az egyén gondolkodásmódja legyen az elötérben, nem pedig az, ahogyan a gépek gondolkodnak.

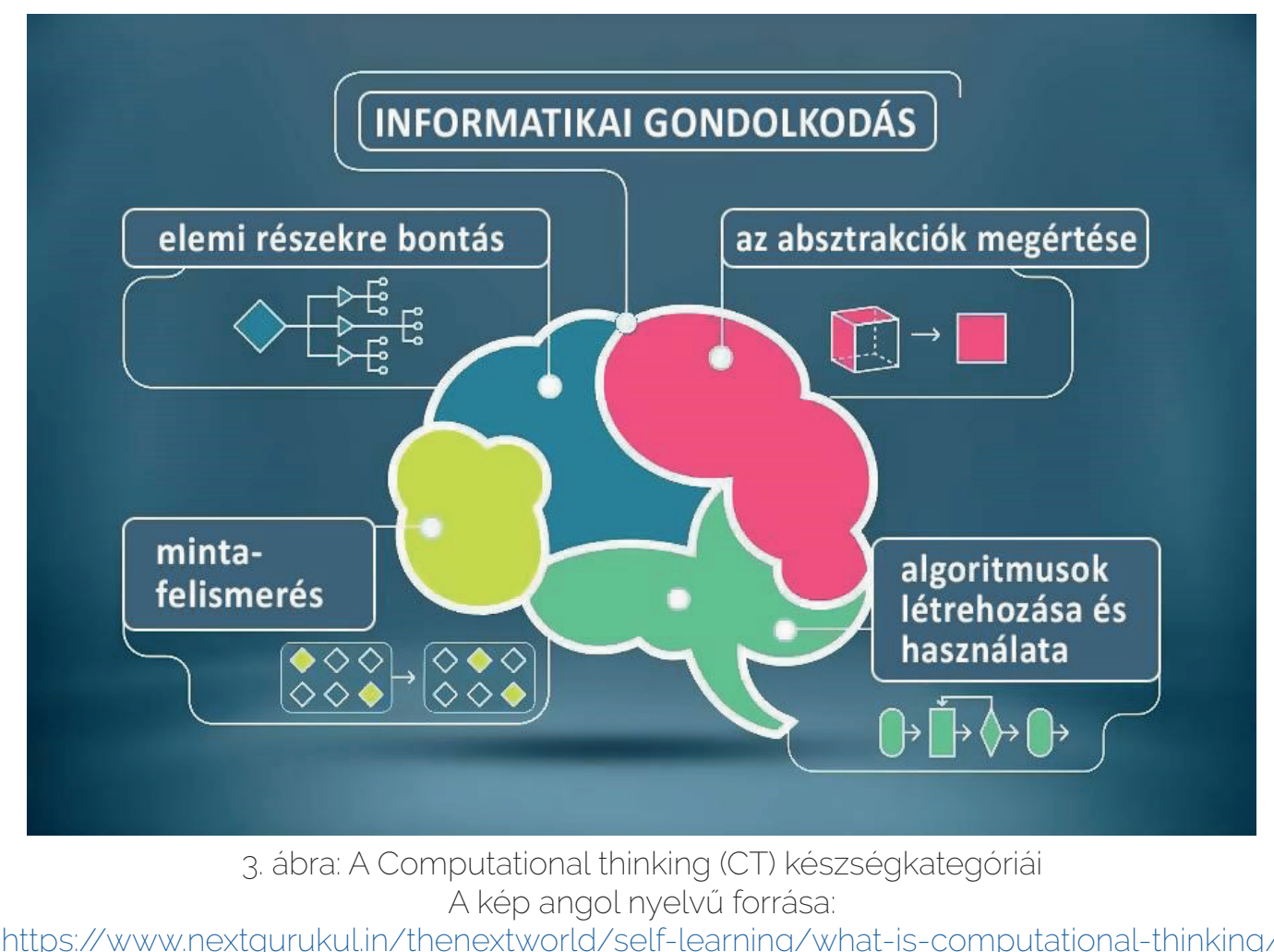

Az informatikai gondolkodás alatt problémák elemeiegységekre történő felbontását értjük, a minták megfigyelését és tendenciák felismerését, a problémamegoldás lépéseinek meghatározását, valamint az absztrakciót, azaz a részletekröl történő elvonatkoztatást, a releváns információkra koncentrálást. E fogalom tehát ötvözi és kiegésziti a matematikai és mérnöki gondolkodást, tartalmazva azon mentális eszközöket, amelyekaszámitógép-tudományterületén használatosszakkifejezések széles skáláját tükrözik. ${ }^{9}$ 
A Computational Thinking (CT) tehát ernyőfogalomként hatja át a STEM egyes területeit, hiszen részei többek között az algoritmikus gondolkodás, a problémamegoldás, a programozás oktatása és a szimulációs játékok alkalmazása, szoros kapcsolatot mutatva az információs müveltséggel és a digitális kompetenciával.

\section{A Computational Thinking fogalmának megjelenése a DigComp 2.1-ben}

Napjainkban a digitális kompetencia nemcsak az IKT-hoz való hozzáférést és használatát jelenti, hanem magában foglalja a szükséges ismeretek, készségek és attitüdök birtoklását is.

A 2013-ban megjelent DigComp 1.0 (DIGCOMP: A Framework for Developing and Understanding Digital Competence in Europe) öt kompetenciaterületet jelölt meg: információ, kommunikáció, tartalomkészités, biztonság, problémamegoldás. ${ }^{10}$

A tanulmányban beazonositásra kerültek a digitális állampolgárság komponensei is, amelyet 21 kompetenciaelemre bontottak.

A DigComp 2.0 (DigComp 2.0: The Digital Competence Framework for Citizens. Update Phase 1: the Conceptual Reference Model) az elsö keretrendszert további elemekkel bővitette, illetve kitért a kompetenciaelemekben való jártasság szintjeire is. ${ }^{11}$

A cikk írásakor a legfrissebb, 2017-ben megjelent DigComp 2.1 (DigComp 2.1: The Digital Competence Framework for Citizens with eight proficiency levels and examples of use) nyolc jártassági szintet és példát mutat be a tanulás és a foglalkoztatás területein. ${ }^{12}$

Az European Commission weboldalán megtalálható az Európai Unió saját definíciója a Computational Thinking-röl, miszerint: az informatikai gondolkodás egy „számítógépes tudósként” való gondolkodás röviditése, vagyis a számítógépes

$10 \quad$ Ferrari, Anusca. "DIGCOMP: A Framework for Developing and Understanding Digital Competence in Europe." Luxembourg, Sweden: Joint Research Centre of the European Commission, 2013. http://publications.jpc.ec.europa.eu/repository/bitstream/JRC83167/lbna-26035-enn.pdf

11 Riina Vuorikari, Yves Punie, Stephanie Carretero, Lieve Van den Brande. "DigComp 2.o: The Digital Competence Framework for Citizens. Update Phase 1: the Conceptual Reference Model." Luxembourg, Sweden: Joint Research Centre of the European Commission, 2016. http://publications.jrc.ec.europa.eu/repository/bitstream/JRC101254/jrc101254_digcomp\%20 2.0\%20the\%20digital\%20competence\%20framework\%20for\%20citizens.\%20update\%20 phase\%201.pdf

12 Stephanie Carretero, Riina Vuorikari, Yves Punie. "DigComp 2.1: The Digital Competence Framework for Citizens with eight proficiency levels and examples of use." Luxembourg. Sweden: Joint Research Centre of the European Commission, 2017. http://publications.jrc.ec.europa.eu/repository/bitstream/JRC106281/web-digcomp2.1pdf_. (online).pdf 
Az informatikai gondolkodás (computational thinking) fogalmi keretei

tudomány fogalmának használata a problémák megfogalmazásához és megoldásához."13

\section{A kutatás folytatása}

E munka egy előkészitő szakaszt képez a további elemzésekhez, amelyben a hazai helyzetet vizsgálnám meg, olyan tekintetben, hogy az oktatásirányítási dokumentumokban (MDOS, 2016; NAT 2018) hogyan jelenik meg e fogalom, valamint annak elemei.

A kutatásom következő fázisában egy attitüdkutatásra kerül sor, amely során az informatikai gondolkodással kapcsolatos vélekedéseket vizsgálnám meg, kombinált paradigma módszerével (Sántha, 2014) a pedagógusképzésben, egy saját fejlesztésü méröeszközzel, kérdőiv, majd interjú formájában.

\section{Irodalom}

Ann Gadzikowski. "Planting the Seeds of Computational Thinking in Early Childhood.",2019.

http://anngadzikowski.com/planting-the-seeds-of-computational-thinking-inearly-childhood/

Digital Economy and Society Index 2018 - Magyarország.

http://europa.eu/rapid/press-release_MEMO-18-3737_en.htm

European Commission. https://ec.europa.eu/jrc/en/computational-thinking

Ferrari, Anusca. "DIGCOMP: A Framework for Developing and Understanding Digital Competence in Europe." Luxembourg, Sweden: Joint Research Centre of the European Commission, 2013. http://publications.jrc.ec.europa.eu/repository/ bitstream/JRC83167/lb-na-26035-enn.pdf

Jan Cuny, Larry Snyder, and Jeannette M. Wing. "Demystifying Computational Thinking for Non-Computer Scientists" work in progress, 2010.

Jeannette M. Wing. "Research Notebook: Computational Thinking - What and Why? The Link." Pittsburgh, PA: Carneige Mellon, 2011.

https://www.cs.cmu.edu/\%7ECompThink/resources/TheLinkWing.pdf

Jeannette M. Wing. "Computational Thinking," Communications of the Association for Computing Machinery Viewpoint, March 2006, pp. 33-35.

http://www.cs.cmu.edu/ ./15110-s13/Wingo6-ct.pdf

Kampylis, P., Punie, Y. "The Computational Thinking Study." EU Science Hub, 2016. https://ec.europa.eu/jrc/en/computational-thinking

13 Kampylis, P., Punie, Y. "The Computational Thinking Study." EU Science Hub, 2016. https://ec.europa.eu/irc/en/computational-thinking 
National Research Council. "Report of a Workshop on the Scope and Nature of Computational Thinking." Washington, DC: The National Academies Press, 2010. https://doi.org/10.17226/12840

Pluhár Zsuzsa. "Az informatikai gondolkodás és a hód." InfoDidac2016 Módszertani konferencia, 2016.

https://people.inf.elte.hu/szlavi/InfoDidact16/Manuscripts/PZs_Hod.pdf

Pluhár, Zsuzsa és Torma, Hajnalka és Törley, Gábor. "Hallgatói teljesítményértékelés az algoritmikus gondolkodás tükrében." In: InfoDidact 2018. Webdidaktika Alapitvány, Budapest, pp. 1-10., 2019. http://real.mtak.hu/92129/

Racsko Réka. "Digitális átállás az oktatásban." Gondolat Kiadó, Veszprém. Iskolakultúra-könyvek 52., 2017.

http://misc.bibl.u-szeged.hu/46196/1/iskolakultura_konyvek_052.pdf

Riina Vuorikari, Yves Punie, Stephanie Carretero, Lieve Van den Brande. "DigComp 2.0: The Digital Competence Framework for Citizens. Update Phase 1: the Conceptual Reference Model." Luxembourg, Sweden: Joint Research Centre of the European Commission, 2016.

http://publications.jrc.ec.europa.eu/repository/bitstream/JRC101254/jrc101254_ digcomp $\% 202.0 \% 20$ the $\% 20$ digital\%20competence $\% 20$ framework $\% 20$ for $\% 20$ citizens.\%20update\%20phase\%201.pdf

Romero, M., Lepage, A. \& Lille, B. "Computational thinking development through creative programming in higher education.", 2017.

https://doi.org/10.1186/s41239-017-0080-z

Selby C. "Computational Thinking: The Developing Defenition." Submitted for ItiCSE Conference 2013. http://people.cs.vt.edu/\%7Ekafura/CS6604/Papers/CTDeveloping-Definition.pdf

Stephanie Carretero, Riina Vuorikari, Yves Punie. "DigComp 2.1: The Digital Competence Framework for Citizens with eight proficiency levels and examples of use." Luxembourg, Sweden: Joint Research Centre of the European Commission, 2017.

http://publications.jrc.ec.europa.eu/repository/bitstream/JRC106281/webdigcomp2.1pdf_(online).pdf

Szegedi Eszter. "Miért került világszerte fókuszba a STEM területek oktatása?" pp. 9-14., 2014. http://tka.hu/docs/palyazatok/belestem.pdf 


\title{
A felhasználói viselkedés, mint információbiztonsági kockázat becslése
}

\author{
Leitold Ferenc \\ Secudit Kft. \\ fleitold@secudit.com
}

\begin{abstract}
A felhasználói viselkedés sokkalveszélyesebbé teszi egy szervezet müködését, mint bármely technikai sebezhetőség. Számos technikai megoldás létezik a technikai lehetőségeket kihasználó támadásokkal szemben. Az informatikai biztonság technikailag egy jól felkészült védelmet képes biztositani, ugyanakkor az emberi tényező kezelése még mindig a gyerekcipöben jár. Ez az elöadás a felhasználói viselkedés értékelésének lehetséges módszereivel foglalkozik, alapvetően néhány hasznos megfigyelési lehetőség kerül előtérbe, melyek alkalmasak (akár automatikus módon) a felhasználói viselkedés mérésére. A bemeneti források, amiket használhatunk, az adott felhasználó által használt munkaállomásból, a hálózati forgalomból és az alkalmazásnaplókból (különösen a védelmi rendszerek naplóiból) származhatnak. Ezeket a bemeneti forrásokat használva néhány nagyon hasznos metrikát is definiálhatunk a felhasználók viselkedésének megitéléséhez, illetve a felhasználók besorolásához. Miután meg tudtuk mérni a felhasználói magatartás szintjét, használhatjuk azt az adott szervezet informatikai biztonságának javítására is.

A tanulmány a következő részeket tartalmazza:

- Bevezetés a felhasználói viselkedés kezelésébe (mérés és cselekvés),

- Hasznos eszközök a felhasználók viselkedésével kapcsolatos néhány alapvető jel automatikus méréséhez,

- A mért adatok kiszámítása a mért jelekből,

- Mit tehetünk a metrikákkal?
\end{abstract}

Keywords: vulnerability assessment, user behavior assessment, human factor

\section{Bevezetés}

A DVA (Distributed Vulnerability Assessment) technológia a Dunaújvárosi Egyetem és a Secudit közös kutatási munkája alapján jött létre. A DVA részletes leírást ad egy szervezet internetes támadási sebezhetőségeiről. A módszer szerint első lépésként az egyedi felhasználók és az informatikai infrastruktúra elemeinek sebezhetőségét az egyes ismert fenyegetésekre vonatkozóan kell felmérni, majd ezeket az eredményeket kombinálni az adott szervezet számára releváns fenyegetésekre vonatkozóan. A módszer egy adott szervezet integrált kibertámadási sebezhetőségét a jelenleg ismert fenyegetések elterjedtségét és hatékonyságát; a felhasználók biztonságtudatos viselkedését; és az informatikai infrastruktúra gyengeségeit alapul véve értékeli. Matematikai módszereket alkalmazva az integrált sebezhetőség felbontható arra, hogy az egyes felhasználók, illetve az egyes IT infrastruktúra elemek milyen mértékben járulnak hozzá az integrált sebezhetőséghez, a teljes szervezet fenyegetettségéhez. A DVAeredményekböl a fenyegetettség mennyiségi szempontból hozzárendelhet a 
különböző belső hozzájáruló összetevökhöz (például felhasználói azonosító, portok, protokollok, védelmi rétegek). Ez lehetővé teszi, hogy különböző közremüködő komponenseket összehasonlitható méröszámokkal értékeljünk (pl. felhasználói biztonságossági tudatosság, az infrastruktúra javitásának lehetösége, illetve a rosszindulatú programok elleni védelem hatékonysága alapján). A DVA lehetövé teszi az információbiztonsági menedzserek számára, hogy a "mi lenne, ha" típusú lekérdezések eredményei alapján összehasonlithassák a különböző rendelkezésre álló lehetöségeket a szervezet fenyegetettségének csökkentése érdekében, amelyek egyébként nem lennének mennyiségi szempontból összehasonlithatók (pl. további cybersecurity alkalmazások és szolgáltatások.)

A DVA módszer müködésének alapfeltétele, hogy a felhasználói biztonságtudatosságot is automatikusan lehessen mérni. Ebben a cikkben a felhasználói biztonságtudatosságra jellemző metrikával foglalkozunk, milyen jellemzők alapján mérhetö.

\section{Fenyegetettségek modellezése}

Ahhoz, hogy egy kártékony támadás sikeres legyen egy védett hálózattal szemben, a kártékonykód sikeresvégrehajtásaszükséges. Afelhasználóioldalonalegegyszerübb minimális viselkedés nem más, mint a végpont eszköznek az internethez történö csatlakoztatása. Az informatikai biztonsági metrikák manapság a védett IT-re (pl. folyamatos sérülékenység-tesztelés), illetve a kártevök tevékenységére, tulajdonságaira (pl. védelmi rendszerek tesztelése) [6] fókuszálnak. A felhasználói magatartásra vonatkozó informatikai biztonsági metrika kevésbé fejlett [3], habár a hálózati forgalom megfigyelése lehetöséget ad a fejlesztésükre (pl. NetFlow/IPFIX). A passziv figyelés mellett az interaktiv metrikát is alkalmazhatjuk [10].

A sikeres kártékony támadásokat a védett környezetben megvalósitható kártékony tevékenység és a megfelelő felhasználói magatartás metszeteként lehet reprezentálni. Ez a koncepcionális keret az NSS Lab által használt müködési szabályokra épül [18], ugyanakkor praktikus és kényelmes egyszerüsítése a támadási felületek komplett kezelésének. Az alábbiakban csak a humán-interaktív végpontokra fókuszálunk (IT), a beágyazott rendszerek biztonsági architektúrájával (IoT, OT) jelenleg nem foglalkozunk. Három különálló, de erősen interaktív sérülékenységi forrást veszünk figyelembe:

(1) kártékony tevékenység azok által, akik saját céljaikra használják ki a hálózat képességeit, hogy megsértsék a megbízható IT rendszer védelmét;

(2) veszélyes IT felhasználói magatartás (pl. alkalmazottak, vevők, beszállitók); és

(3) védelem nélküli sérülékenység az IT hálózati infrastruktúrában.

A legkritikusabb sérülékenység e három terület közös részében, metszetében található (1. ábra). E sérülékenységek megfelelö láthatóságot, ellenörzést és megkülönböztetést követelnek a megfigyelésükhöz, megértésükhöz és az ellenük történő hatékony védekezéshez. A meglevő és esetleg felmerülő sérülékenységek láthatóságához éber 


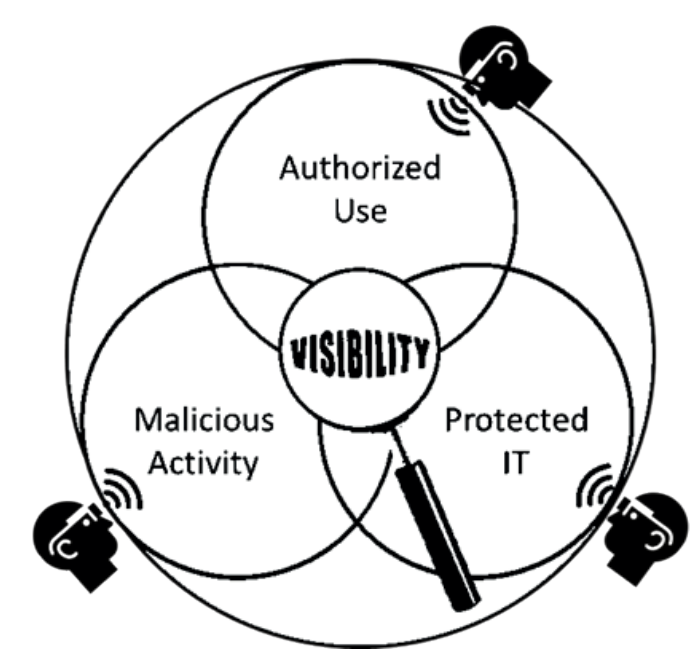

1. ábra: Az IT sérülékenység komponenseit és tényezőit három területre lehet osztani, melyek mindegyikének saját módszere és eszközei vannak a láthatóság, ellenörzés és megkülönböztetés céljára [13]

kockázatelemzés szükséges, ami mindhárom területet figyeli (1. ábra).

Az információs folyamatok sérülékenységeinek láthatósága szükséges, de önmagában elégtelen az informatikai biztonság szempontjából. A sérülékenység értékelése a biztonság biztositásának legkülsőbb rétege. A következő rétegek: sérülékenység érzékelés, sérülékenység javítása, biztonsági incidensre való felkészülés, biztonsági incidens érzékelése, és biztonsági incidensre való reagálás (2. ábra).

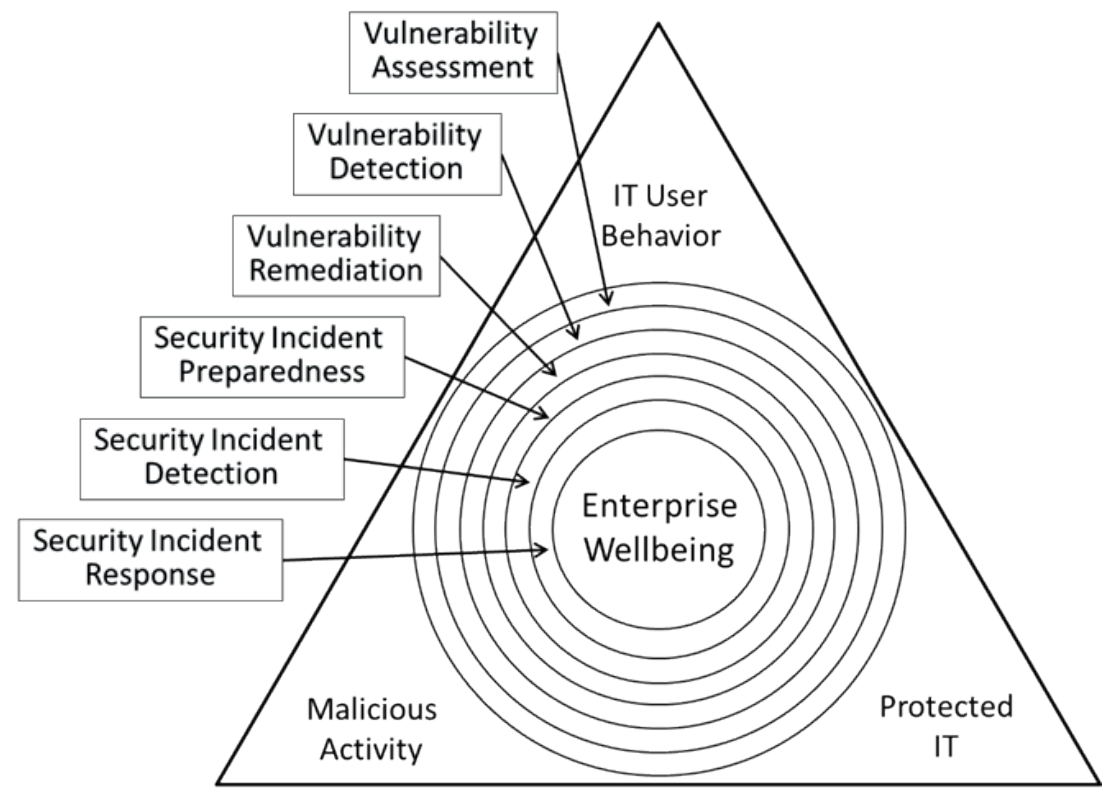

2. ábra: Sérülékenység felmérése a teljes biztonság érdekében a szervezet jóléte céljából [13]

Aszervezetjólétének biztosításáhoza sérülékenységek kezelése a sérülékenységek forrásainak gyakorlati és hatékony azonosítását követeli meg. A biztonsági incidensre való reagálás követelményét az esemény információkezelő rendszerek elégítik ki (SIEM). A sérülékenységek hatékony kezeléséhez az informatikai sérülékenység 
hármas modellje szükséges. A korábbi szabályokból eredően [11, 12] a hármas modell a sérülékenység mérését 3 forrásra osztja: i) kártékony tevékenység; ii) védelemmel rendelkező IT; és iii) nem megfelelő felhasználói magatartás. Mindegyik forrásban specifikus tényezöket azonositunk és jellemzünk (pl. vírusküldés és kihasználás a kártékony tevékenységi hármasban). A modell alapot ad a tényezők korrelációjához és kombinálásához a sérülékenységek integrált nézetéhez.

\section{A DVA számításának matematikai háttere}

Az elosztott fenyegetettség felmérés (DVA) matematikai háttere valószínüségszámításra épül ([19]):

Legyen

$$
\mu(t, u)=\frac{\text { number of attempts of } \boldsymbol{t} \text { are enabled by the user } \boldsymbol{u}}{\text { number of attempts of } \boldsymbol{t} \text { are enabled by the average user }}
$$

Ekkor

$$
p_{s}(l)=1-\prod_{\text {for all } t, u \text { and } i}\left(1-p_{\text {user }}(t, u) \cdot p_{\text {device }}(t, i) \cdot p_{\text {prev }}(t, l)\right)^{k(t, u)}
$$

ahol $u \in U, i \in I, t \in T_{l}, l \in L$ és

$$
k(t, u)=\frac{T}{\Delta T} \cdot \frac{T_{u}}{T_{\text {average }}} \cdot \mu(t, u)
$$

ahol

$\Delta T$ az elterjedtségekre (prevalence) vonatkozó időintervallum,

T az az időintervallum, amire az általunk számított valószinüségi mérték vonatkozik,

$T_{u}$ az az időintervallum, amennyi ideig az u felhasználó használja a számítógépet,

$T_{\text {average }}$ az az időintervallum, amennyi ideig egy átlagos felhasználó használja a számitógépet, $\mu(t, u)$ a fentiek alapján számított érték. 
A fenti képletben a felhasználói viselkedés az alábbi tényezőkben jelenik meg:

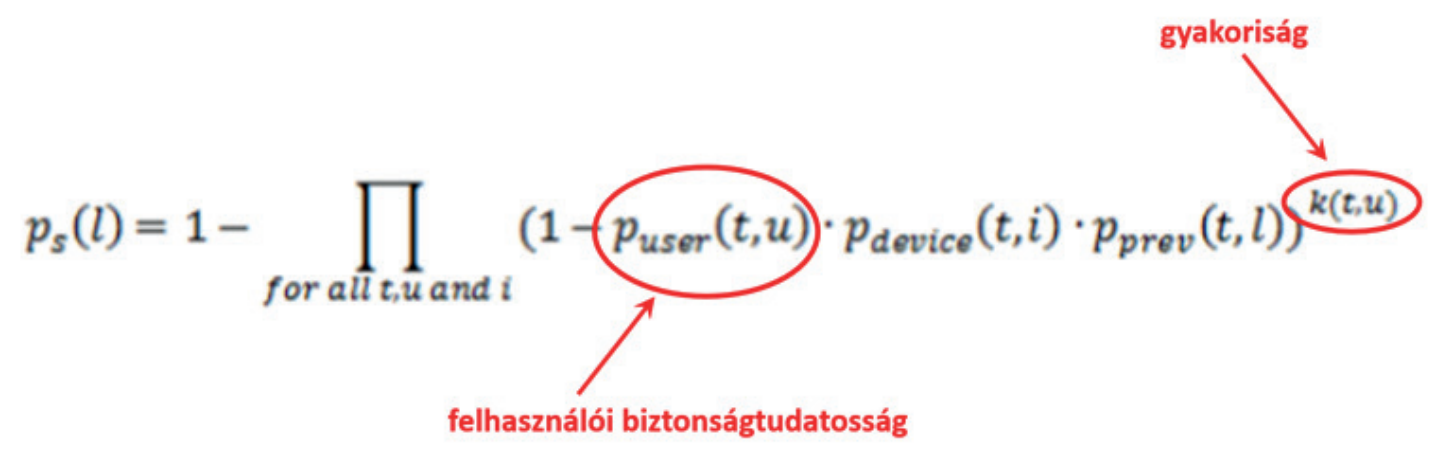

A DVA modell szerint a felhasználói viselkedés két tényező formájában jelenik meg, egy számítógép felhasználónak két lényeges tulajdonsága van, melyek befolyásolják a szervezet veszélyeztetettségi mértékét. Egyrészt a felhasználói biztonságtudatoságra jellemző mérték, mely azt mondja meg, hogy egy adott felhasználó esetén, ha egy bizonyos szítuációba kerül milyen valószinüséggel hoz olyan döntést vagy végez olyan tevékenységet, mely aztán a veszély okozta esemény bekövetkezését eredményezi. A másikjellemző tulajdonság arra utal, hogy egy adott felhasználó milyen gyakran kerül olyan szituációba, hogy döntést kelljen hoznia. Ez útóbbi esetben rengeteg olyan eszköz, szolgáltatás áll rendelkezésre, mely képes arra, hogy például a felhasználók be- és kijelentkezési idejét, a szoftverek használatát naplózza. Ebben a cikkben a továbbiakban elsősorban a felhasználói biztonságtudatossággal, annak mérésével, illetve a felhasználói biztonságtudatossági mérték meghatározásával foglalkozunk.

\section{Felhasználói biztonságtudatosság mérése}

A felhasználói biztonságtudatosság esetén két lényeges kérdés merül fel: egyrészt azt vizsgáljuk meg, hogy melyek azok a mérhető jelek, melyek szoros kapcsolatban vannak a biztonságtudatossággal, illetve a mérési módszer lehetöségeit is megvizsgáljuk.

\section{Mit mérhetünk?}

A felhasználói biztonságtudatosság esetén számos olyan mérhető információ áll rendelkezésre, melyek segithetnek a felhasználói biztonságtudatosságra jellemző mérték meghatározásában. Ilyenek például:

- Eszköz használata

- Alkalmazások használata (föként: kommunikációs alkalmazások)

- Különbözö típusú fájlok megnyitása/inditása

- Védelmek befolyásolása (pl.: frissités, felfüggesztés)

- Böngészés az interneten

\section{Hogyan mérhetünk?}

A felhasználói biztonságtudatosság mérésére manuális, kérdőiv, tesztjellegü felmérés az általában megszokott módszer. Ennek a legnagyobb hátránya, hogy nem a tényleges viselkedés biztonságosságát méri, hanem azt, hogy a felhasználó 
milyen biztonságtudatossági ismeretekkel rendelkezik. Azaz a mérés hibás lesz azokra vonatkozóan, akik pontosan tudják, hogy mi a helyes, biztonságtudatos viselkedés, de nem azt teszik.

A biztonságtudatosság mérése alapvetően két módszerrel képzelhető el:

- A passzív módszer révén a felhasználók szokásos viselkedését vizsgáljuk és ebben keresünk olyan jeleket, amelyek olyan magatartásra utalnak, amelyek valamilyen veszély/támadás elhárítását vagy elősegítését jelentik.

- Az aktív módszer segitségével szándékosan elöidézünk olyan szituációkat, melyekkel valamely veszély/támadás esetén a felhasználói döntést szimuláljuk. Ebben az esetben a felhasználók szokásos viselkedése helyett a felhasználók elöidézett szituációkban történö döntését.

Mind a passziv, mind az aktiv módszernek megvannak az előnyei és hátrányai. Passzív módszer esetén a felmérés semmilyen módon nem akadályozza a szervezet szokásos müködését, míg az aktív módszer esetén ez nem igaz. Az aktív módszer viszont különböző típusú szituációkra vonatkozóan képes a mérést elvégezni, míg a passziv esetben csak olyan szituációk esetén történik ez meg, amelyek ténylegesen elöfordulnak.

\section{Felhasználói esetek}

Amennyiben a felhasználók biztonságtudatos viselkedéséhez valamilyen mérőszámot szeretnénk hozzárendelni, alapvető, hogy ez a méröszám lehetőséget adjon az összehasonlitásra. Az alábbiakban ennek fényében három egyszerü esetet vizsgálunk.

\section{I. eset}

Az első esetben a különbözö böngészési szokások oldaláról közelítjük meg a felhasználói biztonságtudatosságot. Adott egy felhasználó, aki minden munkanap a böngészöben csak a www.port.hu és a www.idokep.hu oldalakat nyitja meg. Egy másik felhasználó pedig a böngészőjében minden héten legalább 20 olyan weboldalat nyit meg, amit nem látogatott az elmúlt 6 hónapban. Minden egyéb vonatkozásban a két felhasználó viselkedése azonos. Ebben az esetben azt mondhatjuk, hogy a második felhasználó nyilván nagyobb veszélyt jelent, azaz jobban hozzájárul a szervezet veszélyeztetettségi szintjéhez.

\section{II. eset}

A második esetben azt mutatjuk meg, hogy akár különböző munkahelyi feladatkörök is befolyásolják a felhasználói biztonságtudatosságot. Adott egy felhasználó, aki a HR osztályon dolgozva, fogadja az álláspályázatokat email-ben és munkaköri feladata, hogy megnyissa a bennük lévő PDF csatolmányokban lévő önéletrajzokat. Egy másik felhasználó pedig soha nem kapott olyan email-t, amiben PDF melléklet lett volna. Minden egyéb vonatkozásban a két felhasználó viselkedése azonos. Ebben az esetben azt mondhatjuk, hogy az első felhasználó nyilván nagyobb veszélyt jelent, azaz jobban, azaz jobban hozzájárul a szervezet veszélyeztetettségi szintjéhez. Ez tehát nem abból adódik, hogy az információbiztonsági tudása alacsonyabb lenne, csupán a munkahelyi feladatköre jelenti a nagyobb kockázatot. 


\section{III. eset}

A harmadik esetben az első és a második esetet egyesitjük. Adott egy felhasználó, aki a HR osztályon dolgozva, fogadja az álláspályázatokat email-ben és munkaköri feladata, hogy megnyissa a bennük lévő PDF csatolmányokban lévö önéletrajzokat, ugyanakkor a böngészöben csak a www.port.hu és a www.idokep.hu oldalakat nyitja meg. Egy másik felhasználó pedig soha nem kapott olyan email-t, amiben PDF melléklet lett volna, ugyanakkor a böngészőjében minden héten legalább 20 olyan weboldalat nyit meg, amit nem látogatott az elmúlt 6 hónapban. Minden egyéb vonatkozásban a két felhasználó viselkedése azonos. Ebben az esetben nem tudjuk egyértelmüen megállapitani, hogy melyik felhasználó jelent nagyobb veszélyt a szervezet számára. Ezt akkor tudnánk megtenni, ha ismerjük azokat a veszélyforrásokat, amelyek emailben, PDF csatolmányokban terjednek, illetve azokat a veszélyforrásokat, amelyek a böngészési szokásokra épitenek.

\section{5. Összegzés}

A fentiekben módszert mutattunk be a sérülékenység mérésére. Három információforrást használunk: külső informatikai fenyegetés intelligencia („biztonsági intelligencia”), szervezeti IT infrastruktúra gyengeség („behatolás tesztelés”), és a felhasználók fogékonysága, naivsága a támadásokra („felhasználói magatartás"). A módszer lehetövé teszi a mért források kombinálását egy metrikába, amit összevethető sérülékenységekre bonthatunk. A módszer számszerüsíti a relatív sérülékenység evolúcióját időben, külön mérheti az egyedi osztályok (LAN) sérülékenységét és a specifikus fenyegetéseket (pl. zsaroló vírusok, adathalászat). A módszer előrejelzi a potenciális javítási tevékenység következményeit („Mi lesz, ha?"), ezáltal segíti a biztonsággal kapcsolatos döntéshozatalt az adott helyzetben.

A programozott fenyegetések száma manapság 7-800 millió körüli, az aktív támadások köre folyamatosan változik, ráadásul a támadások kb. 90\%-át egyedi fertözések okozzák. Ilyen körülmények között az egy szervezetre vonatkozó veszélyeztetettség mérése sokkal inkább becslés, mint pontos számitás. A bemeneti adatok minél pontosabb meghatározásával, a figyelembe vett kártevők körének kiválasztásával pontosabbá tehető az analizis.

A módszer egyik legfontosabb összetevője a felhasználói viselkedés mérése. A 4. fejezetben leirtak szerint azonban a felhasználói biztonságtudatosság nem csupán egyfelhasználórajellemzőmetrika, hanemeztveszélyforrásonkéntkellmeghatározni az egyes felhasználók vonatkozásában. Ennek érdekében a viselkedésre vonatkozó jeleket, jelzéseket kell mérni, majd ezek segitségével határozhatjuk meg a különbözö támadási vektorok vonatkozásában a felhasználókra jellemző metrikákat. Minden, a felhasználók viselkedésére vonatkozó mérés természetszerüleg felveti a GDPR vonatkozását is. A GDPR szempontjából a felhasználói viselkedésre vonatkozó mérések, egy szervezet veszélyeztetettségi elörejelzése az információbiztonság javitásának az irányába tett lépésnek tekinthető és így a GDPR céljait szolgálja. Természetesen a GDPR-nak megfelelöen a módszer csakis az arányosság elvét szem előtt tartva és a felhasználók megfelelő tájékoztatásával alkalmazható. 


\section{Irodalom}

[1] ARROTT, A., F. Lalonde Levesque, D. Batchelder, and J.M. Fernandez. "Citizen cyber-security health metrics for Windows computers". Proceedings of Eastern European eGov Days Conference, EEGOV, Budapest, Hungary. 2016.

[2] BATCHELDER, D., et al. "Microsoft Security Intelligence Report." Volume 18: July-December 2014, Microsoft, 2015.

[3] CHAPMAN, M.T., "Establishing metrics to manage the human layer." ISSA Security Education Awareness Special Interest Group, 2013.

[4] CLEMENTI, Andreas, Peter Stelzhammer, and Fernando C. Colon Osorio. "Global and local prevalence weighting of missed attack sample impacts for endpoint security product comparative detection testing." Malicious and Unwanted Software: The Americas (MALWARE), 2014 9th International Conference on. IEEE, 2014.

[5] COLON OSORIO, F.C., and A. Arrott. "Fabric of security - changing our theory and expectations of modern security". Proceedings of Eastern European eGov Days Conference, EEGOV, Budapest, Hungary. 2016.

[6] EDWARDS, S.E., R. Ford, and G. Szappanos., "Effectively testing APT defenses". Virus Bulletin Conference, Prague, Czech Republic, 2015.

[7] KLEINER, A., P. Nicholas, K. Sullivan, "Linking Cybersecurity Policy and Performance, Microsoft Trustworthy Computing", 2013,

[8] KSHETRI, Nir. "Cybercrime and Cybersecurity in the Middle East and North African Economies." Cybercrime and Cybersecurity in the Global South. Palgrave Macmillan UK, 2013.

[9] LALONDE LEVESQUE, F., A. Somayaji, D. Batchelder, and J.M. Fernandez. "Measuring the health of antivirus ecosystems." Malicious and Unwanted Software (MALWARE), 2015 10th International Conference on. IEEE, 2015.

[10] LALONDE LEVESQUE, F., J. M. Fernandez, and A. Somayaji. "Risk prediction of malware victimization based on user behavior." Malicious and Unwanted Software: The Americas (MALWARE), 2014 9th International Conference on. IEEE, 2014.

[11] LEITOLD, F and K. Hadarics. "Measuring security risk in the cloud-enabled enterprise." Malicious and Unwanted Software (MALWARE), 7th International Conference on Malicious and Unwanted Software, pp: 62-66, ISBN: 978-1-46734880-5. 2012.

[12] LEITOLD, F. "Security Risk analysis using Markov Chain Model." 19th Annual EICAR Conference, Paris, France. 2010. 
[13] LEITOLD, F., A. ARROTT and K. HADARICS, "Quantifying cyber-threat vulnerability by combining threat intelligence, IT infrastructure weakness, and user susceptibility" 24th Annual EICAR Conference, Nuremberg, Germany, 2016

[14] LEITOLD, F., A. ARROTT and K. HADARICS, "Automating visibility into user behavior vulnerabilities to malware attack" Proceedings of the 26th Virus Bulletin International Conference (VB2016), pp. 16-24, Denver, USA, 2016.

[15] MICROSOFT. "Evolution of malware and the threat landscape - a 10-year review". 2012.

[16] MICROSOFT. "Malicious Software Removal Tool (MSRT)". Microsoft Knowledge Base, article KB890830 revision 161.2, https://support.microsoft.com/en-us/kb/890830

[17] RUBENKING N., "Why Microsoft Doesn't Need Independent Antivirus Lab Tests". PC Magazine, 28 October 2013.

[18] SHAH P, Phatak V, Scipioni R, inventors. "Adaptive intrusion detection system." United States patent application US 10/443,568. 2003 May 22.

[19] LEITOLD, Fand K. Hadarics. "Elosztott fenyegetettség felmérés" Networkshop Konferencia, Eger, 2018. 